\title{
REVISIONES DELA
}

\section{LITERATURA PARAGUAYA}

Coordinado por

MAR LANGA PIZARRO y JOSÉ VICENTE PEIRÓ BARCO

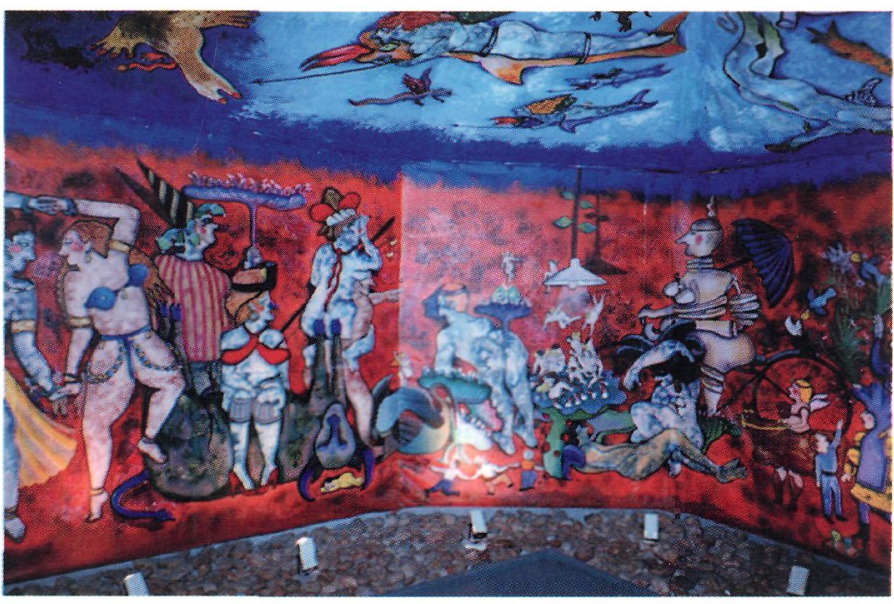

José Carlos Rovira
José Antonio Alonso
Maria Gabriella Dionisi
Francisco Doratioto
Hugo Duarte
Renée Ferrer
Ronald Haladyna
Sara Karlik
Mar Langa Pizarro
Wolf Lusting
Reni Marchevska
Teresa Méndez-Faith
Jose Vicente Peiró
Edda de los Rios
Sonja Steckbauer
Paco Tovar
Rubén Bareiro Saguier

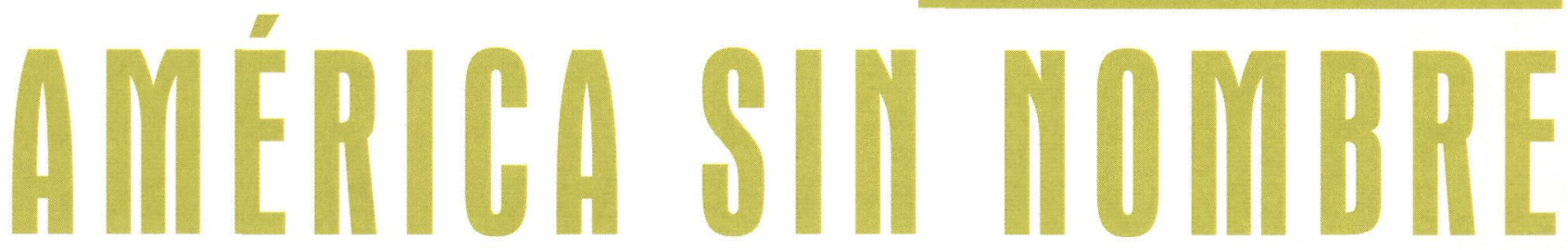

- Boletín de la Unidad de Investigación de la Universidad de Alicante: «Recuperaciones

$\stackrel{\circ}{Z}$ del mundo precolombino y colonial en el siglo $X X$ hispanoamericano» 
AMÉRICA SIN NOMBRE es el Boletín de la Unidad de Investigación de la Universidad de Alicante «Recuperaciones del mundo precolombino y colonial en el siglo XX hispanoamericano» (Proyectos MEC PB 98-0982 y MCYT BFF 2002-01058) y tendrá una periocidad de un número anual.

\section{AMÉRICA SIII NOMBBDE}

Boletín de la Unidad de Investigación de la Universidad de Alicante: «Recuperaciones del mundo precolombino y colonial en el siglo XX hispanoamericano»

$\mathrm{N}^{\circ}$ 4, diciembre de 2002

Director: José Carlos Rovira

Subdirectora: Carmen Alemany Bay

Secretaria: Remedios Mataix Azuar

\section{Consejo editorial:}

Beatriz Aracil Varón (UA, coordinadora)

Miguel Ángel Auladell Pérez (UA)

Eduardo Becerra Grande (Universidad Autónoma

de Madrid)

Teodosio Fernández Rodríguez (Universidad.

Autónoma de Madrid)

Virginia Gil Amate (Universidad de Oviedo)

Aurelio González (El Colegio de México)

Rosa Maria Grillo (Universidad de Salerno)

Ramón Lloréns García (UA)

Francisco José López Alfonso (UV)

Sonia Mattalía (UV)

María Águeda Méndez (El Colegio de México)

Kiko Mora Contreras (UA)

Ramiro Muñoz Haedo (UA)

Nelson Osorio Tejeda (Universidad de Santiago de Chile)

Ángel Luis Prieto de Paula (UA)

Francisco Tovar Blanco (Universitat de Lleida-

Estudi General)

Eva Valero Juan (Universidad Autónoma de Madrid)

\section{Colaboradores:}

Claudia Comes Peña

Mónica García Irles

David García Vergara

Pedro Mendiola Oñate

Francisco Mollá Ruiz

Elena Pellús Pérez

Rafael Sellers Espasa

Paola Madrid Moctezuma

Este boletín está asociado a la actividad del CENT'RO DE ESTUDIOS IBEROAMERICANOS «MARIO BENEDETTI»

ISSN: $1577-3442$

Depósito Legal: MU-2335-1999 


\section{AMÉRICA SIII HOMBPBE \\ sumario}

José Carlos Rovira 3 Editorial: Revisiones de la literatura paraguaya

José Antonio Alonso Navarro 5 Historia e intrahistoria en Donde ladrón no llega de Luis Hernáez

María Gabriella Dionisi 12 El elemento musical en la obra de Renée Ferrer

Fco. F. Monteoliva Doratioto 18 El nacionalismo lopizta paraguayo

Hugo Duarte Manzoni $23 \quad$ La condición editorial

Renée Ferrer 28 La liberación de la mujer a través de la escritura

Ronald Haladyna 35 Dos extremos de la poesía paraguaya: Carlos Villagra Marsal y Joaquín Morales

Sara Karlik $42 \quad$ El puntillismo narrativo en la obra de Gabriel Casaccia

Mar Langa Pizarro 47 El novelista paraguayo como re-escritor de la Historia

Wolf Lustig $54 \quad$ Literatura paraguaya en guaraní

Reni Marcherska 62 Una mirada hacia Los nudos del silencio de Renée Ferrer

Teresa Méndez-Faith 66 Núcleos temáticos recurrentes en la narrativa paraguaya del último cuarto de siglo

José Vicente Peiró Barco 72 Literatura paraguaya actual: poesía y teatro

Edda de los Ríos 81 Dos décadas de teatro independiente en Paraguay

Sonja M. Steckbaner $86 \quad$ Raquel Saguier: ficción autorreflexiva y sociocrítica en busca del amor

Paco Tovar 91 Ecos lorquianos en la memoria poética del Paraguay: Josefina Pla, Augusto Roa Bastos y Hérib Campos Cervera

Rubén Bareiro Saguier 102 Epílogo 


\title{
AMÉRRCA SIII IOMMBRE
}

\section{Revisiones de la literatura paraguaya}

\author{
José Carlos Rovira
}

Mar Langa y José Vicente Peiró me propusieron hace poco más de un año que dedicáramos un número de esta revista a la Literatura Paraguaya. Los dos forman parte de la Unidad de investigación de la que esta revista, América sin nombre, es portavoz, y los dos son doctores cuyas Tesis versaron sobre autores, novelas y movimientos de la literatura contemporánea en aquel país, habiendo tenido yo la fortuna, como director en un caso y juzgador en otro, de no haber estado lejos de las mismas. Con Peiró tuve además la satisfacción de colaborar, aunque fuera mínimamente, en la creación de un «Portal de Literatura Paraguaya» en la «Biblioteca Virtual Miguel de Cervantes» de la Universidad de Alicante.

La propuesta que me hicieron adquiere su sentido cuando un número importante de especialistas, críticos y creadores de varias geografías, pero principalmente del país al que nos dedicamos esta vez, dinamizan en estas páginas lo que con seguridad es una nueva visión de aspectos de la literatura contemporánea en Paraguay.

Como lector, e incluso una vez como viajero, he tenido una inquietud extraña ante ese país, del que durante muchos años tuve las mínimas coordenadas vivenciales y culturales: una vez conocí el alto significado cultural de Rafael Barret y El dolor paraguayo (incluso la polémica que el dolor creaba frente al «idilismo paraguayo» que el español Martín de Goicoechea Menéndez sustentaba allí a fines del siglo XIX); otra vez, en un tiempo imprescindible, conocí ampliamente la obra y la persona del más universal de sus escritores, Augusto Roa Bastos, que ha oscurecido involuntariamente con su preminencia literaria la visión que desde Europa podíamos tener sobre un tiempo difícil en el que otros escritores, entre dictaduras interminables y miserias sociales inacabadas, escribían, publicaban, intentaban ver la luz; hace algunos años conocí y leí a una de sus figuras poéticas más sobresalientes, Elvio Romero, con el que algún tiempo hernandiano y algunos encuentros en Alicante o Buenos Aires marcaron un sello indeleble de aprecio y amistad. Y leíamos inevitablemente algo de Josefina Pla, y algo de Hérib Campos Cervera, y luego, un poco más tarde, por indicación ya de los coordinadores de este número, a Gabriel Casaccia, a Guido Rodríguez Alcalá, a Renée Ferrer, a Raquel Saguier, a Rubén Bareiro... hasta empezar a 
descubrir - nos lo revelan sobre todo las páginas que siguen - una literatura que, probablemente en la reinterpretación de la propia historia y la propia cultura, está adquiriendo un nivel de igualdad con las otras literaturas que son exponentes universales de América Latina.

Las sensaciones de un viajero en Paraguay allá por 1995, cuando el país empezaba a salir de la violenta y larguísima dictadura de Strossner (de la que no acaba todavía de salir aunque no esté el dictador), son de caminos de tierra interminables por el desierto de El Chaco para llegar a la colonia Boquerón y realizar un vídeo, de búsquedas de ingenios azucareros y de pueblos perdidos como Iturbe, de encuentros con amigos en la noche de Asunción, con su tristeza y su risa superviviente.

Nos gustaría que América sin nombre sirviera esta vez para testificar una verdad y ser útil a la misma: la desdichada historia contemporánea, el mercado cultural y la pobreza social no nos deben hacer perder de vista que en Paraguay existe una gran literatura. $Y$ ésa es la evidencia de las páginas que honran hoy a esta revista. 
José Antonio Alonso Navarro es profesor de lengua y literatura inglesa y comparada en las Universidades Autónoma de Asunción y Evangélica del Paraguay respectivamente. Es también colaborador del Instituto Superior de Estudios Filosóficos y Humanísticos de los Jesuitas. Filólogo, escritor, y crítico literario especializado en literatura paraguaya es autor de los libros Blue Flood (1998); Paraguayan Pearls (1999); Sol y Luna (2000) en colaboración con el poeta paraguayo Ivân González; Llanto de Niño Gris (2001); y Yeruties de Terciopelo Negro y Rojo (2002). En estos momentos se halla preparando un libro de cuentos titulado Los cuentos del cangrejo paraguayo. Alonso tiene publicados hasta la fecha unos 90 artículos sobre literatura comparada. Hizo sus estudios de licenciatura y doctorado en la Universidad Complutense de Madrid (España); y en la Universidad de Knightsbridge (Inglaterra). Es miembro del SEP (Sociedad de Escritores del Paraguay).

\section{INTRODUCCIÓN}

En su novela Donde ladrón no llega (1996), Luis Hernáez no pretende reflejar detalladamente todo el complejo proceso histórico que llevó a la expulsión de los jesuitas en todos los territorios del vasto imperio español durante la época de la conquista, incluyendo Paraguay y otras tierras rioplantenses colindantes, en 1767, por Real Decreto de Carlos III, por encima del resto de circunstancias narradas. Más bien, el anhelo principal del escritor paraguayo es, en el marco de este contexto histórico particular, tejer con suma laboriosidad una obra literaria que haga posible espejar la dimensión humana de algunos seres «intrahistóricos» que muy bien pudieran haber formado parte de ese intrincado experimento social, económico, político, y cultural que conformaron la «Reducciones Jesuíticas» en su tiempo y plasmar la cotidianidad diaria de las mismas dentro de un revolucionario sistema que trataba de apuntar hacia un modus vivendi que permitiera la supervivencia de los indios guaraníes lejos de un mundo exterior colmado de plagas, encomenderos, bandeirantes y toda suerte de ambiciones forjadas por una sociedad civil asunceña carente de uniformidad y orden en sus costumbres generales y hábitos individuales.

Donde Ladrón no llega no es una novela histórica, sino una obra «intrahistórica» (en la concepción unamuniana del término) que trasciende la propia historia, muchas veces escrita de una manera deshumanizadora y des- humanizante, impersonal, y global, y trata de acercarse específicamente hacia aquellos seres humanos que volcaron sus vidas en pro del desarrollo de una comunidad floreciente y próspera, en apariencia, no llevada por un plan o designio económico o comercial, sino por la idea teocrática de conformar el Reino de Dios sobre la Tierra ad majorem gloriam dei.

Mi intención en este trabajo es captar y resaltar este sentido intrahistórico endógeno de la novela y ponerlo a la luz de la perspectiva histórica oficial, con vistas a tratar de comprender mejor un sistema de gobierno fascinante que, sin duda alguna, en su momento, captó la atención del mundo entero, y que, para tristeza de algunos, y gozo de otros, derivó en un trágico destino con su prohibición en 1767. Para ello, después de establecer los antecedentes históricos básicos, compararemos en paralelo la historia y la intrahistoria desplegadas a lo largo de la narración.

\section{ANTECEDENTES HISTÓRICOS}

En España, en el siglo XVI, coexistía una fuerte concepción determinista que giraba en torno a la idea de Dios, y al objetivo histórico de llevar su mensaje hacia otros confines del mundo. Esta idea fija condujo a muchos españoles al Nuevo Continente, en un intento de redimir a aquellas criaturas que desconocían el mensaje de Cristo y llevarlos hacia el camino de la salvación eterna. El hombre del siglo XVI, profundamente católico, basaba su vida
Historia e intrahistoria en Donde ladrón no llega de Luis Hernáez

JOSÉ A. ALONSO NAVARRO 


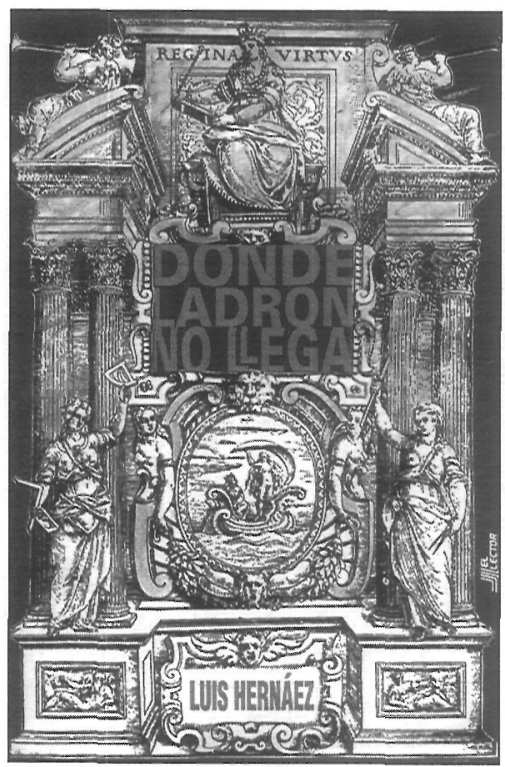

Donde ladrón no llega. Portada. en este ideal histórico que apuntaba hacia el compromiso de apartar al hombre de sus vicios y guiarlo por el buen sendero hacia Dios en una lucha sin treguas y sin concesiones.

La conquista del Paraguay y las tierras rioplatenses vino marcada por esa intencionalidad de conquistar un mundo para Dios. Hubo numerosas decepciones al descubrirse la falsedad de ciertas leyendas surgidas en torno al Paraguay como tierra de oro y plata, no empero, se superaron con facilidad. Los fuertes contrastes climáticos existentes allende los mares tampoco impidieron la ruptura del ideal histórico ni de los perseverantes misioneros ni de los aguerridos exploradores que se adentraron por esas tierras semi-tropicales. La vocación espiritual de los misioneros españoles, según se recoge en algunas crónicas históricas, fue mayor a toda ambición particular o a cualquier otra fatalidad que encontraran tales hombres en términos históricos o territoriales.

Las primeras misiones establecieron inmediatamente un vínculo directo con los indios guaraníes, deseosos de sentir los misterios de la divinidad y de penetrar en su esencia más honda. Este vínculo fue posible, además, gracias a las coincidencias existentes entre ciertos relatos bíblicos dentro del Antiguo Testamento, con algunos mitos guaraníes que versaban sobre la creación del mundo por parte de Avá (Padre-Dios); la creación de la humanidad; y sobre cataclismos ominosos que llevaron a los indios a buscar refugio en otras tierras inhóspitas.

Los religiosos pronto descubrieron el sentir religioso del indio guaraní a través del progresivo y gradual conocimiento de tan rica mitología, con sus arraigadas creencias en la salvación del hombre gracias a un Dios Todopoderoso; su capacidad para discernir entre el bien y el mal; y su fe en la búsqueda de la perfección interna a través del bien absoluto. Los guaranies que encontraron los primeros misioneros hablaban de una entidad espiritual eterna, atemporal, sin fin en su existencia e ilimitada en su poder creador. Como en la religión católica-cristiana, los mitos indígenas citaban a un niño-Dios, y a una Madre sagrada encargada de concebir al ser espiritual de enorme raigambre entre los indios, responsa- ble de crear a la humanidad entera y de encaminarla hacia la redención y hacia su propia inmortalidad.

Este panorama religioso hizo viable, por tanto, el rápido entendimiento entre guaraníes y religiosos. Los religiosos españoles, además, aprovecharon la música y el cántico propios del culto religioso, y la pompa sacra de la liturgia católica para atraer aún más a los guaraníes.

\section{LA HISTORIA}

Las primeras misiones jesuíticas comenzaron a florecer hacia el año 1613, cuando los seguidores de San Ignacio de Loyola, guiados por el Padre General, decidieron crear en el Paraguay una provincia que permitiera la expansión de la fe católica en tierras americanas. La razón de escoger Paraguay para crear un Reino de Dios sobre la Tierra no fue una elección al azar. Los jesuitas sabían muy bien, por otros misioneros, de la avidez de los indios guaraníes por penetrar en una religión que amalgamase esoterismo, espíritu de trascendencia, misterio, y una explicación de ser en este mundo, así como el conocimiento de saber, en términos escatólogicos, el destino del hombre tras su muerte. De este modo, y sabiendo de estos anhelos religiosos, los miembros de la Compañía de Jesús se prepararon para llevar a la zona del Guairá el Evangelio de Cristo.

A diferencia de otros misioneros, los jesuitas trajeron la liberación de los guaraníes; su separación de las ancestrales teogonías que autorizaban la ejecución de sanguinarios sacrificios humanos, e incluso la práctica habitual de la antropofagia entre hombres, niños, y mujeres. En la zona del Guairá, los centros españoles existentes eran la Ciudad Real y la Villa Rica del Espíritu Santo. Éstas fueron fundadas por Ruiz Díaz de Melgarejo en 1556 y 1570 respectivamente. Cerca de ambas ciudades, los primeros jesuitas organizaron sus Reducciones, en las que no pasó mucho tiempo antes de que empezaran a llenarse rápidamente de indios que huían de los peligros de la jungla, y de las encomiendas, donde eran sometidos a un régimen de esclavitud y de abuso terrible.

En la puesta en marcha de la actividad misionera de las reducciones, el énfasis principal, según los estatutos jesuíticos, recaía en Dios, 
como el único Ser Absoluto reconocido en términos de autoridad, y guía principal de todo lo que allí iba a acontecer desde el comienzo de las mismas hasta su finalización, a pesar de todas las controversias que generaron durante su vigencia. Los jesuitas pretendían, dentro de estas reducciones, poner en marcha todo un mecanismo administrativo, social, político, económico, y cultural, pero siempre, pretendidamente, con la mirada encomendada al servicio de Dios. La misión obedecía a designios superiores por encima del plano material. En palabras del historiador Efraím Cardozo (El Paraguay Colonial, 1996) «lo fundamental en el orden misionero era la existencia de ese plan, creación puramente racional, obra de la mente humana, elaborada teniendo a la vista, como finalidad suprema, la salvación del alma humana, la redención del hombre, el triunfo de Dios sobre la tierra».

Con los misioneros jesuíticos y sus reducciones se inició una nueva forma de gobierno; una estructura social asentada en fundamentos teocráticos que habrían de durar más de un siglo y medio. Hasta la expulsión en 1767, sacerdotes jesuitas dirigieron la espiritualidad, formación, conducción, economía, y trabajo de los indios guaraníes con el consentimiento voluntario de éstos. Hasta tal punto la influencia de los jesuitas sobre los guaraníes fue considerable que inclusive los padres recordaban a los esposos guaraníes sus deberes conyugales o maritales a toque de tambor. $\mathrm{La}$ Compañía de Jesús creó un vasto y complejo sistema de vida social que no encajaba con el resto de la comunidad civil laica asuncena. El sistema comunitario generó defensores y detractores, al erigirse como un régimen social contrario al género de vida sustentado por el resto de los paraguayos comunes. Los indios se encontraban conformes con la estructura en que se hallaban, y no suscitaron ninguna rebelión o protesta en contra de esta forma de gobierno. Las leyes por las que se regían los jesuitas eran estrictas, pero justas y organizadas. Desde la mañana hasta la noche la vida del indio estaba rigurosamente guiada por los «país»1.

Cardozo apunta que «nada menos que dos gruesos volúmenes contenían bajo el título de Arapornaguiyeibaba, la detallada prescripción del uso que el guaraní debía hacer de su vida cotidiana. Por la mañana, los guaraníes se dirigían temprano a sus tareas en el campo, que se distribuían en las diversas «chacras» o parcelas de terreno existentes. Las mujeres guaraníes, por el contrario, se quedaban en sus casas a tejer prendas de vestir que posteriormente servían para vestir a los integrantes de la comunidad dentro de la reducción. Cardozo, al igual que Blas Garay (El Comunismo de las Misiones, 1996) hablan de tres categorías de campos: el «tabambae», perteneciente a la comunidad; «el «abambáe», usufructuado por los jefes de familia; y el «tupambae», destinado a sostener los gastos del culto, y el sustento de viudas, huérfanos, inválidos y ancianos. Según Garay, "para que nadie pudiera sustraerse a prestar el contingente de sus fuerzas, los jesuitas buscaron la manera de sacar provecho de los ociosos o de los que mostraban poco apego al trabajo, sometiéndoles a una regimentación particular». A este respecto, una de las extensiones de terreno, el «tupambaé» era el lugar adecuado para quienes rehusaban a trabajar y para los niños pequeños. Si los perezosos insistían en su negativa a trabajar o dejaban de hacerlo, por el bien común, se les imponía un castigo; comúnmente, azotes con un rebenque. Tras ello, según los historiadores, el guaraní debía besar con afecto la mano del "verdugo» (generalmente un padre), quien trataba de hacerle comprender que el castigo impuesto se había ejecutado por el bien de toda la colectividad y por el suyo propio.

Los animales de las reducciones eran de propiedad colectiva, y a su cuidado, se designaba a los guaraníes en diferentes turnos. Muchos indios destacaban por sus habilidades manuales, por lo que los padres jesuitas los adiestraban en el arte de la escultura, cincelado, pulido, pintura, alfarería, mampostería, etc, convirtiéndolos, en general, en auténticos expertos en tallados de madera, pintura de imágenes religiosas, construcciones de viviendas, reparación de templos, etc. En Trinidad, en la actualidad, todavía pueden apreciarse algunas secuelas de lo que fue este fascinante $y$ revolucionario sistema social. Las ruinas se erigen en testimonio viviente de la capacidad organizadora de los jesuitas; de su pericia a la hora de encauzar las habilidades o facultades individuales de cada indio. El anonimato en la
1 «Padres» (religiosos) en guaraní.
Historia e intrahistoria en Donde ladrón no llega de Luis Hernáez

JOSÉ A. ALONSO NAVARRO 


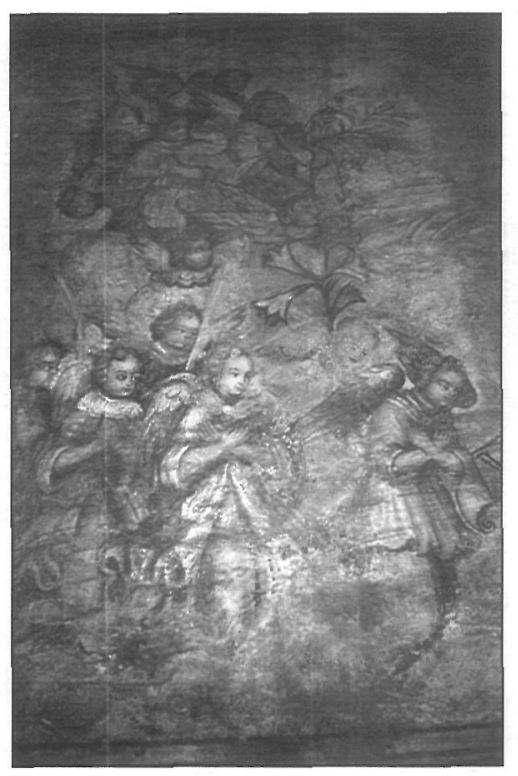

Pintura de Ángeles en Misiones. (Foto: Mar Langa). obra o producto final era una característica de las reducciones, por lo que resulta difícil, hoy en día, atribuir las obras escultóricas o pictóricas existentes a individuos determinados.

En cuanto a la indumentaria, los miembros de la comunidad vestían de igual manera con el objeto de evitar distinciones jerárquicas innecesarias. Solamente en ocasiones solemnes, se permitía el uso de prendas especiales, las cuales, una vez finalizados los eventos sacros, volvían a guardarse en la Casa Parroquial.

Todos los bienes de las reducciones eran compartidos. Cuanto más se producía, más beneficios recibían los miembros de la comunidad. Sin embargo, como están de acuerdo la mayoría de los historiadores paraguayos y noparaguayos, todo este sistema de vida no estaba construido en bases económicas, sino religiosas. El fin último era la protección de las criaturas más desprotegidas y desfavorecidas, en un Reino donde éstas tuvieran acceso a una vida digna y justa; donde sus derechos pudieran ser respetados, y pudieran estar a salvo de rapiñeros, encomenderos y traficantes de esclavos. Efraím Cardozo detalla que «al guaraní nada le faltaba y aunque le era desconocida la institución de la propiedad en el viejo concepto quiritario del derecho romano, era dueño efectivo de la cabaña que habitaba, del pedazo de tierra que cultivaba y del fruto de sus esfuerzos que revertía a sus manos después de satisfechas las necesidades colectivas. Y bajo este sistema, según los jesuitas, los guaraníes eran felices».

La política «comunista» en las reducciones era innegable. Todos trabajaban por el bien común, prescindiéndose de las necesidades individuales y eran miembros de una compleja colmena donde se trabajaba con empeño y sacrificio. Los guaraníes, históricamente, amaban, en verdad, a los jesuitas, o al menos, se sentían cómodos con ellos por haberlos sacado de una forma de vida tribal en la jungla peligrosa y expuesta a innumerables peligros. Este sistema, con sus extraordinarios resultados sociales, culturales y económicos atrajo la atención del mundo entero civilizado en su momento, poniéndose el énfasis principal en este experimento tan prodigioso.
Al comienzo de la fundación de la provincia jesuítica en el Paraguay en 1604, los jesuitas se vieron sometidos a la provincia civil y a sus leyes y normativas. Sin embargo, con el tiempo, este grado de dependencia a la autoridad civil irá desapareciendo progresiva y gradualmente, hasta llegado el momento en que las conexiones o relaciones entre las misiones y la sociedad civil asuncena, con sus correspondientes autoridades, quedarán por completo anuladas. La autoridad del Obispo de Asunción quedará también dejada de lado por parte de los miembros de la Compañía de Jesús. Toda forma de justicia, será, por consiguiente, administrada por ellos mismos con mano firme y sin sometimiento a las leyes españolas ni a los dictámenes legales del gobierno civil de Asunción. El aislamiento de los jesuitas será absoluto.

Los jesuitas vivían cómodamente en sus Reducciones. Nada faltaba, no obstante, se decidió incrementar la producción existente en las misiones para poder sufragar los gastos que las guerras contra la religión católica y contra la propia Compañía de Jesús se estaban produciéndo en la vieja Europa. Para ello idearon un plan: explotar los yerbales del Paraná, cuya explotación estaba en esos momentos a cargo de algunos paraguayos de la zona del Guairá y de Asunción. No les fue difícil a los jesuitas obtener el permiso necesario de las autoridades de Asunción para la explotación de los yerbales (se materializó con la emisión de una Real Cédula con fecha de 1645), argumentando falsamente que los indios se estaban muriendo de hambre debido a las duras condiciones del trabajo y del clima. Lógicamente, esta injerencia de los jesuitas provocó la cólera de los principales explotadores de yerbales de Asunción, que vislumbraban el creciente poder expansivo de los jesuitas por diferentes zonas del Paraguay. Inclusive, los propios miembros de la iglesia ajena a la Compañía de Jesús, se envolvieron de una dialéctica en la que se mostraban contrarios a las acciones de los jesuitas por incrementar sus territorios y propiedades. Entre estos eclesiásticos no jesuitas se encontraban el propio Obispo de Asunción fray Tomás de Torre, dominico, y poco después, fray Bernardino de Cárdenas, franciscano.

En 1649 se produjo el primer intento de expulsión de los jesuitas, mas la supremacía de éstos con sus guaraníes bien pertrechados y 
equipados, hizo imposible que pudiera producirse. Los jesuitas y guaraníes derrotaron y masacraron sin piedad a las tropas asunceñas, mal equipadas y víctimas de una pésima organización. La consecuencia fue el incremento del odio entre ambos mundos. Los asunceños, en general, odiaban a los jesuitas por su progresivo aprovechamiento de extensiones de tierra, prados, bosques y yerbales, y por obstaculizar a los encomenderos para explotar a los indios como antaño. Además, los primeros temían que este poder llegara a acrecentarse tanto que pudiera expandirse incluso por Asunción, lo que significaría la limitación y el enclaustramiento de un gobierno civil. La capital paraguaya en aquella época se regía por la autonomía, independencia, una fuerte libertad, y a veces, por un libertinaje excesivo, lo cual propiciaba constantes cambios de gobernantes y la posibilidad de instituir un gobierno sólido y firme que apuntase al progreso y desarrollo podía amenazar su modus vivendi. A los comuneros asunceños les molestaba, además, el que los jesuitas estuvieran exentos de toda suerte de impuestos, al contrario que el resto de los comerciantes asunceños. Ello supuso que desearan la guerra con los jesuitas. En apoyo a los comuneros, la iglesia, de manera alternativa, se opuso al rápido avance de los jesuitas, puesto que la supuesta creación de un Reino de Dios sobre la Tierra, además de representar para la institución una forma de explotación de los indios, significaba también una manera de recaudar beneficios para la defensa de los intereses particulares de la orden en Europa. En Europa las misiones tenían sus detractores y admiradores. Los defensores de la compañía de Jesús encontraron en las reducciones un modelo social perfecto; sus detractores, una forma de explotación de los indios en beneficio propio y la manera rápida de obtener beneficios y privilegios sin igual que les permitiera mantener su hegemonía en Europa. Entre los admiradores de las jesuitas se encontraban Bufón (Histoire Naturelle, T. VI) y Montesquieu (De l'esprit des lois). Entre los detractores, se encontraban los jansenistas.

En 1759 Portugal comenzó a expulsar a los primeros jesuitas en territorio portugués en nombre de Carvalho. Los franceses siguieron el mismo ejemplo a través del ministro Choiseul. Carlos III al comienzo no tenía una idea muy definida de qué decisión tomar, pero persuadido por el Conde Aranda, conocido vol- teriano y claro enemigo de los jesuitas, el monarca decidió a la firma de la orden de expulsión de los jesuitas el 27 de febrero de 1767.

En la novela de Hernáez se aprecia esta visión de los acontecimientos, y a los asunceños temiendo constantemente esta rápida expansión de los jesuitas.

\section{INT'RAHISTORIA LITERARIA}

Hernáez ubica su historia en las reducciones jesuíticas. De la historia, con el autor, pasamos a la más ferviente intrahistoria, de tal manera que es posible percibir más cerca o más intensamente el ambiente cotidiano de las misiones en el siglo XVIII, poco antes de las expulsión de 1767. El autor se aferra a personajes que convierte en hombres y mujeres de carne y hueso, que muestran de modo gradual sus inquietudes, problemas, anhelos y frustraciones personales. Los propios sacerdotes salen también de los libros de historia y del anonimato para revelar al lector su genuina dimensión y su trascendencia humana, con sus gozos, temores, angustias, y sus más íntimos puntos de vista sobre los acontecimientos históricos venideros. Los personajes hablan por sí mismos, brindando al lector un testimonio «intrahistórico», personal, y directo. Hernáez reúne a una amplia gama: comienza con el indio Bernardino, y a su alrededor se hilvana una historia personal que, progresivamente, se liga con otras sucesivas a las que se conectan otros personajes, con los que Bernardino está, de modo alternativo, irremediablemente unido. Entre tales personajes, se encuentran Salustiana, Feliciano, don Venancio, el negro Jeremías, Sinforiano, Rosa, el Padre Roque, el Alférez González, el Padre Damián, el Padre Jaime, Jacinto, el Padre Forcada, el hermano Juan Bautista, Juan Antonio, el Padre José, Federico, el Padre Sebastián, Ramón, el Padre Ignacio, el hermano Grimau, Gracián, Casiano, Julio, el gobernador Bucarelli, Baltasar...

En Donde Ladrón no llega asistimos a múltiples historias personales que se desarrollan en el aislado ambiente jesuítico. Bernardino se marcha de las Reducciones Jesuíticas, sufriendo un destino determinado por sus padres y llevando consigo el estigma del pecado. Desde niño, había estado viviendo en una sociedad eminentemente paternalista, y ahora, fuera de las reducciones, se encuentra en un
Historia e intrahistoria en Donde ladrón no llega de Luis Hernáez

JOSÉ A. ALONSO NAVARRO 
mundo hostil representado por la sociedad civil asunceña; por los encomenderos, por quienes será apresado; y posteriormente, por aquellos que le forzarán a participar en la expulsión de los jesuitas. Historia e Intrahistoria se amalgamarán en torno a este personaje ficticio, en torno al cual aparecerán otros reales, productos de la historia verídica, como el gobernador Bucarelli o el propio padre Antonio Ruiz de Montoya.

Solo, desamparado, y desprotegido, Bernardino vivirá toda una serie de aventuras que mostrarán la desigualdad entre el modo de vida de los jesuitas e indígenas y los asunceños: aquéllos, trabajadores y perfectamente organizados, y, éstos, con un gobierno civil laico arraigado en Asunción, y apegado a un sistema de vida desorganizado y caracterizado por marcadas diferencias sociales. De vivir protegido y a merced de los jesuitas, el indio Bernardino servirá después en la casa de un potentado español tras su captura por los encomenderos. En su nuevo hogar, llevado por un destino ingrato, trabajará por algún tiempo hasta convertirse en uno de los «soldados» encargado, paradójicamente, de contribuir a la expulsión de los jesuitas de sus territorios. Sin embargo, el destino elegido por él mismo, será otro. Éste, presa de una obsesión traumática, guiará parte de su vida hasta el día de su muerte. «Hijo del pecado», como se le decía en las misiones, tuvo como padres a Jacinto, un hábil y muy apreciado artesano por los jesuitas, y a Rosa, la amante de su padre, ya desposado con otra indígena en las misiones. Bernardino, en cierta manera, pagará el pecado de su padre y debido a la estigmatización que esto supone, contrario a las férreas normas jesuíticas o religiosas, no tendrá más opción que escapar de una atmósfera sofocante. El destino trágico de Bernardino sólo lo conoceremos al final del relato; destino que hará reflexionar al lector sobre la idiosincrasia del indio guaraní «inculturizado», expuesto a una forma de vida radicalmente opuesta, en origen, a la suya.

Bernardino se sentirá avergonzado por haber sido el fruto de una relación condenada por los jesuitas. Su gran enemigo será el Padre Roque, quien, desde el principio del descubrimiento del "pecado", se mostrará intolerante con Jacinto, que estando ya desposado con una mujer, se involucrará en una relación adúltera con otra, rompiendo así una de las normas claramente establecidas en el Araporuaguijeibaba de la Compañía de Jesús. El choque cultural provocado ante esta situación es impactante. Por un lado, nos enfrentaremos a toda una cohorte de cánones eclesiásticos fijados por la iglesia que prohibirán cualquier acto que atente contra la moral y las buenas costumbres, y por otro, la visión libre guaraní que no castiga las relaciones adúlteras y libres. Nos enfrentamos a dos visiones diferentes del mundo; dos formas diferentes de interpretar la vida. El castigo del Padre Roque no se hará esperar y mandará que Rosa, la madre de Bernardino, y amante de su padre Jacinto, sea esculpida en piedra en uno de los altares mayores de la iglesia, en medio de un Purgatorio ígneo y doloroso.

Bernardino, con su mentalidad guaraní, y horrorizado por ello, no podrá soportar la visión de su madre quemada simbólicamente por las llamas del Purgatorio y decidirá, de manera voluntaria, abandonar las misiones. Bernardino se enfrentará ahora con una idea fija: salvar a su madre Rosa del Purgatorio. Y no importa por cuantas adversidades, aventuras, o peripecias haya de atravesar. Esa obsesión estará perenne en su mente hasta verla apartada de la afrenta pública y lejos de un lugar pétreo rebosante de llamas inmisericordes. Su idea será la de regresar lo antes posible a las misiones y poder llevar cabo su plan. De momento, tendrá que adaptarse a las circunstancias impuestas antes del pensado retorno. Su forzado alistamiento a las tropas de los españoles y paraguayos asunceños encargados de hacer cumplir la orden de expulsión decretada por Carlos III en España en 1767, le brindará la posibilidad de acercarse a las misiones sin despertar sospechas. Para ello, antes trabajaba en la hacienda de don Venancio Carrillo y Pedroza, lugareño destacado de Asunción, a quien el gobernador le pidió encarecidamente que le permitiera disponer de algunos de sus trabajadores para contribuir a expulsar a los jesuitas de sus territorios. La idea le disgustó bastante, puesto que la mentalidad de este hacendado estaba más situada en las cuestiones domésticas de su propia estancia, que en asuntos de orden político, sin embargo, temiendo una posible enemistad con el gobernador cedió algunos hombres, entre ellos Bernardino y Casiano. Les acompañaba el hijo de don Venancio, Julio. En añadido, se agregaron el capitán Gracián y el gobernador 
Bucarelli, que iba a llegar desde Buenos Aires con aproximadamente mil quinientos hombres, con destino a Candelaria, capital de las Reducciones.

Hernáez nos muestra en su libro a los jesuitas reducidos en su propia reducción, donde las noticias que llegan no son sino pequeños retazos de información o sucedáneos más apegados a rumores que a hechos reales. Viven en un mundo sin preocupaciones, casi cerca de lo idílico. Sin embargo, algunos como el Padre Roque y Damián, no se sustraen a estos rumores, se preocupan y buscan la razón de su expulsión de los territorios que habitan. Estos dos jesuitas se preguntan qué mal han podido ocasionar en el Paraguay. En Donde Ladrón no llega, están convencidos, por tanto, de los buenos designios que les han llevado a la creación de un lugar donde los indios no están sometidos a ningún régimen o sistema de esclavitud y donde pueden vivir con ellos, voluntariamente, libres de persecuciones y acosos que pongan en peligro su integridad y dignidad como personas o criaturas del Dios.

En la novela, se presenta una visión más anecdótica que histórica de los hechos. Sin embargo, muchos acontecimientos de la historia expuesta no escapan a la visión intrahistórica del relato que llega a combinar personajes reales con personajes ficticios. En Donde Ladrón no llega, los jesuitas están perfectamente convencidos de su buen actuar y proceder. $\mathrm{Da}$ mián dirá: «En las ciudades de Dios se come bien, se construye, se estudia, se trabaja en las artes...el pueblo indio trabaja en las artes, algo que les resulta casi imposible de creer, y que realmente no creen, porque desconfían más bien en alguna engañifa, en algún artificio que manipulamos nosotros interesadamente». Los jesuitas son concientes de la realidad de los acontecimientos futuros y surge entre ellos la duda de oponer resistencia o acatar sumisamente la orden del Rey. La historia expondrá la decisión de los miembros de los jesuitas por abandonar sus territorios pacíficamente y renunciar a cualquier resistencia violenta.

\section{CONCLUSIÓN}

La historia no aclarará lo suficientemente bien los verdaderos motivos de las expulsión de los jesuitas, ni tampoco será la misión intrahistórica de Hernáez exponerla o inducir- nos a favor o en contra de una u otra opinión sobre un hecho sin precedentes que marcó todo un hito dentro del ámbito histórico. Las misiones jesuíticas tuvieron sus detractores y defensores por la trascendencia que este sistema de vida tan bien conformado adquirió, el cual, sin importar las razones que las impulsaron (teocráticas, políticas, económicas, sociales, culturales, religiosas, etc.) no estuvieron exentas ni de errores ni de aciertos, como tampoco dejaron de atraer la mirada del mundo entero.

La historia pondrá de relieve, como también lo hará Hernáez en su libro, que los jesuitas obedecieron con extrema humildad y resignación la cédula real de Carlos III. En el libro de Efraím Cardozo puede leerse: «Yo - dijo el Padre provincial al comisionado de Bucarelli- en nombre mío y de los misioneros mis súbditos, me sujeto absolutamente a ese precepto del Rey y lo acato y pongo sobre mi cabeza». La tristeza de este proceder se refleja con extrema profundidad al final del libro de Hernáez, donde historia e intrahistoria se encuentran y amalgaman, para que sea el lector crítico quien diga la última palabra. Finalmente, el libro de Hernáez no pretende contar detalladamente la historia tal y como ha sido contada con mayor profundidad por diferentes historiadores, con fechas, circunstanciales reales, y nombres de destacados personajes, sino compilar breves historias anecdóticas entretejidas que proyecten la voz y dimensión humana de las mismas. Bernardino, que jamás aparecerá en la historia oficial como un personaje histórico de relevancia, tendrá un papel protagonista en la intrahistoria de Hernáez, desde el comienzo de su aparición en el relato, hasta el final de su trágica muerte, cuando haya culminado felizmente su propósito a costa de su propia vida. Junto a él, otros personajes ficticios y reales, irán deshilvanado sus historias en un Reino de Dios sobre la Tierra forjado eminentemente por la mano del hombre.

\section{BIBLIOGRAFÍA}

Cardozo, Efraím. El Paraguay Colonial. El Lector. Asunción, 1996.

Garay, Blas. El Comunismo de las Misiones. El Lector. Asunción, 1996.

Ruiz de Montoya, A. La Conquista Espiritual del Paraguay. El Lector. Asunción, 1996.
Historia e intrahistoria en Donde Ladrón no llega de Luis Hernáez

JOSÉ A. ALONSO NAVARRO 


\title{
EL ELEMENTO MUSICAL EN LA OBRA DE RENÉE FERRER
}

\author{
MARÍA GABRIELLA DIONISI
}

1

Ferrer R., Las cruces del olvido, Asunción, Intercontinental, 2001, p. 9.

\section{2}

Ibidem, p. 11.
El elemento musical en la obra de Renée Ferrer

MARÍA GABRIELLA DIONISI
Al analizar la obra de Renée Ferrer, que se compone de diecisiete poemarios, dos novelas, cinco colecciones de cuentos, algunas de las cuales para niños, y una pieza teatral, nos damos cuenta de su gran vitalidad creativa, de su capacidad de expresarse utilizando diferentes géneros literarios.

Perteneciente a la llamada generación del $‘ 60$, nuestra autora ha contribuido con su quehacer literario a la renovación de la literatura paraguaya, a través del uso de temáticas y técnicas innovadoras.

La poesía es, sin duda, el campo en el que ha dado pruebas fehacientes de sus capacidades artísticas. En efecto, todo su trabajo poético está impregnado de una gran libertad imaginativa $y$, al mismo tiempo, de un profundo sentido de la palabra concreta en la descripción despiadada de la realidad que la rodea.

Ella misma, en la «Presentación» de su último libro, Las cruces del olvido, evidencia esta actitud al afirmar que «el poeta escribe sobre aquello que sacude hasta la raíz sus fibras más recónditas. El amor, la muerte, el tiempo, la soledad son temas inevitablemente frecuentados, a través de los cuales explora su propia emoción o ingresa al territorio de los grandes interrogantes; sin embargo, no es extraño que trascienda su interioridad para mirar a los otros, asumiendo como propia la desdicha o la dicha de los demás, actuando como caja de resonancia del drama humano, con sus atroces o sublimes consecuencias» ${ }^{1}$.

De hecho, su poética, caracterizada por la musicalidad y la armonía, tiende a la construcción de un cosmos luminoso y obscuro al mismo tiempo, en el que brilla altiva la muer- te. Todos los elementos de la naturaleza, el mar, los árboles, los pájaros, confluyen en una sola voz cuyo timbre refleja la seducción de los sentidos, el abandono total de la mujer, la libertad del erotismo que amplía las vibraciones de su corazón para luchar contra el tiempo que pasa.

De la misma manera, los temas sociales, el conflictivo marco histórico del que forma parte, penetran en este universo buscando en la palabra su posible salvación.

En Desde el Cañadón de la memoria de 1984, dolorosa y vibrante conmemoración de los caídos de la guerra de 1932 y simbólica continuación del poemario Los treinta mil ausentes: elegía a los caídos del Chaco de Josefina Plá, así como en Las cruces del olvido de 2001, escrito «en el nombre del 'marzo paraguayo», Ferrer trata de fijar en la página el dolor colectivo de la ausencia, de levantar su voz contra la ignominia de una guerra fraticida y de la crueldad de todos «los fariseos - banderillas indómitas en el lomo del Mal»².

Además, su compromiso por transformar en pura poesía las emociones, las congojas y los sinsabores personales, a partir del primer poemario, Hay surcos que no se llenan de 1965, ha engendrado una búsqueda continua de nuevas formas estilísticas.

Pasando del verso libre al soneto tradicional, del uso abundante de la metáfora y del símbolo al crudo realismo, Renée Ferrer logra sumergirnos en un universo complejo y multifacético en el que conviven erotismo, sensualidad, relámpagos de felicidad y amarga tristeza, horror por un mundo envilecido por el abuso y la perversión. 
Un universo en el que a veces la palabra se diluye en imágenes livianas, mientras que en otras nos atrae hacia el abismo insondable de un mundo en progresiva decadencia.

Dicha exploración de las nuevas posibilidades que ofrecen los instrumentos estilísticos tradicionales le lleva a experimentar una fusión entre la música y la narración: jugando con las palabras, Ferrer captura los ambientes, las vibraciones de la primera y las incluye en la segunda.

De esta manera nace, en 1987 , el poemario Nocturnos en el que la búsqueda constante de la palabra precisa del verso rítmico, se enriquece de la perfección compositiva e interpretativa del elemento musical concreto.

El libro, compuesto por trece poesías, agrupadas en cuatro trípticos, más una poesía suelta, tiene como temas principales, como se nota leyendo los mismos títulos, el amor, la maternidad, el tiempo, los enigmas de nuestro mundo contemporáneo.

Los argumentos forman parte de la poética ferreriana pero la novedad estriba en el acompañamiento musical que la autora da a los textos, puesto que cada uno de ellos está relacionado con un Nocturno del gran "poeta del piano", Fryderyk Chopin.

En efecto, para cada poesía, como epígrafe, Ferrer indica el número del Nocturno elegido, invitando al lector a recordar la melodía y a seguir el ritmo durante la lectura de los poemas.

En el «Prólogo» al libro, ella misma declara: «mi intención fue escribir poemas cuyos versos se correspondieran con las frases musicales, el ritmo y los silencios de los Nocturnos de Chopin, logrando una unidad total entre el sonido y la palabra, sin que ellos ultrajasen la música, ni la utilizaran como apoyatura». Pero, al darse cuenta de que el intento habría sido no sólo «imposible sino inauténtico», ella opta «por descifrar el eco de su música [...] expresando angustias existenciales mías y una concepción del mundo, de la vida y de la muerte»³.

Pero, ¿por qué elegir a Chopin? Probablemente porque, como ya en 1841 escribió Robert Schumann en uno de sus estudios críticos, así como «egli disse ch'era stato ispirato per le sue ballate da alcune poesie di Mickievicz», al mismo modo "un poeta potrebbe trovare molto facilmente le parole dalla sua musica; essa commuove nel più profondo dell'anima» ${ }^{4}$.

La emoción que emana de su música y que es la transformación pura y perfecta de su mundo interior en un lenguaje musical, atrae a Renée Ferrer, involucrándola y empujándola a la expresión libre de sus más íntimos pensamientos. Así como sucede en los Nocturnos de Chopin, a veces la armonía de sus poemas es intensamente dolorosa, otras nostálgicamente suave. Saltos de fuerza apasionada se alternan a voluptuosos abandonos, a desahogos líricos, a juegos infantiles e imprevisibles, a abruptas imágenes de vidas sin salida:

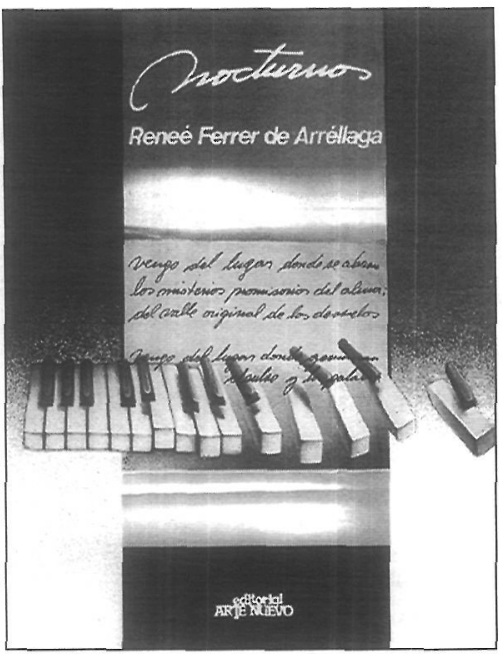

Portada de Nociurnos.

En las islas del tiempo llora el hombre cegado por fogatas innombrables; bajo sus venas palpitantes brota el frío manantial de las congojas. $[\ldots]$

Llegará a la luz, alguna vez,

$\sin$ agobio, sin odio, plenamente? ${ }^{5}$

También la gráfica de los poemas está relacionada con la música. En una reciente entrevista nos explicó la técnica con la que elaboró su trabajo, afirmando que "los versos largos que se caen de los renglones, son como las frases musicales que se van desgranando en los Nocturnos. Busqué palabras con vocales graves para representar los sonidos graves, palabras con vocales suaves para los sonidos agudos y pianísimos. Antes de empezar a escribir los poemas hice gráficas de cada uno de ellos con rayas más gruesas o muy finas para significar los sonidos, espirales para significar los pianísimos, espirales más fuertes o menos pintadas según el sonido de esos pianísimos, y eso fue lo que traté de pasar a las palabras» ${ }^{6}$.

Sólo en la última poesía el ritmo cambia. La necesidad de representar un acontecimiento histórico, como el encuentro-choque entre árabes y españoles, lleva a Ferrer a inspirarse para sus versos en la música de Enrique Granados, el gran compositor español, admirador de Chopin y expresión del espíritu de su propia tierra.
3 Ferrer R., Nocturnos, Asunción, Arte Nuevo, 1987, p. 9.

4 Schumann R., La musica romantica, Torino, Einaudi, 1982, p. 192

5 Ferrer R., «Angustia», en Nocfurnos, cit., pp. 87-89.

6 Entrevista inédita con Renée Ferrer, febrero 2002.
El elemento musical en la obra de Renée Ferrer

MARÍA GABRIELLA DIONISI 


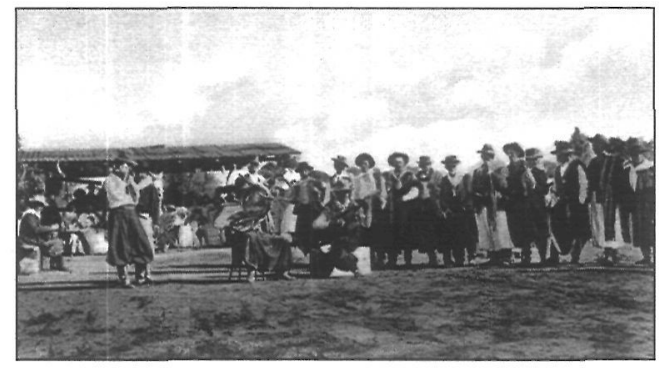

Fiesta de 1910. (Foro: Archivo de Jorge Rubbiani).
En «Quejas o La Maja y el Ruiseñor», cuyo título recupera el de uno de los cuadros de Goyescas de Granados, los versos nacen como homenaje y representación alegórica de la conquista de España por parte de los árabes y de su posterior abandono. Pero, al mismo tiem7 Ferrer R., "Quejas, o la Maja y el Ruiseñor», en Nocturnos, cit., p. 115.

8

Idem.

9

Ferrer R., «Tiempo», en ibídem, p. 71.

10

Ferrer R., Los nudos del silencio, Asunción, Arandurâ, 2000, p. 80.

11

Ibídem, p. 204.

12

Ibidem, p. 152.

13

Ibídem, p. 14.

14

Ibidem, p. 17.
El elemento musical en la obra de Renée Ferrer

MARÍA GABRIELLA DIONISI po, constituyen el canto apasionado y melancólico de «los majos enamorados» del músico español, que en Ferrer se convierte en el recuerdo amargo y triste de su pasado amor.

La doncella (España) a veces evoca imágenes sensuales en el furor de los encuentros, otras su nostalgia rememora la paz conquistada cuando «tu congoja ancestral / se consoló con mis besos» ${ }^{7}$.

En el final, la voz del ruiseñor (el árabe) se diluye en un último susurro, convencido de que

...en ti cantará,

hasta que muera el tiempo,

la diadema de agua

que te ceñí en la frente ${ }^{8}$.

De tal manera, Nocturnos es el libro de la añoranza, del tiempo que huye y cuyo

... paso es un enigma

que perdura y se obstina en cada flor del universo ${ }^{9}$

y es el libro también de la búsqueda de la armonía a través de la musicalidad de la palabra y de las melodías de Chopin.

Por el contrario, la novela Los nudos del silencio, publicada en 1988, es la representación del papel psico-terapéutico, liberatorio de la música y sobre todo de su valor de medio de comunicación entre los seres humanos porque, como afirma una de las protagonistas, «la palabra no es ciertamente el único vehículo del conocimiento» ${ }^{10}$.

En el texto ya no queda rastro de románticas nostalgias ni de cósmicas consideraciones sobre el destino del hombre, sólo encontramos el despiadado autoanálisis de dos mujeres cuya vida se encuentra estrechamente vinculada durante una hora o poco más.
Estamos ante un tiempo cronológico mínimo pero que se dilata al máximo, por ser el tiempo de la memoria que nos revela un pasado próximo y remoto, desalentador y conflictivo.

A través de un monólogo interior alternado, las dos protagonistas, Malena y Mei Li, diferentes «hasta el abismo en circustancias», iguales «hasta el absurdo en la congoja» ${ }^{11}$, animadas por la música de un saxo que «se interna como un dedo agudo en los intersticios recónditos del ser» ${ }^{12}$, tratan de reordenar el desorden de sus vidas, de sacar a la luz un mundo aún no expresado.

Su encuentro es fruto de una casualidad, de un «fatal error» del protagonista masculino, Manuel que, al llegar a París, «la ciudad donde germinan como hongos los placeres» ${ }^{13}$, decide ir con su mujer, Malena, a un espectáculo de streap-tease.

Lo que va a ocurrir en las horas siguientes ya no está bajo su control, como hasta aquel momento siempre había sucedido en su vida de hombre acostumbrado a mandar dentro y fuera de casa. Todo a su alrededor preanuncia un desenlace catastrófico para él, catártico para su mujer, hasta aquel momento víctima silenciosa de una sociedad machista de la que Manuel representa el perfecto prototipo.

La misma ciudad, perdida su imagen tradicional de capital del amor como diversión galante, fascinante juego sentimental compartido, los acoge entre tinieblas. Ellos, «empalidecidos por unos faroles mortecinos ${ }^{14}$, tan en contraste con las luces características de la Ville-Lumière de la Belle Epoque descrita por autores como Alberto Blest Gana o Eugenio Cambaceres, se tumban en una sala envuelta en una «sórdida niebla artificial», donde se está representando un porno-show lesbiano, protagonizado por una bailarina oriental.

Es como entrar en un túnel sin salida, bajar a los infiernos, allá donde las voces se elevan para llorar sus penas, para confesar y expiar sus culpas.

La estructura polifónica de la novela se halla ahora ante su máximo desenlace; cada personaje cuenta su propria historia, hasta escudriñar los más obscuros recovecos de sus ánimas.

Así como ya notó David Foster al reseñar la novela y como nos confirmó la misma autora, destacando su atracción por la precisión matemática de la música de Johann Sebastian 
Bach, Los nudos del silencio se basa sobre la forma musical de la fuga del gran compositor alemán.

En la planificación de la novela, se pueden vislumbrar los elementos peculiares de la $f u$ ga: la contraposición de diferentes voces (soprano, contralto, bajo, a las que a veces se añaden otras más), cada una con su propria individualidad y la presencia de dos momentos fundamentales (la exposición y el episodio) que se alternan continuamente.

De hecho, aquí también nos encontramos con tres voces narrativas (Malena, Manuel, Mei $\mathrm{Li}$ ), a las que se suma un autor omnisciente y el personaje eje de la narración: el saxo. Todos ellos, a niveles y con tonalidades diferentes, expresan el tema principal, la condición de humillación y discriminación de la mujer de cualquier clase social y nacionalidad.

A éste se le añaden episodios diferentes, acontecimientos de sus propias vidas, recuerdos de miserias y de sórdidas claudicaciones que tratan de explicar las razones del profundo malestar que los oprime.

Además, tenemos lo que se define en campo musical el «controsoggetto», que recuerda el tema principal, ya que es su imagen reflejada. En la novela, éste se reconoce en la presencia de otro tema, la denuncia del poder dictadorial del que Manuel es digno representante, al ser «una discreta pieza en el engranaje de un sistema corrupto que nos envilece por mutuo consentimento» 15 .

De tal manera, nos damos cuenta de que esta estructura satisface una necesidad fundamental de Renée Ferrer ya que, como ella nos explicó, «en mi literatura siempre me ha interesado la participación de diferentes voces, ya sea comunicándose entre sí o como vías posibles hacia el conocimiento humano. Yo creo que no existe «una» verdad, así como no existe «una» voz que tenga el privilegio de ser la única e indiscutible. Todas las voces tienen su cosmovisión, su criterio sobre la vida y las cosas, los sentimientos y las actitudes ${ }^{16}$.

Y son éstas las voces que dan vida a la novela. Voces raras ya que no tienen sonido, voces atragantadas, atrapadas por los nudos de un silencio que les convierte a todos «en cómplices ominosos del cualquier acto ${ }^{17}$. Pero, en algunos casos, el silencio puede transformarse en un lenguaje de solidaridad, puesto que, como afirma Delgado Costa, «es precisamente a través de ese silencio solidario que tanto
Malena como Mei Li describen, identifican y logran romper los nudos que las atan» ${ }^{18}$.

Sólo una voz se oye concretamente en la sala, que «flota dentro de una esfera de música» ${ }^{19}$ : es la del saxofón que cuenta y habla sustituyéndose a las palabras mudas de las protagonistas.

Tenemos que partir de la elección de este instrumento musical para comprender el sentido más profundo de la novela, puesto que el saxofón no es un simple elemento estructural, sino que representa, más bien, otro personaje que actúa autónomamente y que, a lo largo de toda la narración, muerde, corta, acuchilla «el aire con su filo sonoro» ${ }^{20}, 1$ lora, se aduerme, calla, gime, porque «el sonido del saxo no es sonido: es carne y es sollozo y es latido» ${ }^{21}$.

Su misma melodía le atribuye este carácter humano ya que «va arrastrando por imprevistos pasajes su alegría de metal, cayendo después en la congoja; tal cual la vida, que salta desde el más absurdo desenfreno al apaciguamiento entregado de la tristeza. Se deja ir de tono en tono, obstinándose en uno, precipitándose en otro, para deslizarse hasta la pausa, perdurando dentro de un laberinto que sólo el bronce de su garganta consiente»22.

Se convierte en elemento simbólico, no tanto por la evidente similitud entre las palabras saxo/sexo o por la posible identificación entre la forma del instrumento y la del falo, sino por su propio carácter musical, por el tipo de ritmo al que está relacionado, por ser el instrumento ideal del jazz.

Si nos referimos a los orígenes de los elementos característicos del jazz, como expresión de un mundo de hombres explotados, humillados, como expresión lírica de la soledad y de la marginación, nos damos cuenta inmediatamente de la directa correspondencia entre esta música y el tema de Los nudos del silencio.

Además, por lo que atañe a su aspecto formal, tenemos una relación estrecha entre este tipo de música y la estructura de la novela. En efecto, el jazz, nacido de la unión de spirituals, gospels, work songs y blues, en su aspecto técnico, se basa en una continua «conversación»
15

Ibidem, p. 37.

16

Entrevista cit.

17

Ferrer R., Los nudos...., p. 103.

18

Delgado Costa J., «Renée Ferrer con ojos humanos, punto. Dejémonos de hacer tantas distinciones», en Ferrer R. Los nudos..., cit., p. 219.

19

Ferrer R. Los nudos..., cit., p. 26.

20

Ibidem, p. 44.

21

Ibidem, p. 170.

22

Ibidem, p. 46.

El elemento musical en la obra de Renée Ferrer

MARÍA GABRIELLA DIONISI 
Peiró J. V., «Erotismo y escritura antiautoritaria en Los nudos del silencio de Renée Ferrer» en Ferrer R., Los nudos..., cit. p. 264.

\section{5}

Cortázar J., Las armas secretas, Madrid, Catedra, 1989, p. 167.

\section{6}

Ferrer R. «La colección de relojes», en La seca y otros cuentos, Asunción, El Lector, 1986, p. 114.

27

Ibidem, p. 125.
El elemento musical en la obra de Renée Ferrer

MARÍA GABRIELLA DIONISI entre los músicos. Ésta se concretiza en una llamada y una respuesta (call and response) entre las voces instrumentales solistas y el grupo orquestral.

De la misma manera, Renée Ferrer presenta este continuo intercambio entre el saxo-solista y los otros personajes. El saxo llama, convoca, ellos responden: «Un arrebato de notas se interna en la carne. Largas, largas notas penetran en la carne. Sinuosas, lentas, se introducen. Retorcidas, demoradas, dolorosas, se quedan en la sangre. Marea que golpea las paredes del alma. Oleaje desplomándose sobre arrecifes negros. El saxo ha dejado de ser un cuerno de bronce con llaves que unos dedos anónimos presionan, para volverse un hechicero de recuerdos y de olvidos superpuestos, que al conjuro de su pulso se descubren ${ }^{23}$.

De esta forma los tres personajes de la novela, al compás del ritmo del saxo, convertido por fin en «un elemento definidor del erotismo distinto, de liberador del autoritarismo y del miedo reprimido» ${ }^{24}$, dejan que sus pensamientos, sus deseos reprimidos, sus esperanzas salgan a la luz, rompiendo el silencio con su nueva voz.

Imposible, a este punto, no pensar en $E l$ perseguidor de Julio Cortázar, que forma parte de la colección Las armas secretas de 1959. Aquí también el papel del saxo es fundamental, al estar inspirado el cuento en la vida del jazzman Charlie Parker. Pero, en este caso, el propósito del autor es más bien metafísico. A pesar de que Johnny, el genial saxofonista drogadicto, cuente con su música «para explorarse, para morder con la realidad que se le escapa todo los días» ${ }^{25}$, él trata sobre todo de encontrar, a través de ella, la manera para superar el tiempo físico, evadirse de él y llegar al absoluto.

El interés de Renée Ferrer por las posibilidades de una estrecha interrelación entre la música y la escritura no se acaba con esta novela, por el contrario se profundiza aún más en la reciente realización de una versión teatral del homónimo cuento, La colección de relojes, incluido en su primera colección La seca y otros cuentos de 1986.

Este último se coloca en el ámbito de una narración en equilibrio entre real e irreal, entre lo cotidiano y lo fantástico gracias a la presencia de un relato concreto (el recuerdo, por parte del protagonista masculino, pragmático y dominante, de su vida conyugal antes del in- ternamiento de su mujer en un hospital neuropsiquiátrico) y de la descripción de los extraños efectos que se producen cada día en la protagonista al dar los relojes las doce del mediodía.

El elemento distintivo del cuento reside en el contraste entre la imagen pública de Isabel, madre y mujer ejemplar, apasionada de literatura, pintura, música y «mente analítica», y la imagen que de ella se desprende al sentarse al piano, cuando se entrega «a la música, a los Nocturnos de Chopin o las dificultosas Fugas de Bach. Perdía entonces el contacto con la realidad, encontrándose de pronto a trasmano del tiempo, dispersa en el espacio, embriagada y plena. En esos momentos Isabel no era ella, sino música fluyendo sobre el frío marfil del teclado ${ }^{26}$.

La escisión femenina entre interioridad y exterioridad impuesta, tan analizada en la literatura feminista, en el cuento se resuelve por parte de la protagonista tan pronto como se pone a tocar el piano, única forma de huida de la pesadilla de una vida de soledad y de represión.

Pero este deseo de fuga de la cotidianidad, se ve progresivamente aplastado por otra forma de opresión, de enclaustramiento, la del tiempo, marcado por los relojes antiguos que llenan su casa y que la alejan cada vez más de cualquier ilusión de cambios en su vida futura.

Al sonido del piano se contrapone ahora el tic-tac de los relojes que se convierten en ojos que la controlan, en dedos que presionan su «garganta cortándole la respiración» ${ }^{27}$.

En la nueva versión teatral de un acto único dividido en doce escenas, Ferrer introduce algunos cambios estructurales que no sólo son el resultado de la necesidad de adaptar el texto a precisas exigencias escénicas, sino que también responden a una renovada voluntad de hacer hincapié mayormente en dos temas sobresalientes para ella: el del tiempo en su sentido metafísico y el de la lucha femenina para su liberación.

A tal fin, añade dos personajes e invierte la perspectiva de análisis: no es el marido el que recuerda, sino Isabel que, gracias a largos monólogos, interrumpidos sólo por breves diálogos con el esposo, la empleada y un desconocido, cuenta sus emociones y otea sus dudas existenciales. Además, se asiste a un aumento del espacio concreto y simbólico asignado a la 
música que no es un escamoteo escénico, sino es, a veces, un elemento de impacto, otras, el eco rezagado de las acciones.

En este caso los cuadros están acompañados por una de las sinfonías 'londinenses' de Joseph Haydn, la número 101, titulada El reloj y compuesta en 1794.

Como en los trabajos anteriores, Renée Ferrer atribuye a la música un papel clave, como elemento técnico que subraya y refuerza la acción, ya que, con gran equilibrio, la autora escoge los pasajes de la obra de Haydn en relación con los estados de ánimo de Isabel.

Las primeras cuatro escenas son introductoras y nos muestran a la protagonista columpiándose entre frívolos pensamientos estéticos y metafísicas consideraciones sobre el tiempo circular y lineal: «¿Por qué será que nos parece que el tiempo vuela si es una rueda que gira sobre sí misma repitiendo un mismo círculo? [...] El tiempo en línea recta $[\ldots]$ me perturba con su prolongación indefinida huyendo como un tren que se detiene sólo para bajar los muertos» ${ }^{28}$.

Acto seguido, Isabel analiza su relación con el marido, un «desconocido crónico, sumido en las exigencias del poder ${ }^{29}$ y describe su soledad y su refugio en la música, «en un presente perpetuo sin mayores inquisiciones ${ }^{30}$. Hasta este momento la única banda sonora es la progresiva intensificación del tic-tac de un reloj.

A partir de la cuarta escena hasta la novena, empezamos a notar la directa relación entre las acciones y la música de Haydn. El Adagio introductor del Primer movimiento, titubeante y melindroso, pero al mismo tiempo rico de fermento e impulso, destaca la condición de espera y de indecisión de la protagonista. La misma alternancia entre la Sinfonía tocada al piano y la del tocadiscos que encontramos hasta la sexta escena, muestra una con- dición poco definida. De hecho sólo en la octava escena se concretiza la prohibición de tocar. A este punto la música, que sigue difundiéndose autónomamente, se convierte en elemento de protesta contra cualquier forma de autoritarismo.

Por eso, en la décima escena, cuando las primeras reacciones físicas y mentales salen a la luz, cuando el falso equilibrio se rompe totalmente y la protagonista toma conciencia de su propia condición, los acordes del Andante del Segundo movimiento se sincronizan totalmente con las transformaciones de Isabel, incitándola a dar rienda libre a sus emociones, a sus deseos hasta el enfrentamiento definitivo con el marido en la undécima escena.

La duodécima escena constituye el triunfo del gran final, en el que confluyen todos los momentos-movimientos. Avanzando del Primer al Segundo, hasta dilatarse en el Cuarto, cuando la orquestra al completo hace retumbar su voz, en un clima de fiesta y de alegría, la música e Isabel alcanzan juntas el momento de la liberación total.

Acompañada por el Cuarto movimiento que crece con más intensidad, ella puede afirmar por fin: «Ni las campanadas ni el tiempo pueden hacerme daño; sólo enseñarme los múltiples rostros que se esconden detrás de una mentira existencial. Ahora yo soy dueña de mi propio destino. Yo decido qué camino tomar. Este estado me ha poblado de luz. Con la luz vendrá la libertad y el valor de asumirla $»^{31}$.

Un lector atento puede encontrar muchos otros temas de debate en los textos que hemos analizado en estas páginas. Nuestra «interpretación musical» pretende ser sólamente una muestra de las infinitas potencialidades de la escritura poética de Renée Ferrer que, durante todos estos años de intenso trabajo, ha cnriquecido las letras de Paraguay.
Ferrer R. La colección de relojes, Asunción, Alta Voz, 2001, pp. 13-14.

29

Ibidem, p. 26

30

Ibidem, p. 27.

31

Ibidem p. 70 
1

CUNNINGHAME GRAHAM, Robert Bontine. Retrato de un ditador; Francisco Solano López (7865-1870). Buenos Aires: Inter-Americana, 1943.

2

PASTORE, Carlos. La lucha por la tierra en el Paraguay. Montevideo: Antequera, 1972, pp. 148-150.
El nacionalismo lopizta paraguayo FRANCISCO F. MONTEOLIVA DORATIOTO

\title{
EL NACIONALISMO LOPIZTA PARAGUAYO
}

\author{
FRANCISCO FERNANDO MONTEOLIVA DORATIOTO
}

El nacionalismo paraguayo, predominante durante el siglo XX, se confunde con la exaltación de la figura de Francisco Solano López. Ese nacionalismo dominó el mundo político y cultural paraguayo, distinguiéndose a menudo por la apología del autoritarismo militarista y estatista y por la xenofobia.

En marzo de 1870, las tropas brasileñas mataron a Solano López en Cerro Corá, lo cual puso fin a la guerra entre la Triple Alianza y el Paraguay (1865-1870). Hasta fines del siglo XIX, no se dudaba en calificar de dictador al que había sostenido una guerra de su país contra vecinos más poderosos. En Retrato de un dictador: Francisco Solano Lópezt, Robert Bontine Cunninghame Graham relata su viaje al Paraguay en 1871 y el odio de los supervivientes hacia López.

Hacia fines del siglo XIX, Paraguay era paupérrimo, falto de autoestima y carente de héroes paradigmáticos. Había triunfado la ideología liberal, cuyos seguidores despreciaban el pasado despótico y a los antiguos gobernantes. En aquel entonces, empezaba a sobresalir una generación de estudiantes universitarios y bachilleres. Era un grupo pequeño y concentrado en Asunción, que anhelaba la construcción de un sociedad mejor, aunque no disponía de un pensamiento capaz de recuperar la autoestima nacional y a la vez encontrar la solución para una realidad miserable. Esos jóvenes buscaban héroes que encarnaran los valores, supuestos o verdaderos, de la nacionalidad paraguaya. La educación liberal no les ofrecía sino la denuncia de los «antihéroes» que gobernaron el país como dictadores hasta 1870 .
Esas circunstancias viabilizaron el nacimiento en el Paraguay del revisionismo histórico de la figura de Solano López, también conocido por lopizmo. Ese movimiento tenía por objeto transformar la imagen de Solano López de dictador responsable por el estallido de una guerra desastrosa para su país en héroe valeroso y patriótico y víctima de la agresión de la Triple Alianza.

Si bien es cierto que el revisionismo histórico lopizta llenó un vacío ideológico en $\mathrm{Pa}$ raguay, otro fue el motivo de su presentación en la sociedad paraguaya. Al llegar a Paraguay a fines de la década de 1850, Elisa Lynch, compañera de Solano López, no tenía recursos. Durante la guerra, ella compró tierras de gran extensión y varios bienes raíces urbanos. Aunque se dio a conocer la versión de compra, la verdad es que el gobierno paraguayo le regaló 33.175 kilómetros cuadrados del territorio que era objeto de litigio con Brasil; 4.375 entre los ríos Bermejo y Pilcomayo, área reconocida como argentina en la posguerra y 135.000 en la región oriental de Paraguay. Además, Lynch compró 29 bienes inmuebles, de los cuales 27 se ubicaban en Asunción ${ }^{2}$. El enriquecimiento inmobiliario de madame Lynch, como la llamaban los paraguayos por aquel entonces, fue posible porque el estado paraguayo era prácticamente un feudo de la familia López.

En diciembre de 1868, Solano López declaró a Elisa Lynch su heredera universal. Al volver a Europa después de la guerra, Lynch quedó en la pobreza tras el despilfarro de la herencia en París, donde pasó a vivir, y en viaje al cercano oriente. Empobrecida, Elisa 
Lynch intentó, en 1885, tomar posesión de las tierras que le habían sido transferidas. Debido a los tratados de límites firmados en la posguerra, las tierras habían sido repartidas entre Paraguay, Argentina y Brasil. En virtud de la dificultad para alcanzar su objetivo, ella transfirió sus supuestos derechos a su hijo mayor, Enrique Venancio Solano López. Sin embargo, tales derechos no han sido reconocidos por las autoridades judiciales de esos países.

La denegación por parte de las autoridades judiciales paraguayas tenía el respaldo legal de tres decretos dictados por el poder ejecutivo entre 1869 y 1870 . Se había declarado a Solano López traidor de la patria y proscrito. Sus bienes y los de sus parientes fueron embargados, incluso los de la «concubina» Elisa Lynch por el origen «bastardo y ilegítimo» (sic). Los bienes del ex dictador fueron transferidos al estado. Las propiedades de Elisa Lynch, anteriores a las «donaciones» o «compras» de la etapa final de la guerra, fueron embargadas. Al aprobar los tres decretos, el poder legislativo paraguayo bloqueó estratagemas jurídicas de las que podrían valerse sus herederos para reclamar esas propiedades.

Enrique Venancio Solano López procuró, entonces, alejar los obstáculos legales para intentar cambiar el fallo de la justicia paraguaya contrario a su pretensión de recibir los bienes de los cuales sus padres se habían adueñado. Ese es el hecho que explica el nacimiento del revisionismo lopizta que vinculó el nacionalismo a Francisco Solano López. Un informe sobre la situación política del Paraguay, elaborado en 1931 por la Legación brasileña en Asunción, saca a la luz el nacimiento del revisionismo lopizta y explica la transformación de Juan Emiliano O’Leary de crítico en panegirista de Solano López. O'Leary fue el intelectual impulsor del nacimiento del revisionismo para «recuperar» la memoria del fallecido dictador, retratándolo como héroe. O'Leary fue tan exitoso en la tarea de reivindicar esa recuperación que le apodaron El Reivindicador.

El informe diplomático brasileño asevera que los herederos de Solano López, interesados en recuperar sus bienes, se pusieron de acuerdo con los paraguayos influyentes con miras a lograr la revocación del decreto de 1869 y recobrar sus derechos civiles. Una vez que se alcanzara tal objetivo y se creara un ambiente político favorable, sería posible contra-

rrestar los obstáculos jurídicos para que los descendientes de Solano López y Elisa Lynch lograran la devolución de las propiedades y bienes que pertenecían a su padres. «El señor O'Leary se puso a defender los intereses lopiztas inconfesables de dinero» $y$ se mantuvo en ello al darse cuenta que podría obtener

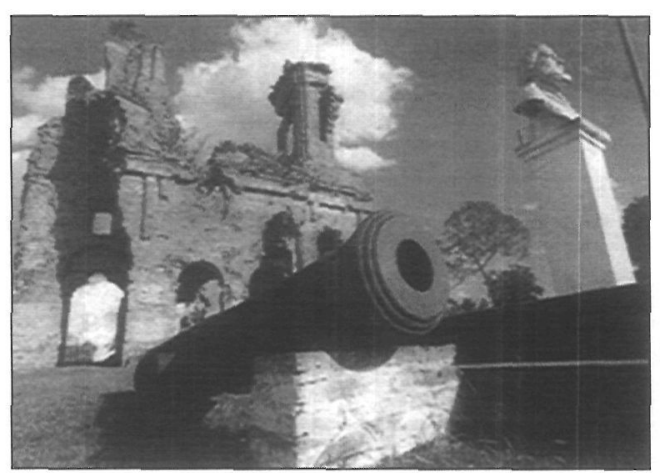

Ruinas de Humaitá (Foto de archivo de Jorge Rubbiani). prestigio y sacar provecho material ${ }^{3}$.

Cecilio Báez, escritor y político liberal paraguayo, sintetizó, en aquel entonces, el carácter del movimiento de recuperación de la imagen de Solano López: «Es simplemente una empresa mercantil, de ganancia, en la que creen los hijos de Linch (sic) que adulan a los poderosos» ${ }^{4}$.

La ideología lopizta no solamente defendió el rol histórico de Francisco Solano López, sino también de los gobernantes autocráticos que le antecedieron: José Gaspar Rodríguez de Francia y Carlos Antonio López. Esa ideología se oponía a los valores defendidos por el partido liberal, el cual se resistía a aceptar los valores tradicionales de la sociedad paraguaya y tenía los ojos puestos en el cosmopolitismo de Buenos Aires. La modernidad de los liberales se oponía al perfil rural del Partido Colorado, cuyo líder principal, el general Benardino Caballero, había peleado en la guerra de 1865-70 como hombre allegado a Solano López. Los colorados se creían nacionalistas y acusaban a los liberales de reflejar valores extranjeros. Para los colorados, los liberales eran «legionarios», es decir, miembros de la Legión Paraguaya, la pequeña fuerza militar de exiliados paraguayos que había peleado al lado de los aliados contra López.

A principios del siglo $\mathrm{XX}$, el ambiente intelectual paraguayo era dominado por un intransigente nacionalismo lopizta que no aceptaba críticas. Ese era el tema de los intelectuales paraguayos de aquella época, de la Generación de 1900, responsables por trabajos históricos que en gran parte idealizaban la sociedad paraguaya de la época autoritaria (18111870). No escribían cuentos ni novelas tampoco. Ignacia, la primera novela paraguaya, fue escrita en 1905 por José Rodríguez Alcalá, un
3

Relafório Polífico sobre o Paraguai (Confidencial), por Arthur dos Guimarães Bastos, $2^{\circ}$ Secretário da Legação em Assunção. Assunção, 5.10.1931. Arquivo Histórico do Ministério das Relações Exteriores do Brasil (Rio de Janeiro), 201-4-6.

4

BÁEZ, Cecilio. «La tirania de Solano López; su aspecto comercial» en JUNTA PATRIÓTICA PARAGUAYA. El mariscal Francisco Solano López. Asunción: Junta Patriótica Paraguaya, 1926, p. 133.

El nacionalismo lopizta paraguayo FRANCISCO F. MONTEOLIVA DORATIOTO 


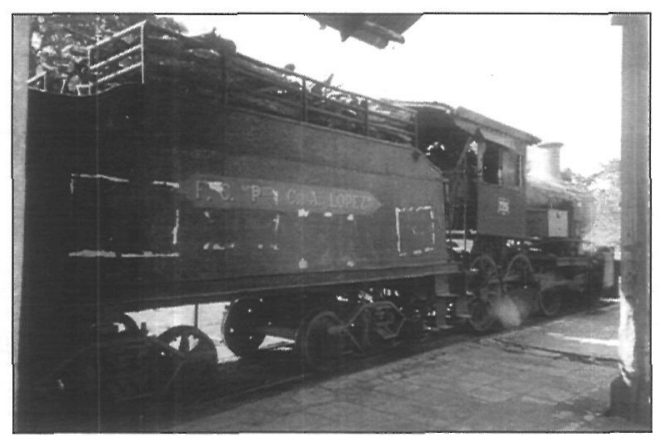

Locomotora. C.A. López. (Foto: Mar Langa). argentino que se había establecido en Asunción. La obra no tuvo acogida entusiasta, puesto que contenía críticas sociales en vez de idealizar la sociedad local. Por el mismo motivo, tampoco hubo buena acogida para la prosa y narración de otro escritor extranjero residente en Asunción: el español Rafael Barret. Los 5 CASTRO, Claude. Historia y Ficción: Caballero de Guido Rodriguez Alcalá. Asunción: Editorial Don Bosco, 1997, pág. 39.

\section{6}

GONZÁLEZ, Natalicio. El Paraguay Eterno. Asunción: Cuadernos Republicanos, 1986, pág. 113.

7

HERKEN KRAUER, Juan Carlos; GIMENEZ DE HERKEN, María Isabel. Gran Bretaña y la guerra de la Triple Alianza. Asunción: Editorial Arte Nuevo, 1982.

trabajos de ambos no glorificaban a Solano López y tampoco a los dos dictadores que lo precedieron.

En las tres primeras décadas del siglo XX, el lopizmo se hizo fuerte y se convirtió en la ideología del Partido Colorado. En 1936, el coronel Rafael Franco ascendió al poder. Tras derrocar al presidente liberal Eusebio Ayala, dictó decreto por el que Solano López se volvió héroe nacional. La predicación de O'Leary se hizo oficial y su nacionalismo dogmático y estatista estaba en armonía con la dictadura de Franco. El culto que se rendía a Solano López mostraba una concepción de estado favorable al régimen de fuerza franquista, puesto que en el culto a Solano López el rol del ejército era trascendental:

no son las instituciones, sino las gestas militares, las que dan cuerpo a la nación. Guiado por un jefe heroico, el ejército encarna naturalmente los intereses del país y es al mismo tiempo el encargado de luchar contra el enemigo «interior» $y$ «exterior» ${ }^{5}$.

Un año antes, en 1935, Natalicio González, escritor y político, había publicado el libro El Paraguay Eterno, en el que se intentaba demostrar que el liberalismo era un pensamiento exótico en el país y que habría una sola «esencia nacional», resultante de la tríada «tierra, raza e historia». Para González, el liberalismo era una doctrina contraria a la naturaleza de la sociedad paraguaya y tenía por objeto arruinar el país. Para salvarse, el Paraguay:

Necesita estrangular el liberalismo sin piedad, con fría decisión. Así tornará a ser la nación grande y fuerte que fundó la civilización en el Río de la Plata. La doctrina liberal es el veneno que emponzoña el alma de la patria ${ }^{6}$.
González fue presidente del Paraguay durante cinco meses, de agosto de 1948 a enero de 1949. Si bien es cierto que su presencia en el poder fue efímera, su influencia sobre el nacionalismo paraguayo fortaleció en el Partido Colorado la ideología favorable al régimen político autoritario y a la intervención del estado en la sociedad. Una ideología que rechazaba las concepciones liberales, políticas y económicas. Alfredo Stroessner, dictador colorado entre 1954 y 1989, heredó esa ideología y la adaptó al contexto internacional y regional de la guerra fría, de combate al comunismo, a fin de fortalecer su propio poder personal.

La mezcla de nacionalismo y lopizmo se hizo ideología omnipresente apoyada por el Estado. A. Stroessner se las daba de continuador de Solano López, pues según Claude Castro «como él, es militar; como él, gobierna de manera autoritaria por el bien de la patria. Todo opositor se considera traidor, 'legionario' a sueldo de potencias extranjeras.»

El nacionalismo lopizta se fue más allá de las fronteras. Atilo Garcia Mellid y José María Rosa, historiadores argentinos que abogaban por el revisionismo histórico de O'Leary, fueron recibidos y condecorados por Stroessner, en 1958. En las décadas de 60 y 70 surgió, en el Río de La Plata, el enfoque «antiimperialista» del nacionalismo lopizta, por el que se atribuyó el origen de la Guerra del Paraguay a la confrontación entre dos estrategias de crecimiento: la paraguaya, sin dependencia de los centros capitalistas; y las de Argentina y Brasil, dependientes del ingreso de los recursos financieros y tecnológicos extranjeros. Esos dos países habrían sido manipulados por los intereses de Gran Bretaña, la mayor potencia capitalista de entonces, con la intención de aniquilar el desarrollo autónomo paraguayo. Esos argumentos no se sostienen históricamente, según lo demuestran, entre otros estudiosos, Herken Krauer y Giménez de Herken, en el libro Gran Bretaña y la Guerra de la Triple Alianza?.

Echar la culpa a Gran Bretaña por la guerra de 1865-1870 dio al conflicto un carácter ideológico y permitió que se retratara a Francisco Solano López como héroe antiimperialista. Ese carácter viabilizó la aceptación del nacionalismo lopizta por parte de la intelectualidad latinoamericana de izquierda. De hecho, en Sudamérica, las décadas del 60 y 70 es- 
tuvieron enmarcadas por gobiernos militares. En la lucha contra el autoritarismo había necesidad de socavar sus bases ideológicas. Por ello, el nacionalismo lopizta antiimperialista fue $\tan$ exitoso entre los intelectuales: por atacar el pensamiento liberal, de conformidad con las acciones de militares golpistas que echaron abajo la democracia y las instituciones so pretexto de defenderlas.

Al fin y al cabo, Bartolomé Mitre, presidente de Argentina, que luchó contra Solano López, fue destacada figura del liberalismo de su país. En Brasil, donde los militares ocuparon el poder entre 1964 y 1985, Caxias e Tamandaré, jefes de las fuerzas brasileñas en la guerra, se hicieron patronos del ejército y de la marina, respectivamente. Además, en las entrelíneas de los trabajos revisionistas de izquierda se puede notar una similitud entre la Cuba socialista, aislada en el continente americano y hostilizada por los Estados Unidos, y el Paraguay de las dictaduras "progresistas» y víctima de Gran Bretaña, la gran potencia de entonces.

El nacionalismo lopizta se impuso en $\mathrm{Pa}$ raguay, aunque los liberales tenían sus propios héroes en la Guerra del Chaco contra Bolivia, la cual tuvo lugar entre 1932 y 1936, bajo la presidencia del liberal Eusebio Ayala. En esa guerra, a diferencia de aquella contra la Triple Alianza, Paraguay no fue derrotado. Además, el conflicto se produjo durante la presidencia de un civil elegido por el pueblo. Sin embargo, a la dictadura de Alfredo Stroessner no le interesaba la apología de héroes civiles y de la eficiencia del Estado liberal; más bien deseaba promover la ideología autoritaria y militarista del nacionalismo lopizta, que se volvió la ideología oficial del Estado stronista.

Respaldado por las instituciones estatales, ese nacionalismo se impuso por la propaganda sistemática, por la persecución al pensamiento crítico en la universidad, por la restricción de la libertad de prensa, y por la inhibición a la investigación histórica con base metodológica científica. A consecuencia de esos actos, hasta los años 80 , la sociedad paraguaya tuvo un conocimiento distorsionado del proceso histórico del país. Había una percepción irreal de sus relaciones internacionales en el pasado así como de su rol en el contexto regional. Se inculcaba la idea de que cabría a caudillos de personalidad fuerte la conducción del Paraguay.
La cohibición a la investigación resultó en el mantenimiento de la ficción histórica nacionalista construida por Juan E. O'Leary y robustecida por la versión del imperialismo inglés. La tan repetida ficción terminó por ganar la apariencia de realidad. Por lo mismo, en 1982 Augusto Roa Bastos escribió que Paraguay, hacia mediados del siglo XIX, había alcanzado «una efectiva independencia y su autonomía económica». Según Roa Bastos, el país fue arrastrado por la Triple Alianza a la guerra tramada y financiada por la «Política de dominación del imperio británico»8.

En 1970, en pleno auge de la dictadura de Stroessner, le tocó a una novela cuestionar el obsesivo nacionalismo paraguayo. En ese año, en el centenario del final de la guerra de la Triple Alianza, el joven escritor Lincoln Silva publicó la novela Rebelión Después, en la que se valía de la ironía hacia el contenido de ese nacionalismo:

Eleuterio, como todos los paraguayos, se sentía mucho más paraguayo que todo el resto. Las causas de su orgullo nativo se remontaban al período guerrero; es decir, a todo el pasado, que no era sino un inmenso campo de batalla racionado por el tiempo. Acá, los únicos que engordan son los cuervos, y como nadie quiere enorgullecerse de ser descendiente de pájaro negro, todo el mundo se vanagloria de sus muertos, que tal vez sean los muertos de uno?

Sin embargo, tres años después, el líder político liberal Domingo Laíno, «un legionario", acudió al nacionalismo lopizta. A lo mejor, lo hizo por provecho político, pero puso de manifiesto cómo la tolerancia hacia el autoritarismo se había pegado a la sociedad paraguaya. En 1973, al pronunciar un discurso en el parlamento paraguayo contra el tratado de Itaipú, firmado entre Brasil y Paraguay, Laíno hizo elogio de José Gaspar Rodríguez de Francia, Carlos Antonio López y Francisco Solano López. En 1989, en el prólogo de la segunda edición de su libro Paraguay: de la independencia a la dependencia (bistoria del saqueo inglés en el Paraguay de la posguerra), Laíno sostuvo que la guerra entre su país y la Triple Alianza fue «imperialista» $\mathrm{y}$ «neocolonial» 10 .
8 Apud. RODRÍGUEZ ALCALÁ, Guido. «Revisionismo histórico y autoritarismo», Múltipla. Brasilia: Faculdades Integradas UPIS, 11 (dez. 2001), p. 80

9

Apud. RODRÍGUEZ-ALCALÁ, Hugo. La incógnita del Paraguay y otros ensayos. Asunción: Arte Nuevo, 1987, p. 68.

10

Guido RODRÍGUEZ ALCALÁ, p. 80 .

LAíNO, Domingo. Paraguay: de la independencia a la dependencia. Asunción: Inter-continental, 1989. $2^{\text {a }} \mathrm{ed}$.
El nacionalismo lopizta paraguayo FRANCISCO F. MONTEOLIVA DORATIOTO 
11

Caballero. Buenos Aires: Editorial Sudamericana, 1987; CabaHero Rey. Asunción: RP Ediciones, 1988; Ideologia autoritaria Asunción: RP Ediciones, 1987 La Segunda República paragua ya (1869-1906). Asunción: ArteNuevo Editores, 1985.

12

Guido RODRÍGUEZ ALCALÁ, "Revisionismo histórico y autoritarismo», p. 83
Hacia fines de los años 80 , cuando se producía el destape en los países vecinos de Paraguay y empezaba el desplome de la estructura todavía represiva de Stroessner, varios intelectuales paraguayos cuestionaron el nacionalismo lopizta. Guido Rodríguez Alcalá lo hizo con ironía en las novelas Caballero y Caballero Rey y en el ensayo Ideología Autoritaria. Ricardo Caballero Aquino en la Segunda República Paraguaya (1869-1906), de 1985, demostró la fragilidad de la historiografía nacionalista ${ }^{11}$. Esos y otros trabajos, que cuestionaban el nacionalismo autoritario, eran parte del proceso de cambios que estaba en marcha en Paraguay y que resultó en el derrocamiento del régimen de Alfredo Stroessner, tras el golpe militar de 1989, conducido por el general Rodríguez.

A partir de entonces, se estableció la democracia, aunque frágil y superficial, representada por la elecciones presidenciales que se celebraron en 1994. Fue como aire puro y nuevo vigor para el Paraguay. Al igual que el sol que entra por las ventanas recién abiertas de una casa que quedó cerrada por años, destruyendo el moho acumulado, el nacionalismo lopizta ha sido corroído en sus bases por la democratización paraguaya. Según Guido Rodríguez Alcalá:
Las cosas han cambiado bastante, porque se concede mayor interés al presente y menor al pasado. Las discusiones 'históricas' (lopizmo versus antilopizmo) van perdiendo interés. La referencia a Francia \& López en los los discursos oficiales ha disminuido ${ }^{12}$.

El aislamiento paraguayo, en sus diferentes dimensiones, llegó a su fin debido a un conjunto de factores: la llegada de la democracia, la facilidad de contacto con el resto del mundo, gracias a las nuevas tecnologías de comunicación y al proceso de integración regional del Mercosur. El aislamiento había sido una protección para el crecimiento del nacionalismo lopizta, el cual reforzó ideológicamente ese aislamiento al darle contenido xenófobo. Hoy, un reto con el que Paraguay debe enfrentarse es el ejercicio de un nacionalismo que sea instrumento, a la vez, de la valoración de su cultura y de la colaboración en la integración internacional. Integrarse sin perder la identidad es un reto considerable, puesto que el ambiente paraguayo en los últimos años, de crisis económica y de tensión política, influye negativamente sobre la autoestima nacional. 
Hugo Duarte (Asunción, 1956) es codirector de la Imprenta-Editorial Arte Nuevo; coautor de la novela a tres manos (Hugo Duarte, Jorge Aymar y Moncho Azuaga) Rasmudel o el relato de tres relatos (1983); autor del ensayo Drogas en Asunción. Más allá del miedo (1989); y coautor, con Enrique Collar, del guión

\title{
LA CONDICIÓN EDITORIAL
}

Miramenometokei (2002), el primer largometraje totalmente paraguayo. Su libro 20 años de poesía está en prensa.

\section{Un acercamiento a las condiciones culturales y editoriales en el Paraguay en los últimos años del stronismo y los primeros de la transición}

\author{
HUGO DUARTE MANZONI
}

Para hablar de la condición editorial del Paraguay en los últimos años de la era del stronismo y los primeros años de la transición hacia la democracia, será necesario evaluar algunas de las características del mercado, y algunos aspectos de su realidad cultural, notablemente diferente del resto de los países hispano hablantes.

Durante más de treinta y cinco años, la dictadura reprimió sistemáticamente toda manifestación que apuntara hacia el estímulo de la consciencia popular, toda búsqueda del desarrollo del pensamiento. Pero habría que analizar si el golpe de febrero de 1989 ofreció alguna opción de cambio para la sociedad paraguaya en lo que se refiere al ámbito cultural.

\section{EDITAR EN UN PAÍS ÁGRAFO}

Hay, evidentemente, un factor de conformación sociológica del país que no ha cambiado ni era esperable que cambiase en el corto tiempo de la transición. Desde el principio, y hasta nuestros días, la historia de nuestro país queda marcada por una característica fundamental: el paraguayo convive con dos lenguas, el guaraní y el castellano. Contra el mito oficial de una nación con dos idiomas, en realidad, sólo un limitado porcentaje de la población es verdaderamente bilingüe.

Aun así, el sector social monolingüe castellano (que no habla en absoluto el guaraní o maneja un limitado número de fórmulas imprescindibles para una comunicación básica con los guaraní hablantes, que son mayoría) se halla fuertemente inmerso en un universo cul- tural cuyo imaginario está constituido por el guaraní.

De una manera u otra, la concepción del mundo del paraguayo pasa por su ascendencia guaraní, totalmente arraigada en la cultura toda: no importa cuán lejos o cuán cerca esté el paraguayo del guaraní, este idioma influye íntimamente en su forma de comunicación, y en su modo de ser y de pensar.

El caso de los que hablan guaraní como idioma materno, y que no consiguen expresarse adecuadamente en otra lengua, se da de manera inversa: éstos tienen que contar también con una fórmula que les permita ser interpretados por los hispano hablantes. Como el sistema educativo se realiza en castellano -ignorando que en el interior del país no es éste el idioma materno - aunque no lleguen a hablar el castellano, acumulan una cantidad mínima de palabras que les sirve para «traducir» lo que el asunceno - el paraguaygua o paraguâtgua, en guaraní - les quiere comunicar.

Una anécdota de Enrique Collar, reconocido pintor egresado de la Escuela Nacional de Bellas Artes de Buenos Aires, sirve para comprender el desfase entre la realidad lingüística y el sistema educativo paraguayo. Me comentaba Collar que al visitar su pueblo (Itaugua Guazú, a unos $35 \mathrm{~km}$ de Asunción, de donde había migrado a Buenos Aires), siempre le llamaba la atención que dos «primitas" mellizas de unos dieciséis años no le dirigieran la palabra. Un día, se le ocurrió preguntarles el motivo, a lo que una de ellas contestó: «ore mboriahu ndo ro ñeei voi la castellano» (en yopará - mezcla de guaraní y castellano-: «nosotros los pobres no habla-
La condición editorial HUGO DUARTE MANZONI 


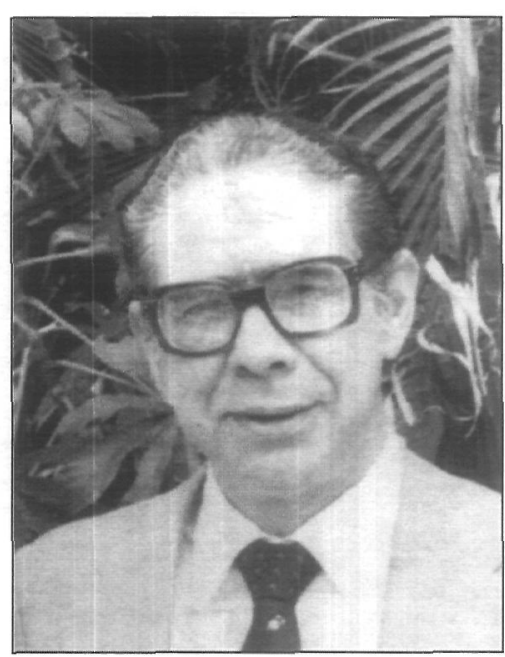

Juan Bautista Rivarola Matto. (Foto: Archivo Jorge Rubbiani). mos castellano»). Sin embargo, las niñas estaban cursando el ciclo básico en castellano, lengua en la que, evidentemente, no podían hablar. Esta situación también nos indica que para el paraguayo, la lengua de los ricos es el castellano.

Además, uno de los problemas fundamentales de nuestra sociedad radica en la incapacidad de la mayoría de sus componentes de hacer confluir la percepción visual (palabra escrita) con la comprensión mental de lo que ésta representa (conceptualización). Si los conceptos en castellano son transmitidos a través de la palabra escrita, en guaraní éstos se trasmiten a través de la imagen, ya que es una lengua oral. Desde luego que hoy ya se le ha adecuado una grafía, pero este hecho no cambia la realidad original: las ideas del guaraní seguirán sin ser escritas, porque los guaraní hablantes no acceden al conocimiento de la grafía a éste asignada.

Como conjunto social, el Paraguay es en realidad una nación ágrafa, una sociedad desvinculada de la palabra escrita. Incluso en el más alto nivel de enseñanza, la Universidad, un buen porcentaje de los egresados se reciben sin haber llegado nunca a leer un libro completo; y sin ser capaces de redactar siquiera una carta personal sin errores mayúsculos.

\section{PROHIBIDO PENSAR}

Y aquí salta a la vista otro detalle: el limitado caudal de vocabulario que maneja el paraguayo medio. En declaraciones de prensa de julio de 2002, el representante de UNICEF en el Paraguay refería que existe alrededor de un $60 \%$ de población analfabeta total o funcional. Esto hace que, en nuestro país, la gente, al no contar con el significado de suficientes palabras, elabore conclusiones propias de lo que está escuchando, por medio de la asociación (asociación que hace a su libre albedrío, de acuerdo a lo que le parece que está leyendo u oyendo). Se puede generalizar este problema, ya que gran parte de la población del Gran Asunción - los suburbios y las pequeñas ciudades aledañas - está habitado por migrantes que vinieron y siguen viniendo del interior del país, así como repatriados de la Argentina, a causa de la siempre acuciante situación económica de ambos países.

Los sucesivos programas educativos, desde la época del dictador (1954) hasta antes del programa actual, se destacaron principalmente por la falta de voluntad política de inducir al alumnado a progresar intelectualmente. Es más: el objetivo primario del gobierno era exactamente lo opuesto a esta necesidad. El estudiante llegaba hasta el tercer grado, o a lo sumo hasta el sexto: en julio de 2002, la ministra de Educación y Cultura, Dra. Blanca Ovelar de Duarte, afirmó que «hasta épocas no tan lejanas» (se refería al stronismo), solamente treinta y cinco de cada mil alumnos acababa el Ciclo Básico (3 ${ }^{\text {er }}$ curso); y que, en la actualidad, ese número había ascendido a setecientos alumnos por cada mil matriculados en el primer grado.

Así, el alumno medio de la época dictatorial podía aprender a sumar, restar, multiplicar... y a leer sólo lo suficiente como para desarrollar un conocimiento relativo del lenguaje, que le permitía, principalmente, recibir los mensajes alienantes de la propaganda stronista. En palabras de Ángel Luis Carmona, docente universitario y reconocido articulista de opinión, «el mayor éxito de Stroessner fue su programa educativo: consiguió analfabetizar perfectamente bien a la mayoría de los paraguayos». Paralelamente, dada la verticalidad del sistema educacional, no se permitía el disenso. En el aula, lo que decía o dictaba el profesor era «Palabra de Dios». Por tanto, se implantaba subterráneamente el mandato «prohibido pensar», lo que necesariamente significaba «prohibido leer», con las lógicas consecuencias para la actividad editorial. Esto puede explicar en parte que una edición promedio en el Paraguay tenga un techo de mil compradores.

Hoy, nuestra realidad sigue siendo la misma: por innumerables razones, parece que el golpe vino a «cambiar una realidad política» para que todo siga igual, al mejor estilo 'gatopardezco».

En cierto grado, es posible que las características anteriormente citadas se hayan repetido en varios de los países de la Hispanoamérica que estaban bajo regímenes autoritarios semejantes al de Paraguay, ya que el apoyo de los Estados Unidos a los gobiernos dictatoriales de aquella época era oficial, y estaba amparado en la lucha contra el Comunismo In- 
ternacional, reflejo de los conflictos nacidos como resultado de la Guerra Fría, en pleno auge durante las tres últimas décadas anteriores al gobierno de Jimmy Carter.

\section{DE DÓNDE VIENEN LAS PALABRAS}

Los canales a través de los cuales se nutría y se nutre el paraguayo son, principalmente, la radio y la televisión - con un gran número de programas «enlatados», traducidos tanto en la Argentina como en Colombia, Venezuela y México y, últimamente, en Miami, lo que nos sugiere que es muy fácil que contengan una serie innumerable de modismos de significados harto diferentes en cada país-. También están los medios de prensa escritos, ya sean éstos los diarios generales de ámbito nacional o la prensa amarilla escrita en "yopará», que circula como supuesto diario informativo. Y, para completar, están las revistas de contenido light que recrean exóticas alternativas de la vida y obra de un prefabricado jet set (protagonizado principalmente por los affaires de modelos, políticos y futbolistas) inventado por los mismos medios. Esta situación no se ha revertido tras el final de la dictadura, sino que, debido a la agudización de los problemas económicos y sociales, y por ende culturales, se ha agravado.

El nivel de estos surtidores de ideas a los que accedía y accede el común de la gente era y lo sigue siendo, tan insuficiente como inapropiado para proporcionarle alguna calidad respetable de información $y$, menos aun, de formación.

Un hecho importante de mencionar concierne a la particular situación de la gran colonia de paraguayos asentada en Buenos Aires, la mayoría auto-exiliados económicos, cuyo volumen se calcula en un millón de almas $(20 \%$ de la población estimada del Paraguay), al que hay que sumar los alrededor de tres millones de descendientes, que tienen nacionalidad argentina. Parte de esta particular masa de migrantes viaja al Paraguay muy seguido, y vuelve llevando nuevos migrantes (para trabajar en la construcción, la zapatería y el empleo doméstico), que luego habrán de continuar la costumbre. Esta formidable masa humana trae consigo los modismos porteños, los restos del lunfardo, así como su particular pronunciación del castellano. Es a través de este movimiento que en el Paraguay se usan palabras como «faso», «birra», «Che loco», y una infinidad de términos más que, como se puede presumir, sólo pueden confundir a cualquier guaraní hablante que haya estudiado castellano en la escuela.

Por otra parte, la globalización trae al paraguayo mundos que para él no existen, pero de los que se le induce a creerse parte. Ello no puede ocurrir, dado que el nuevo conocimiento es nada más que información bien elaborada que solamente da sucesivas pinceladas sobre esas nuevas realidades. Convertir la información en materia prima del conocimiento requiere cierto nivel de capacidad de reelaboración y selección que está fuera de los parámetros de la formación promedio del país; y, por tanto, fuera del alcance de la mayoría de los ciudadanos.

El paraguayo de la época en que la Editorial Arte Nuevo publicaba, leía poco y no siempre alcanzaba a entender con suficiencia lo leído: estos lectores casuales eran los parientes del escritor y un reducido círculo de consumidores culturales. El entorno, así como el sistema educativo, antes que inducir a la lectura, advertía que leer sólo traía complicaciones, que era mejor saber lo justo. Por eso, no llegaba a germinar el interés por la lectura: la idea era que la policía «te miraba mal» si te veía muy letrado; y llevar libros bajo el brazo o tener una biblioteca era semiplena prueba de delito de poder pensar o discernir. Salvo en este último - aunque importante- detalle, las cosas no han cambiado en absoluto. A pesar de que la policía ya no mira los libros con sospecha (sólo con desprecio), si hemos de creer a la Cámara Paraguaya del Libro, el volumen de edición y la venta de libros ha bajado durante la transición. Ser culto ya no es delito, pero sigue disociado del éxito económico, laboral o social, por lo que las nuevas generaciones no consideran la lectura una buena inversión para el futuro: la «aristocracia» local (políticos, empresarios, futbolistas, modelos, etc.) no sólo no es culta, sino que no aspira serlo.

Aunque, lógicamente, existía y existe gente que no se ajusta a lo antes mencionado, esto transmite la idea de que la cultura no resulta imprescindible para lograr el éxito. También cabe afirmar que el libro nunca ha formado parte de «la canasta familiar», por dos razones: por un lado, como ya lo hemos manifestado, «no hacía falta leer»; y por el

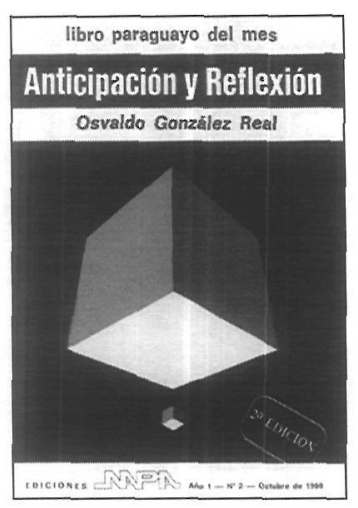

Anticipación y reflexión. Portada.
La condición editorial HUGO DUARTE MANZONI 


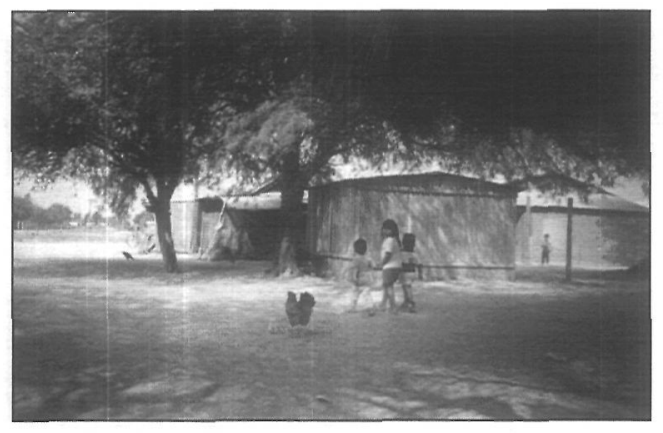

Niños indígenas en un poblado nivaclé. (Foto: Mar Langa). otro, el precio de los libros generalmente es alto, dado que las tiradas, en su mayoría, son de $300,500,750$ ó 1.000 ejemplares.

\section{PUBLICACIONES}

Durante los últimos años del stronismo, se destacó, sin embargo, el auge de las ediciones. Parecía que, a pesar de todo lo dicho, el miedo se iba diluyendo, y estaba de moda el tema cultural. De hecho, otras manifestaciones culturales, como el teatro o las exposiciones de plástica, también tuvieron su «cuarto de hora».

Los géneros preferidos eran los libros de historia, las novelas históricas y la poesía. Con éstos, las Editoras «Napa» $\mathrm{y}$ «El Lector» agotaron obras que, en muchos casos, habían estado guardadas desde hacía años, esperando salir a la luz.

«Napa» fue un efímero pero meritorio esfuerzo de Juan Bautista Rivarola Matto, novelista y periodista que retornó del exilio en los últimos tiempos de la dictadura. Rivarola Matto, siendo hombre de letras, se inició en la tarea editorial - que, de hecho, es una actividad comercial - en el intento de publicar independientemente su propia obra, y de dar salida a una gran cantidad de material que los escritores locales habían ido produciendo, sin tener la posibilidad de darlo a conocer por sus propios medios. Las ediciones de «Napa» incluían una serie de avisos comerciales o institucionales de varios productos y empresas que se avinieron, en aquel tiempo, a compartir la aventura con este reconocido escritor, quien les cobraba un canon como si fuera un aviso de diario. Lógicamente, estos aportes sólo le ayudaban a solventar parte de las publicaciones, quedando él siempre endeudado con las sucesivas imprentas que iba contratando, hasta que, de a poco, iba pagando sus saldos, y recomenzaba con nuevo vigor.

«El libro paraguayo del mes», como rezaba el modesto slogan de este editor, se inició con De cuando Karaí Rey jugó a las escondidas; particularmente interesante por ser una edición bilingüe de la ingeniosa versión de Rivarola Matto de un cuento popular paraguayo. De especial interés entre su producción, por su notable éxito, fueron los tres tomos de las memorias del Coronel Arturo Bray, tituladas Armas y Letras. El Cnel. Bray era un militar de pluma ágil y lengua mordaz en extremo, cuya obra habría sido motivo de cárcel unos años antes, pero la «era Carter» le dio a los paraguayos el placer de poner en duda la historia oficial. Entonces, retratos y anécdotas cáusticas de personalidades intocables habían empezado a salir a luz. Pronto las ediciones de «Napa» dejaron de ser mensuales y, no mucho después, desaparecieron del mercado. La aventura de unos años fue ahogada por la realidad de que no había ni lectores ni compradores suficientes.

Un intento más duradero ha sido el de la editorial «El Lector» que, hasta hoy, continúa en actividad, aunque disminuida y casi limitada a la reedición de obras y autores de interés escolar, integradas en una colección pensada para bibliotecas de colegio. Surgida de una librería que logró un gran crecimiento debido a su estratégica ubicación, y respaldada por un flujo de capital producto de la venta de best sellers internacionales, «El Lector» ha sido la editorial más sistemática del Paraguay, y la que más títulos ha puesto en el mercado. «El Lector» también realizó ediciones locales de la obra de Augusto Roa Bastos.

En cuanto a mi experiencia personal, ésta también fue, en cierto sentido, una aventura. Como hombre de imprenta tenía la ventaja de contar con mi propia impresión, y todo empezó como un intento de ver convertidos en libros algunos textos que me interesaban, además de mis propios títulos. Entonces como ahora, yo no tenía demasiadas expectativas de que la cultura, en el Paraguay, pudiera ser un buen negocio. Sin embargo, creí que podría autosustentarse; y que, a largo plazo, un movimiento editorial iría creando su propio público, cosa que, evidentemente, no ocurrió.

Entre las obras que publicamos, se encontraban el libro de historia Los Británicos en el Paraguay (1984), de Josefina Plá, autora española afincada en el Paraguay, y auténtico referente cultural en este país; la Enciclopedia de Ciencias Naturales y conocimientos paraguayos (1985), del Dr. Carlos Gatti, que llevaba veintinueve años esperando editor, a pesar de recoger lo que el famoso médico aprendió en sus andanzas por el interior del país, de invalorable importancia para el estudio de los conocimientos dejados por los guaraníes en lo 
que se refiere a la botánica, la medicina natural, el idioma, la etnografía, la antropología y otras tantas disciplinas adyacentes. En materia literaria, Arte Nuevo editó, por ejemplo, el que su autor, Augusto Roa Bastos, dice que fue su primer cuento: Lucha hasta el Alba (1979); las novelas La Isla sin Mar (1986), de Juan Bautista Rivarola Matto, y Los Nudos del Silencio (1988), de Renée Ferrer; y el poemario El Gallo de la Alquería (1987), de Óscar Ferreiro, otro de los baluartes de nuestro mundo cultural.

Para entender las dificultades de la labor editorial en Paraguay por aquella época, baste recordar una anécdota: Rubén Bareiro Saguier, profesor en varias universidades de Francia, estaba exiliado en dicho país cuando presentamos en el Teatro San Martín de Buenos Aires, en un encuentro sobre los problemas con los Derechos Humanos en Paraguay y Uruguay, sus relatos de El Séptimo Pétalo del Viento (1984). Como los organismos de represión de Argentina y Paraguay trabajaban juntos, tuvimos que pasar los libros de contrabando.

Arte Nuevo alcanzó a publicar unos cincuenta títulos antes de parar por falta de respuesta, tanto cultural como económica: editar para vender mil ejemplares, en dos o tres años, era una pérdida de tiempo y dinero. En cierta forma, «contra Stroessner», tenía un sentido emprender una aventura editorial, sabiendo de antemano que su futuro económico era más que incierto, dudoso. Editar era, por decirlo así, una determinación política con frecuencia arriesgada. Esa cualidad de formar parte de la «resistencia» se ha perdido en la pseudo-transición, que sigue hasta ahora sin aportar nada significativo ni a nuestra sociedad ni a nuestra cultura.

Asunción, agosto de 2002 


\section{Renée Ferrer}

Poeta, narradora y ensayista paraguaya, nacida en 1944. Doctorada en Historia por la Universidad Nacional de Asunción, Renée Ferrer es una de las escritoras más prolíficas de su generación. De sus obras publicadas, cabe destacar, en poesía: Hay surcos que no se llenan (1965), Voces sin réplica (1967), Desde el cañadón de la memoria (1984), Peregrino de la eternidad (1985), Sobreviviente (1985), Nocturnos (1987), Viaje a destiempo (1989) De lugares, momentos e implicancias varias (1990) y El acantilado y el mar (1992). En el cuento, ha editado La Seca y otros cuentos (1986), Por el ojo de la cerradura (1993) y Desde el encendido corazón del monte (1994), de tema ecológico. También es autora de poemarios y cuentos infantiles. Ha publicado dos novelas: Los nudos del silencio (1988) y Vagos sin tierra (1999). Ha adaptado al teatro los cuentos «La sequía» de Rodrigo Díaz-Pérez, y «Hay que matar un chancho» y «La colección de relojes», de su propia autoría. Como crítica, ha publicado su trabajo Literatura paraguaya: dos vertientes.
La liberación de la mujer a través de la escritura

\title{
LA LIBERACIÓN DE LA MUJER A TRAVÉS DE LA ESCRITURA
}

\author{
RENÉE FERRER
}

Poco se sabe en el exterior de la narrativa paraguaya actual, exceptuando los textos elaborados fuera del país por escritores varones víctimas del exilio, voluntario o forzoso, el cual, si bien les marcó un azaroso destino de desdicha, contribuyó al contacto con los polos de cultura, y al acceso a las editoriales extranjeras que garantizaron la difusión de sus obras. Nadie ignora los nombres y la excelencia de la producción literaria de Augusto Roa Bastos, Gabriel Casaccia, Elvio Romero o Rubén Bareiro Saguier, pero es menos frecuente que se conozcan los de aquellos creadores, sean hombres o mujeres, que escribieron o escriben aislados dentro del territorio nacional.

Este trabajo intenta demostrar, a la luz de la bibliografía actual, la presencia de la mujer en la narrativa paraguaya, y la manera en que la expresión literaria ha servido de factor liberador.

El aislamiento provocado por las lamentables circunstancias políticas, así como las condiciones geográficas de mediterraneidad, nos condenaron al desconocimiento en el exterior de cuanto se escribió dentro de este espacio que se ha dado en llamar el «pozo cultural», al decir del poeta Carlos Villagra Marsal, o una «isla rodeada de tierra», como acertadamente lo definió Augusto Roa Bastos. En estas expresiones, tan drásticas como penetrantes, está definido nuestro destino de nación condenada a una supervivencia solitaria a espaldas del desenvolvimiento cultural del planeta, $y$, en el mejor de los casos, a contracorriente de las «escuelas literarias» o técnicas narrativas en uso, hecho que conllevó durante mucho tiempo la marca nefasta de la desactualización.
Agudiza esta marginalidad de la prosa de ficción, el peculiar interés de nuestros intelectuales de comienzos de siglo por la reelaboración histórica y la defensa de nuestros derechos sobre la región occidental, tema obligado en el momento de los conflictos territoriales que desembocaron en la Guerra del Chaco.

No obstante las condiciones adversas, la narrativa paraguaya se abrió paso por ese arduo sendero del aislamiento, y son las mujeres con vocación literaria quienes están proponiendo un nuevo ángulo de mira en los últimos años. Las primeras manifestaciones narrativas de acento femenino se centran en los temas costumbristas siguiendo las pautas del relato. En esa línea se encuentran las obras de la neo-romántica Teresa Lamas Caríssimo (1897-1975), quien publica en 1921 Tradiciones del hogar, a la cual le sigue una segunda serie en 1928, más tarde Huerta de odios (1944) y La casa y la sombra (1955), siempre dentro del corte tradicional de la época. Tenemos que esperar la aparición de otra neorromántica, Concepción Leyes de Chaves (1889-1985), quien publica en 1941 su novela Tava-i, tributaria a la vertiente del folklore, para encontrar el punto de partida de la novelística femenina del siglo XX en el Paraguay. Esta autora, que se mantuvo dentro de la línea habitual del costumbrismo y las leyendas en sus libro Río Lunado, mitos y costumbres del $\mathrm{Pa}$ raguay (Bs.As. 1951), se adentra en la novelística siguiendo al inicio la corriente temática y estética del momento, para abordar posteriormente el tema histórico con una biografía novelada Madama Linch (1957). La historia ha 
sido en el Paraguay una cantera de mayúscula frecuentación, a la cual las mujeres no se mostraron indiferentes.

Debemos aguardar a la década de los años sesenta para que la polifacética Josefina Plá (1902-1999), nacida en Islas Canarias, conocida ya como poetisa y ceramista, haga su aparición como narradora con la selección de cuentos La mano en la tierra (1963), inaugurando una óptica cuestionadora, que se adscribe a un realismo crítico, totalmente diferente al costumbrismo en boga. Dos décadas después, el movimiento editorial de los años 80 , aparecido como una suerte de resistencia a la dictadura, y a pesar de ella, rectifica el largo silencio que pesa sobre las obras de ficción de Josefina, dando a conocer El espejo y el canasto (1981), La pierna de Severina (1983) y La muralla robada (1989), colecciones de cuentos que incluyen textos muy anteriores a la fecha de su publicación, donde se encuentra una aguda crítica social. Josefina Plá escribió además, en colaboración con Ángel Pérez Pardella, la novela Alguien muere en San Onofre de Guarumí (1984) plasmando la realidad urbana y rural de su país adoptivo, así como obras de teatro, ensayos, crítica literaria y cuentos infantiles, tal como lo hicieron $\mathrm{Ma}$ ría Luisa Artecona de Thompson (1923), Nidia Sanabria de Romero (1928), Teresita Torcida y otras, pioneras de la literatura infantil en el Paraguay.

Por la misma época se da a conocer Ana Iris Chaves de Ferreiro con la novela Crónica de una familia (1966), donde reconstruye la vida de un grupo familiar a lo largo de varias generaciones, siguiendo el patrón de las sagas europeas. A esta obra le sigue Andresa Escobar (1975) y varias colecciones de cuentos, tales como Fábulas modernas (1983), Retrato de nuestro amor (1984) y Crisantemos color naranja (1989), donde despliega cierto tremendismo e introduce a la mujer como personaje crítico e irónico frente al sexo opuesto y a la sociedad que la sojuzga.

La conocida poetisa Ester de Izaguirre (1924), residente en la Argentina, se revela, en 1973, como una narradora de extraordinaria economía verbal, poderosa fuerza expresiva y un manejo excelente del desenlace imprevisto, con el libro de cuentos Yo soy el tiempo, (Buenos Aires, 1973), publicado en Buenos Aires. A esta serie le sigue Último domicilio conocido (1990), obra que viene a engrosar el boom

de la literatura femenina en el Paraguay, del cual hablaremos posteriormente. Existe en la palabra de Ester de Izaguirre un temblor sugerente y una hondura pocas veces alcanzada con trazos tan escuetos, pero sobre todo se percibe en ella esa certera penetración sobre la situación de la mujer.

No obstante las muestras de estas escritoras al inicio de la segunda mitad del siglo XX, la narrativa de cuño femenino se desarrolla con mayor vigor a partir de 1980, cuando empieza a advertirse una toma de conciencia de género como rasgo liberador, además de una mayor pluralidad temática, así como notables variacio-

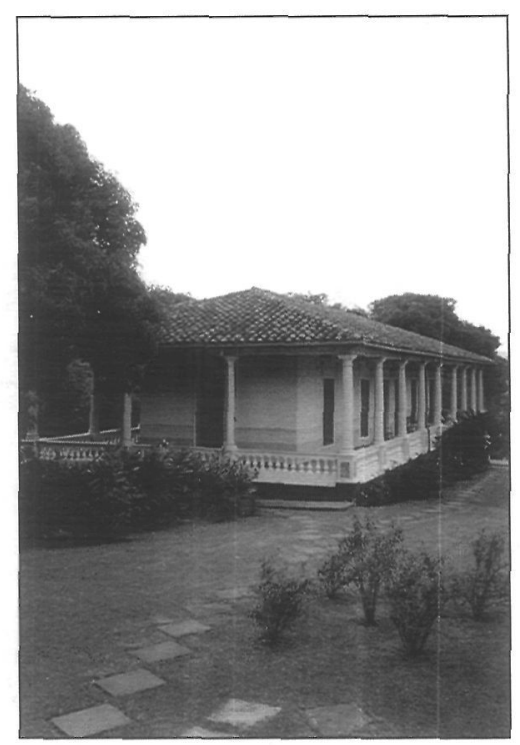

Casa colonial, Areguá. (Foto: Mar Langa). nes estilísticas.

Si las narradoras de principios de siglo se limitaron a escribir dentro de un esquema tradicional, sin apartarse por lo general del costumbrismo o del realismo de la vida rural o urbana; si la escritura de las que les sucedieron constituyó una tímida denuncia de esa sociedad patriarcal y castradora a la cual la mujer se vio sometida desde tiempo inmemorial, es en los últimos veinte años donde podemos encontrar la expresión liberadora de la mujer, dispuesta a contarse a sí misma desde una óptica netamente femenina, ignorando los esquemas que la educación tradicional y el imperio del hombre le han impuesto. Varias son las vías utilizadas por la mujer escritora para conseguir esa liberación a través de la escritura. Las mismas van desde la introspección con el concomitante enfrentamiento consigo misma, hasta el planteamiento de la infidelidad como un derecho a la felicidad; desde el lesbianismo como respuesta psicológica a la explotación sexual masculina a la alienación, la autoeliminación, el crimen o la locura, sin que falten los casos de un franco erotismo o de una rebelión abierta y sin rodeos.

En la década de los ochenta la narrativa paraguaya escrita dentro del país experimenta, en general, una eclosión inusitada. Por un lado autores nuevos o postergados por las dificultades editoriales publican sus obras, amparados en el empuje que la Editorial NAPA dio a los escritores nacionales, por otro la aparición de voces femeninas se manifiesta con gran fuerza y continuidad. Es desde esta década en adelante que se empieza a notar esa

La liberación de la mujer a través de la escritura RENÉE FERRER 


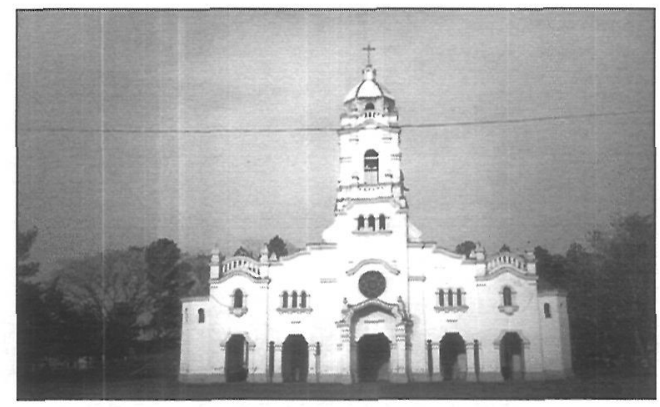

Iglesia. (Foto: Mar Langa). determinación de la mujer en revelarse, y a su vez rebelarse, a través de su propio discurso, sin olvidar que ya anteriormente algunos textos de Josefina Plá pueden considerarse paradigmáticos de esta actitud de reivindicación de la mujer por medio de la palabra escrita.

La primera en abrir el fuego, dentro de lo que podría llamarse «el boom» de la narrativa escrita por la mujer en el Paraguay, es Neida de Mendonça (1933), con Golpe de luz (1983), novela de introspección femenina en busca de la auténtica libertad. El viaje hacia el fondo de sí misma y el descubrimiento de la propia interioridad constituyen el argumento de esta novela perteneciente al género confesional, la cual significó en el momento de su publicación un desafío a la sociedad y una prueba de coraje de la autora frente al espíritu estrecho de la época. Estructurada sobre una base autobiográfi$\mathrm{ca}$, entra sin embargo en el terreno de la ficción mediante el delineamiento de un personaje femenino que después de un intento de suicidio, a través de las sesiones con el psicoanalista, va descubriendo su identidad y conquistando el derecho a ser tal cual es, sin sometimientos ni censuras.

Neida publica posteriormente tres colecciones de cuentos Hacia el confín (1986), De polvo y de viento (1988) y Ora pro nobis (1993), donde con lenguaje poético y sugerente, manifiesta su constante preocupación por la situación de la mujer y la búsqueda de una liberación que la redima de su situación de dependencia física y moral. La rebeldía manifiesta por la autora de Golpe de Luz llega a su máxima expresión en el cuento, escrito en forma epistolar, «Que la muerte nos separe» (De polvo y de viento), donde la protagonista defiende su libertad después de la muerte, ya que no pudo ejercerla en la vida.

Raquel Saguier (1940) se abrió camino en la literatura paraguaya con la publicación de La niña que perdí en el circo (1987), una deliciosa novela de iniciación, donde la autora recobra de la mano de la poesía el perdido territorio de la infancia. Si en La niña que perdi en el circo se vislumbra ya una cierta denuncia a la situación opresiva a la cual se ajusta la vida de una mujer burguesa en una sociedad dominada por el ethos masculino, es en La vera historia de Purificación (1989) y en su siguiente novela Esta zanja está ocupada (1994), donde Raquel Saguier se pronuncia abiertamente contra la desigualdad de los patrones de conducta del hombre y de la mujer. La novela $L a$ posta del placer (1999) completa la obra de esta excelente novelista de prosa lujosa y acabado manejo de la ironía, donde se exterioriza con mayor fuerza la liberación de la doble moral de sociedades tradicionales como la nuestra. El peso resultante de la incomunicación, la soledad y el absurdo son otros elementos que juegan en la trama, donde el protagonista es un prisionero de sí mismo. Nada mejor para dar testimonio de la acción liberadora de la palabra que citar la obra de Raquel Saguier, quien nos describe en La vera historia de Purificación «el duro oficio de ser mujer en una sociedad patriarcal, inficionada de hipocresía y autoritarismos».

Así como las protagonistas de otras autoras se escapan de la opresión por medio de la alienación o la muerte, Saguier opta por la infidelidad de la protagonista como manifestación de rebeldía. En La vera historia de Purificación una mujer madura y ejemplar se rebela contra una vida de renunciamientos y abnegación, manteniendo una relación clandestina que es juzgada por un tribunal imaginario. La voz de la sociedad se deja escuchar con un rigor implacable, dando testimonio de la censura que coarta la vida de la mujer.

La literatura de voz femenina tiene desde los inicios de la década de los ochenta ese tinte de rebelión y cuestionamiento que la convierten en una denuncia social a través de la estética, de la cual Saguier hace gala en su tercera novela Esta zanja está ocupada (1994), donde pormenoriza con agudeza y sentido del humor la corrupción imperante en el país, siguiendo una trama de corte policial sazonada por el indispensable ingrediente de suspenso. «La rebeldía de Raquel Saguier se ajusta a un tono más social que el de sus anteriores obras y se enfrenta directamente con la mentalidad de la sociedad paraguaya dominada por los hombres», nos dice José Vicente Peiró en relación con esta obra. Asimismo se encuentra en Raquel Saguier la utilización de la ironía como arma eficaz de «combatir un mundo desigualitario en hombres y mujeres», lo cual confiere a la obra una incisiva penetración psi-
La liberación de la mujer RENÉE FERRER 
cológica y propone una manera de defenderse del dominio masculino.

Sara Karlik (1935) es otra narradora y dramaturga, residente en Chile, que cultiva la ficción breve y la novela con especial cuidado y abundante producción. Se da a conocer con la colección de cuentos La oscuridad de afuera (Santiago, 1987), afianzando su entrada en la narrativa con títulos tales como Entre ánimas y sueños (1987), Demasiada historia (1988), Efectos especiales (1989), Preludio con fuga (1992) y Presentes anteriores (1996). Tiene publicada la obra teatral No bay refugio para todos, y varias novelas inéditas, tales como Los fantasmas no son como antes; Juicio de la memoria, La mesa larga (1994) y El lado absurdo de la razón. Por la manera de expresar la realidad interna de sus personajes pertenece a una corriente psicologista, ingresando «en la nueva narrativa del subconciente por caminos sesgados pero precisos», con una prosa donde se observa «la continua irrupción de la función poética en el discurso-obsesión narrativo». La múltiple bibliografía de Karlik se vio enriquecida con su última novela Nocturno para errantes eternos (1999), donde retorna al mundo de su infancia, relatando las peripecias del grupo de inmigrantes judíos establecidos en el Paraguay en las primeras décadas de este siglo.

Por la misma fecha de aparición de La niña que perdí en el circo, de Raquel Saguier, Lucy Mendonça de Spinzi (1932) publica Tierra mansa y otros cuentos (1987). Ceramista, periodista, autora teatral y narradora de gran fuerza expresiva, Lucy Mendonça utiliza con suma habilidad el castellano paraguayo en el coloquio, impregnando a su obra de una vigorosa autenticidad. Con tanta versatilidad como acierto, transita los ambientes populares, sórdidos o de refinado intelectualismo, con una sagacidad cargada de ironía, no excenta de un sarcasmo implacable. Luego de un largo silencio Lucy Mendonça de Spinci, utilizando su nombre de soltera, nos vuelve a enfrentar con las circunstancias más crudas de nuestra ambiente en su último libro Cuentos que no se cuentan (1998), donde intercala relatos breves con meditaciones que denuncian las lacras de la realidad nacional.

Cuando un escritor o escritora emprende la tarea de difundir la literatura de su país en el exterior, con el convencimiento de que esa actitud sirve para romper las barreras del enclaustramiento, se enfrenta con respecto a su propia obra a dos criterios contrapuestos: la inclusión dentro del panorama expuesto o la automarginación. Atendiendo al análisis que vengo haciendo de la escritura como agente de la liberación femenina en la narrativa paraguaya, donde cada autora presenta una arista diferente, opté por el primero.

Renée Ferrer (1944) irrumpe en la narrativa en los años ochenta. Atendiendo a la necesidad de denunciar la realidad por un medio más directo que la poesía, publica La seca y otros cuentos (1986), al cual le sigue La mariposa azul y otros cuentos (1987), dirigido al público infantil, y posteriormente Por el ojo de la cerradura (1993), una serie de cuentos donde se intenta desvelar esa otra realidad que está más allá de la apariencia y sólo puede verse «por el ojo de la cerradura». Convocada por una ONG dedicada a la defensa del medio ambiente, aborda el tema ecológico en el libro Desde el encendido corazón del monte (1994). Su obra novelística se inicia con Los nudos del silencio (1988), donde asume la defensa de la vocación de la mujer y la denuncia del sometimiento al sistema patriarcal en una sociedad autoritaria denigrada por la dictadura de Alfredo Stroessner. Su segunda novela Vagos sin tierra (1998), ubicada en la zona norte del Paraguay del siglo XVIII, narra las desventuras de los campesinos que van a la frontera atraídos por la promesa de los repartimientos de tierra.

Los mecanismos de liberación de la mujer van desde la locura, en La colección de relojes, a la alienación voluntaria en El ovillo, hasta el lesbianismo pasivo asumido por $\mathrm{Mei} \mathrm{Li}$ en Los nudos del silencio. Si Malena, la protagonista burguesa, que renunció a su carrera de pianista por el casamiento, se subleva y toma conciencia de su sumisión al varón frente al streep-teese de Mei-Li, ésta opta por refugiarse en una relación lesbiana como respuesta a la abusiva conducta masculina.

Las voces aparecidas en la narrativa paraguaya en la década de los noventa son en su mayoría femeninas, y el género más frecuentado el cuento breve. Milia Gayoso (1962), de prosa escueta y efectiva, inicia su producción con Ronda en las olas (1990), al cual le siguen
La liberación de la mujer

a través de la escritura

RENÉE FERRER 
Un sueño en la ventana (1991) y El peldaño gris (1994), sustentados en la observación de la vida ciudadana, con sus ribetes de desamparo que se encuentra en las urbes. Por su parte Chiquita Barreto Burgos (1947), por medio de un discurso crítico y directo, suma a la bibliografía nacional dos colecciones de cuentos, donde campea el humor y la denuncia. Con pena y sin gloria (1990) y Con el alma en la piel (1994), de hondo contenido erótico, son algunos títulos de esta autora. Hay que destacar que en una sociedad convencional donde la liberación femenina cuenta con un escenario reducido, la escritura de Barreto Burgos constituye un desafío que afianza la postura de la mujer frente a unos patrones de conducta arcaicos, insuficientes para sojuzgarla. Varias son las escritoras y poetas que ejercen el derecho a la réplica y a la libertad a través del discurso poético o narrativo, pero Chiquita Barreto es la primera que articula una serie de cuentos sobre el eje del erotismo.

Predomina en la narrativa actual paraguaya la ficción breve. En 1992 tres integrantes del Taller Cuento Breve, dirigido por Hugo Rodríguez Alcalá, se dan a conocer. La primera es Luisa Moreno (1949), con Ecos de monte y arena (1992), quien utiliza un discurso impregnado de ternura y precisión semántica para abordar temas ecológicos, denunciando el peligro de la destrucción de la naturaleza y el reino animal. A este primer libro le sigue El último pasajero y otros cuentos (1997), donde la autora hace gala de un estilo preciso y de buena penetración psicológica, mezclando muchas veces los planos de la realidad y la fantasía para llegar a la denuncia o al misterio, que queda flotando en el entorno al lector.

Maybell Lebrón (1923) se da a conocer al poco tiempo con Memoria sin tiempo (1992), donde por medio de una prosa prístina, y muchas veces poética, encuentra el tono dentro de la diversidad temática. En Maybell Lebrón se conjugan la denuncia política como en su cuento «Orden Superior» o la afirmación de la libertad de la mujer, que incluso llega al crimen como afirmación de su libre albedrío.

Completa la tríada de ese año Dirma Pardo Carugati (1934), cuyo estilo preciso, de una marcada impasibilidad, potencializa el dramatismo de sus invenciones, reunidas en su libro de cuentos La víspera y el día (1992).
En 1999, con la publicación de Cuentos de tierra caliente, Dirma Pardo Carugati da nuevamente muestras de su habilidad narrativa, utilizando certeramente el recurso del final inesperado. En Dirma Pardo encontramos un planteamiento diferente con respecto a la liberación a través del discurso. Si Neida de Mendoça propone el suicidio del personaje femenino como un escape a la desesperación, Dirma lo encara como venganza en su cuento titulado precisamente «Venganza», publicado en la revista Manzanas al Olmo.

La producción narrativa de la mujer sigue siendo en el presente un fenómeno ascendente. Desde los textos centrados en la vida cotidiana hasta la fabulación fantástico-metafísica, la mujer sigue su derrotero de contar no solamente su mundo personal y sino también «el mundo» tal cual lo ve desde su óptica femenina y muchas veces feminista.

Yula Riquelme de Molinas (1941-2002) da a conocer la novela Puerta (1994), saliéndose de los cánones habituales de la narrativa femenina para rozar la literatura fantástica, subgénero casi inexplorado dentro de la literatura paraguaya. A esta novela se suma Los gorriones de la siesta (1996), donde mediante una fluida relación de los hechos mantiene interesado al lector, creando una buena dosis de suspenso. Posteriormente publicó De barro somos (1998).

Si en otras narradoras observamos que el proceso de liberación del personaje femenino pasa por la locura, la infidelidad, el lesbianismo e incluso el asesinato, en Los gorriones de la siesta nos encontramos con un personaje delicioso, desprejuiciado y generoso, que ejerce la libertad sexual desde la adolescencia, y lo hace con la alegría de saberse su única dueña, sin dejarse vencer por el peso de los complejos de culpa, tan habituales en los personajes femeninos de la narrativa paraguaya escrita por mujeres. El planteamiento de Yula Riquelme se basa en la resistencia a obedecer y la capacidad de tomar las propias decisiones. La novelística no agota la capacidad narrativa de Yula Riquelme, quien escribe además ficciones breves, como lo atestigua el volumen Bazar de cuentos (1995).

Cierra las publicaciones de 1994 el libro de cuentos El Viaje de Delfina Acosta, quien con una agudeza impregnada de ironía transita el paisaje interior de sus personajes, desenmascarando sus sentimientos y los móviles escon- 
didos de la conducta humana. En su cuento «La tía», Delfina manifiesta claramente el papel de sometimiento de la mujer, pero esta vez la conducta servil se adecua a los deseos despóticos de una tía que se opone sistemáticamente a todos los emprendimientos de la sobrina, incluso el de contraer matrimonio. Delfina resuelve finalmente la situación dictatorial con la huida de la protagonista a la rama de un árbol.

$\mathrm{Al}$ año siguiente se suman a este grupo de narradoras de indiscutible valor Susana Riquelme de Bisso con sus cuentos Entre la cumbre y el abismo (1995) y Nila López (1954), quien en su libro Señales (Una intrabistoria) (1995) navega entre la crítica social, el ensayo y el relato certero, y en Madre, bija y espiritu santo (1998) reúne una serie de textos que sin tomar la forma del poema están impregnados de poesía.

En «Despedida al miedo», Nila López nos presenta como solución al problema de la condición de la mujer oprimida por el miedo a ser juzgada y por los complejos de culpa que la sociedad le hace sentir, su propia batalla contra el miedo, de la cual sale finalmente victoriosa. Por su parte, Susy Riquelme de Bisso denuncia la presión social como cerrojo deformante de la conducta de la mujer en su cuento "Anastasia», donde una mujer llega a la muerte a causa de la intransigencia de la sociedad, que le endilga un embarazo causado por el cura párroco, quien a su vez tiene que abandonar el pueblo a pesar de su inocencia por las elucubraciones erróneas y mal intencionadas de la comunidad.

El fenómeno de la proliferación de voces narrativas continúa al filo del fin de siglo. Varias autoras que venían escribiendo desde los años 80 y no habían concretado la publicación de su obra por razones económicas, logran finalmente dar a conocer su producción. Tales son las hermanas Mabel Pedrozo y Amanda Pedrozo quienes publican en conjunto el libro Mujeres al teléfono (1997), donde puede palparse el fuerte cuestionamiento a una sociedad donde la doble moral y la corrupción se han convertido muchas veces en moneda corriente.

La escritora Lita Pérez Cáceres (1940), inédita durante mucho tiempo, publica finalmente María Magdalena María (1997) haciendo un despliegue de humor, a través del cual manifiesta su protesta contra el orden es- tablecido. La rebelión de Pérez Cáceres es abierta y sin tapujos. En el cuento La carne de Carmela nos describe la conducta de una mujer sin prejuicios a la cual la sociedad tiene finalmente que aceptar tal cual es, luego de sus incontables aventuras, un casamiento por conveniencia del cual se evade por medio de una relación adúltera.

Una de las últimas autoras en manifestarse es Margarita Prieto con su libro de cuentos Tiempo de chivatos (1998), de sabor popular y aguda comprensión del alma campesina, a quienes se suman otras con obra individual inédita, nucleadas en su mayoría en el Taller Cuento Breve, y otras voces jóvenes, tal como la de Monserrat Álvarez con dos novelas cortas y varios libros de cuentos.

Así como la situación desventajosa de la mujer frente al autoritarismo de una sociedad castradora que funciona sobre el esquema de la familia patriarcal, y las denuncias contra la opresión en el marco de la dictadura stronista se han convertido en el ingrediente obligado de la liberación de gran parte de la literatura paraguaya escrita por mujeres actualmente, también se debe destacar el interés por la lengua autóctona, el guarani, y el fenómeno del bilingüismo paraguayo, asumido por la mayoría de las escritoras actuales.

El enfoque de las autoras al problema de la lengua sojuzgada, que subyace y se impone al español en el habla de la mayoría de la población paraguaya, es variado y disímil, tal como lo fue hace cuarenta años para los narradores varones.

El código utilizado es el español, pero se nota una ingente penetración del guaraní en el discurso narrativo, ya sea a través de frases enteras introducidas en dicha lengua y explicadas posteriormente en el contexto, como por la incorporación al discurso narrativo de términos y giros sintácticos del guaraní trasladados al castellano; sin olvidar la utilización del jopara, lengua híbrida, mitad español, mitad guaraní, o del castellano paraguayo que se impuso por medio de la oralidad para penetrar posteriormente la escritura. Si bien podría pensarse que este fenómeno tiene relación con la oficialización del guaraní, equiparado actualmente al castellano, me inclino a pensar que obedece más bien a la penetración de las autoras en la idiosincrasia de sus personajes, cuyos esquemas mentales obedecen frecuentemente a los patrones lingüísticos de su len-
La liberación de la mujer a través de la escritura RENÉE FERRER 
gua materna, el guaraní. Cuanto más rural o marginal es un personaje, más se incorpora el habla al discurso narrativo. $Y$ ese reconocimiento del guaraní como factor determinante de la personalidad ha dado por resultado la utilización de un lenguaje peculiar en consonancia con la procedencia y situación social de los personajes.

Si bien algunas escritoras se inclinaron por los procedimientos de interpolación o explicación de los vocablos dentro del mismo discurso, Margot Ayala de Michelagnoli optó por el registro del habla popular de los barrios marginales de Asunción, utilizado en su novela Ramona Quebranto (1989), donde desde el título podemos detectar la sintaxis guaraní, a pesar de la utilización de los vocablos castellanos. El significado del mismo es, trasladado a la sintaxis castellana, el quebrando de $\mathrm{Ra}$ mona, algo similar a lo que acontece con la estructura del posesivo en inglés.

Luego de este recuento bibliográfico y temático podemos aseverar que la mujer se ha ganado un lugar preponderante en la literatura paraguaya de hoy, y que su rebelión contra el esquema tradicional se manifiesta cada vez con mayor vigor por medio del oficio de escribir, donde el manejo del discurso narrativo, sea metafórico, sarcástico o irreverente, se utiliza como arma y como escudo, como carta de identidad y de reivindicación.

Para cerrar este panorama de la narrativa femenina en el Paraguay es interesante destacar el papel que le cupo a los talleres literarios de Hugo Rodríguez Alcalá, Carlos Villagra Marsal, Ester de Izaguirre, Jacobo Rauskin, Francisco Pérez Maricevich y Osvaldo Gon- zález Real en el descubrimiento de las voces más recientes de la literatura paraguaya.

Ya se ha mencionado la preocupación de las autoras con respecto a nuestras raíces lingüísticas. Si bien es cierto que el bilingüismo hispano-guarani ha condicionado preferentemente el discurso narrativo de nuestros escritores varones, no se puede dejar de señalar la voluntad de incorporación de la lengua soterada que manifiestan varias de las autoras mencionadas, así como la utilización del castellano paraguayo en el texto narrativo.

Nos complace constatar la abundancia de voces femeninas, muchas de marcado acento feminista, en la actual narrativa paraguaya, como resultado de una valoración de la mujer, que ha tomado conciencia de su derecho a dar testimonio de sí misma, de los otros y de sus circunstancias, desde un ángulo netamente suyo. El potencial existente en la voz de la mujer, que ahora asume su sexo y su género, y concomitantemente se libera, no puede sino enriquecer la literatura de cualquier región de la tierra.

Concluyendo se puede afirmar que, si bien la narrativa paraguaya ha sufrido un retraso inicial, careciendo de esa tradición centenaria que aureola a otras literaturas del continente latinoamericano, el actual caudal de escritores de ambos sexos, el ritmo de creación, la diversidad de temas, la persistencia en el rescate de la lengua autóctona como garantía de identidad cultural, y principalmente la irrupción decidida y fecunda de la mujer, permiten señalar que se está desarrollando en el Paraguay una narrativa medulosa que el tiempo se encargará de valorar. 
Profesor de español en la Ferris State University, en el estado de Michigan de Estados Unidos, es autor de varios libros y artículos sobre la poesía hispanoamericana contemporánea, particularmente la mexicana y la paraguaya. Así mismo ha residido y enseñado en el Perú, en México y en España. En 1997 le otorgaron una beca

\section{DOS EXTREMOS DE LA POESÍA PARAGUAYA: CARLOS VILLAGRA MARSAL Y JOAQUÍN MORALES}

Fulbright para dictar clases de la poesía posmoderna hispanoamericana en la Universidad Católica de Asunción, y para llevar a cabo investigaciones sobre la poesía paraguaya. A base de esta experiencia, Haladyna actualmente prepara una antología sobre la poesía paraguaya.

RONALD HALADYNA

El presente de la poesía paraguaya contemporánea ofrece una rica variedad de tendencias. Entre éstas, encontramos en un extremo la poesía vitalista y seguidora de los esquemas menos vanguardistas del siglo $\mathrm{XX}$ de Carlos Villagra Marsal, y en el contrario el rupturismo y la innovación trascendental que representa Joaquín Morales entre otros poetas coetáneos. Así, podemos situar dos obras como El júbilo difícil de Villagra y Postales desde Bizancio de Morales, como vértices extremos del amplio espectro de la poesía paraguaya actual.

\section{EL JÚBILO DIFÍCIL DE CARLOS VI- LLAGRA MARSAL}

\author{
AQUEL HUMO \\ Quemazón azul \\ de octubre \\ veladura repujada \\ estás más cerca \\ de mi palabra \\ que del horizonte viejo.
}

Pilar de humareda capital

soy tu trasunto

una refracción apenas

de tu empeño:

brasa dispuesta.

rojizo lenguaje codicioso

luego morosa vehemencia

niebla seca

ciego ascenso

y al fin disgregación

en el ensimismado

firmamento. (32)
Según algunos teóricos postmodernistas, el futuro de la poesía se encuentra irremediablemente en entredicho puesto que todo lo que se tenía que decir ya se ha dicho y que los poetas actuales - plenamente conscientes de su largo e ilustre ascendiente literario y, sin embargo, ansiosos de expresarse con originalidad - no pueden aspirar a más que asimilar la tradición y trascenderla con sus toques personales (léase «estilo»). Esta solemne y lúgubre perspectiva no toma en cuenta que a todo poeta se le apodera la irrefrenable pasión por inmortalizar sus vivencias en palabras, independientemente de lo que digan los teóricos. El júbilo difícil (1995) de Carlos Villagra Marsal se revela como otro argumento convincente en contra del supuesto fin de la poesía.

Si aceptamos que la metáfora se ha destacado en la poesía como la condición sine qua non, como la piedra fundacional en cualquier construcción poética - como sugiere Eduardo Milán (6) - el edificio poético de Villagra Marsal ha sido construido con cimientos sólidos y hermosos. Aunque El júbilo difícil se empeña en desempolvar todos aquellos aspectos poéticos que hoy comúnmente han sido descartados pero que antaño se consideraban elementales - métrica, rima, ritmo, elocuencia, brevedad, gracia, sutileza, así como temas y lenguaje decorosos - la metáfora sobresale por su ubicuidad y la imaginativa atención a su acabado. De especial interés es la combinación de varias metáforas consecutivas en serie, como se aprecia en el poema ya citado, «Aquel humo». Metáforas de apenas dos o
Dos extremos de la poesía paraguaya: Carlos Villagra Marsal y Joaquín Morales RONALD HALADYNA 


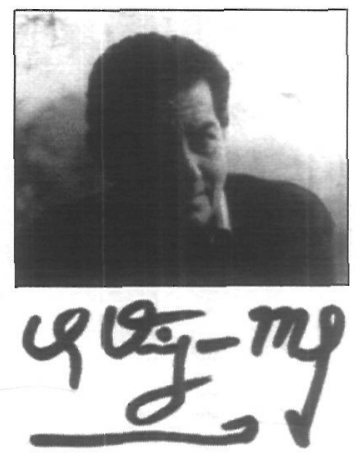

Carlos Villagra.
Dos extremos de la poesía paraguaya: Carlos Villagra Marsal y Joaquín Morales RONALD HALADYNA tres palabras renombran y giran alrededor de una sola imagen: «quemazón azul», "veladura repujada», «humareda capital» «brasa dispuesta», "rojizo lenguaje codicioso», «morosa vehemencia», «niebla seca», y «ciego ascenso». Más que diferentes enfoques de una sola realidad, he aquí las distintas perspectivas de un lenguaje virtual o inmanente. Según Ihab Hassan la «inmanencia», no debe entenderse con ningún sentido teológico, sino como «la capacidad imaginativa de generalizarse a sí misma en símbolos, intervenir cada vez más en la naturaleza, actuar sobre sí misma a través de sus propias abstracciones y convertirse... en su propio medio ambiente» (traducción mía, 93).

El ambiente verbal se demuestra repetidamente en El júbilo difícil tanto para seres vivos como para las cosas y los fenómenos naturales. La luna: «el cachorro de luna»; «flameante carnicero nuevo»; "vástago de león azul»; «creciente animal» (35). El paisaje: «invitación trascordada / promesa de sesgado cumplimiento» [...] Oh desmemoriado / paraje resuelto / oh contemplado aroma / oh denominador del tiempo / oh distancia curti$\mathrm{da} /$ oh digitación de cielo / oh vasija de la intemperie / oh cambiante paroxismo desierto» (40). La lluvia: «pausa esmerilada, / ciudadela instantánea, / muralla levantada [...] goteadora [...] garúa entrefina, / cerrazón, / soledad movediza [...] agua interior» (42-43). Este denso tejido metafórico genera una serie de imágenes que recalca el dominio que el poeta necesita tener sobre el lenguaje. El crítico Charles Altieri piensa que el buen poeta interpreta una experiencia en lugar de describirla. Así mismo, al reconocer que la experiencia consiste en palabras y no en ideas, «las mejores líricas evitan 'la discursividad ensayística' de los ensayistas en verso... y muestran la potencia del lenguaje de expresar lo que habíamos pensado inexpresable» (traducción mía, 5).

En la sección «Ciertos pájaros» se encuentran veinte poemas dedicados a pájaros peculiares al trópico paraguayo, todos identificados por sus nombres en guaraní. Este virtual catálogo ornitológico rinde tributo y, en efecto, exotiza especies que seguramente habitaban lo que hoy son las crecientes zonas urbanas del Paraguay. Aunque las descripciónes físicas de las especies - colores y forma del plumaje, pico, ojos y alas - están des- lumbrantemente logradas, también se agregan otras más inusitadas como sus acciones características: la trayectoria de su vuelo, el tono de su canción, sus hábitos culinarios, sus métodos de seducción o de engaño, su horario de actividad y de reposo y sus dones específicos, como sea el caso para cada uno. Estos retratos cuidadosamente pintados confieren una personalidad inconfundible a cada especie, las antropomorfizan, sobre todo cuando el poeta se dirige a todos los pájaros de «vos», sugiriendo hermandad con los amigos volantes así como una meticulosa e íntima observación directa o indirecta de su vida.

Pero hay otra hermandad en juego aquí: la que une textos de poesía y de las ciencias naturales; un fenómeno que ha acrecentado en años recientes y que tal vez tiene que ver con la revolución de la informática, la disipación de los linderos entre las disciplinas y la consecuente interdisciplinaridad, o tal vez la creciente concesión de que toda escritura es potencialmente material poético. En varios poemas sobre los pájaros y en uno sobre las frutas ("Jakarati'a») las citas usadas como epígrafes provienen de enciclopedias o de libros especializados y sirven en una capacidad aclaratoria, como si fuera para sentar una necesaria base de observación científica desde la cual la imaginación del poeta puede despegarse en vuelos de imaginación verbal. Es así que en poemas como «Doble loor del suruku'a», «Se yergue de amores desiertos la calandria» y «Preñado reposo augusto del taguato apyratî» las citas, como material extratextual en efecto se incorporan a lo textual, es decir, se integran como una parte indispensable de los poemas. La complementaridad parece ser el propósito de juntar textos científicos con textos poéticos, pero cabe señalar que la oposición de los textos nos obliga a reflexionar sobre el notable contraste en el uso del lenguaje para fines ostensiblemente distintos. El texto científico procura ser directo, escueto, exacto, claro y poco ambiguo con la intención de facilitar una representación de la esencia de una realidad. Este uso del lenguaje netamente pragmático cuenta con la supuesta transparencia del lenguaje y la consecuente claridad y eficacia de comunicación. Por el contrario, el texto poético no propone tanto la recreación del objeto, sino el uso del objeto como un pretexto para el recreo del lenguaje. La densidad meta- 
fórica, la inusitada sintaxis, el vasto vocabulario y el consistente esmero en la métrica y la rima: todo está diseñado para llamar la atención al lenguaje como un fin en sí y sólo secundariamente como un instrumento de comunicación. La ironía de la poesía como ésta es que no sólo se logra una representación eficaz, sino también se hace de una manera más divertida e inolvidable que cualquier texto científico.

En contraste con aquellos pájaros conocidos por la belleza de su plumaje o la singularidad de su canto, se ofrece una perspectiva distinta con las aves rapaces y de pillaje; pero la descripción de éstos se destaca por intencionalmente ignorar precisamente su característica más notable: su agresión. La sutileza predomina aquí: se menciona de paso su naturaleza agresiva y su potencia de devastación, pero se elude lo que potencialmente sería en un texto lo más dramático y explotable de su identidad biológica para concentrar en otros rasgos relacionados a su instinto mortífero. Las aves rapaces, conocidas por la velocidad de su vuelo y la manera en que agarran su presa a toda velocidad. Pero estos poemas evitan lo dramático y las expectativas más comunes al limitarse a sugerir sólo la violencia del acto mismo, dejando la parte más cruenta a la imaginación del lector. La voz poética menciona las víctimas del saqueo pero abrevia la descripción del momento más decisivo de su voracidad en poemas como, por ejemplo, «tukâ hovy»: «... sobrevienes y saqueas y te vas» (68); en «aka'ê hovy»: «turbas nido tras nido, más curioso que osado / y voraz más que pícaro» (74). Para el halcón «morotî», el poeta pinta un ambiente de inminencia: "y el asalto presumo: / el precipicio de tu incendio blanco...» (84); y para el «taguato apyratî» menciona su presa, pero omite la inevitable sangre: «Ejecutante sobrio del venado, / imparcial asesino del enjuto / tigrillo y del lagarto novelero» (86). La ferocidad del «ñakurutû hû» se sintetiza en sólo dos breves versos: «tomador / de carne oculta y lunas minuciosas» y «ávido sargento / y capataz del aniquilamiento» otra vez sólo sugiriendo su actividad nocturna sin representarla gráficamente. Pero el poema que mejor ilustra el arte de soslayar el aspecto más sangriento y más dramático de las aves rapaces es "Acometida del taguato'i»:
Con el silencio violento

de tu penacho azulejo

hincas y ejerces un viejo

embate oblicuo en el viento;

un choque, un destello hambriento

bastan; la sangre despena

tu sed, el aire refrena

su ardor o su sobresalto

y un vago plumón en algo

declara la muerte ajena. (71)

Se suele comentar que los medios de comunicación masiva en esta época han confundido el libre ejercicio de la expresión con el atrevimiento de decir o mostrar cualquier cosa (intima, violenta, monstruosa) de la manera más prosaica y obvia para bajarse comercialmente a los gustos públicos más accesibles y lo que más ha sufrido es la sutileza artística. Ahora con versos como los de «La acometida del taguato'i» tenemos el polo opuesto y se le obliga a uno a reflexionar sobre la identidad del posible público lector de poesía como ésta. Tanto su elegancia de estilo, como su sofisticado vocabulario y su complejidad métrica van a quedar años luz de distancia del alcance de todos aquellos lectores que no tengan una considerable base literaria.

Pero hay otro peligro respecto a un público potencialmente mucho más grande. Entre los lectores que no sepan guaraní, algunos sin duda van a quedar fascinados por la incursión de exóticos vocablos guaraníes en los poemas de El júbilo difícil. Estas palabras agregan una rica dimensión cultural a una poesía patentemente regionalista que se deleita en elogiar la flora y la fauna peculiares a este país. Además sirven - conscientemente o no- para oponerse a la creciente homogeneización de la cultura occidental y para recordarnos de nuevo que el bilingualismo y el biculturalismo también son aspectos insoslayables de la realidad paraguaya. Sin la ayuda de un ñe' eryru, tal vez los vocablos guaraníes provocarán en otros lectores una sensación de incompletez en su lectura que lastimosamente restará su aprecio por esta poesía. Dadas las circunstancias geográficas, culturales, lingüísticas, temáticas y estéticas, la inclusión de estos vocablos no sólo es apropiada, sino imprescindible porque la palabra justa es determinada por el específico efecto deseado y el contexto reinante. Reemplazar "ypekî sayju», por ejemplo, con «pájaro-carpintero-amarillo» resultaría

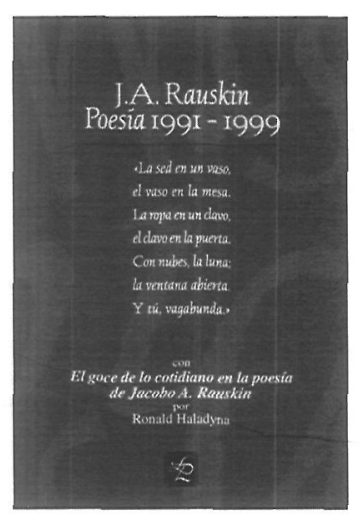

Rauskin. Portada.
Dos extremos de la poesía paraguaya: Carlos Villagra Marsal y Joaquín Morales RONALD HALADYNA 


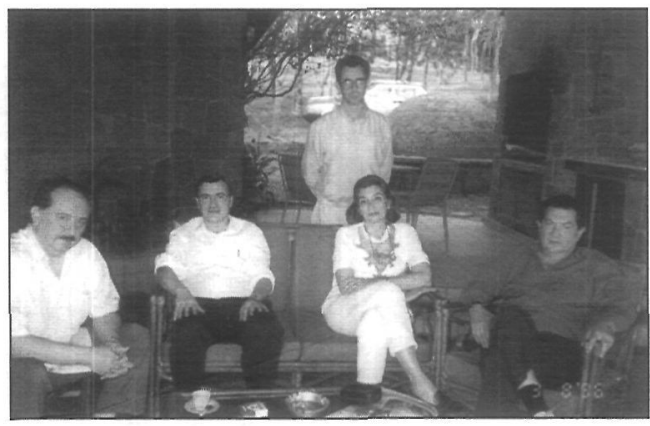

Última Altura. Helio Vera, José Vicente Peiró, Ana Mํㅡㅁorron y Carlos Villagra Marsal (sentados) y Guido Rodríguez Alcalá (de pie). (Foło: José Vicente Peiró).

1

«El que me entienda debe arrojar la escalera luego que por ella haya escalado. Él debe superar esas frases y luego verá correctamente el mundo». Traducción de Helena Rauskin.
Dos extremos de la poesía paraguaya: Carlos Villagra Marsal y Joaquín Morales RONAID HAI ADYNA contextualmente falso y estéticamente torpe. Aunque los títulos de los poemas dedicados a los pájaros y las frutas han sido acertadamente traducidos al castellano por el editor Raúl Amaral, muchos otros vocablos en guaraní necesitan semejantes traducciones. Ahora que se habla cada vez más de la inclusión de la poesía paraguaya en la «universalidad»-según una apreciación del mismo Amaral en su prólogo a El júbilo difícil (5) - siempre convendría en los futuros libros que tengan palabras en guaraní la inclusión de un glosario de equivalencias guaraní-castellano al final del libro, algo así como hacía el novelista peruano, José María Arguedas, para su frecuente uso de vocabulario quechua.

Hasta llegar a la penúltima sección de El júbilo difícil, no se concede nada al lado desagradable de la vida; no existe el menor interés ni el más leve indicio de lo feo, lo descompuesto, lo repulsivo, lo corrupto, lo injusto o lo irremediable en el reino biológico o mineral. Pero con la sección «Cantata del pueblo y sus banderas torrenciales», lo que aparenta prestarse para otro motivo de júbilo - la caída de la dictadura de Stroessner- pronto se convierte en una triste reflexión de la tiranía y en eso estriba la perfecta adecuación del título de este poemario. Los recuerdos amargos intervienen en todos estos poemas: «Asunción, ciudad vacía, / cansada de tanta peste...» (142); «a pesar de los golpes en la cara, / el grito no se esconde ni se mancha» (143); "los hombres que propone la luz adolescente / salvarán su camino del miedo y las basura» (144); «al joven impacto / del brazo sincero, / caerán las prisiones, /huirá el carcelero» (145); «huesos de Aurelio y Francisco, / dueños por fin de un rozado / arriba de las cosechas / y más allá del arado» (147). El júbilo por el derrocamiento de la dictadura se vuelve particularmente difícil cuando se toma conciencia de que la transición a la democracia no impacta sustancialmente la vida de los pobres:

\section{ESTE PAN EXIGIDO II \\ El cielo sucesivo \\ agrava el desamparo}

\begin{abstract}
y la antigua fatiga
hierve despacio;

condición del obrero

uncido a su trabajo:

en la mesa vacía,

se sirve llanto.
\end{abstract}

\author{
Mensualero del hambre, \\ albañil por un rato, \\ nocturno embarcadizo, \\ y ferroviario, \\ de pie, contra el que humilla \\ espaldas y salarios, \\ para honrar la esperanza \\ de un pan más alto.
}

\section{para Saúl Ibargoyen Islas}

La producción poética de El júbilo difícil abarca precisamente los años antes y después de la transición a la democracia; lo que resulta intrigante es el ordenamiento (nada cronológico) de los poemas que sitúa «Cantata del pueblo y sus banderas torrenciales» como la penúltima sección del libro. Salvo este agridulce «júbilo difícil», el suntuoso poemario se dedica exclusivamente a desvelar la belleza del mundo - los cielos y los fenómenos meteorológicos, los pájaros y las frutas regionales, los familiares $\mathrm{y}$ "poemas sobrevivientes» $-\mathrm{y}$ la celebra con todos los medios a su disposición: la esmerada selección de un vocabulario altilocuente; una rima cuidadosamente variada y consistentemente presente; una métrica impecable; una metaforización imaginativa y sutil; hasta la cubierta del libro - color terroso y deleite táctil-y las páginas de color crema con letra terrosa. Todo se junta en El júbilo difícil para integrar una majestuosa representación de la belleza de este mundo en una época cuando parece que cada vez más se nos extravia la capacidad de maravilla.

\section{UN BUZÓN LLENO DE SORPRESAS: POSTALES DE BIZANCIO DE JOAQUÍN MORALES}

¿Cuántos libros de poesía en lengua castellana empiezan con un epigrama del Tractatus Logico-Pbilosopbicus (1921) del filósofo austriaco Ludwig Wittgenstein y en alemán nada menos? Personalmente no tengo la menor idea, pero me aventuraría a adivinar que muy pocos. Encontré uno hace unos días en Posta- 
les de Bizancio (1984) del paraguayo Joaquín Morales ${ }^{1}$. Aunque la selección de un título apropiado para una obra literaria convencionalmente debería sugerir la esencia de la temática sin pecar de obviedad, el uso de un epigrama no siempre obedece los mismos criterios, razón por la cual esta elección de Morales me intrigó aún más después de leer este interesante libro.

Muchos años después de la publicación del Tractatus, Wittgenstein sugiere en su Investigaciones filosóficas (1953) que todas las palabras (significantes lingüísticos) están integradas en «juegos de lenguaje». Cada «juego» lingüístico es definido por un sistema de reglas que gobiernan la manera en la cual se usan las palabras dentro de ese contexto. En este sentido el lenguaje se parece a un juego - como el ajedrez - que tiene reglas que determinan cómo se pueden mover las piezas. Lo importante de esta teoría es que nuestros juegos modifican la manera en que experimentamos el mundo y la idea convenció tanto a teóricos como a escritores de este siglo a abandonar la perspectiva realista en favor de una perspectiva no realista o constructivista. Los constructivistas subrayan que es el lenguaje que da acceso al mundo; lo que nosotros llamamos el «mundo verdadero» no es más que una creación social siempre en evolución².

En las dos últimas décadas uno no se extraña al encontrar que los poetas no sólo tienen conocimientos de la filosofía moderna y de la teoría crítica sino que también incorporan en su poesía los mismos estilos y temáticas teóricas que absorben en sus lecturas. Por lo tanto hemos visto en años recientes evidencia de estas influencias en la obra de argentinos como Roberto Jurroz y Alberto Girri, en la del mexicano David Huerta y ahora en Postales de Bizancio.

Esta obra de Morales es, en gran parte, una poesía crítica. Aunque mucha poesía expresa implícita o explícitamente su propia arte poética, la poesía crítica dicta en forma concentrada la agonía de la insuficiencia de la potencia de las palabras para transmitir las ideas o del temor de no poder decir nada en absoluto ${ }^{3}$. Encontramos a lo largo de los 53 poemas de Postales de Bizancio varias referencias al uso de las palabras y del lenguaje que demuestran una constante preocupación y un asiduo cuestionamiento no sólo de la adecuación de las palabras para expresar la realidad, sino también de la posibilidad de una percepción sensorial del «mundo verdadero", de la formulación de ideas, de la veracidad de la memoria y de la re-creación de experiencias, recuerdos y conceptos en palabras. En esencia, se nos plantean en Postales de Bizancio muchas cuestiones axiales de las cuales se han ocupado los filósofos, teóricos y comentaristas durante gran parte de este siglo.

Tal vez su «Arte poética 1» resulte tan buen lugar como cualquiera donde empezar:

$$
\begin{aligned}
& \text { Palabras de papel, } \\
& \text { palabras de viento. } \\
& \text { Se van, se pierden, } \\
& \text { se olvidan, } \\
& \text { no sirven para nada } \\
& \text { y no dan de comer. (19) }
\end{aligned}
$$

Pero como lectores conscientes enfrentamos un dilema: ¿Debemos tomar estas palabras en serio si el poeta mismo no parece darles importancia a ellas? Mi respuesta es un enfático «sí» porque el poema está expresando - con un razonamiento nada postmoderno- un posible paradigma postmoderno, uno que refleja un cuestionamiento fundamental del logos que ha sido formulado desde el siglo pasado por Friedrich Nietzsche y en éste por Ferdinand de Saussure, Hans Georg Gadamer, Martin Heiddeger, Jacques Derrida y por cierto el ya citado Wittgenstein.

Pero también es posible contestar que «no» porque en realidad está expresando algo - con estas palabras - que parece muy cierto.

Postales de Bizancio es una poesía a punto de ser postmoderna. Varios poemas en este libro definitivamente no son nada postmodernos; pero en el arranque de otros se nota una tendencia hacia un lirismo coloquial de situaciones y tonos aptos para todo público. Pero en estos poemas la placidez del ambiente cambia repentinamente con la intromisión de lo que se parecería una sorpresiva falta de buenos modales. Es así que el lector experimenta una sacudida en poemas como «Li Po, muerto» en el cual entre las disculpas y el arrepentimiento del poeta ante el espíritu del célebre poeta chino cambia de opinión y promete emborracharse (40); o en «Inminencia de la casa» donde «volver a casa significa... el viejo placer de orinar en el jardín» (46); o en «Apuntes para una épica urbana» (66-67) en el cual el poeta confiesa que en su adolescencia se mas-
2

Stanley J. Grenz, A Primer on Postmodernism (Grand Rapids, Michigan: William B. Eerdmans, 1996) 112-114.

3

"Poesía crítica, un término acuñado por Octavio Paz para aquella poesía que que expresa escepticismo hacia el lenguaje y que cuestiona su propia construcción. Ver Thorpe Running, The Critical Poem, (Lewisburg, Pennsylvania: Bucknell University Press, 1996), 11.
Dos extremos de la poesía paraguaya: Carlos Villagra Marsal y Joaquín Morales RONALD HALADYNA 

G.E.M. Anscombe. (Frankfurt am Main: Suhrkamp Verlag, 1969), citado en Gerd Brand, Los textos fundameniales de Ludwig Wittgenstein. (Madrid: Alianza Universidad, 1975, 97-98).
Dos extremos de la poesía paraguaya: Carlos Villagra Marsal y Joaquín Morales RONALD HALADYNA turbaba y se enamoró de una tía solterona; o como vemos en "Ratones en el piano», donde utiliza un raticida para asegurar el éxito de un concierto del «lirismo de Liszt» (68). La inclusión de actos escandalosos irrumpe así en los momentos menos esperados sugiriendo que en el ámbito de los poemas, tal como ocurre en la vida, todos los registros de comportamiento pueden presentarse sin la menor advertencia. Estas sorpresas exigen al lector su constante vigilia porque algo sorpresivo puede ocurrir a la vuelta de cualquier esquina, sentando así la base de un importante consejo del postmodernismo: no tomar nada por sentado.

Otros poemas se concentran en los mismos temas que han ocupado la atención de los postmodernistas en los últimos treinta años: cuestiones relacionadas a la aprehensión visual, la percepción y el olvido, la metapoesía, la fenomenología, un cuestionamiento de la teoría de la correspondencia y temas nietzscheanos. La incorporación de estos tópicos en sí es sugerente de un texto postmoderno por las ideas radicales que proponen con respecto, por ejemplo, al lenguaje. En el poema «Contra las palabras» el poeta se arremete contra la arbitraria asignación de significado a las palabras, un tema central de pensadores desde Nietzsche hasta Derrida:

palabras, meras palabras,
fraguado polvo de ruido
...
Y esta confusión, sinceramente,
me preocupa:
pero la ordenación de las cosas
es insulto a cada una
si el pegarles rótulos
y barajarlos con cuidado
nos deja en las vitrinas un olor rancio,
sequedad de pergamino (18).

Tanto Friedrich Nietzsche como Ferdinand de Saussure han dejado sus huellas aquí. Aquél por su insistencia en respetar la infinita riqueza y variedad de la realidad, una realidad que sufre injustificables reducciones cuando se intenta representarla con palabras. Éste por su desvinculación de significante y significado; un ataque frontal contra la teoría de la correspondencia entre la palabra y la realidad que propone representar.

Nietzsche y Wittgenstein están dondequiera en esta poesía que toca lo fundamental del Tractatus - la relación entre realidad y lenguaje - como se evidencia en estos fragmentos de «Proyecto de fin de semana»:

Un mundo sin porqués ni desdecuándos, ni evidencia para ningún nombre ni nombres para lo que no tiene evidencias... ...

Todo enunciado

una generalización no comprobable, una aseveración presuntuosa, una apuesta para diversión de dioses aburridos (apenas habitantes de enciclopedias): en que no haya término de acción ninguna ni precedentes, ni tendencias, ni reminiscencia en que apoyar la sospecha de haber estado allí antes... (32-33)

Si bien Nietzsche apachurró la validez de los conceptos usados por los filósofos para establecer las «verdades» del mundo moderno, Wittgenstein posteriormente pisoteó la idea de que el uso del lenguaje surge por un encuentro trascendental del sujeto con un mundo objetivo. La oposición aquí a las generalizaciones y los conceptos; esta desconfianza en el lenguaje y en la confianza tradicional en su capacidad de re-presentar la realidad; todo refleja la filosofía y el tono de Nietzsche. El filósofo alemán no sólo negaba el afán del Occidente de crear conceptos con palabras; también creía que el lenguaje era la realidad y que todo lenguaje está al servicio de los poderosos de las sociedades que querían ejercer con él su voluntad de dominar. Son ideas seminales que siguen ejerciendo una enorme influencia en el pensamiento occidental del siglo $\mathrm{XX}$ y que han hecho eco en la literatura, aquí en la poesía de Joaquín Morales.

Unos años antes del Tractatus, Wittgenstein advierte en el Tägebucher que

«... comprendemos el mundo como sistema. Puedo reducir la descripción del mundo a una forma unitaria, colocando sobre él una 'red' como, por ejemplo, la descripción del mundo que hizo Newton. No hay que confundir esto con la comprensión» ${ }^{4}$.

He dicho que esta poesía es casi postmoderna porque parece estar en un proceso de transición. Como ocurre en la poesía del poeta mexicano David Huerta, las frecuentes incursiones de la problemática del lenguaje - central en el discurso teórico de los últimos vein- 
te años - en la misma poesía de Morales incide en una paradoja sin salida: la aparente inutilidad del lenguaje sólo puede ser comunicada con el mismo lenguaje. Comunicada, pero no demostrada todavía en la poesía de Joaquín Morales que sigue desenrollándose de una manera tan clara y convincentemente que parece desmentir sus propias afirmaciones.

La presencia de Wittgenstein (el de Investigaciones filosóficas) es notable especialmente en poemas posteriores que no iban a aparecer hasta la publicación de Muestra de poesía (Arandurã, 1995) como si el poeta quisiera poner en práctica la idea wittgensteiniana sobre el lenguaje como un juego. En unos fragmentos del poema «Hurras a Bizancio» ${ }^{5}$, encontramos un virtual paradigma del lenguaje en juego:

metahistorieta hiperculta post $(\mathrm{u})$ moderna semicomics megakitsch polidramática politraumática paraliteraria transretorizante intertextual antiparnasiana hipertrófica antipirética epigástrica protonocturna versificada profusamente anotada cuasi encantamiento y ensalmo celebratorio medio kachiäi de los decires cultos y de nación, glosas floriculturales y musicales ortopedias de robusta poética bien temperada al uso de los antiguos maestros de capilla flamencos y borgoñones y grecoguaraníticos puesta en materia poética según la celebrada y gloriosa tectónica de la Casa Torta y el literario Mbaipy Parnasiano regados por abundante Zeitgeist de la mejor cosecha, id est Secunda Reconstructio... (45)

Según Wittgenstein, el uso del lenguaje constituye un juego, consistente sólo con las propias reglas establecida para los fines del juego, reglas siempre establecidas por los usuarios del mismo. Este torrentoso caudal de palabras de todo registro de Hurras a Bizancio - satirizando la exagerada sofisticación de los textos de teoría crítica, filosofía, historia y sociología - del «Newspeak» científico adoptado en los círculos humanísticos. No sólo se burla de tipos académicos como nosotros sino que, y más importante, demuestra gráficamente una conclusión fundamental de los filósofos y teóricos del siglo $X X$-algo que no le sorprendería a la gran mayoría de una población ya dolorosamente enterada de los abusos del poder- que las palabras sólo son palabras. Tras las máscaras de los textos de la sofisticación científica o humanística, de la grandilocuencia política, de la cuidadosa selección de «las noticias más importantes» por los medios de la comunicación masiva, las palabras - como diría Wittgenstein - están siempre en juego y los que establecen las reglas del juego - de acuerdo con Nietzsche - siguen ejerciendo su voluntad de dominio.

En un artículo anterior yo había mencionado que la poesía paraguaya sigue siendo dominada por la lírica de la tradición románticasimbolista, una opinión que todavía sostengo. Pero Joaquín Morales está abriendo a machetazos un camino por bosques desconocidos; una poesía interesante por la novedosa perspectiva que aporta; y prometedor porque hay mucho bosque verbal por delante. Con «Hurras a Bizancio» ha empezado a practicar lo que antes sólo presentaba como una posibilidad teórica. Que siga su exploración.

\section{BIBLIOGRAFÍA}

Amaral, Raúl. Prólogo. «La poesía natural y profunda de Carlos Villagra Parsal». El júbilo difícil. Por Carlos Villagra Marsal. Asunción: Don Bosco, 1995.

Altieri, Charles. Self and Sensibility in Contemporary American Poetry. Cambridge, MA: Cambridge UP, 1984.

Hassan, Ihab. The Postmodern Turn: Essays in Postmodern Theory and Culture. Columbus: Ohio State UP, 1987.

Milán, Eduardo. «Roberto Echavarren: Posiciones. El contexto general». Poemas largos. De Roberto Echavarren. Montevideo: Arca, 1989. 5-13.
5

Ver Muestra de poesía (Asunción: Arandurã; Montevideo: Banda Oriental, 1995). 

nacida en 1935. Es preferentemente narradora y dramaturga. Su producción narrativa es numerosa pero hasta la fecha ha editado seis colecciones de cuentos, $L a$ oscuridad de afuera (1987), Entre ánimas y sueños (1987), Demasiada historia (1988), Efectos especiales (1989), Preludio con fuga (1992) y Presentes anteriores (1996). En novela, es autora de Los fantasmas no son como antes, Juicio a la memoria y Desde cierta distancia, pero sólo ha publicado Nocturno para errantes eternos (1999), Premio Gabriel Casaccia. Como teórica, participa con regularidad en los congresos de LASA.

\title{
EL PUNTILLISMO NARRATIVO EN LA OBRA DE GABRIEL CASACCIA
}

\author{
SARA KARLIK
}

Alguien lo llamó «el novelista del pueblo», tal vez por esa característica suya de adentrarse en la piel de los personajes, sobre todo de sus novelas, y explotar en ellos el sentido de la tierra, hasta que la muerte se lleva sus últimas ilusiones.

Casaccia nace en 1907 y emigra a la Argentina en 1935, después de la Guerra del Chaco. En 1963, le otorgan el premio Kraft en Buenos Aires por su novela La llaga. En 1966 obtiene el premio Primera Plana Editorial Sudamericana por su novela Los exiliados, mientras que Los herederos y Los Huertas fueron finalistas en otros concursos.

Casaccia ubica sus historias en Areguá, pueblo ubicado a $30 \mathrm{kms}$ de Asunción, en el silencio de sus más de 400 años de historia. Sus propias amarguras y esperanzas le hacen apelar a seres aparentemente rescatados de la mitología local. Descarnado en la percepción de sus compatriotas, no escatima esfuerzos para pintarlos como en verdad son en el proceso que inicia su caída y el terrible esfuerzo infructuoso por levantarse. La realidad es para el autor su lente identificadora.

La mayor parte de sus personajes está determinada por una fatalidad que parece acompañar todas sus narraciones. "Novelista de la degradación», lo denomina Rubén Bareiro, sobre todo al referirse a la atmósfera infernal de Areguá que tanto víctimas como victimarios ayudan a crear. Sólo en Los exiliados el escenario cambia, por necesidad de lo que se narra y de lo que experimentan sus personajes al adquirir la categoría de expatriados, sin por eso cambiar el tono intimista de la narración. El autor no escatima detalle o alcance acertivo para delinear lo que podría denominarse como puntillismo narrativo, el factor que mueve el interior de sus personajes con la intensidad de sus descripciones, pintándolos con colores que destacan y los identifican hasta crear los tipos necesarios para que produzcan en el lector la total identificación de ellos, alimentando la fantasía del lector e incorporándolo al mismo tiempo como personaje clave Consigue así el autor, que la imagen, la letra y los significados se fundan. Su realidad se vuelve la del lector.

Hombres, mujeres y fantoches (1929), única novela publicada en el Paraguay a los 22 años, así como El bandolero (1932), única pieza teatral, fueron criticadas por su lenguaje afectado y la poca profundización que hace de los personajes, y tildada como obra primeriza de un autor novel en el oficio. Es la presentación novelada de hombres y mujeres con inclinaciones $\mathrm{y}$ aprensiones corrientes, $\mathrm{y}$ de los fantoches, políticos corruptos que ilustran el período.

La lucha entre el bien y el mal en una atmósfera de tintes bíblicos ilustra el desarrollo de El bandolero, donde la cuestión religiosa y los símbolos adquieren ribetes de necesidad imprescindible en los ocho retablos de que se compone la obra. La atmósfera bíblica contrapone las figuras míticas de Caín y Abel.

Mario Pareda (1940) es una nowvelle en la que Casaccia cifró esperanzas, pero que resulta algo así como una obra frustrada, pues su protagonista siempre le persigue, viendo en él algo del Atilio de La Llaga. Es la búsqueda de sí mismo lo que insufla aire a Mario Pareda, 
haciendo eco de los problemas que lo atormentan, basado en un supuesto manuscrito entregado al autor que da origen a una ficción manipulada. Con todas sus debilidades, fue considerada la entrada de la novela dentro del ámbito local.

La Babosa (1952) es quizás la novela que más lo identifica y que le ha dado el renombre de novelista naturalista. En medio del tedio aplastante, decadente, deshumanizante, el protagonista, Ramón Fleitas, arribista y joven abogado, pretende desprenderse de su origen campesino casándose con Adela, la hija de un connotado abogado asunceno. Obligado a vivir en Areguá ve reprimido su deseo de convertirse en poeta. Ángela es quien lleva y trae la trama a través de su condición de «babosa», como la denomina el padre Rosales, algo que nunca la mujer le pudo perdonar. Ángela es una necesidad para Areguá, una forma de aguantar el tedio. Los mensajes anónimos, que sólo tienen el nombre de tales pues son fácilmente identificables, constituyen otra forma de capear el aburrimiento y resistir la convivencia.

Todos los personajes tratan de sacar partido de su posición o son sometidos por los deseos de otros más astutos. El amor carnal es la única salida para la mediocridad del lugar, que a su vez incide en la mediocridad de la gente. Por la misma razón, se vuelve costumbre, y es así que llega a ser natural la sumisión de la campesina que sirve en la casa como sirvienta. Fleitas se maneja entre la envidia y la frustración y por lo mismo cae en deudas de juego, una de sus pasiones, falta de discernimiento, la amistad con Espinoza, personaje oscuro que maquinará al final, la forma de quedarse con las joyas de Clara.

Las circunstancias convierten a todos en culpables y pecadores, igualados por la fatalidad. La astucia se vuelve un juego existencial cotidiano y es la que ofrece mejores dividendos. El padre Rosales equilibra de algún modo situaciones que a menudo escapan a su discreción de religioso.

El falso testimonio y la mediocridad se convierten en gimnasia y disciplina de sobrevivencia. El tiempo pasa, sin que nadie repare en su paso. El deterioro de Ramón Fleitas aumenta. Derrumbado, vuelve a ser el hombre rastrero de siempre. La hostilidad entre las hermanas Gutiérrez no cesa hasta la muerte de Clara, a quien Ángela hostigó con el pretexto

de cuidarla luego del violento robo del que fuera objeto por Espinoza.

«No es el novelista el que ha ido a la realidad que lo circunda; es la vida lo que ha penetrado en el orbe del novelista», afirma Casaccia cuando critican su inclemente escritura. Esta realidad lo lleva a desnudar el espíritu de sus protagonistas sin importar si son condenados o salvados por esa realidad.

En La llaga (1964) el detalle no cae en el exceso como en sus otras obras, haciendo más fácil y rápida la lectura. Siempre anteponiendo como fondo el pueblo de Areguá, cuenta el

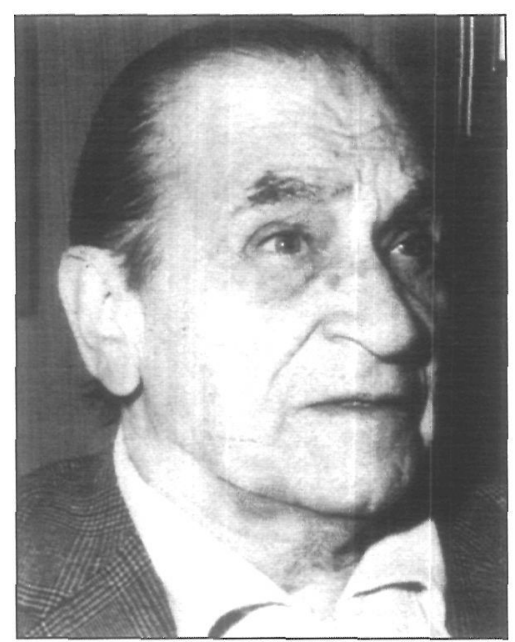

Gabriel Casaccia. autor la historia de Constancia y sus amores de viuda con Gilberto - mismos personajes que reaparecen en Los exiliados-, del temor de la mujer de envejecer, perdiendo su atractivo. Se apela a la intriga, lo oculto, la persecución, la denuncia en medio del desarraigo de la pasión amorosa o la exacerbación de ésta, el abandono, la supremacía del hombre como parte fuerte y decisiva en la relación de pareja. La cuestión política, el incesto amenazante, el conflicto madre-hijo, la soledad, la muerte, son los que mueven la trama.

La trama de Los exiliados (1966) transcurre en Posadas, Argentina, ciudad fronteriza separada por el río Paraná. Personajes como el abogado Rolando Gamarra, Etelvina su mujer, Leoni el hijo, Graciela la hija, se mueven dentro de la atmósfera del exilio y achacan sus problemas a las consecuencias de la situación en que se encuentran. Gamarra y Etelvina son propietarios del Hotel Guaraní.

Gilberto Torres, aparece como pintor; Ramón Fleitas, en La Babosa, es el símil de Gilberto Torres. Los exiliados viven pendientes de lo que ocurre en Asunción y la radio se convierte en un elemento aproximador. $\mathrm{La}$ conspiración deviene en obsesión de cambios. El mito del regreso, mantiene la ilusión.

El prostíbulo de Valentina - «la Polaca», como la conocen - es el refugio donde la pena busca consuelo. Dionisio - Leoni-, hijo de Gamarra, concubino de la Polaca, le robará sus joyas. Pasiones de toda índole se desencadenan en el burdel. No sólo el burdel prostituye, sino también el destierro, el alcohol corre como elemento emancipador del alma, del ocio. Algunos personajes de La Llaga, reaparecen, como Constancia y Gilberto que conti- 


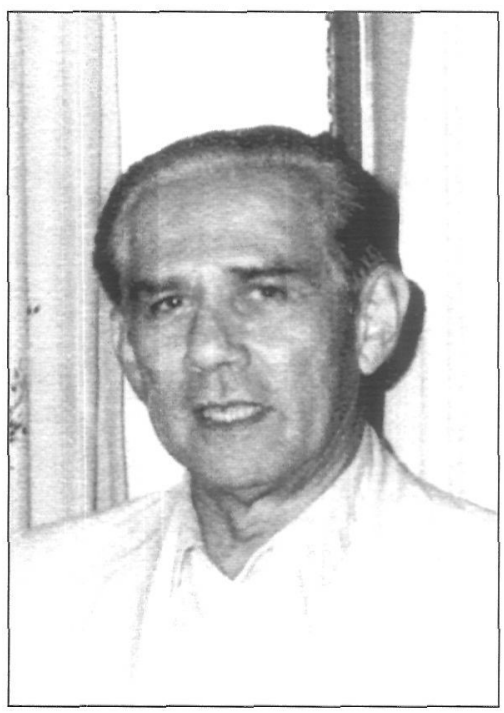

José Må Rivarola Maito (Foto de Manuel Rivarola). núan su deambular amatorio entrecortado por las circunstancias. Los personajes son perezosos, aprovechadores, colgados del exilio que los identifica y da pie a conductas de autodefensa o autojustificación. La sensación final es de derrota colectiva del deseo doloroso del regreso.

Como señala Casaccia cuando pinta los caracteres y pasiones de Los exiliados, no resalta el heroísmo del exilio, sino la caída del hombre. Hugo Rodríguez Alcalá sostiene que en la obra de Casaccia abunda, no lo que más ama el autor, sino lo que más odia. Otros agregan que es cruel, desprejuiciado, pero sobre todo valiente. Josefina Plá dice de Los exiliados que es «un documento despiadado sobre ciertos aspectos de la psicología colectiva». Casaccia tuvo la visión de proyectar Areguá con su envoltura candente, convertida en lugar de vacaciones para la gente de Asunción, en la idiosincracia de los protagonistas, llevándolos a extremos para probar su resistencia. Areguá es, para Casaccia, el lugar de sus recuerdos, de su infancia, de la adolescencia enfermizamente despiadada.

En Los herederos (1975), el mismo escenario se mantiene: Areguá. Al decir de Francisco Feito, los protagonistas de Casaccia son personajes tipo. Se repiten en sus escritos para diseñar distintas historias. Con la caída del Partido Liberal en 1941, el exilio acecha y los desbordes también. No sólo el calor agobia, sino la sensación de inseguridad, la delación. Areguá se convierte en el refugio de familias acomodadas, confinadas por las malas rachas de la fortuna. $O$ al confinamiento político causado por el gobierno de turno. Para muchos, la política se vuelve una suerte de acomodo. "Los eternos herederos de la debilidad», dice el padre Esquivel, también involucrado en conspiraciones que tendieran a producir cambios sociales y económicos. Cambia la trama, pero los personajes tipo permanecen. El cura, como una de las autoridades del pueblo. El atropello sexual de los patrones a las domésticas. Se intuye, se cavila, se sospecha sobre sombras con aspecto de hombres y de nombres que no son dados en herencia porque los amores eran de paso. Los hijos bastardos, bastante numerosos, quedan a merced del recuerdo futuro que los absolverá.
Florino Villalba, activista político de la oposición, vive con revólver en la cintura noche y día y miedo de acabar baleado por los "guiones rojos», bandas de adictos a ultranza del Partido Colorado surgidos con la revolución de 1947. Débil y temeroso, abandona la empresa de Octavio, su hermano, de «volar el Palacio de Gobierno con toda la basura adentro», como dice, por lo que la acción no logra concretarse. Al sumarse otros al intento, éste fracasa, sale a la luz y el comisario del pueblo, Filomeno Maldonado, junto con los guiones rojos locales, asesina a Octavio. El deseo de cambio está siempre presente en el espíritu paraguayo, constituyendo una seguidilla de atentados, asaltos $y$ asesinatos que nunca se aclaran.

Indalecio Rolón, el médico psiquiatra, también confinado por motivos políticos, hombre de gran cultura, maneja varios idiomas, sin por eso dejar de hablar un perfecto guaraní. El cambio de partido político, para él, es una forma de capear la situación indecorosa a la que había sido reducido. Termina siendo colorado. Nombrado director del Manicomio Nacional, cae en desgracia al ser acusado de violar a una interna de 14 años. Queda cesante, pero logra un puesto como médico rural en Areguá. Mantiene una relación con su vecina, Adelina Huertas, personaje que se vuelve a encontrar más tarde como protagonista principal de la novela Los Huertas. El deseo de ser trasladado a Asunción, le hace actuar irracional y rastreramente. Casimiro Huertas, hermano de Adelina, es un personaje conflictivo, lleno de aprensiones y angustias sobre las dudas que lo aquejan sobre si los dos hijos que tuvo su madre antes de casarse con Huertas fueron producto de la violación de que fue objeto por unos «cambás» de las tropas brasileras que ocuparon el Paraguay después de la guerra del '70. También lo perturba el no haber podido sacarle a su hermana Adelina el nombre del padre de Remigio, el hijo que ella tuvo. Acosado por sus perturbaciones, sostiene una situación de dependencia con su tía Gervasia, hermana de su padre, con quien habría mantenido relaciones. Casimiro Huertas, con todo, es un hombre virginal de alma que desea expiar sus pecados y los de los demás; idealiza la muerte y termina suicidándose. Sintetiza para Casaccia la idiosincracia del paraguayo en sus decepciones existenciales, en su deseo de cambiar una realidad que l puntillismo narrativo en 1
obra de Gabriel Casaccia SARA KARLIK 
lo involucra y consume. Todo su inconformismo lo concreta en la eliminación de sí mismo como salida decorosa.

Los herederos pareciera convertirse en un hito: el pasado que presenta ancestros que quizás destacaban por la no injerencia en el vicio, los herederos que no pudieron evitarlo y la sensación de esperanza de un porvenir en que el espíritu sano pudiera imponerse, como nudo temporal que circunscribe la existencia.

Tiempo-soledad-muerte es la trilogía que persigue a los protagonistas de Los Huertas, última novela de Casaccia publicada postumamente en 1981, un año después de su muerte. No tuvo, al igual que La Babosa en su momento, una crítica positiva.

Mario Pareda, abogado de empresas extranjeras, Filomeno Maldonado, el comisario de nueva aparición, Florino, el confinado político, y otros personajes, protagonizan esta novela. Florino y Adelina son amantes y protagonistas, desesperados por su mutua necesidad y por las odiosidades de las familias a las que pertenecen: los Villalba y los Huertas. Cuando Octavio es muerto por Filomeno Maldonado, Florino está a punto de caer en la redada. Rolón, que antecedió como amante a Florino, es quien le ayuda a escapar.

La novela se centra en Adelina Huertas, última heredera de la familia, en sus arrepentimientos y también obligaciones como heredera final, viviendo en un pasado con cargo a un presente de tedios y remordimientos y de apelación a las glorias anteriores. Florino resiente su condición de fracasado y vive con la ilusión de lo que pudo haber sido su destino si el coronel Evaristo Gavilán, en la revolución de 1947, no hubiese demorado el ataque a Asunción, postergando la orden que había recibido. De no haber ocurrido ese acontecimiento, su partido, el liberal, estaría en el gobierno y él en una posición de privilegio.

En Adelina Huertas perviven sus muertos y su espíritu es consolado por el alcohol. Se llega a hacer culto del linaje, de la virtud, de la tradición, en medio de rencillas que el tiempo no amansa y de recriminaciones continuas que tienden a delimitar posiciones sociales.

Remigio, el hijo oculto de Adelina Huertas, sale a la luz cuando se presenta con una orden judicial, mal habida, en la presunta casa de Casimiro Huertas, que ella ocupa, para reclamar la propiedad, el dinero y otras pertenencias, pues en el testamento de Casimiro aparece como hijo de éste. Todo se desmoronará de ahí en adelante para terminar con el suicidio de Adelina, mientras manipula el revólver que perteneció a Casimiro. Florino acaba mimetizado con los Huertas, en medio de la decadencia de las cosas.

Dos libros de cuentos le fueron publicados a $\mathrm{Ca}$ -

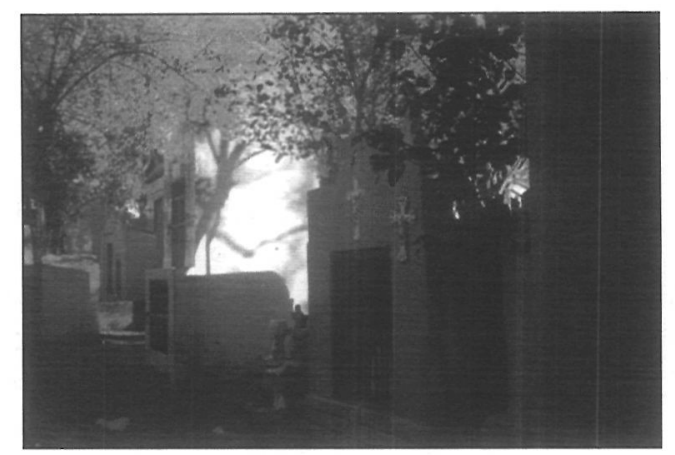

Cementerio de Areguá. (Foro: Mar Langa). saccia: «El guajhú» (1938) y El pozo (1947). En «El guajhú» (el aullido), que da el título a uno de sus libros, narra la historia de dos hermanos de madre, Tomás y Ceferino, de sus antagonismos. El perro aúlla por la muerte de su amo Ceferino, muerte que se atribuye a Tomás. La eterna lucha entre el bien y el mal, Caín y Abel, el hombre y su conciencia.

Otros cuentos de Casaccia, como «El Mayor», «Ciriaco», «La sortija», resaltan la indefensión del débil frente a la prepotencia del más fuerte, en tanto «La amberé» (la lagartija) y «La pora», lo vuelven a los mitos y leyendas que conforman su inquietud narrativa. La fatalidad y el destino conducen la trama de «El pozo». El autor maneja situaciones que resaltan frustraciones o delirios, haciendo del lenguaje preciso, insistente en el detalle, acucioso en el reborde con que remata el detalle, su característica definida. De pronto, también cede a la atracción del realismo mágico. La muerte es su aliada para fraguar el dramatismo de algunas situaciones. El sueño liberador es recurrente en sus cuentos. Otros cuentos aparecen entre 1925 y 1970. En «A ratos perdidos», los horrores de la Guerra del Chaco se manifiestan de forma velada, poéticamente, como evasión necesaria, búsqueda de lo que no se tiene a mano, que está en otra parte. «El hombre de las tres $\mathrm{A} » \mathrm{y}$ «El sueño del revolucionario» se vinculan en la trama en la que gobiernistas y revolucionarios se confunden. El autor se adentra en la psicología torturada de los personajes, o en las pesadillas torturantes que los persiguen con la facilidad que supone la mimetización por la comunión de problemas. La asociación con el autor es irremediable.

Leer a Casaccia deja al lector, a menudo, a bout de souffle, traspirando ante la profusión de detalles y de información. Recurre a frases en guaraní para redondear el delineamiento

El puntillismo narrativo en la obra de Gabriel Casaccia SARA KARLIK 
que hace del paraguayo y transforman en el mejor transmisor de su mensaje.

Casaccia conoce lo que narra y tiene la habilidad de involucrarse y también hacerlo con el lector en los problemas que plantea, entiende el proceder de sus protagonistas, y les ayuda a delinear sus traumas con su omniscencia a menudo abrumante, puntillosa, extrema hasta el agotamiento. Saca a la luz las falencias y virtudes del hombre, que probablemente son las mismas que acosaban al autor. Casaccia diseña una época y transforma a los protagonistas asistidos por la realidad aplastante dentro de la existencia reducida por la imposibilidad de elección, característica que subraya su obra y la conforma como unidad. Sus personajes tienen un hilo común: van perdiendo talla para acabar derrotados, característica recurrente que quizás se convierte en su sello. El tiempo, en Areguá, se centra en los cambios de sus moradores, los que entrelazan las novelas de Casaccia y las unifica formando un todo.

Es innegable la influencia de Zola en la presentación de un naturalismo en el que los personajes van delineándose psicológicamente, sin perder detalle de sus caracterizaciones, utilizando el mismo puntillismo de sus descripciones narrativas.

En la narrativa de Casaccia generalmente se aprecia que el autor hace un balance de los males del hombre y su repercusión en el alma. De ahí su universalidad. Casaccia, como un Dostoievsky latinoamericano, los somete a una expurgación que acaba por reducirlos psicológicamente, tratando de mostrarlos en su desnudez. El mito recrea la remembranza y la idealización de personajes y momentos. Para Casaccia, Areguá es el universo infantil, la unidad que representa el todo paraguayo. 
Es profesora de Lengua y Literatura Española. Forma parte de la Unidad de Investigación de Literatura Hispanoamericana de la Universidad de Alicante. Ha publicado más de una cincuentena de artículos de crítica literaria. Su tesis doctoral, Guido Rodríguez Alcalá en el contexto de la narrativa histórica paraguaya (2001), ha sido editada en formato digital. Además, es autora del libro Del franquismo a la posmodernidad: la novela española (1975-1999) (2000 y 2002). En la actualidad, prepara un libro sobre la interinfluencia de la historia y la literatura en Paraguay; y ultima las correcciones de Literatura española: de la transición al nuevo milenio, escrito en colaboraciôn con Ángel L. Prieto de Paula.

\author{
MAR LANGA PIZARRO
}

No veo más camino para el novelista nuestro en este umbral del siglo XXI que aceptar la muy honrosa condición de cronista mayor, Cronista de Indias, de nuestro mundo sometido a trascendentales mutaciones.

Alejo Carpentier, La novela latinoamericana en vísperas de un nuevo siglo.

Hasta bien entrado el siglo XX, la narrativa paraguaya está marcada por el retraso: es un género que nace tarde, que acoge las tendencias universales cuando en otros países ya están caducas, y que no alcanza su madurez hasta la década de 1950. De hecho, la primera novela aparecida en formato de libro en Paraguay, Zaida, del argentino Francisco Fernández, es de 1872; y, hasta 1905, fecha de la publicación de Ignacia, del también argentino de origen pero paraguayo de adopción José Rodríguez Alcalá, no se puede hablar de la existencia de una novela paraguaya. Además, las primeras obras narrativas capaces de interesar a la crítica y a los lectores internacionales son fruto de autores que, por razones políticas o económicas, abandonaron Paraguay a partir de la guerra civil de 1947.

Los que permanecieron en el país durante la larga dictadura stronista (1954-1989) se enfrentaron a múltiples dificultades para actualizar la prosa de ficción: al ostracismo se sumaban el desprestigio y la persecución de las actividades intelectuales, y la imposibilidad de publicar. Sin embargo, en los años finales del régimen stronista, la puesta en marcha de algunos proyectos editoriales animó a los escritores. En ese contexto, la prosa paraguaya se diversificó, y trató de adoptar procedimientos técnicos innovadores. Como ha sucedido en otros países con gobiernos totalitarios, al endurecerse la censura de los medios de comunicación, la literatura se convirtió en un susti- tuto de los mismos. La acogida de los lectores (aunque no fuera masiva, dada la escasa población del país y sus problemas socioeconómicos) favoreció la proliferación de narraciones literarias que reflejaban la realidad contemporánea (ya sea desde la perspectiva política, costumbrista o social), o indagaban en un pasado que, en buena medida, podía explicar el presente.

Esta última tendencia resulta especialmente interesante porque supone que, por primera vez en su historia literaria, la prosa de Paraguay desarrolla sin decenios de retraso la corriente que está triunfando en el resto del continente. Hablamos, claro está, de la «nueva novela histórica hispanoamericana», llamada así desde el estudio de Seymour Menton, La nueva novela bistórica de la América Latina, 1979-1992. Como novela histórica, el subgénero es un híbrido en el que la exposición de los hechos pasados se aborda desde las convenciones literarias. La novedad a la que hace referencia su nombre radica en el modo de plantear esos hechos, que se refleja en los recursos narrativos utilizados. Para entender esas transformaciones, conviene que recordemos el origen del género, y que tratemos de definir sus dos ingredientes (novela e Historia).

Según estableció Lukács (1976) en su célebre estudio, la narrativa histórica surgió a finales del siglo XVIII, como consecuencia de la Revolución Francesa (que favoreció el desa-
El novelista paraguayo como re-escritor de la Historia

MAR LANGA PIZARRO 


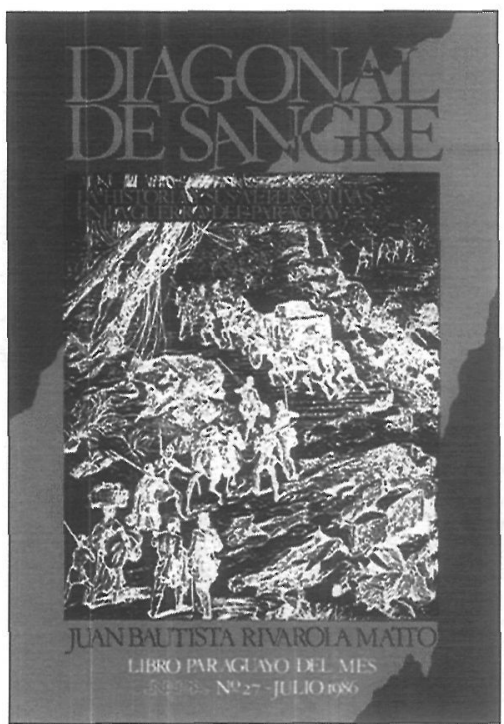

Diagonal de sangre. Portada. rrollo de la burguesía) y del Romanticismo (que propició el sentimiento popular de ser parte de la Historia). El esplendor de esta tendencia, a principios del siglo XIX, coincidió con el nacimiento de los nuevos estados hispanoamericanos, y ayudó a la construcción de sus identidades nacionales. No sucedió así en Paraguay, ya que el país llegó a la Independencia (1811) sin haber formado una elite cultural: la inexistencia de metales preciosos hizo que la Corona española nunca se ocupara en exceso del territorio, al que se negó la fundación de una Universidad para la que los propios ciudadanos recaudaron fondos en 1754 y en 1788 (por eso, Paraguay no tuvo Universidad hasta 1889). Además, el fracaso de la Revolución de los Comuneros (1735) supuso un fuerte golpe para la aristocracia local; y la expulsión de los jesuitas (1767) dejó a esta colonia sin prensa. Ya en la etapa independiente, la dictadura de Francia (1814-1840) cerró el país, e impidió toda actividad artística. Las esperanzas que se forjaron con la relativa apertura del gobierno totalitario de Carlos Antonio López (1842-1862) se truncaron con la Guerra de la Triple Alianza (1865-70), que enfrentó a Paraguay con Brasil, Argentina y Uruguay durante el mandato de su hijo, el mariscal Francisco Solano López (1862-1870). Acuciados por la urgencia de reconstruir el país tras la contienda, los intelectuales de la posguerra volcaron sus esfuerzos en consolar a sus compatriotas por medio de la poesía, y en elaborar un tipo de ensayo "historiográfico» que cumplió una función similar a la que había desarrollado la novela histórica en otros países del entorno.

Y llegamos así a la necesidad de precisar qué son la historiografía y la novela, para ver sus diferencias y sus puntos de encuentro. En la última edición del diccionario de la RAE (2001), corresponden tres acepciones a la entrada «historiografía»: «arte de escribir la historia», «estudio bibliográfico y crítico de los escritos sobre historia y sus fuentes, y de los autores que han tratado de estas materias» $\mathrm{y}$ "conjunto de obras y estudios de carácter histórico». Por su parte, la «novela»es, según su primera definición, una «obra literaria en prosa en la que se narra una acción fingida en todo o en parte, y cuyo fin es causar placer estético a los lectores con la descripción o pintura de sucesos o lances interesantes, de carácter, de pasiones y de costumbres»; y la "novela histórica», "la que desarrolla su acción en épocas pasadas, con personajes reales o ficticios».

Por tanto, la historiografía y la novela histórica coinciden en su cualidad de «arte» que utiliza la lengua para plasmar el pasado, y en la necesidad de estudiar la Historia para narrarla. La diferencia principal parece estribar en que la novela puede incluir acciones y personajes ficticios. Sin embargo, el límite entre lo real y lo «fingido» no resulta tan evidente ni en Paraguay ni en otros países. En el caso paraguayo, el principal de los autores de los «ensayos historiográficos» antes mencionados, Juan Emiliano O'Leary, no dudó en confesar: «he querido ser, ante todo, el animador [...]. Para devolver a la nacionalidad su fe perdida, para unificar su conciencia, para curarla de su derrota y de su derrotismo" (Apostolado patriótico). Con ese fin, tanto él como sus seguidores lucharon por convertir a los primeros gobernantes de la Independencia (Francia y los dos López) en héroes incuestionables, aunque para ello fuera necesario inventar hechos memorables, silenciar actos tiránicos, y revestir sus personalidades de las virtudes de los grandes hombres. Si los documentos no avalaban tales imágenes, los «ensayistas» se limitaron a ignorarlos o a destruirlos. Así, la historiografía se cubrió con ropajes de ficción, y esa ficción se institucionalizó como una verdad indiscutible, que se difundió en la prensa, los libros y los discursos de los dirigentes que, desde la Guerra del Chaco (1932-1935), se declararon herederos de los héroes consagrados. Sólo en los años ochenta del siglo XX, algunas obras historiográficas sobre Paraguay se dedicaron al «estudio bibliográfico y crítico de los escritos sobre historia y sus fuentes», en lugar de ponerse al servicio de los políticos que necesitaban el pasado para justificar el presente (es el caso de los trabajos de Juan Carlos Herken y María Giménez, Gran Bretaña y la guerra de la Triple Alianza, 1983; y Milda Rivarola, La polémica francesa sobre la Guerra Grande, 1988).

Como observó Valeria Grinbert (2001), a la tendencia positivista y objetivista de la historiografía del siglo XIX, correspondieron las
El novelista paraguayo com
re-escritor de la Historia

MAR LANGA PIZARRO 
novelas históricas realistas (o tradicionales), cuyo narrador extradiegético daba paso a protagonistas ficticios que convivían con personajes secundarios reales. Pero, cuando los escritores paraguayos del último cuarto del siglo XX abordaron la escritura del pasado desde la novela, los propios historiógrafos habían reconocido que la Historia nunca es objetiva. El reflejo de esa crisis en la concepción de la Historia es la novela histórica contemporánea, que percibe la realidad como algo complejo y subjetivo, incompatible con la dimensión mítica. Por tanto, la Historia oficial se cuestiona a través del relato literario, que multiplica los puntos de vista, y recurre a la ironía y a la parodia. Además, la «nueva novela histórica» humaniza a los grandes hombres; rompe el planteamiento cronológico mediante anacronismos, analepsis y prolepsis; introduce el monólogo interior; y hace de la memoria de los testigos un argumento de veracidad de lo narrado. De ese modo, la literatura se transforma en una vía para indagar en la verdad, aunque ésta se considere intangible. La consecuencia es el desarrollo de un punto de vista crítico: al investigar en el pasado, la novela histórica paraguaya contemporánea cuestiona la versión oficial de los hechos, manifiestamente revisionista; demuestra que los escritores de esa Historia oficial utilizaron la invención y los recursos literarios; y ofrece una nueva versión de los episodios fundamentales de la Historia del país.

Cronológicamente, el primer intento paraguayo de acercarse al pasado desde una perspectiva desmitificadora fue Yo el Supremo, novela que Augusto Roa Bastos publicó en Argentina, en 1974. Como es sabido, esta obra, que inauguró la tendencia conocida como «novela del dictador», aborda la figura de Gaspar Rodríguez de Francia, el primero de los dictadores paraguayos. Vilipendiado por su excesiva reglamentación de la vida pública y privada de Paraguay, que convirtió en imposible cualquier disidencia, Francia fue más tarde reivindicado por los revisionistas como uno de los "pilares de la patria». En la novela de Roa Bastos, sin embargo, el personaje es abordado sin distanciamiento épico, por medio de un lenguaje muy elaborado, que introduce técnicas constructivas novedosas, como la incursión de documentos reales y ficticios, y la multiplicación de voces narrativas.
A pesar del éxito internacional y de los numerosos estudios que se han dedicado a Yo el Supremo, parece que la obra fue poco leída en $\mathrm{Pa}$ raguay cuando se publicó. No puede olvidarse que la guerra civil de 1947 y la dictadura stronista obligaron a muchos paraguayos a instalarse fuera del país. Entre los escritores que se fueron y los que se quedaron se abrió una especie de vacío: los que emigraron conocieron las tendencias narrativas más innovadoras, experimentaron en sus obras, y publicaron con éxito, pero apenas llegaron a sus compatriotas; los que permanecieron en el país se refugiaron en una prosa tradicional cuando no propagandística, o engrosaron el llamado «exilio interior» de quienes carecían de la posibilidad de ver editadas sus creaciones.

Así, dentro de Paraguay, los intentos de reexplicar la Historia a través de la novela llegaron a mitad de los años ochenta, de la mano de autores como Juan Bautista Rivarola Matto (Asunción, 1933-1991) y Guido Rodríguez Alcalá (Asunción, 1946). El primero había comenzado su andadura narrativa durante su exilio en Buenos Aires, donde publicó Ybypóra (1970; edición paraguaya de 1982), una obra crítica y política en la que no faltaban alusiones a hechos históricos. Rivarola Matto se mantuvo dentro de los cánones formales de la narrativa histórica tradicional en la novela corta San Lamuerte (1985, Premio Gabriel Casaccia), donde relató la revolución de Chirife (1922); y en la trilogía compuesta por Diagonal de sangre (1986), La isla sin mar (1987) y El santo de guatambú (1988).

Diagonal de sangre es la primera novela histórica escrita por un autor paraguayo desde Yo el Supremo. En ella, Rivarola Matto trata de analizar la Guerra de la Triple Alianza con una objetividad casi ensayística, a la que contribuyen las numerosas fuentes documentales que se reproducen y se comentan. La isla sin mar, que se centra en los primeros años de la dictadura stronista, mantiene unas pretensiones de objetividad que no le impiden convertirse en una obra plenamente literaria, en la que la situación del presente se analiza como una continuación de lo acontecido desde la Guerra de la Triple Alianza. Por otra parte, esta novela,
El novelista paraguayo como re-escritor de la Historia MAR LANGA PIZARRO 


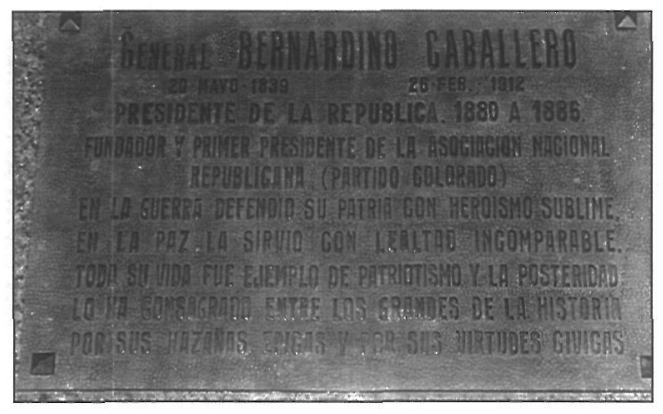

Placa del parque Caballero. (Foto: Mar Langa). que cuestiona la concepción de la Historia de los revisionistas y de la propia dictadura, encierra una fuerte crítica al modo en que Roa Bastos enfocó sus obras: en una evidente parodia, Rivarola introduce un amanuense que encuentra un manuscrito a partir del cual desarrolla la historia; y titula uno de sus capítulos «Borrador de informe» (como el cuento homónimo de Roa). En la tercera novela de la trilogía, El santo de guatambú, los elementos de la tradición oral, las opiniones personales y las fuentes documentales se dan cita en la figura de un personaje inventado, testigo de la vida del padre Fidel Maíz (uno de los más controvertidos actores de la guerra contra la Triple Alianza).

El otro autor mencionado, Guido Rodríguez Alcalá, comenzó su actividad literaria en el ámbito poético. Cuando apareció su primera novela, Caballero (1986), la prensa paraguaya recogió críticas y amenazas diversas: cuestionar la figura de Bernardino Caballero (que peleó junto al mariscal López, y fundó el Partido Colorado, el que más tarde respaldó la dictadura stronista) era un modo de atentar contra el pasado y el presente dictatorial del país. Porque los revisionistas habían hecho de Caballero el símbolo de la Reconstrucción emprendida tras la ya mítica guerra de la Triple Alianza; y Stroessner se había fijado en él para acometer la llamada «Segunda Reconstrucción».

Sin embargo, en contra de la versión oficial, el protagonista de esta novela (y de su continuación, Caballero rey, 1988) aparece como un pícaro, capaz de cambiar de amo cuantas veces sea necesario para acumular poder y dinero: su adulación a López y su astucia lo conducen al ascenso en el ejército durante la guerra; tras la contienda, su ambigua relación con los antiguos enemigos lo lleva de nuevo a Paraguay, donde abandona a los políticos que fracasan para aliarse con los que triunfan; $y$, ya en el poder, diversos negocios lo hacen asociarse con quienes se enriquecen a costa del país. Tampoco los personajes que rodean al protagonista salen mejor parados: Francisco Solano López es un loco sanguinario que aboca a su pueblo a la des- trucción, arrastrándolo a una guerra suicida; su concubina, Madame Lynch, una mujer autoritaria y ególatra, indiferente al sufrimiento ajeno; los miembros del Partido Colorado unos mercaderes incultos y maniqueos...

Caballero y Caballero rey abandonan tanto los espacios míticos y los juegos lingüísticos y conceptuales de Roa Bastos, como las pretensiones de objetividad y las intervenciones en el relato de Rivarola Matto: ambas están narradas por su protagonista, cuyo lenguaje plagado de incorrecciones, contradicciones e incoherencias contribuye a forjar una imagen negativa del personaje. Además, se introducen otras voces y documentos deliberadamente empleados para rebatir las tesis revisionistas. La manipulación del lenguaje, la ironía, la desordenada secuencialidad del texto, la inclusión de anécdotas y personajes inventados junto a los reales, obligan al lector a la distancia crítica: la novela y la Historia oficial se perciben como dos versiones de los hechos igualmente amañadas.

Si lo que cuenta el narrador intradiegético resulta poco fiable es porque no estamos ante el héroe que presentaron ensayistas e historiógrafos, sino ante un pícaro. Y como las novelas picarescas de las que toman algunas de sus características, Caballero y Caballero rey recurren al tono humorístico, a la estructura de episodios ensartados, a los títulos de capítulos con resonancias caballerescas; y a un protagonista que cuenta su historia para esclarecer la verdad, y hace gala de un comportamiento oportunista y delictivo.

Cada uno a su modo, Augusto Roa Bastos, Juan Bautista Rivarola Matto y Guido Rodríguez Alcalá, con las novelas citadas, fueron los impulsores de la narrativa histórica paraguaya actual, representada también por cuentos de base histórica como los incluidos en El ojo del bosque (1985), La doma del jaguar (1995) y El dragón y la beroína (1997), de Hugo Rodríguez Alcalá; Cuentos de la Guerra del Chaco y de otros tiempos (1987), de Osvaldo Jaeggli; La Seca y otros cuentos (Premio de la República 1986) y Por el ojo de la cerradura (Premio Los Doce del Año 1993), de Renée Ferrer; los excelentes relatos de Angola y otros cuentos (1984) y del libro digital La paciencia de Celestino Leiva (2000), de Helio Vera; «La odisea del regreso», de Dirma Pardo, incluido en el volumen 
colectivo Verdad y fantasía (1995); los tres cuentos históricos de Relatorios (1995), de Gilberto Ramírez Santacruz; los tres del mismo género que Maybell Lebrón publicó en Memoria sin tiempo (1992); y las múltiples recurrencias a la Historia en los relatos que el propio Guido Rodríguez Alcalá incluyó en sus libros Cuentos decentes (1987), Curuzú Cadete (1990), Cuentos (1993) y Cuentos de la Guerra del Paraguay (1995).

Además, los horizontes de la novela histórica paraguaya se han ampliado, para acoger temas que no atañen directamente al país: Adriana Cardús centró la novela Retrato de familia (1997) en la Inglaterra de principios del siglo XX; y Augusto Roa Bastos humanizó la figura de Colón en Vigilia del almirante (1992), que Giuseppe Bellini $(1997,491)$ calificó de «libro extraño, entre la ficción, la historia y el ensayo crítico, al fin y al cabo condenatorios, pues ve en Colón el iniciador de todos los males de América». Pero, sobre todo, la narrativa histórica paraguaya actual ofrece al lector una nueva versión de casi todos los momentos de la Historia del país, que los revisionistas habían manipulado previamente.

Así, la conquista española ha sido abordada por la novela histórica tradicional Jasy y Kuaraby (2002), donde Gino Canese hace una defensa indigenista; y por De lo dulce $y$ lo turbio (1997), donde Carlos Colombino usa los recursos de la nueva novela histórica para narrar el descubrimiento de América, mezclando el monólogo de Domingo Martínez de Irala con la voz de un narrador omnisciente, y la expresión poética con la influencia de Roa Bastos y las intertextualidades literarias. La etapa colonial es el argumento de Donde ladrón no llega (1996), con la que Luis Hernáez se acerca con maestría a la vida cotidiana en los últimos años de las reducciones jesuiticas; de Vagos sin tierra (1999, Mención Especial del Premio de Literatura), donde Renée Ferrer recrea la fundación de Concepción, en el siglo XVIII, con una documentación exhaustiva y un lenguaje de resonancias lorquianas; y de Paracuaria, el guión cinematográfico de Luis María Ferrer Agüero que relata la revolución de los Comuneros. Como ya se dijo, el gobierno de Gaspar Rodríguez de Francia sirve de argumento a Yo el Supremo, además de a numerosos cuentos. La guerra de la Triple Alianza se aborda en las antes mencionadas obras de Rivarola Matto y Guido Rodríguez Alcalá, así como en múltiples relatos; y en la novela Pancha Garmendia (2000), donde Maybell Lebrón aporta una sugestiva visión de la vida de la población civil durante la Guerra de la Triple Alianza. Y la transición del siglo XIX al XX, con sus continuos cambios políticos y revoluciones, es el tema de Caballero rey. Quedaba, por tanto, enfrentar el gobierno de Carlos Antonio López (desarrollado tan sólo en algunos cuentos) y el paso de la Colonia a la Independencia.

Esta última ha sido la labor emprendida por Guido Rodríguez Alcalá en la novela que ha publicado en 2002. Nos detendremos en ella, porque creemos que Velasco supone una inflexión en la obra del autor, que quizá sea reflejo de las transformaciones que está viviendo Paraguay. Velasco se acerca a la figura del último gobernador español, Bernardo de Velasco, depuesto en 1811. Conviene destacar que, a pesar de la afirmación anterior, esta novela tiene muchos puntos en común con el resto de la narrativa histórica de Guido Rodríguez Alcalá: una exhaustiva documentación que ha durado tres años; el recurso al narrador testigo y protagonista de los hechos contados, que vuelve a dar paso a otras voces; la ficcionalización de un personaje real que da título a la obra; la fusión de documentos auténticos con recreaciones imaginadas; y la elección de un momento histórico conflictivo, sobre el que existe una versión oficial aparentemente distante de la realidad (en esta ocasión, el periodo comprendido entre 1810 y 1812). Sin embargo, otros aspectos han cambiado: la prosa se torna ahora más clara y seductora; el personaje atrae la simpatías del lector, consiguiendo su complicidad; y, aunque no desaparecen los saltos temporales, la organización del relato es mucho más acorde con la sucesión cronológica de los hechos.

Tal vez estas transformaciones se deban a que la Historia que se narra en Velasco ha sido menos utilizada por los sistemas totalitarios que la relatada en sus novelas anteriores. Pero creemos también que dichos cambios no son ajenos a las circunstancias políticas de Paraguay: ya no estamos al final de la dictadura stronista (como cuando aparecieron Caballero y Caballero rey) sino en un momento de escepticismo y desilusión por los
El novelista paraguayo como re-escritor de la Historia MAR LANGA PIZARRO 
problemas que no ha resuelto la tan esperada democracia. Quizá por ello, la prosa de Guido Rodríguez Alcalá se ha serenado. Su revisión de la Historia es ahora una búsqueda de la verdad, no una necesidad política. Y el fruto de este cambio es una novela capaz de interesar a cualquier lector, porque incluso quien desconozca la Historia paraguaya podrá entender todos los matices del relato. Además, como el discurso del personaje carece de contradicciones e invita a la credibilidad, el distanciamiento del receptor es menor; $y$, aunque no se elude la crítica, la novela, más que hacer un alegato contra la versión revisionista, parece encaminada a conseguir el deleite literario.

Puede ser un indicio de que la vida paraguaya se va normalizando. En medio de las continuas crisis y dificultades, sus autores están dejando atrás ese pasado de desierto cultural al que tantas veces se han referido los críticos: las tendencias literarias universales ya no tardan decenios en cultivarse en el país; y existe un núcleo de narradores que publica asiduamente obras de calidad. Todo parece indicar que, conforme la sociedad civil vaya encontrando su camino, la literatura irá abandonando el clima de resistencia, y los esfuerzos de la prosa podrán concentrarse en la elaboración literaria. Si la historiografía paraguaya sigue dedicándose a buscar la verdad, algún día, dejará de ser necesario que los novelistas hayan de reescribir la Historia.

\section{BIBLIOGRAFÍA}

AÍNSA, Fernando (1991): «La reescritura de la historia en la nueva novela latinoamericana», Cuadernos Americana, nueva época, 28: 13-31.

AÍNSA, Fernando (1996): "Nueva novela histórica y relativización del saber historiográfico», Casa de las Américas, 202: 9-18.

ANDREU, Jean (1992): «Literatura paraguaya actual», Caravelle (Toulouse), 58: 169195.

Anthropos (1990): no 115: monográfico dedicado a Roa Bastos.

BAREIRO SAGUIER, Rubén (1984): «Estructura autoritaria y producción literaria en Paraguay», Caravelle (Toulouse), 42: 93-106.
BELLINI, Giuseppe (1997): Nueva historia de la literatura hispanoamericana, Madrid, Castalia.

CALVIÑO IGLESIAS, Julio (1985): La novela del dictador en Hispanoamérica, Madrid, Cultura Hispánica.

CASTRO, Claude (1997): Historia y ficción: "Caballero» de Guido Rodríguez Alcalá, Asunción, Don Bosco.

DOMÍNGUEZ, Mignon (coord) (1996): Historia, ficción y metaficción en la novela latinoamericana contemporánea, Buenos Aires, Corregidor.

FERNÁNDEZ PRIETO, Celia (1998), Historia y novela: poética de la novela histórica, Pamplona, Eunsa.

GARCÍA GUAL, Carlos (1998), «Explorar y reinventar el pasado», Babelia (Suplemento Cultural de El País), 22 de agosto: 8-9.

GRINBERG, Valeria (2001): «La novela histórica de finales del siglo XX y las nuevas corrientes historiográficas», Istmo, 2 (www.denison.edu/istmo).

Ínsula (1990): n 521: monográfico dedicado a Roa Bastos.

JITRIK, Noé (1995), Historia e imaginación literaria. Las posibilidades de un género, Buenos Aires, Biblos.

LANGA PIZARRO, M. MAR (2001): «Paraguay: narrativa e historia de una isla sin mar». En ALEMANY BAY, Carmen et alii (eds.), La isla posible, Murcia, Universidad de Alicante, 313-324.

LANGA PIZARRO, M. MAR (2002): Guido Rodríguez Alcalá en el contexto de la narrativa bistórica paraguaya. Edición en CD-Rom de la Fundación Biblioteca Virtual Miguel de Cervantes.

LUKÁCS, Georg (1976): The historical novel, Londres, Merlin Press (traducción: 1976, Madrid, Grijalbo).

MARCOS, Juan Manuel (1993): Roa Bastos, precursor del postboom, México, Katun.

MÉNDEZ-FAITH, Teresa (1997): Breve diccionario de la literatura paraguaya, Asunción, El Lector.

MENTON, Seymour (1993): La nueva novela bistórica de la América Latina, 19791992, México, F.C.E.

PEIRÓ, José Vicente (1999): «La evolución de la novela histórica paraguaya», Espaces Latinos, 169: 17-19.

PONS, María Cristina (1996): Memorias del olvido. Del Paso, García Márquez, Saer y 
la novela bistórica de fines del siglo $X X$, México, Siglo XXI.

PULGARÍN, Amalia (1995): Metaficción historiográfica: La novela bistórica en la narrativa bispánica posmodernista, Madrid, Fundamentos.

ROMERA CASTILLO, José - GUTIÉRREZ CARBAJO, Francisco GARCÍA-PAGE, Mario (eds.) (1996): La novela bistórica a finales del siglo $X X, \mathrm{Ma}-$ drid, Visor.
SPANG, Kurt - ARELLANO, Ignacio MATA, Carlos (1995): La novela histórica, teoría y comentario, Pamplona, Eunsa.

STECKBAUER, Sonja M. (ed.) (1999): La novela latinoamericana entre la bistoria y la utopía, Eichstätt, Universidad Católica.

TOVAR, Francisco (1987): Las bistorias del dictador. "Yo el Supremo» de Augusto Roa Bastos, Barcelona, Ediciones del Mall. 
Profesor de la Universidad Johannes Güttemberg de la Universidad de Maguncia (Mainz), donde ejerce como docente del Seminario de Filología Románica, es un profundo estudioso de la lengua guaraní. Sus actividades en el Seminario de Filología Románica se centran en la enseñanza del español, de las literaturas hispánicas y la cultura latinoamericana. Se interesó por el Paraguay y su cultura bilingüe gracias a sus estudios de las obras de Augusto Roa Bastos. Es uno de los mayores conocedores de la literatura en guaraní, además del estudioso más notable de esta lengua en Europa, hecho que revela la realización de varios diccionarios. Se encarga de una de las páginas web más nutridas sobre civilización guaraní y literatura paraguaya en general. Es autor, además, de numerosos trabajos sobre estos temas.

\section{LITERATURA PARAGUAYA EN GUARANí}

WOLF LUSTIG (MAGUNCIA)

El Paraguay es el único país latinoamericano donde la lengua de los «vencidos» ha mantenido su vigor hasta el siglo XXI. Es más: la Constitución de 1992 establece definitivamente en su Artículo 140: «El Paraguay es un país pluricultural y bilingüe. Son idiomas oficiales el castellano y el guaraní.» Pero sería un error pensar que la situación lingüística se deba a la importancia demográfica de la población indígena «mestiza» en esta céntrica república sudamericana: las comunidades indígenas guaraní-hablantes en su totalidad ya no corresponden a más del 1 \% de la población, pero casi la totalidad de los paraguayos conoce el ava ñe'ẽ («la lengua del hombre») y lo emplea parcialmente en la comunicación oral diaria (Steckbauer 1999, 386 ss.).

De ahí que, hablando de literatura guaraní y de literatura paraguaya, se imponga distinguir entre literatura (indígena) guaraní y literatura paraguaya en guaraní - aun a sabiendas de que la segunda comparte y hereda temas y problemas de la primera y que, en ambos casos, la aplicación del término literatura es algo problemática. Si bien hubo varios intentos de «reducir a escritura» el guaraní ( $\mathrm{Me}$ lià 1995, 90) desde el tiempo de los jesuitas, de hecho mantuvo su carácter básicamente oral (además de marginado) hasta las postrimerías del siglo XX. Si tomamos en serio el concepto de literatura paraguaya en guaraní como «arte de la palabra escrita por la cual el pueblo paraguayo expresa su cultura en su propia lengua», no sería exagerado decir que las últimas tres décadas son el período de emergencia, de gestación y (re)nacimiento de una nueva literatura sobre raíces antiguas.
Ya es un tópico hablar de la literatura paraguaya como terra incognita y del texto ausente como referencia simbólica a la falta de tradición literaria (Sánchez 1968; Roa Bastos 1984). Lo que es válido para la literatura en castellano lo es mucho más para su «otra vertiente» en guaraní, considerada como especie de subtexto de lo escrito en castellano. Pero también hay que tener en cuenta que lo ausente sólo ha sido el texto escrito y que la palabra viva guaraní-paraguaya ha pasado sencillamente desapercibida porque no había «letrados» que supieran escucharla. La salida del aislamiento, el acceso a la escritura le estaban vedados por obstáculos de variada índole, parcialmente exteriores y ajenos al fenómeno literario.

Antes de proceder a una muy reducida selección de autores y obras representativos de los dos grandes períodos por los que ha pasado el fenómeno que nos interesa, intentaremos echar luz sobre el contexto cultural, sociolingüístico e incluso político del que surge la voz guaraní en la literatura paraguaya.

\section{EL ARTE DE LA PALABRA INDÍGE- NA GUARANÍ}

Un rasgo intrínseco del arte de la palabra entre las etnias nativas guaraníes ha sido y sigue siendo la oralidad - ciertamente no sentida como limitación sino como algo susceptible de enriquecerse con formas de expresión no verbales como la música, la danza y los gestos. Lo que de este acervo ha pasado a las páginas de hermosas antologías (López Austin 1965; Bareiro Saguier 1980), originariamente se expresa en las formas rituales del 
canto sagrado y puede constituir - para quien sabe abrirse a su encanto - una entrada a un universo muy alejado de la cultura libresca de Occidente. Aunque en realidad es «de otro mundo», la oratura guaraní ha fascinado a los poetas paraguayos modernos y últimamente se ha convertido en una fuente de inspiración importante para la literatura paraguaya, sea que esta se exprese en castellano o en guaraní. Podemos citar como ejemplo el ya clásico himno sagrado mbya guaraní Ayou rapyta, en el que toma forma el carácter sagrado del lenguaje y la palabra (Cadogan 1992, 32s.):

\section{Ñamandu Ru Ete tenondegua}

[E] verdadero Padre Namandú, el primero, oyvára peteĩgui,

[de una pequeña porción de su propia divinidad, oyvárapy mba'ekuaágui,

[de la sabiduría contenida en su propia divinidad, okuaararávyma

[y en virtud de su sabiduría creadora tataendy, tatachína ogueromoñemoña.

[hizo que se engendrasen llamas y tenue neblina.

\section{Oãmyvyma,}

[Habiéndose erguido, oyvárapy mba’ekuaágui,

[de la sabiduría contenida en su propia divinidad, okuaararávyma

[y en virtud de su sabiduría creadora ayvu rapytarã i oikuaa ojeupe.

[concibió el origen del lenguaje humano.

Oyvárapy mba'ekuaágui,

[de la sabiduría contenida en su propia divinidad, okuaararányma,

[y en virtud de su sabiduría creadora, ayvu rapyta oguerojera

[creó nuestro Padre el fundamento del lenguaje humano ogueroyvára Ñande Ru. [...]

[e hizo que formara parte de su propia divinidad [...].

\section{LA TRADICIÓN ORAL GUARANÍ PARAGUAYA: UN LARGO DESTIE- RRO DE LA REPÚBLICA DE LAS LETRAS}

La tradición popular con la que entronca la actual literatura paraguaya en guaraní es también marcadamente oral, aun cuando se haya alejado o hasta se haya distanciado de su remoto substrato indígena. La imaginación y la sabiduría colectivas se han volcado durante siglos sobre todo en los siguientes géneros (cf. González Torres 1992):

- narrativos: el káso y el mombe'u gua'u (cuento 'ficticio'): breves historias verdaderas o inventadas, a menudo satírico-humorísticas y protagonizadas por personajes y figuras típicas como el mono ka'i, el pychãi (pobre pícaro que tiene los pies llenos de niguas) o Perurima, lejano descendiente de Pedro. de Urdemalas, así como las leyendas sobre seres fabulosos que en parte provienen de la mitología indígena, como el duende del bosque jasy jatere ${ }^{1}$;

- líricos: las coplas de las antiguas canciones populares (a veces más narrativas que poéticas), las letras de canciones (purabéi) cantadas al ritmo de la polca paraguaya o la nostálgica guarania; los rítmicos versos de las adivinanzas populares e infantiles; los cantos relacionados con la Navidad y otras festividades religiosas;

- dramáticos: el teatro popular e improvisado en el que, según la categoría social de los personajes, se puede mezclar, de forma espontánea y natural el discurso en guaraní con el castellano;

- pragmáticos: el rico caudal de los ñe'ẽnga, proverbios que en un tono serio-jocoso reflejan la sabiduría del campesino paraguayo, p. ej.: Mboriabu memby reikuaa haguã, ijyva puku ba iñe'êkuaa mantearã («para que conozcas al hijo de la mujer pobre: siempre tiene los brazos largos [de tanto trabajar] y sabe hablar bien») (Aguilera 1996, 97).

Una consecuencia de la diglosia que durante siglos marginó al guaraní y sus hablantes fue que esta cultura sólo en muy contadas excepciones fuera considerada digna de la escritura: el idioma de las letras, por principio, tenía que ser el castellano. Apenas en determinadas constelaciones históricas - especialmente en los períodos de guerra, marcados por su extremo nacionalismo y por la necesidad de construirse una identidad diferenciadora frente a las naciones vecinas - se estimuló la actividad literaria en el idioma nativo. En muchas ocasiones, sin
1 traducción interlinear se encuentra en Lustig, 1995. Sobre el folklore «literario» del Paraguay véase Cardozo Ocampo 1991 y González Torres 1992. 


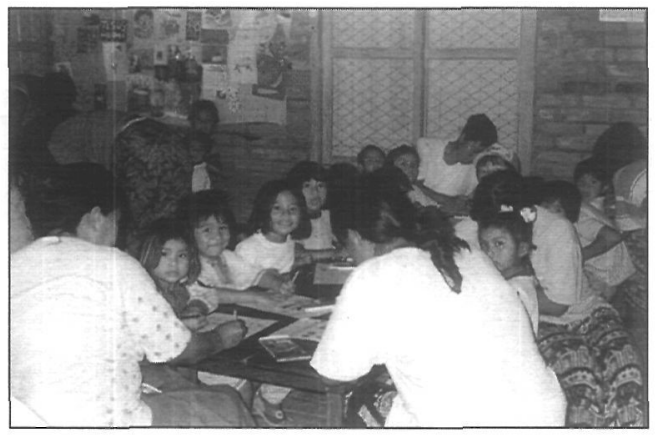

Niños indígenas en la escuela. (Foto: Mar Langa). embargo, no llegó a superarse el desprecio por la auténtica cultura del pueblo y se recurrió a modelos copiados de los «centros» culturales y a un lenguaje artificial y elaborado. Así no han faltado ni los versos encomiásticos que ensalzan los progresos de la civilización técnica en forma de hexámetros ni los inten2 En el ámbito de la política lingüistica - tal como exitosamente se aplica en Cataluña- la normalización de una lengua inicialmente marginada significa que ésta vuelva a emplearse «normalmente» en todos los ámbitos y todas las formas de comunicación.

3

El empleo «normalizado» en la enseñanza y el uso en los libros de texto puede llevar a la aceptación de un término como ñe'ẽporãhaipyre, que también corresponde al título del hasta ahora único manual didáctico de literatura paraguaya en guaraní (Acosta Alcaraz 1995). Sin embargo existe la propuesta de otro término: ñe'ẽporãporavopyre que hace referencia más bien a "las bellas palabras seleccionadas» y abarca tanto lo escrito como lo oral. tos de traducir el Quijote al guaraní.

Hasta se podría formular la hipótesis de una «diglosia de segundo grado» que escinde en dos el dominio de la cultura paraguaya de expresión guaraní y que más que nunca constituye un problema para su «normalización» ${ }^{2}$ en el ámbito literario. Es decir, los «profesionales» de la cultura, o por lo menos un poderoso sector entre ellos hablan y sobre todo escriben y prescriben un guaraní que no es el del pueblo, aferrándose a una absurda «pureza» de la lengua. Según los defensores del guaraniete (el «verdadero» guaraní), al escribir en la lengua autóctona hay que reducir al mínimo el uso de hispanismos - requisito muy difícil de cumplir si se considera que, debido a las restricciones impuestas al uso del idioma, el léxico cubre principalmente las necesidades de una sociedad campesina de principios del siglo XIX. Es verdad que la estructura polisintética del guaraní facilita la formación de neologismos: así se ha acuñado, p. ej., el término ñe'ẽporãbaipyre para «literatura» ${ }^{3}$. Pero el que no está iniciado en la terminología especializada entiende a lo sumo «escritura de hermosas palabras» y para él la lectura de un texto plagado de tales creaciones puede convertirse en un frustrante juego de adivinanzas. No se pueden cerrar los ojos ante el hecho de que la realidad lingüística del Paraguay está caracterizada por la profunda compenetración léxica y sintáctica del guaraní con el español paraguayo. El discurso jopara, cuya estructura es esencialmente guaraní pero que integra un alto porcentaje de vocabulario español (cf. Lustig 1996), sale - muy a pesar de algunos maestros - de la boca de todos.

\section{PRIMER CICLO: PATRIOTISMO Y FOLKLORIZACIÓN}

Si ahora queremos desenterrar los gérmenes de lo que con derecho se puede llamar «li- teratura en guaraní» tenemos que volver a la segunda mitad del siglo XIX. Su "padrino» es en cierto sentido el Cacique Lambaré, la primera revista exclusivamente en guaraní que apareció como órgano de propaganda en 1867, durante la Guerra de la Triple Alianza contra el Brasil, la Argentina y el Uruguay. En sus páginas (y en las de otras revistas de guerra de la misma época) encontramos artículos programáticos que reivindican la creación de una literatura nacional y patriótica en la lengua nativa (Lustig 2002). Numerosas contribuciones, que habría que adscribir a los géneros tradicionalmente orales de la canción y el káso, ilustran la posibilidad de «escribir bien» en guaraní, incluso según reglas ortográficas relativamente coherentes, concebidas especialmente para las revistas. Las muestras de esta nueva literatura adolecen ciertamente de una alta carga ideológica y un tono sumamente panfletario.

Sin embargo, esta instrumentalización ideológica será la característica predominante de la literatura en guaraní prácticamente hasta mediados del siglo XX. Como paradigmático representante de la "generación nacionalista indigenista» (cf. Bareiro Saguier 1978) se podría mencionar al «poeta de la raza» Narciso R. Colmán. Entre otras obras más bien de inspiración folklórica publicó, en 1929, bajo el seudónimo de Rosicrán, Nande Ypykuéra, un intento de recrear románticamente el mito de los orígenes guaraní-paraguayos (cf. Melià 1992, 208). Ya el subtítulo de su obra es programático: Poema etnogenético y mitológico. Protobistoria de la Raza guaraní, seguida de un estudio etimológico de los mitos, nombres $y$ voces empleadas.

La literatura «épica» en guaraní - en el contexto paraguayo lo épico tiene una conexión estrecha con lo marcial y lo patriótico - encuentra su culminación en las creaciones sumamente exitosas del «Tirteo verdeolivo» Emiliano R. Fernández. Sus canciones de la Guerra del Chaco (1936-39), que en su momento levantaron el ánimo de los combatientes, circulan hasta hoy en numerosas antologías, además de los discos $y$ casetes que inmortalizan musicalmente al vate popular (Lustig 1997; Romero 1996).

La literatura de esta primera fase se articula bajo el signo de lo folklórico y lo patriótico, y muy a menudo se pone deliberadamente al servicio del régimen. Como última muestra de esta vena citamos una estrofa de la 
canción Ta ipoty nande reta (Taipoty ñane retã / «Que florezca nuestra nación») que el folklorista, poeta y compositor Mauricio Cardozo Ocampo dedica, en una recopilación de sus obras, al dictador Alfredo Stroessner (Cardozo Ocampo 1980, 119)4:

Nde che retä Paraguái

A ti mi patria paraguaya,

ndévena ta purajhei

[a ti quiero cantar,

jhi'äitégui amombe'ú

[porque me da gusto voy a contar

mba'eichaitépa ne porä.

[cuán hermosa eres.

Ndaipórico ndeicha guá

[No hay otra como tú

re mimbi re jhesapé,

[que brillas y alumbras,

jhetaité mba'é porä

[tantas cosas lindas

re recóva nde pypé. [...]

[que tienes dentro de ti. [...]

Peina General Stroessner

[He aquí el General Stroessner

oisambyjhy ñande retä

[que conduce nuestra patria,

ichupé ñaipytyvóne

[a él le vamos a ayudar,

yaipotáramo opu'ä.

[si queremos que crezca (la nación).

\section{CAMBIO DE CLIMA Y NUEVA IN- FRAESTRUCTURA}

A partir de la década de los 80 el panorama de las letras en guaraní experimenta una reestructuración profunda. Una de las razones reside, seguramente, en que la pobreza, la injusticia y la opresión sufridas por una gran parte del pueblo paraguayo bajo el régimen de Stroessner, cada vez más insoportable, buscan y encuentran su expresión literaria genuina en la lengua de los pobres, que es el guaraní. $\mathrm{Pa}$ rece sintomático al respecto un breve texto literario en guaraní que Roa Bastos emplea como leitmotiv del Capítulo IV de Hijo de hombres: el canto del mensú, explotado trabajador de los yerbales.

Anive angána, che compañero,

[iAy, mi compañero! ¡No sigas

ore korazõ reikytĩ asy ${ }^{6}$

[rompiendo cruelmente nuestro corazón!
Para esa generación de escritores e intelectuales, recuperar la lengua empobrecida y marginada es en sí un acto de protesta y compromiso y no implica necesariamente una temática abiertamente política (que además había que evitar en el contexto de la

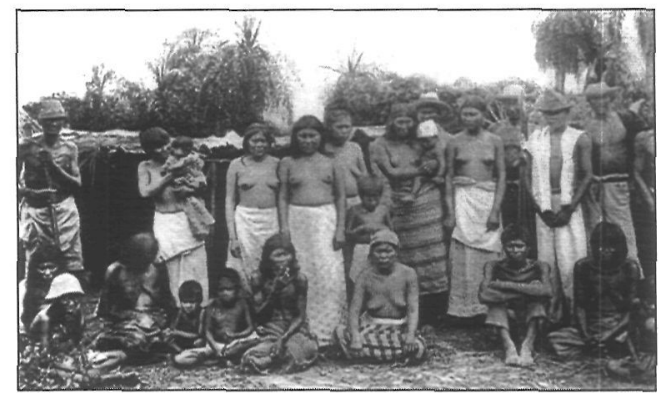

Encomiendas indígenas. (Foto: archivo de Jorge Rubbiani). persecución y la censura).

Entre las revistas que surgen en ese período, puestas al servicio del fomento y la divulgación de la literatura, destaca la revista bilingüe de cultura Ñemitÿ («siembra»), que acoge contribuciones literarias en guaraní de todos los géneros, además de artículos de crítica literaria y de lingüística. Desde 1977 se han publicado más de cuarenta números.

Lo que después de la caída de la dictadura favorece sobremanera la eclosión de la literatura en guaraní es - más que la mera oficialización del idioma en la Constitución de 1992- la Reforma Educativa, que vuelve obligatoria la enseñanza de la lengua y la literatura guaraní en la Educación Escolar Básica e implementa por primera vez, desde el tiempo de los jesuitas, las prácticas de lectoescritura ${ }^{7}$. En los nuevos libros de texto ${ }^{8}$ se valoran y estudian obras y autores e incluso se estimula la creatividad literaria de los alumnos.

Esta intromisión estatal ha estimulado el mercado del libro en guaraní. Como deducimos - entre otras fuentes - del catálogo de Guarani Raity, la hasta ahora única librería especializada para libros en guaraní, desde 1981 han aparecido más de 90 títulos en los géneros poesía, narrativa, teatro y antologías. El gráfico demuestra que, una vez sueltas «las ataduras de la lengua» con la democratización de 1989, la producción editorial conoce un aumento considerable, especialmente a partir la implementación definitiva de la educación bilingüe en 1994, y que el género literario más cultivado es la poesía?.
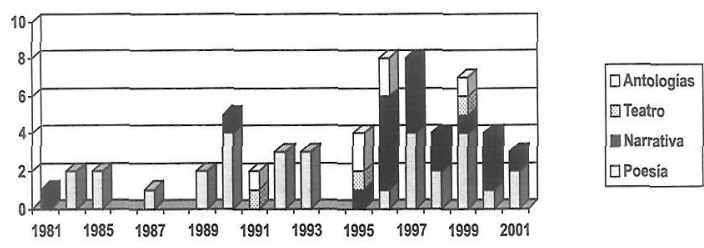

$\begin{array}{llllllllll}1981 & 1985 & 1987 & 1989 & 1991 & 1993 & 1995 & 1997 & 1999 & 2001\end{array}$

Literatura paraguaya

en guaraní

WOLF LUSTIG 
10

Accesible por hitp://www.guarani.de

11

hitp://www.cervantesvirtual.com /portal/paraguay/ - Aquí se puede consultar Karai Rrei oha'ãramo guare iuka'ẽ kañy («De cuando Karai Rey jugó a las escondidas"), de Juan Bautista Rivarola Matto, en versión bilingüe.

\section{2}

Una escena en versión bilingüe es accesible en http://www.unimainz.de/ /ustig/guarani/sandia.htm.

13

El texto de Rubén Rolandi conserva ciertas marcas ritualizadas del discurso narrativo oral, p. ej. hace terminar cada uno de sus kásos con la fórmula ha upépe opa ("y ahí se acaba»).

14

Cf. Lustig 1996, donde se comentan algunos aspectos lingüistico-literarios de este texto. Una nota biográfica sobre la autora, así como un extracto de Ramona Quebranto, está disponible en el mencionado sitio de la Biblioteca Virtual Cervantes (hitp: // cervantesvirtual.com

15

Sobre la lírica moderna en guaraní compárese Lustig 1997 en la antología de Méndez-Faith, la cual ofrece una visión de conjunto de la lírica en guarani desde finales del siglo XIX.
La expansión de Internet como medio de publicación y divulgación constituye otro factor que influye positivamente en la revitalización de muchas lenguas y literaturas minorizadas. Citemos como ejemplo el sitio Guarani Nanduti Rogue ${ }^{10}$, que desde 1995 se dedica a la cultura paraguaya de expresión guaraní y ofrece una plataforma para la publicación de textos clásicos y actuales. Recientemente la Biblioteca Virtual Miguel de Cervantes inauguró un portal de literatura paraguaya en el cual aparecen textos íntegros de narrativa en guaraní11.

\section{SEGUNDO CICLO: LA EMANCIPA- CIÓN DE LA PALABRA EN GUA- RANÍ}

No existe todavía ninguna historia de la literatura en guaraní, pero se cuenta con algunos trabajos que dan una idea bastante completa del quehacer literario guaraní-paraguayo (Pla 1973, Melià 1992, Acosta 1995, Méndez Faith 1997). Por lo tanto nos limitaremos a mencionar para cada género dos o tres obras $\mathrm{y}$ autores que consideramos representativos de las tendencias actuales.

Empezamos con el teatro que se presenta como un género-puente entre la vieja y la nueva literatura en guaraní porque desde siempre ha mantenido el contacto con la auténtica realidad lingüística y social del pueblo, y no ha sido alterado por el pasaje a la escritura, que sigue siendo el mero soporte de lo oral. En no pocas ocasiones las piezas llegaron a la imprenta con unos 50 años de retraso, como en el caso de Sandía yoyguy ( $S$ Sandía enterrada», 1933/1981) ${ }^{12}$ y Karu pokã ( Los mal comidos», 1941/1980) de Julio Correa (18901954), uno de los pioneros de la nueva literatura en guaraní, tanto en el teatro como en la poesía (cf. Romero 1995). La Guerra del Chaco, ambiente de las piezas de Correa, persiste como tema de obras dramáticas más recientes como Anivéna karaikuéra ("iBasta, señores!», 1995) de Demetrio Ortiz. Como el teatro popular se enriquece considerablemente con la realización escénica e integra siempre una gran dosis de improvisación, pertenece más a lo oral que a lo escrito. A pesar de ello tiene una función cada vez más importante para la literatura en guaraní, ya que muchos textos originariamente narrativos llegaron al gran público por vía de una adaptación teatral, así como muchos textos líricos se popularizaron a través de canciones.

Posteriormente llevado al palco fue también Kalaito Pombero (1981) de Tadeo Zarratea (1947). Esta obra, que temática y estructuralmente se insiere en la tradición picaresca-costumbrista, destaca por ser la primera novela escrita originariamente en guaraní. Una práctica que obedece a la falta de costumbre de leer en guaraní es que los textos - Kalaíto Pombero así como la mayoría de los volúmenes de poesía - se editan en versión bilingüe. Paralelamente a lo que podemos llamar la «narrativa culta» se sigue cultivando el káso ñemombe’u ("el contar 'casos»), que en sus versiones escritas, algunas veces destinadas primordialmente al uso didáctico, no necesariamente pierden su encanto. Como ejemplo de este género se puede mencionar la colección Kásos. Abendu abai (1989) de Rubén Rolandi, donde se dan cita los fantásticos seres y las creencias que pueblan la imaginación campesina, como Luisõ, Pombéro, karai Rréi y la esperanza de encontrar pláta yoyguy, los legendarios tesoros enterrados durante la Guerra Grande ${ }^{13}$.

En la mayoría de los textos literarios en guaraní se nota cierto afán de «defensa e ilustración de la lengua». Se evita el contagio del jopara, «habla idiota de la senilidad colectiva, el ñe'ẽ tavy del débil mental», según el juicio de Roa Bastos (1993, 280). Precisamente por ello merece mención Margot Ayala de Michelagnoli (1935) con su novela corta (llevada exitosamente al teatro por Mario Halley Mora) Ramona Quebranto (1989). Cuenta - o más bien representa en diálogos sumamente naturales, en la típica mezcla caótica de guaraní y español paraguayo - los «quebrantos» de una joven mujer de origen campesino que intenta sobrevivir de alguna forma en una barriada de Asunción ${ }^{14}$.

Es en el campo de la lírica donde son más notables las innovaciones que caracterizan la escritura en guaraní del último cuarto del siglo $\mathrm{XX}^{15}$. La poesía se emancipa y se «descolonializa»: supera la retórica heredada del romanticismo y abandona los metros clásicos de la tradición hispánica o grecolatina que forzaban el verbo guaraní en un lecho de Procusto. No es exagerado decir que la lírica moderna en guaraní libera la lengua de su cárcel, rompiendo sus ataduras, como lo proclaman lite- 
ralmente los versos de Félix de Guarania (1924) en el poemario Tojery kuaraby ("Que vuelva el sol») de 1989:

$\begin{array}{ll}\begin{array}{l}\text { Añandu } \\ \text { che pirĩ }\end{array} & \text { Siento } \\ \text { hoy'sã } & \text { escalofríos } \\ \text { che aguije. } & \text { se enfría } \\ \text { Kirirĩ̃ } & \text { mi alma. } \\ \text { kyhyje, } & \text { Silencio, } \\ \text { tekove } & \text { temor, } \\ \text { oñapytĩ. } & \text { vida } \\ \text { ¡Mba'épo } & \text { atada. } \\ \text { ojehu } & \text { ¡Qué } \\ \text { che retã } & \text { pasa! } \\ \text { i'ñe'ẽngu! } & \text { ¡Mi país } \\ & \text { está mudo! } \\ \text { ¡Anive } & \text { Suelten } \\ \text { peipykua ñe’ẽ! } & \text { las ataduras de la lengua! } \\ \text { Peheja } & \text { Dejen que } \\ \text { toveve, } & \text { vuele, } \\ \text { tohasa, } & \text { pase, } \\ \text { toheka } & \text { busque } \\ \text { tape, } & \text { camino, } \\ \text { tojoka } & \text { rompa } \\ \text { ko'ẽ... } & \text { el amanecer... }\end{array}$

Estéticamente, la originalidad de la nueva poesía consiste en que pone en evidencia las insólitas calidades rítmicas y musicales del guaraní. Ramón R. Silva (1954) da un paso más en esta dirección. Su especialidad es el estilo tangara, que ha dado el título a un poemario publicado en 1985 . Se inspira en una danza de los Mbya, en la cual la magia del ritmo acercaba al hombre de las fuerzas primigenias. Pero no se trata de una incursión anacrónica en lo indigenista (cf. Lewis 1991) o de una indagación etnográfica. En el poema Paraguái ñe $e^{16}$, por ejemplo, la fuerza «mágica» de la palabra conmoverá a cualquier paraguayo de habla guaraní, y no dejará de fascinar a los lectores o, mejor, «oyentes» que no participen de aquel trasfondo cultural.

Como tercera y última figura en el concierto de nuevas voces en guaraní mencionaremos a Susy Delgado (1942), que con $\mathrm{Ta}$ taypype («Junto al fuego», 1992), llegó a finalista en el concurso del Premio Casa de las Américas de 1991. El tataypy, lugar donde se enciende y guarda el fuego en la casa campesina, se constituye en símbolo del mundo guaraní (Delgado 1992, 48ss.):

Toupáke

QQue vengan todos

chaguélo ñeẽme

[los que han resucitado

oikove jeýva.

[en la voz del abuelo.

Toguerúke hikuái

[Que traigan

hembiasakue,

[sus historias

tomyasãi tataypýpe,

[y las desparramen junto al fuego

tañanemondýi,

[para que nos asusten,

tañanemombáy,

[nos desperecen

toñembosarái ñanendive.

[y jueguen con nosotros.

Toúke hikuái,

[Que vengan,

toguapy, topyta,

[se sienten y se queden

ha mitã toipe'áke hesa,

[y que abran sus ojos los niños,

taipirĩ,

[tengan escalofrios

topuka.

[y rían.

Taiko'êke mitã akã ruguápe,

IY que amanezca en el fondo de su memoria,

ñe'ẽ.

[la palabra.

En la constitución formal del texto son evidentes las aliteraciones y los paralelismos que realzan la sonoridad y el ritmo de la palabra. A nivel del significado se observa cómo el tataypy ya no es sólo el lugar del fuego sino también el asentamiento de la palabra - el ayou rapyta, que fue el punto de partida de nuestro recorrido por el universo del guaraníne'ê. En torno de él se realizan la comunicación y el intercambio entre las generaciones en forma de voces y relatos. La dimensión pragmática tiene el doble cariz de invitación y plegaria: un convite dirigido a la gran familia a reunirse alrededor del fuego y escuchar la palabra, y al mismo tiempo una oración para que la palabra en guaraní no pierda su virtud salvadora entre las futuras generaciones.

Ha upépe opa.
16

Silva 1985. El texto completo con traducción se puede consultar en hitp://mww.uni-mainz.de/ /ustig/guarani/paranee.hm. 


\section{BIBLIOGRAFÍA}

ACOSTA ALCARAZ, Feliciano, Ñe'êporãhaipyre. Asunción, 1995.

AGUILERA, Domingo Adolfo, Ñe'ẽnga. Dichos populares paraguayos. Asunción, CEPAG, 1996.

BAREIRO SAGUIER, Rubén, «La generación nacionalista indigenista del Paraguay y la cultura guarani», en Actes du XLIIe Congrès International des Américanistes, Paris, 1976, págs. 549-555.

CADOGAN, León, Ayvu rapyta. Textos míticos de los Mbyá-Guarani del Guairá. Asunción, CEADUC-CEPAG, 1992.

CARDOZO OCAMPO, Mauricio, Mis bodas de oro con el Folklore paraguayo. Memorias de un Pychãi. Asunción, Ed. Cuadernos Republicanos, 1980 (11972).

CARDOZO OCAMPO, Mauricio, Mundo folklórico Paraguayo. 3 Vols. Asunción, Ed. Cuadernos Republicanos, 1992.

DELGADO, Susy, Tataypype - Junto al fuego. Asunción, Arandurã, [1992].

GONZÁlEZ TORRES, Dionisio M., Folklore del Paraguay. Asunción, 1992.

GUARANIA, Félix de, Tojevy kuaraby. Asunción, 1989.

- Lengua y literatura castellano / guaraní [3 vols. $7^{\circ}-9^{\circ}$ grado], Asunción, Santillana/Alianza, 1999-2001.

LEWIS, Tracy K., «Indígena e Indigenista en la literatura guaranítica paraguaya. ¿Un fracaso de etiquetas?», en PREUSS, Mary H. (ed.). Past, Present and Future. Selected papers on Latin American Literatures, Culver City, Labyrinthos, 1991, págs. 123-28.

LÓPEZ AUSTIN, Alfredo, La literatura de los Guaraníes. Introducción, selección y notas por León Cadogan. México, Mortiz, 1965.

LUSTIG, Wolf, «Ein Portrait des 'guaraní paraguayo», Hispanorama, 69 (1995), págs. 19-27.

LUSTIG, Wolf, «Mba'éichapa oiko la guarani», Papia, 4:2 (1996), págs. 19-43.

LUSTIG, Wolf, «Ñande reko y modernidad. Hacia una nueva poesía en guaraní», en MÉNDEZ FAITH 1997, págs. 21-48.

LUSTIG, Wolf, "Chácore purahéi-canciones de guerra. Literatura popular en guaraní e identidad nacional en el Paraguay", en POT'T'HAST 1999, pp. 363-379.

Literatura paraguaya en guaraní WOLF LUSTIG
LUSTIG, Wolf, «Die Auferstehung des Cacique Lambaré. Zur Konstruktion der gua- rani-paraguayischen Identität während der 'Guerra de la Triple Alianza'”, en LANG, Sabine / BLASER, Jutta / LUSTIG, Wolf (eds.). 'Miradas entrecruzadas' - Diskurse interkultureller Erfabrung und deren literarische Inszenierung. Beiträge eines bispanoamerikanistischen Forschungskolloquiums zu Ebren von Dieter Janik. Frankfurt/M., Vervuert, 2002, págs. 159-185. MELIÀ, Bartomeu, La lengua guarani del Paraguay. Historia, sociedad y literatura. Madrid, MAPFRE, 1992.

MELIÀ, Bartomeu, «Reducción literaria y alfabetización», en MELIÀ, Bartomeu. Elogio de la lengua guarani. Contextos para una educación bilingüe en el Paraguay, Asunción: CEPAG, 1995, págs. 89-98.

MÉNDEZ FAITH, Teresa, Poesía paraguaya de ayer y de hoy. Tomo II, Guaraní- español. Asunción: Intercontinèntal, 1997.

PLA, Josefina, «La literatura paraguaya en una situación de bilingüismo», en PLA, Josefina. Obras completas. Ed. de M. A. Fernández, Asunción: RP Ediciones, 1992, III, págs. 7-35.

POTTHAST, Barbara / KOHUT, Karl / KOHLHEPP, Gerd (eds.), El espacio interior de América del Sur. geografía, bistoria, política, cultura, Frankfurt/M, Vervuert, 1999.

ROA BASTOS, Augusto, «La narrativa paraguaya en el contexto de la narrativa hispanoamericana actual», en SCHRADER, Ludwig (ed.). Augusto Roa Bastos. Actas del Coloquio Franco-Alemán (Düsseldorf, 1-3 de junio de 1982), editadas por Ludwig Schrader. Tübingen, Niemeyer, 1984, págs. 1-11.

ROA BASTOS, Augusto, Hijo de hombre. Buenos Aires, Sudamericana (2a . edición), 1990.

ROA BASTOS, Augusto, «Del buen uso de los mitos», en TOVAR, Paco. Augusto Roa Bastos. Antología narrativa y poética, Barcelona, Anthropos, 1991, págs. 78-80.

ROA BASTOS, Augusto, El Fiscal. Buenos Aires, Sudamericana, 1993.

ROMERO, Roberto A., Protagonismo bistórico del idioma Guarani. Asunción, 1992.

ROMERO, Roberto A., Julio Correa. Escritor social. Asunción, Universidad Autónoma, 1995.

ROMERO, Roberto A., Emiliano R. Fernández. Mito y realidad. Asunción, 1996. 
SÁNCHEZ, Luis Alberto, Proceso y contenido de la novela hispanoamericana. Madrid, Gredos, 1968.

SILVA, Ramón R., Tangara Tangara, Asunción, Eds. Taller, 1985.
STECKBAUER, Sonja, «La situación del guaraní en el Paraguay actual», en POTTHAST 1999, págs. 381-399. 


\section{Reni Marchevska}

Profesora Titular de Literatura Hispanoamericana de la Universidad «San Cirilo y Metodio», de Veliko Tarnovo (Bulgaria). Ha publicado diversos artículos sobre autores hispanoamericanos. En la actualidad ha centrado su interés en la última narrativa hispanoamerica y más concretamente en el género del cuento. Tiene compilados dos volúmenes antológicos de cuentos hispanoamericanos: Espejos Cóncavos (Sofia, Heizel, 2000) y El cuento hispanoamericano actual (Sofia, 2000), antología muy destacable consumada en el Grupo Latinoamericano de Sofia.

\title{
UNA MIRADA HACIA «LOS NUDOS DEL SILENCIO»DE RENÉE FERRER
}

\author{
RENI MARCHEVSKA
}

En el marco de la literatura hispanoamericana escrita por mujeres, Los nudos del silencio comparte algunas de las características temáticas de las obras que cuestionan los papeles tradicionales en la sociedad patriarcal y la marginación social, económica y cultural de la mujer. Desde perspectivas distintas, la deconstrucción de los valores hegemónicos y la relativización de las jerarquías indiscutibles han sido el blanco de narradoras como la colombiana Fanny Buitrago, la argentina Reina Roffe, las uruguayas Cristina Peri Rossi y Tereza Porzecanski, las puertorriqueñas Ana Lydia Vega y Rosario Ferré, la chilena Diamela Eltit o la mexicana Angeles Mastretta, por mencionar algunas.

Al firme propósito de romper con el aislamiento y el vasallaje de la mujer se suman también los esfuerzos de la escritora paraguaya Renée Ferrer en su primera incursión en la novela. El enfoque feminista, sin embargo, no premia sólo y exclusivamente la explotación de la mujer por el varón. Esta temática se inscribe en un contexto mayor - el ejercicio del poder en los estados de gobierno totalitario-. A la par con una sutil penetración en las almas de los personajes, Ferrer combate los pilares que sustentan el estereotipo de la mujer como esposa y madre sumisa y abnegada y el mito del macho prepotente, cabeza de familia y por tanto única autoridad para sus miembros, pero condena también la agresión y el poder en todas sus manifestaciones. La historia del $\mathrm{Pa}$ raguay esta marcada por episodios horripilantes, violencia y sangre. El profundo marasmo en que la última dictadura sumió al país dejó profundas heridas en la conciencia nacional. El ambiente de asfixia y agobio subyace en to- dos los niveles de la obra. En este sentido, se desprende de Los nudos del silencio una honda preocupación por el respeto de las libertades y la dignidad humanas y un agudo juicio sobre el ejercicio deliberado del poder en todas sus dimensiones: política, social, económica y cultural.

La aplastante realidad paraguaya trasciende en la novela de Ferrer los limites de un país concreto para abarcar - a través de la alusión a los bombardeos contra Vietnam - a todos los países que han padecido o siguen padeciendo el peso de la monstruosa pirámide de la opresión. Cruce de ideas progresistas, Los nudos del silencio adquiere universalidad también por la excepcional prosa lírica, independiente de convencionalismos escriturales y moldes genéricos, dotada de una mayor atención al lenguaje y un trabajo más cuidadoso sobre las estructuras y los recursos narrativos que va aboliendo la censura y la univocidad de sentido a favor de un compromiso abierto con la problemática tratada y una perdurabilidad y efectividad política, social y estética. El argumento, resumido en pocas palabras, se centra en las relaciones interpersonales de un matrimonio de la burguesía paraguaya - Manuel y Malena - que se va de viaje a París. De gustos distintos - a ella le gusta la música clásica, a él los espectáculos eróticos-, Manuel no quiere oír las súplicas y las protestas de su esposa, criada con la rígida moral de la sociedad patriarcal, y en vez de acompañarla al concierto que ella había elegido, la lleva, contra su voluntad, a un burdel de ínfima categoría donde «se ofrecen emociones reservadas para unas pocas personas». Hundida en la butaca, casi invisible, entre «hombres solos masticando 
una lujuria que no intentaban esconder», $\mathrm{Ma}$ lena mira el escenario donde bailan dos vietnamitas - Luis y Mei Li-. Las expectativas de Manuel de disfrutar de un porno-show que afirme la superioridad del hombre se ven frustradas por las escenas lésbicas que protagonizan las dos mujeres. Humillado más que decepcionado, Manuel insiste en abandonar el lugar, pero Malena se niega a obedecer su orden, intrigada por las relaciones desconocidas por ella que el espectáculo ofrece.

A partir de este incidente en la vida conyugal de Malena y Manuel, Ferrer va construyendo una obra de compleja arquitectura y múltiples resonancias. Sobre el espacio blanco de las páginas se va imprimiendo el espacio cerrado de la represión política, la opresión familiar y la soledad de la mujer sometida: enorme «nudo» de impenetrables silencios que oprime la garganta.

Mas allá de la experimentación lingüística y formal, Ferrer ahonda en el devenir humano y la temática de la libertad individual, la ruptura del aislamiento - la comunicación, el amor, la solidaridad - y la búsqueda de la trascendencia - social, metafísica o humana-. En su relación con Manuel, Malena ha adoptado siempre por la actitud pasiva. Como toda mujer casada, está sujeta a su marido, quien la humilla y protege alternativamente, convirtiéndola en un animalito de adorno que se trata con desdeñosa benevolencia. El abuso del poder, práctica cotidiana para el torturador que presta sus servicios al régimen, se extiende también a sus relaciones conyugales. $\mathrm{Ne}$ gándole una realidad propia a Malena, Manuel promulga sus leyes, defiende su libertad personal, su supremacía como individuo y su propiedad, parte de la cual es su esposa. El silencio es la máscara que pone para ocultar los crímenes en que participa y su verdadera naturaleza, homologada por Malena con la de las bestias. El espacio de la dictadura - perfectamente identificable, delimitado, con sus lugares de tortura y sufrimiento-, y el del patriarcado, a cuyos cánones se ha de ajustar toda pareja que se quiere respetable, resultan relevantes para la organización del contenido y el mensaje de la obra. Descrita con un lenguaje violento - «el agua grita turbia en la pileta donde flotan los sollozos, los pedidos de clemencia, las blasfemias, finalmente, el silencio» (pág. 140) - la imagen de la dictadura y sus métodos, como una de las caras del poder,

está personificada por Manuel, copia en miniatura del dictador latinoamericano. La impunidad alimenta y reafirma su arrogancia, su orgullo de pertenecer a la única especie dotada de inteligencia suficiente para participar en el gobierno del país y tirar las riendas de los asuntos familiares. A su actitud cínica la autora contrapone el estereotipo de la mujer abnegada. Fingir, siempre en silencio, «acuclillada tras los barrotes del silencio»: imagen que define no sólo a Malena, sino a todas las mujeres cuya existencia esta marcada por las normas morales de la sociedad patriarcal y la opresión del varón. Tragarse todos los sorbos amargos, sin la menor resistencia. Renunciar has-

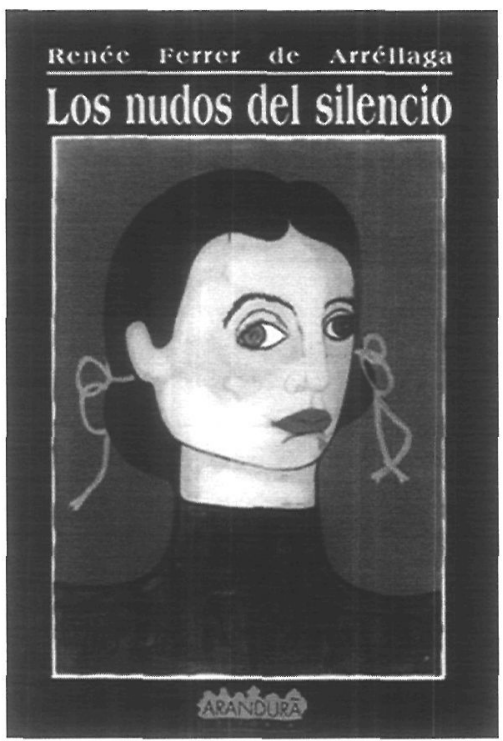

Los nudos del silencio. Portada. (llustración de María Cristina Aragón). ta a los sueños más íntimos con tal de hacer feliz al hombre que se ama y respeta. En el pequeño burdel parisino, Malena se enfrenta con una relación chocante, insólita para su educación. El sexo - uno de los temas que traduce la ambigüedad-, permite la contraposición de los protagonistas y la oposición de maneras distintas de entender las relaciones amorosas. Una, la del hombre, movido únicamente por las bajas pasiones; y la otra, que busca su dimensión humana. Un abismo separa a Manuel y Malena que comparten el mismo lecho, mas por motivos distintos. Su concepto de la relación sexual queda perfectamente delineado por los pensamientos que provoca en ambos el espectáculo lésbico: «¿Cómo será en la cama semejante especimen, se pregunta intrigado Manuel, que no puede parar el empuje de su torrentosa imaginación?»/ «Qué destino el de los hombres, tan semejante al de las bestias, cuando el orgasmo se vuelve mero detalle en la horizontal selva de la entrega! (...) ¿Y los temblores del alma? ¿Y ese explorarse en el deseo como si estuviéramos desvistiendo una fruta madura?». Los recuerdos y las reflexiones de Malena, por una parte, y el punto de vista de Manuel, por otra, permiten a la autora participar en el discurso de los personajes e insertar una serie de observaciones sarcásticas acerca de la diferencia entre hombres y mujeres en lo referente su vida emocional y sus relaciones con el poder del varón. La homosexualidad femenina, que en la novela dista de lo obsceno y lo vulgar, opone la sensibilidad y los auténticos afectos a la bru- 


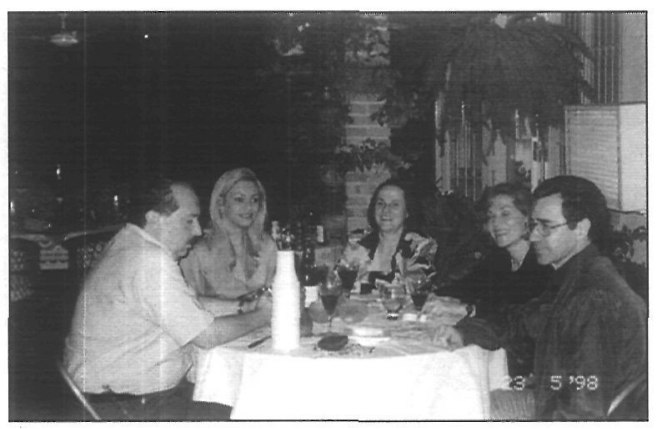

Helio Vera, Reneé Ferrer, Ma Elena Villagra y Guido Rodríguez Alcalá. (Foto: Mar Langa). talidad y a la violencia, latente en todos los niveles del texto, con implícitas remisiones a la realidad extralingüística. En la repulsa y el desdén con que Malena mira a la vietnamita, se introduce, paulatinamente, siguiendo las fugas del saxo, algo que desconcierta y remueve la conciencia, algo que va anulando los valores de una sociedad machista, autoritaria, falsa, puritana. Comunicación extraña la que en la noche establecen los ojos. Comunicación que no necesita de palabras para reconocer y transmitir la profunda soledad y el sufrimiento. A partir de este pacto secreto, donde el lenguaje verbal como vía de comunicación estorba, se produce en Malena una profunda transformación: la toma de conciencia - primer paso hacia la libertad individual-.

El viaje de la protagonista por algunas de las posibilidades sensoriales que las relaciones sexuales entre mujeres pueden despertar, podría ser también una respuesta al viejo debate: ¿tiene que estar la sexualidad de la mujer limitada siempre a la del hombre? Este interrogante que inevitablemente suscita la lectura de la novela, no aboga explícitamente por el lesbianismo, sino que sustenta y refuerza el cuestionamiento de la visión equivoca, parcial e inconsistente que en las sociedades patriarcales se tiene de la plenitud de una relación y el derecho a la libertad individual en la elección del propio destino.

El mero hecho de situar la historia en un burdel y la presencia de Mei Li como protagonista del show apunta a otra preocupación: la de la prostitución y sus causas. En París, símbolo del progreso y de las nuevas ideas, la mujer sigue siendo objeto de maltrato y abuso sexual. Los mismos hombres defensores de la virtud y de la honestidad femeninos, que simulan fidelidad y respeto por los sagrados códigos del matrimonio, infringen las normas en cuya redacción tuvieron parte y adaptaron a su conveniencia. La contemplación que se da en los relatos de segundo orden - que confieren mayor objetivismo y veracidad al relato principal- converge en la formación de un clima de delirio, de «niebla» y «bruma». El fluir de la conciencia de Mei Li corre atrave- sando los lugares mas recónditos de su vida. Se confunden las imágenes; el pasado y el presente son una sola imagen: la miseria. «Una niebla de arroz se levanta desde las escudillas llenas (...)", "Se confunde con el azul de las butacas: la niebla. (...)», «Canela y anís. Canela y anís. (...) Canela y anís me persiguen. Olores. Momentos. Delicias, que no se si existieron o son puro sueño. El hambre se derrama dentro de mí. (...) Y todos llevamos el hambre tatuada en los ojos». El papel que la vietnamita desempeña para la evolución de Malena y su toma de conciencia viene justificado precisamente por la amarga experiencia de mujer que ha crecido en miseria y miedo al terror y la agresión, dominada y explotada - en su país primero, en Francia después-; de un cuerpo sellado para siempre por las marcas de la injusticia y la brutalidad.

La sensación de distancia y ausencia que Mei Li experimenta bailando, se hace mas nítida conforme avanza el espectáculo: «No soy aquí, prisionera de esta complacencia ajena, frente al insano placer de bocas ávidas y ojos voraces, sino en aquel tiempo primigenio, cuando aún era germen, bosquejo, perspectiva, y mis pasos eran pequeños. Lejos de este cuerpo que se doblega a los retorcimientos del saxo. Antes de mi primer recuerdo». Refugiarse en la infancia, en la inocencia, para poder soportar el pesado bulto de injusticias y de explotación. Lo mismo Mei Li que Malena se alimentan del pasado: una para olvidar, la otra para salir de la inercia y encontrar el camino hacia la independencia y la felicidad. Las notas persistentes del saxo provocan y se retiran dejando que Malena se sacuda del letargo y se decida a abandonar a Manuel. El destronamiento de la palabra autorizada y autoritaria en beneficio de una interacción verdaderamente dialógica es logrado con distintos recursos estilísticos propios de la poesía que enfatizan el significado de las palabras y anuncian el clímax. El silencio - clave para las múltiples interpretaciones que permite el texto- oculta las huellas del crimen y ahoga los gritos de las víctimas; es presencia, inexistencia y ausencia; es mutuo acuerdo y resignación, pero es también resistencia y rebeldía.

La novela coloca a la mujer como protagonista no porque sea su discurso el que prevalece, sino porque se convierte en sujeto de la acción, y con su acción se transforma y transforma a los demás. La subversión de los 
papeles tradicionales que atribuyen el papel activo del hombre y el pasivo a la mujer sugiere una reinterpretación de la feminidad y lo femenino reconociendo y revalorizando lo intrínsecamente femenino y aquello que le ha sido atribuido por la sociedad. La concienciación de Malena es símbolo de la mujer que vence el dogmatismo del patriarcado, pero es también símbolo del triunfo de la democracia en Paraguay con la subsiguiente apertura de la sociedad paraguaya al exterior. El manojo de sogas que Malena desata al terminar el espectáculo, "corrigiendo la curva endurecida por los años» remite asimismo a ese emerger del silencio de una nueva hornada de escritoras paraguayas que nos entregan obras de indudable calidad artística; obras de trascendencia nacional, continental y universal.

\section{BIBLIOGRAFÍA Y REFERENCIAS}

ALVAR, MANUEL, "Los murmullos opacos de la noche, sobre «Los nudos del silencio» de Renée Ferrer, op. cit., pp. 239-242.

ECO, UMBERTO, Lector in fábula. La cooperazione interpretativa nei testi narrativi, Ed. Bompiani, Milán, 1979.

FALCÓN, LIDIA, Mujer y sociedad. Barcelona, Fontanella, 1984.

FERRER, RENÉE, La narrativa Paraguaya (L II), en «Marcha», Tercera época, año XII, nº 138, abril 1998, edición electrónica.
FERRER, RENÉE, Los nudos del silencio, Asunción, Arandurâ, 1992.

FOSTER, DAVID WILLIAM: «Introducción a Los nudos del silencio», op. cit., pp. 7-10.

GENET'TE, GÉRARD, Palimpsestos. La littéra-

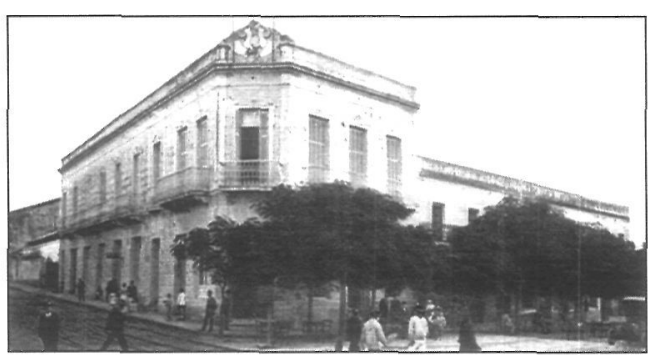

Asunción. (Foto: Archivo Jorge Rubbiani). ture au second degré, Edt. Du Seuil, Paris, 1982.

KANEV, VENKO, «El lenguaje poético» en Nociones teóricas de la estilística del texto literario, Sofia, 2000.

PACHECO, CARLOS, Narrativa de la dictadura y crítica literaria. Caracas, CELARG, 1987.

PARTYKA, BETSY: «Rompiendo las cadenas en Los nudos del silencio», op. cit., 211-215.

PEIRÓ, BARCO, JOSÉ VICENTE, edit.: «Portal de literatura paraguaya». En wrw.cervantesvirtual.com

PEIRÓ, JOSÉ VICENTE, «Erotismo y escritura antiautoritaria» en Los nudos del silencio. Estudios críticos, pp. 251-270. También en Daniel BALDERSTON edit.: Sexualidad y nación, Pittsburgh, Instituto Internacional de Literatura Iberoamericana (Biblioteca de América), 2000, pp. 199-212. RÍSQUEZ, F. Aproximación a la feminidad Caracas, Monte Ávila, 1991. 


\footnotetext{
Teresa Méndez-Faith

Esta investigadora paraguayo-estadounidense es profesora del St. Anselms College, universidad católica del noreste de los Estados Unidos. Doctorada en Filosofía y Letras por la Universidad de Michigan (Ann Arbor) en 1979, es una de las investigadoras que mayor empeño ha puesto en la regulación y el ordenamiento de datos y obras de la literatura paraguaya, cuyos frutos son su Breve diccionario de la literatura paraguaya, del cual prepara su tercera edición y es obra indispensable consulta y referencia para el acercamiento al tema, junto a sus antologías Narrativa paraguaya de ayer $y$ de hoy, Poesia paraguaya de ayer y de hoy, y Teatro paraguayo de ayer y de hoy. Su tesis doctoral se editó posteriormente con el título de Paraguay: novela y exilio. Entre otros numerosos trabajos sobre literatura de Hispanoamérica, fue la autora de las entradas de los autores paraguayos incluidos en el Diccionario de la Literatura Española e Hispanoamericana, dirigido por Ricardo Gullón, publicado en 1993.
}

1

Según Efraím Cardozo, en su Breve historia del Paraguay (Buenos Aires: Eudeba, 1965). Agrega él que de 1.300 .000 paraguayos vivos a principios de la guerra, sólo quedaron 300.000 al final, en su mayoría mujeres $y$ niños.

Núcleos temáticos recurrentes en la narrativa paraguaya del último cuarto de siglo

TERESA MÉNDEZ-FAIT'H

\title{
NÚCLEOS TEMÁTICOS RECURRENTES EN LA NARRATIVA PARAGUAYA DEL ÚlTIMO CUARTO DE SIGLO
}

\author{
TERESA MÉNDEZ-FAITH
}

De toda Latinoamérica, Paraguay es, probablemente, el país cuya producción literaria se ha visto más afectada por los aconteceres histórico-políticos de sus casi dos siglos de vida independiente. Es la única nación del continente que se inició como tal con una dictadura. En efecto, allí se instaló el régimen absolutista del primer gran dictador hispanoamericano, el Dr. José Gaspar Rodríguez de Francia, conocido como «El Supremo», quien aisló al Paraguay del resto del mundo y lo dominó como gobernante absoluto desde 1814 hasta su muerte en 1840. Le sucedió don Carlos Antonio López cuyo gobierno, también autoritario aunque constitucional, duró hasta 1862. Le siguió en el cargo su hijo, el Mariscal Francisco Solano López, una de las figuras más controversiales de la historia paraguaya. "Traidor a la patria» para unos y «héroe nacional máximo" para otros, durante su corto gobierno, Paraguay peleó y perdió la Guerra de la Triple Alianza (1864-1870), donde se enfrentó, quijotescamente, contra las fuerzas aliadas de Brasil, Argentina y Uruguay, sufriendo en el proceso la pérdida de más del $75 \%$ de su población ${ }^{1}$. A esa hecatombe nacional siguieron décadas de anarquía, golpes de estado, y se repitieron los regímenes dictatoriales y autoritarios hasta el otro gran enfrentamiento internacional, la Guerra del Chaco con Bolivia (1932-1935) que, a pesar del triunfo paraguayo, dejó al país humana y económicamente devastado. Un par de años de paz (1936-1937) y después otra vez la anarquía, gobiernos provisionales despóticos, una sangrienta Guerra Civil (1947), otro breve espacio de relativa tranquilidad y la instalación en el poder del General Alfredo Stroessner (en 1954) cuya dictadura, la más represiva y la más larga de los anales paraguayos, culminó en el golpe de estado del 3 de febrero de 1989. Desde entonces hasta el presente, trece años de un difícil proceso de transición hacia la democracia y un nuevo milenio de esperanzas para que dicho proceso tenga un final feliz...

He aquí, resumidos en un párrafo largo, los vaivenes y vicisitudes de la historia del $\mathrm{Pa}-$ raguay desde sus inicios como nación hasta principios del siglo XXI, historia enmarcada entre dos largas dictaduras, la del Dr. Francia (1814-1840) y la del Gral. Stroessner (19541989), y poco más de una década de ensayos y tentativas de democratización, hasta ahora muy frágiles. He aquí también los datos necesarios que explican, aunque sea en parte, el porqué de la escasez literaria paraguaya a menudo mencionada por estudiosos e historiadores de nuestra literatura y en particular por quienes la tratan de comparar y contrastar con otras literaturas hispanoamericanas.

Antes de tratar de aislar los núcleos temáticos recurrentes en la narrativa paraguaya del último cuarto de siglo, incluyendo aquí novelas y cuentos publicados a partir de 1974, dentro y fuera del país, es importante describir, a grandes rasgos, la situación de dicha narrativa antes de los años setenta. En particular, es necesario señalar algunas consecuencias del trágico derrotero histórico-político arriba deli- 
neado, irónicamente muy positivas para la narrativa paraguaya actual.

En primer lugar, y en términos generales, la narrativa ha sido el género menos prolífico de las letras paraguayas y el más afectado por el contexto histórico-político nacional. Hasta mediados del siglo XX predominó el ensayo histórico y en la escasa producción narrativa del período tendieron a prevalecer, como en el ensayo, las corrientes romántico-nacionalistas de exaltación del pasado y de afirmación de los valores espirituales del pueblo paraguayo, heroico sobreviviente de la catástrofe de la Guerra de la Triple Alianza2. Posteriormente, la Guerra del Chaco (1932-1935) que fue, según Andrew Nickson, «the bloodiest and most prolonged war in twentieth century Latin America...» ${ }^{3}$, tuvo, no obstante, consecuencias positivas en el plano literario al promover una toma de conciencia de la realidad nacional y la incorporación de temas significativos (la guerra, los problemas del agro y de los yerbales, la persecución política, el exilio, etc.) en la narrativa posterior ${ }^{4}$.

La Revolución Civil de 1947 que inició un proceso migratorio masivo, hasta hoy el más largo de su historia, y la dictadura de Stroessner que lo continuó durante tres décadas y media, llevaron al exilio - entre los miles y miles de paraguayos que se vieron forzados a dejar su patria - a un número muy grande de la intelectualidad del país. Muchos escritores, artistas, músicos, profesionales, etc., tuvieron que dejar su tierra natal para sobrevivir, separándose forzosamente de amigos y parientes. Estas dos tragedias histórico-políticas que durante casi medio siglo dividieron a la familia paraguaya, con consecuencias funestas para el país, tuvieron, sin embargo, un impacto muy positivo en el desarrollo y actualización de la narrativa paraguaya contemporánea. En efecto, una de las consecuencias culturales más significativas de dicho éxodo intelectual fue el quehacer literario de algunos escritores integrantes de esa emigración masiva del 47, como Augusto Roa Bastos, y de otros, como Gabriel Casaccia, que habiendo dejado el país antes, empezaron a publicar sus cuentos y novelas en Buenos Aires. Iniciaron así estos dos escritores (a los que se agregaron después varios más como Rubén Bareiro Saguier, Carlos Garcete, Lincoln Silva, Rodrigo Díaz-Pérez, etc.) la importante vertiente de la narrativa paraguaya del exilio cuyo «corpus» cuenta en su haber con un gran número de obras publicadas pero cuya vigencia caduca, termina, lógicamente, con la caída de Stroessner en 1989, al poder volver todos ellos, sin miedo ya a represalias, a su tierra natal. $Y$ hasta la fecha, casi todos han vuelto...

Es importante enfatizar, sin embargo, que el papel de la escritura del exilio fue fundamental y clave en la renovación de la narrativa paraguaya contemporánea. Pero es igualmente importante señalar el hecho de que las obras aparecidas fuera del país inauguran e incorporan una serie de temas prácticamente ausentes en la narrativa coetánea de dentro. En este trabajo se identifican algunos núcleos temáticos que inicialmente aparecen de manera recurrente en la producción del exilio, pero que reaparecen después, también recurrentemente, en la narrativa concebida y publicada intrafronteras. Con respecto a estas dos vertientes, la de dentro y la de fuera, hay que recordar que la narrativa paraguaya recién empezó a adquirir distinción y atención internacional en la década del 50, con la aparición en Buenos Aires de tres obras - La Babosa (novela, 1952) de Gabriel Casaccia, Follaje en los ojos (novela, 1952) de José María Rivarola Matto y El trueno entre las hojas (1953), la primera colección de cuentos de Augusto Roa Bastos- que rompieron con las tendencias narcisistas y mitificadoras prevalecientes y reincorporaron a la ficción el realismo crítico inaugurado por Rafael Barrett a principios del siglo XX pero prácticamente ausente en la narrativa publicada hasta entonces dentro del país.

En efecto, es también en la producción del exilio de los años 50, 60 y 70 donde se detectan por primera vez ciertos temas o núcleos temáticos entonces apenas soslayados o totalmente ausentes en la narrativa de dentro - como los relacionados con la crítica y denuncia de la realidad socio-política, el exilio, la reinterpretación o revisión de la historia, la dictadura... - pero que sí constituirán temática recurrente en la narrativa posterior, en particular de las últimas dos décadas del siglo $\mathrm{XX}$. Teniendo en cuenta el contexto socio-político, las tensiones, represiones y miedos vigentes en el Paraguay de Stroessner, es también fácil deducir que las obras actualmente
NOVELA MHPOHALEWHORA LA OUEWA II

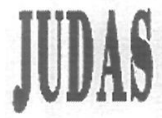

Cuarta edición DITORIAL COMUNEROS

a quema de Judas. Portada.

2

Dentro de esa línea tradicionalista, iniciada por el argentino Martín de Goycoechea Menéndez - glorificador de la Guerra Grande y mitificador de la literatura nacional - habría que mencionar las obras histórico-costumbristas de Natalicio González, Teresa Lamas de Rodríguez Alcalá, Concepción Leyes de Chaves y Carlos Zubizarreta.

3

Ver su Historical Dictionary of Paraguay, 2nd. ed. (Metuchen, N.J. \& London: The Scarecrow Press, Inc., 1993), pág. 118. Indica él también allí que "Some 60,000 Bolivians and 30,000 Paraguayans lost their lives, many from the effects of the harsh climatic conditions of the war-zone»,

4

Ejemplifican dicha renovación temática: Cruces de quebracho (1934) de Arnaldo Valdovinos, Ocho hombres (1934) de José Santiago Villarejo, ambas inspiradas en la guerra del Chaco, y especialmente El guajhú (1938) de Gabriel Casaccia, colección de cuentos donde su autor da el golpe definitivo a la visión literaria idealizada y romántica, totalmente falsa del campesino paraguayo.

Núcleos temáticos recurrentes en la narrativa paraguaya del último cuarto de siglo

TERESA MÉNDEZ-FAITH 


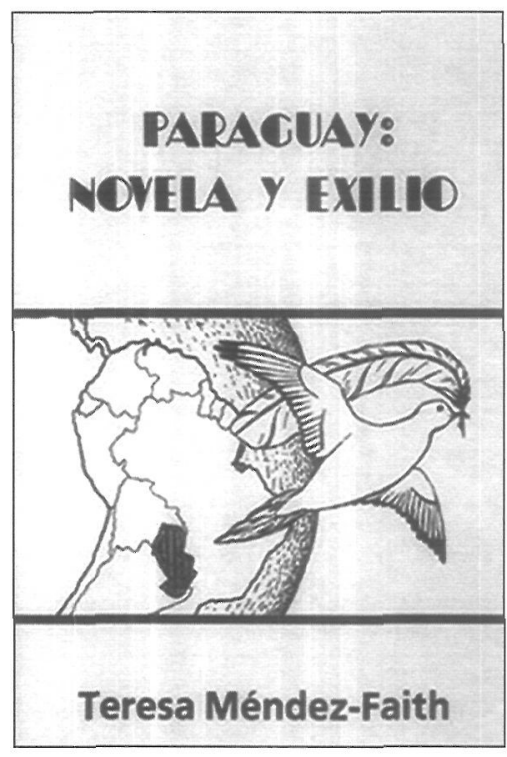

Paraguay: novela y exilio. Portada.

más conocidas hayan sido concebidas y publicadas en el exilio. Y esto por una razón muy sencilla: lejos del miedo, de las amenzas y posibles represalias, censuras y autocensuras asociadas con su país, a los escritores exiliados les fue posible expresarse libremente y desarrollar sin trabas una narrativa artísticamente elaborada, a tono con el momento histórico presente y de contenido socio-político significativo. Para los escritores que quedaron intrafronteras, escribir se convertía en un acto subversivo: contra el gobierno, contra la historia oficial, contra los escasos mecanismos de publicación y divulgación de la obra literaria. De ahí que fuera en los textos de esos expatriados ya antes mencionados - Rubén Bareiro

5

Es interesante constatar que mientras la narrativa concebida y publicada fuera del país produce varios iextos con el tema del exilio, en esos años hay solamente una novela publicada en 1965 en Paraguay: Imágenes sin tierra de José-Luis Appleyard.

\section{6}

Ver José Vicente Peiró Barco, estudio introductorio a Mancuello y la perdiz (Madrid: Ediciones Cátedra, 1996) de Carlos Villagra Marsal.

Núcleos temáticos recurrentes en la narrativa paraguaya del último cuarto de siglo

TERESA MÉNDEZ-FAITH
Saguier, Gabriel Casaccia, Rodrigo Díaz-Pérez, Carlos Garcete, Augusto Roa Bastos, Lincoln Silva y algunos más- donde se expresaron, inicialmente, tanto el planteamiento más directo como el reflejo más fiel de la problemática nacional de esas tres décadas y media (1954-1989) de dictadura stronista.

Gabriel Casaccia, iniciador de la narrativa paraguaya contemporánea, recupera de manera crítica varias décadas de descomposición moral y corrupción política en tres novelas: La Babosa, La llaga (1963) y Los berederos (1975), y dedica Los exiliados (1966) a tocar el tema del exilio político, prácticamente inexplorado en la narrativa intrafronteras ${ }^{5}$. Augusto Roa Bastos, Premio Cervantes 1989 , examina el presente y el pasado nacionales a lo largo de coordenadas histórico-políticas en Hijo de hombre (1960) - novela del dolor paraguayo- y en Yo el Supremo (1974), su segunda y más famosa novela, narrada desde la ubicua perspectiva del doctor José Gaspar Rodríguez de Francia, primer dictador paraguayo y una de las figuras más controversiales de la historia nacional. En ambos autores, el tema de la obsesión por el pasado permea prácticamente todas sus obras: en Casaccia, el pasado penetra la narración de manera indirecta e implícita, mientras que en Roa el pasado es un discurso constante, directo y explícito.

La dictadura, tema de difícil incorporación en la narrativa interna, está implícita o explícita en el miedo que atormenta a tantos personajes de las obras del exilio. Y se hace directa en su realidad de cárceles, torturas y persecuciones en varios cuentos de Rubén Bareiro Saguier -incluidos en Ojo por diente (1973) y en El séptimo pétalo del viento (1984) - y de Rodrigo Díaz-Pérez - contenidos en Entrevista (1978), en Hace tiempo... mañana (1989) y en Los dias amazónicos (1995) - como también en las dos novelas de Lincoln Silva: Rebelión después (1970) y General General (1975). Productos del destierro, aunque ya de fines de los 80 , son también dos obras inspiradas en la problemática de la dictadura: El collar sobre el río (cuentos) de Carlos Garcete y El invierno de Gunter (novela) de Juan Manuel Marcos, ambas publicadas en 1987. Como bien lo señala José Vicente Peiró en uno de sus trabajos sobre nuestra narrativa: «El año 1987 resulta clave porque se difunden tres novelas importantes que renuevan la narrativa paraguaya: Caballero, de Guido Rodríguez Alcalá (editada en Paraguay en 1986, y en Buenos Aires al año siguiente); El invierno de Gunter, de Juan Manuel Marcos, y La niña que perdí en el circo, de Raquel Saguier ${ }^{6} . »$ Comenta Peiró, en el mismo trabajo, que Caballero «representa la desmitificación de la sacralizada historia nacional», El invierno... «mezcla argumentos en una misma narración principal» y en La ni-

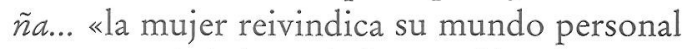
en una sociedad que la ha considerado como un ser marginal, con la ironía y la ingenuidad de la mirada infantil». Coincidimos con nuestro colega y amigo español que lo significativo de la aparición y difusión de estas tres obras en el mismo año es que «Las tres abandonan el maniqueísmo y los tópicos localistas, e incluso reinterpretan la historia y la realidad de las rígidas estructuras sociales del Paraguay tradicional» (de la misma introducción, pág. 29).

Teniendo en cuenta la propuesta y en realidad el eje de este trabajo -i.e., que gran parte de la temática recurrente en la narrativa de los últimos 25 años ya fueron captados/expresados en la narrativa del exilio de los años 50,60 y $70-$ es necesario puntualizar aquí que los temas recurrentes en las tres obras que acabamos de mencionar (aparecidas a fines del stronismo, en 1987), y en particular los relacionados con la reinterpretación o revisión crítica de la historia, ya están presentes y recurrentes en los cuentos y novelas de Casac- 
cia, Roa Bastos, Bareiro-Saguier, Lincoln Silva..., publicados en el exilio, antes de 1975.

Si empezamos con el núcleo temático en torno a la crítica y/o denuncia de la realidad socio-política nacional, debemos recordar que su expresión inicial se da en la ficción de Casaccia y Roa de los años 50 y 60: La Babosa (1952), La llaga (1963), Los exiliados (1966); El trueno entre las hojas (1953), Hijo de hombre (1960)... Este motivo se vuelve recurrente en varias obras del último cuarto de siglo, publicadas tanto dentro como fuera del país y escritas por escritores del exilio o de intrafronteras. En particular, está presente en novelas y cuentos de estos mismos autores, aparecidos posteriormente: Los herederos de Casaccia y un gran número de relatos de Roa incluidos en El baldio, Los pies sobre el agua, Madera quemada, Moriencia y otros, como también en la narrativa de Rubén Bareiro-Saguier, Carlos Garcete y Rodrigo Díaz-Pérez, con publicaciones posteriores a su retorno del exilio.

La misma temática de captación crítica de la realidad socio-política nacional, de denuncia de la violencia y la opresión, empieza a aparecer de manera recurrente en obras publicadas intrafronteras a partir de 1975. Tal es el caso de varios cuentos incluidos en El contador de cuentos (1980) de Jesús Ruiz Nestosa, Angola y otros cuentos de Helio Vera (1984), La seca y otros cuentos (1986) y Por el ojo de la cerradura (1993) de Renée Ferrer, Cuentos decentes (1987), Curuzú cadete (1989) y Cuentos (1993) de Guido Rodríguez Alcalá y Los hombres del sur (1987) de Catalo Bogado, Tierra mansa y otros cuentos (1987) de Lucy Mendonça, Papeles de Lucy-fer (1992) y En el pais de las mujeres (1995) de Jorge Canese, Memoria sin tiempo (1992) de Maybell Lebrón, La víspera y el día (1992) y Cuentos de tierra caliente (1999) de Dirma Pardo Carugati, Ora pro nobis (1993) de Neida Bonnet de Mendonça, Entre la cumbre y el abismo (1995) de Susana Riquelme de Bisso, Relatorios (1995) de Gilberto Ramírez Santacruz, y en varias obras más recientes. Esta mirada crítica al entorno de la realidad socio-política nacional también está captada en algunas novelas del último cuarto de siglo: entre ellas, en Función patronal (1980) de Alcibiades González Delvalle, Los nudos del silencio (1988) de Renée Ferrer, La vera bistoria de Purificación (1989) y Esta zanja está ocupada (1993) de Raquel Saguier, El destino, el barro y la coneja
(1990) y Donde ladrón no Llega (1996) de Luis Hernáez, Diálogos probibidos $y$ circulares (1995) de Jesús Ruiz Nestosa, para dar un número representativo de ejemplos.

En contraste con la temática de captación crítica de la realidad nacional en la ficción posterior a 1975 , el tema del exilio aparece ocasionalmente, aunque no de manera recurrente, en la narrativa de dentro (intrafronteras). Sin embargo, sigue siendo tematizado en las obras de los escritores asociados con el exilio (Roa Bastos, Bareiro Saguier, Díaz-Pérez...), escritas y publicadas en los últimos 25 años.

Otro núcleo temático inicialmente reflejado en la narrativa del exilio y que resulta bastante recurrente en la que aparece intrafronteras, durante el último cuarto de siglo, es el relacionado con la reinterpretación, re-creación, revisión crítica de la historia o de algún personaje específico de dicha historia. Si en 1960 Hijo de hombre pasa revista y recrea críticamente ciertos momentos de la historia nacional que van desde la época del Dr. Francia hasta los albores de la Guerra Civil del 47, incluyendo la agonía de la sed en la Guerra del Chaco, y si en Yo el Supremo, de 1974, es el supremo dictador y su período los que están en tela de juicio, revisados, re-creados y enjuiciados por las múltiples voces y documentos históricos reales y ficticios, son muchos los textos que desde fines de la década del 70 y especialmente a partir de los años 80 incorporan dichos núcleos temáticos al discurso narrativo. Se cuestiona y re-construye o re-interpreta la historia en Diagonal de sangre (1986) - novela que explora el contexto socio-económico-político en que se desarrolló la Guerra de la Triple Alianza- y en La isla sin mar (1987) de Juan Bautista Rivarola Matto, en Donde ladrón no llega (1996) de Luis Hernáez, donde se recrea la época de los jesuitas en 1767, el año de su expulsión, y en Vagos sin tierra (1999) de Renée Ferrer, centrada en la historia de una familia del siglo XVIII que emigra hacia el norte para colonizar unas tierras fronterizas con el imperio lusitano y aún dominadas por los indígenas. Se reconstruye un derrotero histórico personal en las novelas
Núcleos temáticos recurrentes en la narrativa paraguaya del último cuarto de siglo TERESA MÉNDEZ-FAITH 
Núcleos temáticos recurrentes en la narrativa paraguaya del último cuarto de siglo

TERESA MÉNDEZ-FAITH
Caballero (1986) y Caballero Rey (1989) de Guido Rodríguez Alcalá, dos versiones-revisiones de la figura del General Bernardino Caballero, héroe de la Guerra de la Triple Alianza, desmitificación de la carrera militar del personaje la primera obra y del hombre político la segunda, ambas cubriendo un período histórico que va de 1871 a 1887; y también en El fiscal (1993) de Roa Bastos, para mencionar media docena de novelas significativas.

El núcleo de temas que incluye el de la dictadura y el de la figura del dictador, igualmente estrenados en Yo el Supremo, está también muy visible en la narrativa de las últimas dos décadas. Si bien la figura de Stroessner está presente de manera implícita en Yo el Supremo (en los anacronismos referentes a la firma del tratado de Itaipú en 1973, por ejemplo), está explícitamente captado, revisado, criticado y denunciado en las novelas $\mathrm{Cel}$ da 12 (1991) de Moncho Azuaga, y en El rector (1991) de Guido Rodríguez Alcalá. También la dictadura está presente en el testimonio de la violencia y del terror que se ven expresados en muchos de los cuentos de Guido Rodríguez Alcalá (Cuentos decentes, $\mathrm{Cu}^{-}$ ruzú cadete, Cuentos), en las últimas novelas de Roa Bastos (El fiscal, Contravida y Madama Sui), en Tacumbú, infierno y gloria (1991) de Santiago Trías Coll, en Historia(s) de Babel (1992) de Lito Pessolani y en varias otras más. Igualmente significativas porque exploran en profundidad ciertas llagas dolorosas de la realidad paraguaya son obras que han ido apareciendo en los últimos años 15 años, entre ellas: Medio siglo de agonia (1994) de Santiago Dimas Aranda; Stroessner roto (1989) de Jorge Canese; Los nudos del silencio (1988) y Vagos sin tierra (1999) de Renée Ferrer; El caballo del comisario (1996) de Carlos Garcete; Demasiada bistoria (1988) de Sara Karlik, Diálogos probibidos y circulares (1995) de Jesús Ruiz Nestosa; Sin testigos (1987) de Roberto Thompson Molinas; y En busca del bueso perdido: Tratado de paraguayología (1990) y Angola y otros cuentos (1984 y 1994, 2a. ed. aumentada) de Helio Vera, prácticamente todas premiadas o finalistas en concursos nacionales de narrativa. En este grupo de obras la crítica a menudo se vuelve denuncia condenatoria del régimen dictatorial represivo y asfixiante de más de tres décadas.

Un aspecto interesante y significativo de la producción narrativa de las últimas dos déca- das - que además agrega otro par de núcleos recurrentes a la gama temática de la narrativa paraguaya actual - es la aparición de un alto porcentaje de voces femeninas en el panorama literario de este período más reciente. Más que en ninguna época anterior, dichas voces se manifiestan con gran fuerza y continuidad, y sus obras reflejan, temática y estructuralmente, preocupaciones y estilos diversos, a tono con la narrativa latinoamericana del último cuarto de siglo. Temas relacionados con la expresión de lo íntimo, del mundo interior, con la transgresión de la norma, la ruptura de tabúes, con la toma de conciencia de la realidad desde una perspectiva femenina, son motivos que amplían los núcleos temáticos recurrentes existentes hasta el momento y que coinciden con la irrupción de la mujer en el panorama narrativo del último cuarto de siglo.

Además de las obras de Renée Ferrer, ya antes mencionadas, hay que incluir en este grupo las de varias otras que se estrenan como narradoras en este período o que reflejan dichos temas (o algunos de ellos) en sus obras, entre ellas: Golpe de luz (novela, 1983) y Ora pro nobis (cuentos, 1993) de Neida Bonnet de Mendonça; las novelas de Raquel Saguier ya indicadas (La niña que perdi en el circo, La vera bistoria de Purificación y Esta zanja está ocupada) y La posta del placer (1999); La oscuridad de afuera (cuentos, 1987) y Presentes anteriores (1996) de Sara Karlik, y Tierra mansa y otros cuentos (1987) de Lucy Mendonça. Una variedad temática singular que se manifiesta en algunos cuentos del grupo más joven de escritoras (Delfina Acosta, Lita Pérez Cáceres, Milia Gayoso, Chiquita Barreto, Nila López, Amanda y Mabel Pedrozo), aunque todavía no se la podría calificar de recurrente, es el tema erótico que está presente en muchos cuentos de Con el alma en la piel (1994) y Delirios y certezas (1995) de Chiquita Barreto.

Otro núcleo temático importante que aporta la escritura femenina en estos últimos años es el de carácter ecológico y está representado especialmente por los cuentos ecológicos incluidos en Ecos de monte $y$ arena (1992) de Luisa Moreno de Gabaglio ${ }^{7}$ y los relatos que integran Desde el encendido corazón del monte (1994) de Renée Ferrer. Tampoco aquí podemos hablar todavía de una recurrencia temática pero sí de un nuevo aporte temático a la narrativa paraguaya actual. 
Para concluir esta rápida revisión de los núcleos temáticos recurrentes en la narrativa paraguaya del último cuarto de siglo, llaman la atención un par de cosas: en primer lugar, que los temas que recurren con más frecuencia en estas obras, tanto de escritores como de escritoras, son los mismos o muy relacionados con los núcleos temáticos ya reflejados en la narrativa del exilio de los años 50, 60 y 70, también omnipresentes en la narrativa hispanoamericana del último medio siglo en autores consagrados y de la fama de Gabriel García Márquez, Mario Vargas Llosa, José Donoso, Julio Cortázar, Juan Rulfo, Alejo Carpentier, Carlos Fuentes o Mario Benedetti. Y en segundo término, que la irrupción de la escritura femenina en Paraguay a partir de la década de los 80 sea paralela, incluso en aportes temáticos, a la que se produce en el resto de los países de Hispanoamérica con escritoras también muy conocidas como Claribel Alegría (El Salvador),
Isabel Allende y Marcela Serrano (Chile), Laura Esquivel, Angeles Mastretta y Elena Poniatowska (México), Rosario Ferré (Puerto Rico), Luisa Valenzuela (Argentina), Carmen Naranjo (Costa Rica), Cristina Peri Rossi (Uruguay) y otras. Llama la atención, en fin, la gran productividad narrativa actual pero al mismo tiempo ello es también consecuencia lógica de que las coordenadas histórico-políticas que condicionaron dicha producción por tanto tiempo, e impidieron o limitaron la producción narrativa hasta 1989 , hayan finalmente desaparecido y existe hoy libertad y más oportunidades para la tarea creativa de los escritores y escritoras de Paraguay. Celebro profundamente que en el último cuarto de siglo nuestro país haya dado muestras de tanta energía y productividad creativa ya que esto es augurio de un sólido «corpus» narrativo con una variedad temática «extra-ordinaria» para este nuevo siglo y milenio... 


\begin{abstract}
José Vicente Peiró Barco
Doctor en Literatura Hispánica por la UNED de Madrid, actualmente vinculado a la Unidad de Investigación de Literatura Hispanoamericana de la Universidad de Alicante. Especializado en literatura paraguaya, estudió la narrativa contemporánea de este país en su tesis doctoral, así como la obra de Roa Bastos en su memoria de licenciatura titulada Análisis de El Fiscal de Augusto Roa Bastos. Es autor de la edición crítica de la novela Mancuello y la perdiz de Carlos Villagra Marsal, para la colección «Letras Hispánicas» de la Editorial Cátedra, y de la antología Narradoras paraguayas junto al autor paraguayo Guido Rodríguez Alcalá, entre otras aportaciones al tema, además de artículos en revistas y de participar en congresos. Dirige el portal de literatura paraguaya de la $\mathrm{Bi}$ blioteca Virtual «Miguel de Cervantes» de la Universidad de Alicante. Actualmente, se encuentra a punto de editarse una recopilación de sus artículos más relevantes publicados en la prensa cultural paraguaya, prepara un estudio sobre la evolución de la narrativa paraguaya desde Yo el Supremo de Augusto Roa Bastos hasta el año 2000, y un acercamiento amplio a la poesía y al teatro paraguayo.
\end{abstract}

\section{1}

ROA BASTOS, Augusto: «La música y el carácter nacional paraguayo». Asunción, Revista del Ateneo Paraguayo, 17, febreromarzo (1947).

\section{2}

Omitimos fechas de nacimiento y defunción de los autores, para evitar que el lector se detenga en el dato, en lugar de prestar atención a las ideas. Para obtener cualquier dato se puede consultar Teresa Méndez-Faith: Breve diccionario de la literatura paraguaya. Asunción, El Lector (2 edición), 1997. Se puede encontrar esta obra en el portal de literatura paraguaya de la Biblioteca Virtual «Miguel de Cervantes» (www.cervantesvirtual.com).

\section{3}

AMARAL, Raúl: El modernismo poético en el Paraguay (19011916), Asunción, Alcándara, $2^{\mathrm{a}}$ edición, 1982.

MARINI PALMIERI, Enrique: prólogo de Eloy FARIÑNA NÚÑ̃EZ: Las vértebras de Pan, Asunción, Ediciones Ñandutí Vive / Intercontinental Editora, 1990, pp. 7-32.

Literatura paraguaya actual: poesia y teatro

JOSÉ VICENTE PEIRÓ BARCO

\title{
LITERATURA PARAGUAYA ACTUAL: POESÍA Y TEATRO
}

\author{
JosÉ VICENTE PEIRÓ BARCO
}

\author{
A Rudi Torga
}

Existe la certeza en el pensamiento de la intelectualidad paraguaya de que su país es tierra de poetas y no de narradores. A esta idea se ha añadido la continua afirmación de la carencia de tradición narrativa. Incluso se ha aludido a la ausencia de raíces populares de la poesía en español porque éstas pertenecen a la escrita o recitada en guaraní1. La poesía paraguaya actual se enfrenta a estos tópicos y a afirmaciones discutibles y cuestionables, y, sobre todo, a la inmensa hojarasca que la ha cubierto, dada la liviandad de una parte de las opiniones críticas y la inflación de poetas cuyas aportaciones son bastante limitadas y escasamente relevantes. Ante esta situación, cabría una interpretación que, sin desdeñar las aportaciones críticas anteriores, reordenara una visión de conjunto del género con un mayor grado de profundidad. En virtud de ello, se hace necesario un nuevo análisis de la evolución sustancial de la lírica paraguaya a lo largo de su historia.

Debemos comenzar por evaluar qué significa dentro de la historia y la evolución de la literatura paraguaya, imponiendo un criterio cronológico que nos permita adquirir una perspectiva amplia del mismo. La poesía ha sido el género literario por antonomasia en el Paraguay. De hecho, quien escribiera un poemario ya podía - y puede - ser considerado «autor literario», sin preocuparse en ocasiones por valores estéticos mínimos. La producción poética paraguaya, a lo largo de su historia, es notablemente superior a la de cualquier otro género literario, por lo menos hasta el último cuarto del siglo XX, quizá porque resultaba más cómodo y breve el dedicarse al verso como medio de expresión o por las mayores posibilidades de publicación dado el menor coste de las ediciones de obras líricas. De hecho, el gran autor de la literatura del país guaraní del siglo XIX es un poeta romántico-nacionalista cuyo tema dominante era el canto a las glorias de la patria como cronista del ejército del mariscal López durante la Guerra de la Triple Alianza (1864-1870): Natalicio Talavera ${ }^{2}$. Incursiones románticas al margen, la siguiente generación literaria paraguaya, la novecentista, se nutrió fundamentalmente de poetas y polemistas. Eugenio A. Pane, uno de los más destacados, demostró que el sentimentalismo se podía mezclar con la racionalidad de su generación. Los López Decoud, Juan E. O'Leary, Juansilvano Godoy o Ricardo Brugada, giraron la poesía hacia presupuestos más universales, pero sobre ellos acabó pesando el ambiente político nacional, lo que perjudicó notablemente a su inspiración $y$, por tanto, a sus temas y formas.

El Modernismo tuvo expresiones poéticas con peso específico en Paraguay. Los trabajos de Raúl Amaral y de Enrique Marini Palmieri así lo demuestran ${ }^{3}$. Se ha tenido en cuenta que el Canto Secular de Eloy Fariña Núñez ha sido su aportación más notable, pero son tanto o más modernistas las composiciones de Fortunato Toranzos Bardel. Parte de él desembocó en el llamado mundonovismo y en el nativismo, bien representados por el fortalecimiento de la poesía escrita en guaraní, sobre todo de la mano de Narciso R. Colmán, y por Natalicio González y Manuel Ortiz Guerre- 
ro, autor de bastantes letras de las guaranias que en los años veinte compusiera el músico José Asunción Flores. De ahí que mantengamos en vigencia las opiniones de Amaral y Marini-Palmieri mientras no aparezca otro nuevo estudio que ofrezca una nueva visión pormenorizada de toda la poesía paraguaya de las primeras décadas del siglo XX.

Durante estos años se aprecian temáticas universalistas como el anhelo de justicia en Gomes Freire Esteves, el metapoético con audacias estróficas en Guillermo Molinas Rolón, pero se imponen los versos amorosos, los panegiristas a los héroes de la historia paraguaya y los hímnicos en la mayor parte de ellos. La poesía, como el ensayo polemista o los géneros memorialísticos y autobiográficos, también participó de la revisión del pasado en tono nacionalista. El conjunto desembocó en la superación del Modernismo y de los temas neorrománticos para buscar un «más allá» sin alejarse de los problemas terrenales. Es la época que Raúl Amaral denomina Posmodernismo poético. La revista Juventud (1923-1926) atestigua estos cambios. Se abandona el gusto por la forma y se profundiza en los contenidos. Entre estos poetas - José Concepción Ortiz, Pedro Herrero Céspedes, Hérib Campos Cervera (padre), por citar algunos - destaca Julio Correa, que supo captar la esencia de la expresión paraguaya, mezcla de español y guaraní, para profundizar en el canto a los seres que sufren y el desvalimiento de las capas sociales más humildes.

Los atisbos de la vanguardia también necesitan una revisión. Generalmente, su influjo se ha retrasado hasta la llamada Generación del 40, en la que destacan Josefina Pla, Augusto Roa Bastos, Hérib Campos Cervera (hijo), Hugo Rodríguez Alcalá y Elvio Romero; la mayor parte, autores que emigraron por distintas circunstancias - políticas, económicas, profesionales y personales-, sobre todo a Argentina ${ }^{4}$. Heriberto Fernández escribió un poema vanguardista cuando residía en $\mathrm{Pa}$ rís en los años veinte, pero falleció poco después, mientras al Paraguay no llegaban esas nuevas corrientes que sí, en cambio, se recibían con fervor en Brasil y Argentina. Hubo contactos con algunos movimientos, como el creacionismo, pero no fructificaron en la práctica. La vanguardia afectó a la Generación del 40 cuando ya se imponían nuevos compromisos poéticos, como el social, cuyo represen- tante máximo es Elvio Romero. De hecho, el más considerado como renovador por influjo vanguardista, Campos Cervera, adquiere mayor tono en sus trabajos de temática social que por la práctica de procedimientos heredados de los «ismos», aunque su poesía rezume la humanización que se vislumbra en César Vallejo. De ahí que pensemos que la vanguardia no tenga hitos importantes en el Paraguay, al menos como los pueden tener otros países latinoamericanos, aunque existan muestras aisladas o influjos visibles en la poesía posterior a la década de los treinta, cuando presumiblemente las vanguardias entran en su ocaso. Se sigue cultivando una lírica más o menos tradicional formalmente, y los contenidos recogen temas amorosos, nacionales, sociales e intimistas preferentemente, hasta que la Generación del 40 irrumpe con la batalla por la renovación expresiva, en la que vence finalmente, sobre todo al mantener contactos con el exterior o proceder de fuera del país como es el caso de Josefina Pla. Será con esta generación cuando se inicie el camino de lo que denominaríamos poesía actual, motivo esencial de este trabajo, hecho además que se intensifica cuando pensamos en que algunos de estos autores están vivos y en activo, lo que les lleva a mezclarse con autores de apenas veinte años en el ámbito de la literatura paraguaya actual, en este tránsito de siglos.

Dejando al margen la labor poética de Roa Bastos, primeriza y augurio de su extraordinaria narrativa posterior, la poesía paraguaya posterior a 1940 más conocida es la de protesta social. Sobre todo Elvio Romero, cuyas obras Destino y atardecer (1962), Libro de la migración (1966) y Los innombrables (1974) son muestras de su mejor lírica. Su canto traspasa el Paraguay se hace eco de las preocupaciones latinoamericanas, razón que le permite conectar con la mejor poesía social del continente. Su importancia se percibe en que aparece en todas las selecciones de poesía paraguaya contemporánea, mientras el resto de autores incluidos varía.

Dentro del país, un amplio grupo de jóvenes se sienten atraídos por la lírica y se integra en la Academia Universitaria que dirige el sacerdote español César Alonso de las He-
HUGO RODRÍGUEZ-ALCALÁ

\section{EL PORTON INVISIBLE}

4

La tesis más o menos establecida es la de Hugo Rodríguez Alcalá, en «El vanguardismo en Paraguay", Pittsburg, Revista Iberoamericana, 118-119 (enero-junio 1982), pp. 241-255.
Literatura paraguaya actual: poesía y teatro

JOSÉ VICENT'E PEIRO BARCO 


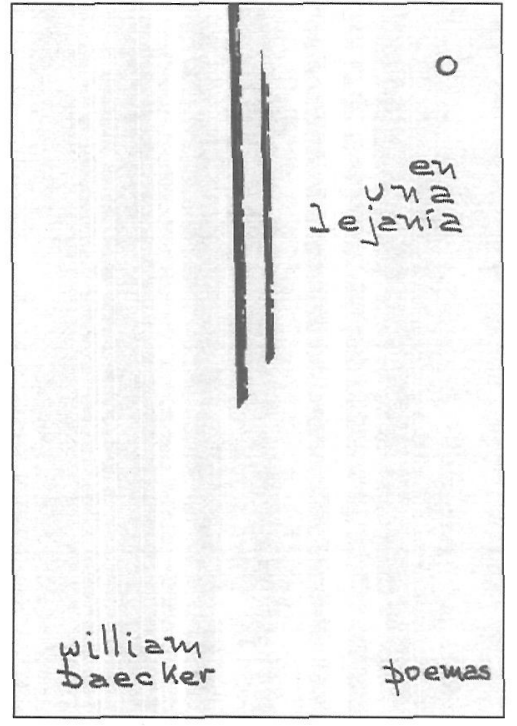

En una lejanía. Portada.

5 Roque VALLEJOS: La literałura paraguaya como expresión de la realidad nacional. Asunción, Editorial Don Bosco, 1971.

Literatura paraguaya actual: poesía y teatro

JOSÉ VICENTE PEIRÓ BARCO ras, bajo la consigna de «la conquista del Paraguay por la cultura», a partir del último lustro de los años cuarenta. Entre ellos se encuentran los mejores poetas del segundo tercio del siglo: el mismo César Alonso, Ricardo Mazó, Rodrigo DíazPérez, Ramiro Domínguez, Carlos Villagra Marsal, José Luis Appleyard, Rubén Bareiro Saguier, Gustavo Gatti, Luis María Martínez, Elsa Wiezell, María Luisa Artecona de Thompson, Gonzalo Zubizarreta y José María Gómez Sanjurjo. César Alonso les inculcó el estudio analítico de los poetas españoles del 27 y de otras figuras como Antonio Machado y Juan Ramón Jiménez, y su influencia se hizo notar en los jóvenes autores. Es un segundo momento donde la lírica del país trata de situarse en consonancia con las corrientes recientes, sobre todo de España. Hay intentos próximos a la poesía pura, al compromiso estético mezclado con el social y el deseo de transmitir mensajes. Es la búsqueda de una nueva expresión nacional, aunque en realidad estos autores aprovechan lo nativo para hallar la universalidad de sus temas y formas. Se renuevan las formas y aprovechan el camino abierto por la Generación del 40, sobre todo en la ruptura de las formas tradicionales, aun con el respeto suficiente para cultivarlas cuando fuera necesario, pero no por imposición genérica, para encontrar una lírica más auténtica, sin corsés y libre de trabas impuestas por las necesidades nacionales o personales, sin huir de los compromisos personal y social.

Julio César Troche y Rubén Barreiro Saguier crearon la revista Alcor (1953-1960) que fue garantía de expresión de estos autores y de otros noveles que surgían con mayor frecuencia cada vez. Los poetas se inspiraban ahora en temas universales como el tiempo, la belleza, el conocimiento, la pasión por las causas nobles, el humanitarismo, la ruptura de espacios de enclaustramiento, la transcendencia del lenguaje y la pintura del objeto inanimado con las sensaciones que produce, pero no desde el punto de vista impresionista o simbolista, sino puramente conceptual. Pero sobre todo, en esos años se impone el testimonio de la violencia y el odio generados por las disputas políticas, mezclados con la orientación intimista y el tono melancólico de parte de las composiciones.

En los años sesenta, los jóvenes discurrieron en paralelo a los acontecimientos internacionales. Aumentó la intensidad de la lucha contra la dictadura de Stroessner. Ello obligaba a una poesía combativa, pero a la vez a versos que analizaran las causas del enclaustramiento que sentían. Hubo un mayor deseo de libertad en todos los ámbitos, que desembocó en una pronunciada audacia formal de una lírica vehículo de denuncia de la injusticia y de la tiranía. Los versos no escondían la asfixia de los autores ante una situación agobiante hasta la claustrofobia y transmitían la angustia por el estado del país y su aislamiento. La poesía, de la misma manera que desde finales del siglo XIX hasta los años treinta del XX había sido útil para ensalzar la realidad nacional y crear una ideología patriótica perdurable, a partir de los sesenta era el instrumento idóneo para expresar el disgusto: con la sociedad, con la política... y con uno mismo. Nunca ha habido en Paraguay una lírica tan personal como la surgida a partir de estos años, cuando, en apariencia, la social predominaba.

Las revistas continuaron siendo el vehículo estelar para la divulgación lírica. Alcor proseguía su afianzamiento, mientras se editaban otras que, sin romper con sus postulados, ofrecían sus discrepancias de raigambre juvenil. De ellas hay que destacar Diálogo y Criterio (1966-1971). Miguel Ángel Fernández fundó la primera y en la segunda participaron José Carlos Rodríguez, Adolfo Ferreiro, Juan Manuel Marcos, Emilio Pérez Chaves, René Dávalos, Nelson Roura y otros. En todos ellos se percibe la angustia interior y la continuidad con los poetas precedentes. Quizá esta década sea una de las más fructíferas del siglo, dada la aparición, además de los susodichos, de obras líricas firmadas por Esteban Cabañas, Gladys Carmagnola, Raquel Chaves, Ovidio Benítez Pereira, Rudi Torga, Jacobo Rauskin, Osvaldo González Real, Francisco Pérez-Maricevich o Roque Vallejos. De todos ellos destaca como denominador común el que preconicen una poesía política y socialmente significativa, pero siempre, profundizando en la expresión de los autores anteriores, subrayando el negativismo, al decir de Roque Vallejos ${ }^{5}$. Las formas se simplifican, porque los autores abogan por el verso simple; por la esencia, en suma. 
En los setenta, el afianzamiento del régimen de Stroessner, favorecido por la aparición de dictaduras militares semejantes en los países vecinos, provocó el incremento de la represión. Como consecuencia, la poesía sociopolítica adquiere mayor protagonismo. El régimen no ve aún excesivamente como enemiga a la literatura y permite, hasta cierto punto, licencias que entenderá como fruto de los ociosos. Pero siempre pesará como una espada la autocensura sobre los autores. Se percibe el miedo y el deseo de encriptar los mensajes, ya por la vía del experimentalismo (Jorge Canese), ya por medio de la sugerencia implícita. El odio a la tiranía se percibe en obras como la de Guido Rodríguez Alcalá. Pero tampoco abandonan temáticas como el amor, en el caso de Miguel Ángel Caballero Figún, Aurelio González Canale o William Baecker, pero casi siempre en tono melancólico. Otros motivos son la evocación de la infancia (Juan Manuel Marcos) o la noche como símbolo de desconcierto (Víctor Casartelli). A la par, Renée Ferrer hace gala de una poesía intimista, de la voz de la mujer heredada del grito de Josefina Pla.

A finales de los setenta, se creó el Taller de Poesía «Manuel Ortiz Guerrero». Lo integraron Jorge Gómez Rodas, Moncho Azuaga, Jorge Aymar y Mario Rubén Álvarez. A ellos se fueron sumando nuevos poetas jóvenes (Miguel Ángel Meza, Augusto Casola, Ramón Silva, Victorio Suárez, Delfina Acosta, Ricardo de la Vega, Santiago Dimas Aranda, Amanda Pedrozo, Mario Casartelli, Pedro Céspedes, Susy Delgado y Mabel Pedrozo, todos nacidos a partir de 1950, salvo Aranda) que defendían el tomar contacto con las clases populares por medio de la poesía, para lo cual tomaron como primer objetivo el integrar el guaraní en su expresión lírica personal, y no sólo para narrar en verso o cantar la excelsitud del país, como ocurría hasta entonces. Creían en una poesía capaz de superar la dificultad de edición, por medio de la presentación de trabajos colectivos, pero siempre contando con el carácter individual de la creación, como un acto particular, aunque ligado siempre a la función social.

En los ochenta se produce un auge de la narrativa. Pero la poesía también experimenta un nutrido aumento de publicaciones. NAPA incorporó a sus colecciones de narrativa, una de poesía, donde destacan La llama y la arena de Josefina Pla o Leviatán etcétera de Guido Rodríguez Alcalá. Sin embargo, es en 1984 cuando surge el primer intento ejemplar de reunir la mejor poesía paraguaya: la colección Alcándara (1982-1987)6. Se convirtio en una verdadera «enciclopedia» de la lírica paraguaya. Incluyó a casi todos los autores más destacables, desde los de antaño como Martín de Goycoechea Menéndez (aunque no olvidemos que es argentino, pero la historiografía literaria paraguaya se lo apropia por haber vivido en el país y reflejar sus escenarios en las obras), Juan E. O'Leary y Alejandro Guanes, pasando por la generación del 40 (Roa Bastos, Josefina Pla, Hérib Campos Cervera, Elvio Romero y Hugo Rodríguez Alcalá), los poetas en plena madurez y los más jóvenes como Juan Manuel Marcos, Nila López o Susy Delgado. Alcándara fue un estímulo para los poetas, que ya no dejaron de publicar sus obras escritas, $y$, sorprendentemente, los editores obtuvieron beneficios económicos con ella.

Frente a las mayores posibilidades de edición, en cambio, las dificultades frente a la censura dictatorial aumentaron. Si hasta entonces el régimen de Stroesser había sido permisivo, hasta cierto punto, con el género, en 1982 prohibió con firmeza el poemario Paloma blanca, paloma negra de Jorge Canese, por incluir la expresión "este país de mierda». La prohibición afectó incluso al acto de la presentación del poemario, puesto que se suspendió por la expulsión del país de Augusto Roa Bastos, que había viajado para presentarlo, aunque finalmente se realizó por la valentía de Francisco Corral, director del Centro Cultural Juan de Salazar de la Embajada de España. El fantasma de la represión no impidió que con Alcándara se publicaran autores mal contemplados por el régimen, o que incluso las obras de Elvio Romero fueran declaradas de utilidad pública, tremenda contradicción. Al fin y al cabo, las obras secuestradas y prohibidas podían adquirirse en algunas comisarías, aunque a un precio más elevado.

A partir de Alcándara, la situación fue más halagüeña y proliferaron las colecciones poé-
6

Fundada por Carlos Villagra Marsal, José María Gómez Sanjurjo y Jorge Gómez Rodas.
Literatura paraguaya actual: poesía y teatro

JOSÉ VICENTE PEIRÓ BARCO 
ticas en algunas editoriales, hasta la actualidad. La caída de la dictadura provocó el nacimiento de una «poesía de alivio», que denunciaba y manifestaba un optimismo, a la vez, que con el tiempo se fue desvaneciendo a la luz del desencanto de la transición democrática. Jacobo Rauskin es uno de los exponentes de esta evolución. A la vez, surgían nuevos talleres, aunque más pedagógicos y sin el ánimo editorial del «Ortiz Guerrero», de donde nacieron nuevos poetas, sin distinción de edad. Poco a poco van predominando los temas intimistas y personales, y aunque la crítica social o política no se esfuma completamente, sí que no se desarrolla tan ampliamente. A la vez, el romance histórico adquiere vigor con Hugo Rodríguez Alcalá y Delfina Acosta. Y a finales de los noventa irrumpe en escena la autodenominada «Generación del 90», que surge de los universitarios de Humanidades. Centran su actividad en tertulias, recitales, contactos entre grupos literarios e incluso un manifiesto para alegar que la literatura no ha muerto. El libro colectivo El ombligo del mundo reunirá a noventa y nueve autores jóvenes, con el apoyo de los poetas consolidados Joel Filártiga, Emilio Pérez Chaves, Miguel Ángel Fernández, Luis María Martínez y Jorge Aiguadé. De estos autores jóvenes, hay dos a destacar: Saskia Saer y Marcelo Sarubbi, que caminan por una poesía vivencial e interrogativa. Los nuevos nombres (Rick Taylor, Iván González, Nelson Aguilera, Raquel Rojas, Lía Colombino, José Antonio Alonso, Moneca Laneri y Diana Villaverde) aportan frescura y temas de lo cotidiano. El tiempo los examinará.

Hemos dejado un apartado específico para la poesía escrita por mujeres, por la especificidad que ofrecía hasta la aparición de un amplio conjunto de autoras a partir de la década de los ochenta del siglo XX. También en la poesía, la mujer nunca ha estado ausente de su cultivo, pero siempre ha tenido que vivir la postración y la marginalidad, a pesar de que las autoras generalmente solían pertenecer a capas sociales ciertamente acomodadas. El primer poema publicado por una mujer, que se recuerde e la actualidad, es "La pecadora», de Marcelina Almeida, autora de posible origen uruguayo, que se incluyó en la revista $L a$ Aurora (1860) dirigida por Ildefonso A. Bermejo. Se recuerda el romanticismo de $\ll \mathrm{Al} \mathrm{Pa}$ raguay» de Ercilia López de Blomberg, los poemas que Serviliana Guanes, Josefina Sape- na Pastor (Blanca Lila), Enriqueta Gómez Sánchez e Inés Marsal publicaron en la prensa entre principios de siglo y la guerra del Chaco, el gusto afrancesado de Ida Talavera de Fracchia (próxima a la generación modernista de la revista Juventud, 1923), el nativismo intimista de Renée Checa en la década de los veinte, y la poesía erótica de Dora Gómez Bueno de Acuña, desde los años cuarenta. Ellas dieron una continuidad, minoritaria pero consistente, a la participación femenina en la evolución de la lírica paraguaya.

Pero por encima de todo está la labor de Josefina Pla, que evolucionó desde el posromanticismo de El precio de los sueños hasta la poesía existencial y vivencial de La llama y la arena (1987), pasando por la ruptura formal heredada de la vanguardia. Su poema «Piedra», contenido en esta obra, encierra el anuncio de la lucha y la postración que sufrió a lo largo de su vida por el hecho de ser mujer. pero siempre había ocupado un segundo plano hasta la aparición de Josefina, quien rompe con los esquemas sociales tradicionales. Prueba de su herencia e importancia es el testimonio de las autoras actuales más jóvenes, que se declaran herederas del espíritu de Josefina Pla.

Años más tarde, María Luisa Artecona de Thompson y Elsa Wiezell se implicaron en la Academia Universitaria dirigida por César Alonso, a la que hemos aludido. Ellas abogaron por la poesía de la psicología femenina y como refugio frente a la marginación social a que les empujaba el mundo público. En paralelo, Ester de Izaguirre publica sus primeros poemas en la revista Alcor, antes de emigrar a Argentina, donde residirá hasta hoy en día y cultivará predominantemente poesía existencial.

$Y$ las generaciones siguientes fueron incrementando el número de mujeres dedicadas a la lírica: Noemi Ferrari de Nagy, Carmen Soler, Gladys Carmagnola, Renée Ferrer, Maybell Lebrón, Nilsa Casariego, Leni Pane, Miriam Gianni, María Elina Pereira de Olmedo, Raquel Chaves, Lilian Stratta, María Eugenia Garay, Susana Riquelme, María Carmen Paiva, Elinor Puschkarevich, Nidia Sanabria... tantas que resulta casi imposible realizar un inventario completo dada la dispersión de su obra. La siguiente generación ofreció un conjunto de autoras que acentuaron su defensa de la libertad de la mujer e intensificaron el ero- \begin{tabular}{c}
$\begin{array}{c}\text { Literatura paraguaya a } \\
\text { poesía y teatro }\end{array}$ \\
\hline
\end{tabular} JOSÉ VICENTE PEIRÓ BARCO 
tismo y la sensualidad. Algunas destacan por el uso de la ironía para satirizar al hombre y su dominio social. Ejemplos son Susy Delgado (autora de poemarios bilingües), Carmen Casartelli, Amanda Pedrozo, Nila López Lourdes Espínola o Delfina Acosta, que cultiva también poesía laudatoria a su pueblo o a Pablo Neruda. La última poesía incide en lo misterioso y en la vida cotidiana, y en el caso de Montserrat Álvarez en la noctunidad como ocurre en Zona dark y Underground, obras de atmósferas viciadas y ocultas a la vida que es noticia de prensa, como cantos a la libertad que permite la noche.

Un espacio, antes finalizar, merece la poesía en guaraní. Generalmente recitativa, predilecta para el caso (Juan Maidana), se adentra en temáticas más universales y va abandonando el localismo. Destaca el intimismo de Feliciano Acosta, Susy Delgado y Miguel Ángel Meza, la nostalgia de Rudi Torga, el lamento ante los problemas nacionales por medio de un ejercicio expresivo minimalista de Zenón Bogado Rolón, la inquietud social de Eulogio Zárate, el amor y el canto a la libertad de Lino Trinidad Sanabria, la ironía social crítica y el alumbramiento del estallido popular de Ramón Silva, y el canto social e indigenista de Félix de Guarania. Lo más importante no sólo es la amplitud temática que ha ido adquiriendo la poesía en guaraní desde finales de los setenta, sino el tratamiento expresivo innovador, personal, lo que ha provocado que los autores alcancen la perfección formal de los que escriben en español. De hecho, en la clasificación que desarrollamos para culminar este artículo, no hemos separado los autores en guaraní del resto, dada la similitud temática y formal que se aprecia en todos ellos, porque sólo se diferencian por la lengua empleada, y ya no por los temas.

Por sintetizar este breve recorrido, en la poesía paraguaya actual, donde conviven distintas generaciones, desde la llamada de los 40, hasta los más jóvenes que apenas sobrepasan los veinte años, hallamos varias tendencias que enumeramos':

1) Poesía minimalista (William Baecker y Zenón Bogado Rolón)

2) Poesía experimental (Jorge Canese, Joaquín Morales, Jorge Montesino)

3) Poesía sociopolítica (Gilberto Ramírez Santacruz, Elvio Romero, Luis María Martínez, Moncho Azuaga)
4) Poesía reflexiva (José Luis Appleyard, Manuel E. B. Argüello, Rubén Bareiro Saguier y Juan Manuel Marcos)

5) Poesia de reivindicación femenina (René Ferrer, Gladys Carmagnola, Susy Delgado, Delfina Acosta)

6) Neoimpresionismo nativista (Carlos Villagra Marsal, José Antonio Bilbao)

7) Poesía existencial (Augusto Casola, Ester de Izaguirre, Guido Rodríguez Alcalá)

8) Indigenismo (Félix de Guarania, Santiago Dimas Aranda, Ramiro Domínguez)

9) Poesía amorosa (María Elina Pereira, Ricardo de la Vega, Ester de Izaguirre)

10) Poesía erótica (Renée Ferrer, Nila López, Lourdes Espínola, Amanda Pedroso)

11) Poesía intimista (Gladis Carmagnola, Nilsa Casariego, María Eugenia Garay, Maybell Lebrón, Elinor Pushkarevich, Feliciano Acosta)

12) Poesía de la experiencia (Jacobo Rauskin, Ricardo de la Vega, Víctor Casartelli, Francisco Pérez Maricevich, Moncho Azuaga)

13) Poesía mítica (Raquel Chaves, Ramiro Domínguez)

14) Poesía oscura (Montserrat Álvarez)

15) Poesía expresiva-interrogativa (Marcelo Sarubbi, Saskia Saer)

16) Romance histórico (Hugo Rodríguez Alcalá y Delfina Acosta)

17) Poesía infantil (Nidia Sanabria, Renée Ferrer, Elly Mercado de Vera, Feliciano Acosta).

Este ensayo clasificatorio demuestra la riqueza de tendencias de la poesía paraguaya actual. Obviamente, los autores discurren por varias de ellas a lo largo de su trayectoria, aunque los hemos ubicado en una donde destacan. Un autor no ofrece una obra monocorde, por lo que no se le debe encasillar en esta clasificación. Son necesarios nuevos acercamientos con criterios que la escasa perspectiva temporal de que disponemos nos impide hallar. Lo cierto es que la poesía paraguaya muestra una riqueza singular y una proliferación de obras publicadas desde los ochenta sin parangón a lo largo de su historia. Ha superado tópicos, y sin abandonar sus raíces, ha adquirido mayor amplitud temática, como la narrativa, y se ha convertido en un medio de expresión universal.

\section{ESENCIAS DEL TEATRO PARAGUAYO ACTUAL}

El teatro en Paraguay posee raíces ancestrales. Su origen se remonta a la dramatización

\section{7}

Citamos sólo hasta cuatro autores por cada tendencia para evitar que la nómina sea interminable. 
Rudi TORGA: "A modo de introducción: reflexiones en torno al teatro paraguayo de ayer y de hoy». En Teresa MÉNDEZ-FAITH edit.: Tearro paraguayo de ayer y de hoy. Asunción, Intercontinental Editora (Tomo 1), 2001, págs. 15-44.

\section{9}

Teresa MÉNDEZ-FAITH: Breve diccionario de la literatura paraguaya, Asunción, El Lector $\left(2^{g}\right.$ edición), 1997, pág. 255.

10

Lastimosamente, buena parte de los documentos teatrales paraguayos no han llegado a nosotros. Este material fue expurgado en determinadas épocas de los archivos de Asunción, hasta el punto de que desaparecieron muchísimas obras y documentos.

11

Para examinar la labor de Fernando Oca del Valle, ver mi artículo «Teatro paraguayo contemporánea: Fernando Oca del Valle». Valencia, Sticomythia, Universidad de Valencia, $\mathrm{n}^{\circ} 0$ (arrículo nำ7), enero 2002.

Literatura paraguaya actual: poesía y teatro

JOSÉ VICENTE PEIRO BARCO de las danzas rituales que ejecutaban los aborígenes en la selva, cuyo objetivo era la reconstrucción de la armonía de los seres con su comunidad y con la naturaleza, como expresa Rudi Torga ${ }^{8}$. Era una teatralización religiosa repleta de simbolismos.

Los conquistadores españoles aprovecharon esta «afición» ceremonial para adoctrinar a los aborígenes guaraníes. El teatro fue un instrumento de propaganda muy útil para ellos. El adocenamiento solía fundamentarse en la escenificación de historias bíblicas, vidas de santos, la pasión de Cristo y las representaciones del Corpus Christi. Estas escenificaciones se atestiguan desde el último tercio del siglo XVI, sobre todo en los recintos de las misiones, que dieron lugar al conocido como teatro jesuítico (1607-1767). Fuera del ámbito religioso, según Torga, el teatro colonial no dejó una herencia con peso específico.

El siglo XIX no nos lega testimonios de grandes eventos dramáticos. Sí es cierto que se celebraron representaciones. De antes del final de la Guerra de la Triple Alianza, en 1870, destaca Un paragnayo leal del español Ildefonso A. Bermejo, obra compuesta al calor protector del gobierno de Carlos Antonio López, de carácter romántico y panegirista. El teatro resistió los avatares con tenacidad, igual que otros géneros como la narrativa. Y simplemente resistió. Los textos no vieron la luz y tampoco se recuerdan las representaciones en la prensa de la época, como se desprende de la laguna que muestran los textos críticos de carácter arqueológico que existen. De hecho, sólo se menciona un estreno, La cámara oscura de Alejandro Guanes, y con disparidad entre la crítica, que tildó la obra de escabrosa y de dudoso gusto, y el público, que aplaudió unánimemente la representación. Este estreno es de 1899. Antes, el desierto.

El teatro se encauza en Paraguay y se moderniza a partir de la década de los años veinte del siglo XX. Según Torga, arranca en 1922, con El crimen de Tintalila de Manuel Ortiz Guerrero, y otras obras de ese año y los siguientes como La chispa robada y Mboraybu ha tesay de Francisco Martín Barrios, La epopeya del mariscal de Eusebio Aveiro Lugo, La inquisición de oro de Leopoldo Ramos Giménez, Guaviramí de Benigo Villa, Juguete roto de Facundo Recalde, Sorprendidos y desconocidos de Luis A. Rufinelli, La marca de fuego de Arturo Alsina y Mboraybu paba de Félix
Fernández. Estas obras dan un giro a la exigua escena en guaraní y en español. Son aceptadas por el público porque incorporan motivos populares y temas de la vida cotidiana. Arturo Alsina, por citar uno de los más relevantes, se sumerge en la decadencia de la clase dominante desde tesis ideológicas naturalistas.

El teatro paraguayo sufrió una renovación importantísima a partir de los años treinta con la aparición de Julio Correa. Como consecuencia de ello, en el ambiente de los años cuarenta había dos grupos claramente distinguidos. Por un lado se situaba la corriente de José Arturo Alsina, partidario de un teatro universal, que sin huir de lo particular no cayera en el folclorismo, y cuyo drama de resonancias pirandellianas, al decir de Teresa Méndez-Faith', El derecho de nacer (1925), es el mejor ejemplo de su creación; por otro, la del teatro en guaraní, o al menos con un empleo importante de esta lengua, cuyos antecedentes se remontan a algunos de los autores susodichos de 1926, cuya expansión y éxito llegaría en la década de los treinta con Julio Correa, considerado por los críticos como el impulsor del teatro marcadamente popular, cómico, que tendía a la oralidad, a la técnica intuitiva y a los condicionamientos lingüísticos ${ }^{10}$. Este autor impulsó una suerte de teatro que llegaba mayoritariamente al público por el simple motivo de que reproducía temas de preocupación popular y la situación oral bilingüe del país. Los asistentes a las representaciones entendían sus obras, por el componente decisivo de esta lengua, y participaban en ellas en mayor grado que en las puestas en escena de obras de otras vertientes, ya que, generalmente, el conjunto del teatro paraguayo de esa época se encontraba bastante anquilosado en un posromanticismo vacuo y en procedimientos con olor a naftalina, a pesar de los intentos de Alsina. Es importante, además, porque se percibía un fondo social con el que sintonizaba el público.

En los años cuarenta del siglo pasado, Roque Centurión Miranda y otros nombres emprendieron la renovación definitiva del teatro paraguayo y se acercaron a las instituciones con el fin de asentarlo. En esta renovación participaron dos españoles, sobre todo en el ámbito pedagógico: Josefina $\mathrm{Pla}(1903-1999)$ y Fernando Oca del Valle (1893-1972)11. La actividad dramática contaba con el apoyo del Ateneo Paraguayo y de la Escuela Municipal 
de Arte Escénico, fundada por Centurión en 1948. Josefina Pla y Roque Centurión trabajaron juntos, como en los dramas Desheredado y Aqui no ha pasado nada. La importancia de ambos radica en su intento por mostrar una escena más sofisticada y con atención a temas universales y problemas generales, dejando en un segundo plano, aunque nunca abandonado completamente, el elemento popular o la preocupación por la lengua a utilizar. El tema del conflicto de la paternidad responsable frente a la doble moral de la sociedad de Aquí no ba pasado nada es el mejor ejemplo del camino de ambos autores. En esa década, se inicia la publicación de obras teatrales por parte de la Imprenta Nacional.

La tarea docente y tallerística prosigue y se crea un elenco de actores que, a pesar de que no terminan con algunos tics completamente, como la grandilocuencia y la rimbombancia de la dicción, pone las bases de la escena actual. El número de autores aumenta y particularmente adquiere notoriedad el teatro de reparto. Aumenta la representación de clási$\cos$ y autores vivos españoles, junto a los paraguayos, favorecidos por la proximidad de algunos exiliados. Ello acerca la situación del teatro del país a la de sus vecinos. Se puede afirmar que las formas interpretativas de Margarita Xirgu también influyeron en los actores.

Pero vayamos a los hitos más representativos del teatro paraguayo actual. La comedia social tiene como principal representante a Néstor Romero Valdovinos, quien desde Buenos Aires, supo captar la esencia del sufrimiento de los hombres paraguayos. Su obra Mbokaja ba'eño (Cocotero solitario) fue uno de los textos más representados en los años setenta. Es el verdadero continuador de la comedia de Julio Correa, desde la profundidad de contenidos y conocimiento maduro del oficio dramático.

A partir de los sesenta, Mario Halley Mora se convierte en el autor con mayor éxito en la escena contemporánea, no solamente desde el punto de vista del número de seguidores entre el público, sino por aprovecharse, como creador, de su posición dentro del régimen de Stroessner. Se le puede considerar como el dramaturgo más comercial. Su prolífica producción suma más de sesenta títulos, de dispar calidad. Como su narrativa, Halley Mora examina la realidad que contempla, la introduce en argumentos atractivos para el público, y presenta personajes humanos y de vivencias palpables. Sea cómica o trágicamente, siempre existe una visión crítica del materialismo al que ha llegado la sociedad, y su visión suele ser escéptica ante la infravaloración del hombre.

El tema político va adquiriendo mayor empaque a medida que aumenta la represión de Stroessner. Los dramaturgos lo cultivaban, sobre todo los exiliados, como es el caso de Hérib Campos Cervera. Pero desde finales de los cincuenta es difícil encontrarlo sin que recurra a símbolos o alegorías que encubran la denuncia. Ocurre en las obras de Ovidio Benítez Pereira. Algunos exiliados, en cambio, son más directos en la crítica, como Carlos Garcete, autor de La caja de fósforos. José María Rivarola Matto prefirió penetrar en la crítica del poder y del despotismo desde la reflexión y la sensibilidad, con obras como $S u$ señoría tiene miedo o El fin de Chipi González. Pero en esta obras destaca también el ingenio y el buen sentido del autor, frente a la seriedad habitual que domina en el tratamiento del tema político.

El teatro de vanguardia e independiente anticipa sus frutos a partir de la década de los sesenta. Osvaldo Dragún fue uno de los impulsores, adoptando precedentes del grotesco y del absurdo. Muchas veces instrumento de resistencia cultural en la dictadura de Stroessner, desde la innovación textual, prosigue con la ruptura de los elementos paratextuales. Ello hasta desembocar en el teatro callejero, cuya figura principal es Moncho Azuaga, autor de Los niños de la calle, que supo sacar a los espectadores de las salas para denunciar la falta de compromisos sociales auténticos. Luis Hernáez también ha sacado la escena a la ca1le. De su evolución nos dará cuenta la estudiosa Edda de los Ríos más adelante. Pero no hay que obviar que del teatro independiente han surgido autores importantes y directores de relieve como José Luis Ardissone y Raquel Rojas.

Particular expansión ha experimentado el teatro histórico desde los años setenta. Vino favorecido por el ánimo de criticar y examinar el presente partiendo del pasado. En el caso de Ramiro Domínguez, con Cantata beroica a Pedro Juan Caballero (1972), superó el historicismo para penetrar en las raíces del teatro poético. Muy recurrente fue el tema del ma-
Literatura paraguaya actual: poesía y teatro

JOSÉ VICENTE PEIRÓ BARCO 
Como nos explicó Edda de los Ríos, y hemos podido constatar, González Delvalle surge en los años sesenta como autor de zarzuelas paraguayas y madura en los 70 convirtiéndose en dramaturgo de hecho al incorporarse al grupo Aty Ñeé. Escribe las primeras obras de su nueva época con Antonio Carmona y juntos realizan las primeras versiones de Brecht. Su incorporación al drama histórico se produce cuando ya ha adquirido una amplia experiencia teatral. riscal López. La agonía del héroe (Francisco Solano López o el valor moral) de Efraín Enríquez Gamón (1975) es un ejemplo. Era una defensa del presunto valor moral de López, como símbolo de todo un pueblo. Este autor formó en el curso de los años una Tetralogía paraguaya. Pero, sin duda, las obras más impactantes sobre el conflicto fueron las de Alcibiades González Delvalle ${ }^{12}$ : Elisa, San Fernando y Procesados del 70. Trató de dar una dimensión humana a los héroes, deformados por la historia oficial. El autor cuestiona el retoricismo patrioterista, al contrario que Enríquez Gamón, y despierta un proceso a quienes fueron los protagonistas de la historia paraguaya. Sin embargo, el fondo escondía una crítica a la dictadura, que así lo entendió y emprendió una campaña contra la obra San Fernando, alegando que difamaba al mariscal y su antiparaguayidad, hasta prohibirla en diferentes ocasiones (incluso la prohibió Rodríguez en plena transición democrática).

Héctor Micó explora la realidad nacional desde la historia convertida en farsa política. Gloria Muñoz, autora plenamente dedicada al mundo dramático, escenificó Almirante de sueños y vigilia, que plantea el asunto de qué punto de vista emplear para examinar la historia, con el pretexto de la vida de Colón, para proclamar la necesidad del retorno a las raíces históricas. Esta autora adaptó la novela Yo el Supremo de Augusto Roa Bastos a la escena.

Este autor, toma este mismo sentido, en $\mathrm{La}$ tierra sin mal, donde reproduce la dialéctica entre jesuitas e indígenas, con el fondo de la utopía que expresa el título. Situada en 1767, año de la expulsión de la orden, nos muestra otra dicotomía: el «ser» y el «tener».

En los años ochenta aumenta el número de autoras dedicadas a la escena. El mayor intimismo y los problemas femeninos adquieren mayor presencia. En los años cincuenta, habían destacado Concepción Leyes de Chaves, Josefina Pla, Mariela de Adler y Gilda de Fretes. Pero en los ochenta, la mujer aprovecha la escena para mostrar sus preocupaciones. Además de la susodicha Gloria Muñoz, los dramas de la vida adquieren vigor en autores como Pepa Kostianovky. Renée Ferrer apuesta por el tratamiento poético de la puesta en escena de los problemas, sobre todo femeninos, como en La colección de relojes. Edda de los Ríos, también formidable actriz que ha conducido al teatro paraguayo a escenarios de todo el mundo, transforma el vacío de la cotidianidad en problemática que alcanza los límites de la tragedia, con obras como $Y$ abora... ¿qué? y Kuña rekove.

Dentro del proceso de «intimización» de la escena paraguaya, Agustín Núñez penetra en los conflictos humanos y ámbitos sociales y familiares, como en Domingo de fútbol o Arroz con leche, aunque también es conocido por sus adaptaciones escénicas de Hijo de Hombre de Roa Bastos, Pedro Páramo de Rulfo y Un señor muy viejo con unas alas enormes de García Márquez, todas estrenadas.

El teatro en guaraní, cada vez más representado, tiene su estandarte en la obra de Félix de Guarania, quien se inspira generalmente en motivos populares. A finales de los setenta, un juez de la era stronista, Antonio Escobar Cantero, compuso una obra sorprendente titulada Tekojojá, al haber sido escrita por un autor con un cargo importante dentro del sistema, que denunciaba los abusos y arbitrariedades de la justicia durante esos años. La obra estaba escrita en un guaraní muy cerrado, y aún se representa de cuando en cuando en la escena paraguaya actual.

Mario Santander es el mejor representante de los autores que comenzaron a escribir y estrenar textos en los años noventa. Teatro de problemática urbana, enfoca inquietudes que parten de la vida cotidiana para reflejar el desconcierto actual. Formado en estudios teatrales estadounidenses, fue el impulsor y director del texto de creación colectiva titulado $\mathrm{Muje-}$ res, compuesto de diez breves partes, estrenada en 2001.

Hasta aquí el breve, e intenso, recorrido por la trayectoria del teatro paraguayo a través de su historia. Salvadas grandilocuencias y retoricismos de antaño, presenta un panorama cada vez más amplio, no sólo en autores, sino en elencos importantes y directores conocedores del oficio, como José Luis Ardissone, Raquel Rojas o el recientemente fallecido Rudi Torga, o los citados como autor, Mario Santander y Agustín Núñez, y la labor investigadora de Edda de los Ríos.
Literatura paraguaya actual: poesía y teatro

JOSÉ VICENTE PEIRO BARCO 
Actriz, ensayista; periodista, dramaturga y docente del teatro, nacida en Asunción en 1942. Estudió en la Escuela Municipal de Arte Escénico de Asunción, y posteriomente realizó su posgrado en Arte Dramático y Comunicación en Argentina, Uruguay y España. Asimismo, Edda de los Ríos ha dirigido programas culturales en radio, televisión y prensa de su país. Como actriz protagonizó más de sesenta obras teatrales del repertorio universal, y como autora dramática ha estrenas las obras ¿Qué hacemos esta noche? (1975), Esta noche nos quedamos en casa (1977) y Kuña rekové (2001), obra representada en la edición del Festival Iberoamericano de Cádiz del año 2001. Ha participado, además, como miembro de jurado, ponente, invitada especial o coordinadora en distintos congresos, seminarios, foros y festivales de teatro realizados localmente y en países de América y Europa.

\section{ANTECEDENTES}

La producción dramática paraguaya se desarrolla en castellano y guaraní, lenguas que determinan su división en dos vertientes que datan del período de la colonia: 1) la del Teatro Colonial, compuesta por autos sacramentales y obras españolas de la época, representadas en castellano por españoles y criollos, y 2) la del Teatro Misionero surgida con los Jesuitas que iniciaron a los indígenas en la representación de autos sacramentales y misterios en castellano, latín y guaraní con propósito evangelizador Muy pronto el entusiasmo de los indígenas por este género los llevaría al intento de una dramaturgia local en lengua autóctona, que no pasó de simples divertimentos o piezas breves.

La prolongación de ambas, a través de los siglos, confluye en la corriente llamada Teatro Culto, con repertorio universal de habla castellana, dirigida al público de ascendencia europea, y en la del Teatro Popular, con temática local en idioma guaraní, ignorada por ese público, pero muy celebrada por el pueblo en locales marginales.

A principios del siglo XX, el teatro popular había desaparecido. La tradición oral preservó fragmentos que resurgían en festejos populares entremezclados con novedades sustraídas de espectáculos provenientes del exterior que se constituyeron en base de la reconstrucción del teatro popular que hizo del idioma guaraní su principal instrumento y que alcanzó reconocimiento con su acceso al escenario del primer coliseo del país en 1933. Julio Correa, su creador, consolidó ingenuos inten- tos de teatralidad, basados en juegos dramáticos o sucesión de escenas jocosas, improvisadas y yuxtapuestas sin estructura ni enlaces causales, en madura producción dramática que luego de años de marginación por un sector del público, logró imponerse y convivir con la otra tendencia.

Pero la actividad teatral, la formación de compañías o grupos de trabajo en forma más o menos permanente, surgió a mediados de siglo, con directores paraguayos o extranjeros radicados en el país, que produjeron las primeras puestas sobre esquemas tradicionales, entre las que no deben descartarse a aquellos que centraron su labor en el teatro popular, alcanzando nivel profesional por recorrer la capital e interior del país en constantes giras.

Desde entonces ambas corrientes compartieron tanto el escenario del Teatro Nacional, que más tarde pasaría a ser Municipal, como el de las salas privadas existentes y compañías surgidas con posterioridad, se inscribieron en una u otra de estas bien definidas tendencias.

\section{$1960-1970$}

La alarmante situación política y el estancamiento en el plano del arte, impulsó a un grupo de jóvenes actores a rebelarse contra las normas establecidas, a declararse «independiente» y a acoplarse a un movimiento que, nacido y asentado en Buenos Aires bajo esa denominación, renovó la dramaturgia rioplatense y se extendió a nuestro medio a principios de los 60 .

Uno de sus principales cultores, Osvaldo Dragún, definió su escritura como el grotesco
Dos décadas de teatro independiente en Paraguay

EDDA DE LOS RÍOS 


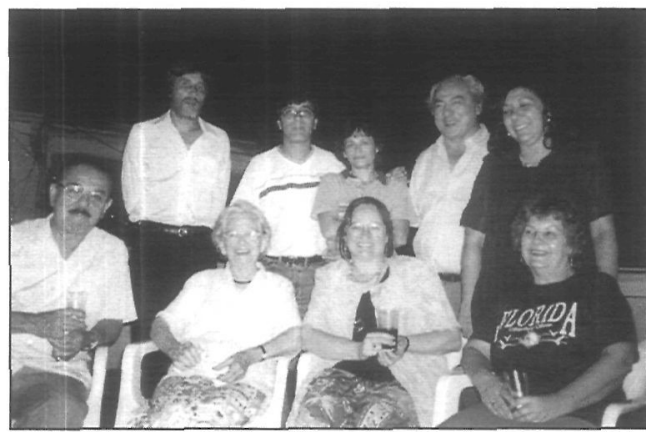

Fiesta teatro, con Rudi Torga de pie, segundo por la derecha y Teresa Méndez-Faith, sentada segunda por la derecha (Foto: Teresa Méndez-Faith). criollo para evitar categorías importadas, como la del Teatro del Absurdo, donde se la pretendió encasillar, sosteniendo que este género se nutría de sainetes criollos y del viejo teatro itinerante argentino y platense.

En la capital del Paraguay, el Teatro Independiente trabajó, en principio, con obras importadas. Su principal aporte, acorde con la filosofía del movimiento, fue la ruptura con centros comerciales u oficiales de cultura y la búsqueda de otras alternativas, espacios, públicos y esto se tradujo en nuevas temáticas y formas menos esquemáticas de producción y realización.

El Teatro Experimental de Asunción (TEA) fundado por Tito Jara Roman fue el primero en definirse como Independiente, pero sus resultados se acercaban más a las modalidades tradicionales, que a las nuevas tendencias, que recién aparecerían y muy bien delineadas con el TPV (Teatro Popular de Vanguardia), fundado por el argentino Oscar Wespel, Antonio Pecci, Rudy Torga, Erenia Lopez, Humberto Gulino, Ramón del Río y otros jóvenes, algunos de los cuales se rebelaron contra la enseñanza que se impartía en la Escuela Municipal de Arte Escénico. Con la formación del TPV, se inició un nuevo grupo y una nueva manera de hacerteatro a través de Talleres Teatrales, pues Wespel introdujo en Paraguay no solo la filosofía del Teatro Independiente, sino también nuevas técnicas y caminos para la investigación y la creación colectiva.

A su partida, el grupo continuó con su labor logrando imponer el Teatro de Cámara y espectáculos basados en adaptaciones y collage de fragmentos poéticos enlazados con textos originales, producto de creación colectiva, con los que se presentaron en centros estudiantiles principalmente, generando inusitado interés en el sector juvenil. En ese retorno a aquellos intentos dramáticos que décadas atrás se popularizaran con el nombre de Veladas, nuestro teatro independiente halló un rico antecedente para su consolidación, aunque esta vez, apoyado en sólido marco teórico, en el que no estuvo ausente la teoría brechtiana proveniente también de la Argentina.
A pesar de que el TPV incorporó con éxito la técnica del distanciamiento, en Historias para ser contadas de Dragún y en Ñandejara Rekove, adaptación de la vida de Jesucristo al medio campesino en versión bilingüe castellano-guaraní, el grupo no se decidía a emprender el montaje de obras de Brecht pues, según señala Pecci, No creíamos tener la acumulación teórica necesaria para comprender su estética teatral, ni la solvencia actoral requerida. De todos modos, la labor que realizamos por esos años, en un país dominado por un autócrata admirador de Hitler, estuvo impregnada por la actitud crítica hacia el arte y la realidad social establecida por Brecht. Sus poemas publicados en periódicos estudiantiles, motivaron la reacción de la Policía en los centros universitarios buscando al autor de esos versos impertinentes. Aun en esos años oscuros, Brecth no pasó desapercibido en Paraguay. Y gran parte del mérito es de quienes como Enrique Buenaventura, Omar Graso, María Escudero y Marcelino Duffau, nos estimularon en su conocimiento.

El TPV alcanzó la meta soñada por todo grupo teatral en aquel entonces al estrenar la Doña Rositala Soltera de García Lorca con dirección de Rudy Torga en el Teatro Municipal. Pero fue éste un logro de corto alcance, ya que la rebelión de estos jóvenes trascendía del campo artístico al de la política, lo que desembocó en persecuciones personales e imposibilidad de acceso a los centros artísticos oficiales. Y a la búsqueda de nuevas tendencias, se sumó la de nuevos espacios para la representación, hallando eco favorable en Centros Culturales Binacionales, colegios, universidades y clubes.

El Centro Cultural Paraguayo Americano, la Alianza Francesa, la Misión Cultural Brasileña, el Instituto de Cooperación Cultural de la Argentina y el Centro Cultural Español Juan de Salazar, al albergar a estos grupos, no sólo cumplieron con su función cultural sino que se convirtieron en auténticos bolsones de la resistencia artística paraguaya.

Hoy todos ellos cuentan con salas teatrales, pero hasta 1980, los pretendidos teatros eran salones multiuso para el desarrollo de actividades sociales y estudiantiles, carentes de recursos técnicos. Todo había que inventarlo o fabricarlo y todos tenían que hacer todo para alcanzar el codiciado premio de $H A C E R$ TEATRO. 
Cabe destacar que los teatros privados, por razones de índole comercial, habían ido desapareciendo para dar paso a las salas de exhibición cinematográfica y el Teatro Municipal, considerado como el primer y, también único, coliseo del país, por decisión gubernamental, cerró sus puertas a las manifestaciones de las artes escénicas, para albergar durante 1967 a la Convención Nacional Constituyente, situación que redundó en perjuicio de las compañías que aún gozaban de las ventajas de realizar temporadas en su escenario. Con su reapertura recrudeció la represión y al final de esta década, en la que el más tímido intento vanguardista era confundido con subversión, el Teatro Municipal se convirtió en coto cerrado de la dictadura, lo que determinó a varias compañías de larga trayectoria a unirse a las filas del Teatro Independiente.

Héctor de los Ríos, maestro de actores y director de memorables puestas, fue el primero en retirarse del Municipal en actitud de protesta por el rigor de la censura y el sectarismo de tinte político en el manejo de fechas. Pero además de ese escenario, abandonó también el llamado teatro de repertorio y el rótulo de Compañía Teatral con el se inscribían los elencos de la época, para fundar un grupo itinerante que bajo la modalidad del Café-Concert, no sólo recorrió los citados centros culturales, sino que creó, adaptó y ganó nuevos espacios para la representación.

Piezas breves, monólogos de Ionesco, Cocteau, Luis Matilla, García Lorca y fragmentos de la rica narrativa local y latinoamericana, entremezclados con música en vivo y poesía de los poetas prohibidos, Roa Bastos, Bareiro Saguier y Elvio Romero se constituyeron en el plato fuerte de estos menús artísticos y nuevamente la oralidad fue protagonista de la preservación y difusión de la obra de autores exiliados, a la que poco a poco irían incorporándose sketchs y piezas breves producto de la creación colectiva o de surgentes autores.

\section{$1970-1980$}

Significativos hechos marcan el inicio de esta década de consolidación de las nuevas tendencias escénicas y estos se relacionan con la mediterraneidad del Paraguay, no solo en el sentido geográfico sino en el de la trascenden- cia de sus manifestaciones al plano internacional.

Al inédito antecedente de la participación paraguaya de un grupo universitario dirigido por Hugo Herrera y encabezado por Erenia López en el Festival de Manizales, sucede la del TPV que acude a otra versión del mismo festival con Un Puñado de

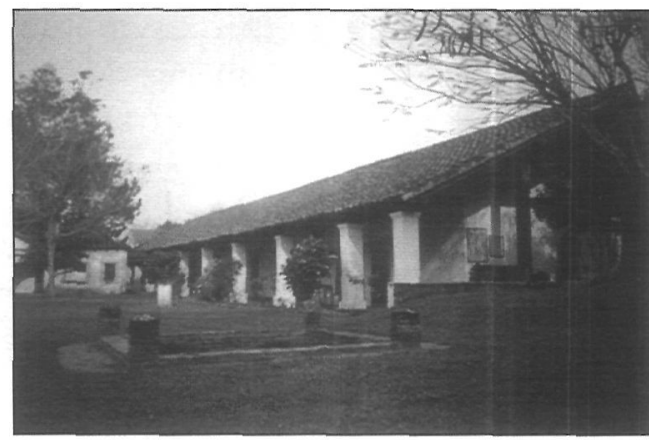

Casa colonial. (Foto: Mar Langa).
Tierra, montaje que basaba su acción dramática en el poema de Herib Campos Cervera del mismo nombre.

Y en esa cita obligada de la vanguardia teatral latinoamericana, sus componentes establecieron lazos con grupos y artistas del continente, muchos de los cuales, interesados en nuestro proceso, vinieron al Paraguay a dictar talleres, cursos y a colaborar con puestas escénicas, iniciándose así una era de intercambios e integración en el proceso teatral a nivel continental.

A consecuencia del éxito y proyección de su labor el 'TPV se desdobla. Rudy Torga funda el Teatro Estudio Libre (TEL) centrando su interés en el desplazamiento hacia barrios marginales e interior del país y Antonio Pecci y Erenia López prosiguen su labor al frente del TPV, en centros urbanos y universitarios.

El TEL inició actividades en el Centro Cultural Paraguayo Americano con Barranca Abajo de Florencio Sánchez. Poco después se instaló, en carácter permanente, en la Misión de la Amistad, entidad de asistencia social que le proporcionó, una pequeña sala con un modesto escenario para realizar representaciones y talleres. Esto significó la inserción del grupo en un barrio de características populares y la posibilidad de renovación con jóvenes de esa extracción que no habían sido, hasta el momento, protagonistas, ni público, del hecho teatral. Esta incorporación se tradujo en el surgimiento de actores, músicos, escenógrafos y técnicos y en una serie de montajes, en su mayoría en guaraní, que emprendió giras por áreas suburbanas y rurales.

$\mathrm{El}$ intento del actor argentino Ángel Moglia y del empresario e intelectual Adolfo Ferreiro de dotar a Asunción de una sala destinada a las manifestaciones del teatro independiente, fue abortado por la policía que
Dos décadas de teatro

independiente en Paraguay EDDA DE LOS RÍOS 
clausuró el Teatro Cero el día que debía inaugurarse con el estreno de Rómulo Magno de Durrenmatt e «invitó» a su director Moglia, a abandonar el país.

En 1971 nace el grupo más polémico de todos los tiempos, Tiempoovillo. El terreno estaba preparado, pues todo lo que quedaba afuera del Teatro Independiente, olía a vejez y anquilosamiento. El teatro popular se enquistó en desgastados esquemas y las puestas de las compañías de repertorio universal eran, aunque correctas, de temática intrascendente enfundadas en envejecidas y caducas formas. Los jóvenes exigían mayor osadía pero, hasta el momento, nombres como el de Grotowsky eran practicamente desconocidos.

Sorpresivamente, un grupo de estudiantes de arquitectura, encabezado por Agustín Nuñez y Ricardo Migliorisi, irrumpió con fuerza renovadora, maravillando a unos, desconcertando a otros e indignando a los más. ¿Qué significado podía dársele a la pretendida acción teatral de unos jóvenes que semidesnudos, corrían de un extremo a otro de la sala, gesticulando mucho, hablando poco y desafiando hasta la agresión al inocente espectador?

A pesar de éste y otros planteamientos similares, el grupo se impuso, y las propuestas grotowskianas introducidas por Nuñez luego de un periodo de estudio y contacto con figuras de la talla de Augusto Boal en el Brasil, acabaron siendo aceptadas por ese sector reacio al público y a la crítica que rechazaba todo intento que se apartara de lo convencional.

La ruptura del concepto tradicional del escenario y de las barreras físicas entre actores y público, la búsqueda de un espacio dedicado al ritual y la dosis de improvisación intercalada en la bien analizada y planteada estructura que, en principio, escandalizaran, fueron justamente aliciente y atractivo para la formación de nuevos grupos que como Ensamble y Laboratorio dirigidos por el argentino Victor de los Solares y Mauricio Schwarsman, Gloria Muñoz y Carlos Cristaldo respectivamente, transitaran por el camino despejado por Tiempoovillo.

La proliferación de grupos se extendió al interior del país, y a pesar de las circunstancias políticas y económicas desfavorables, se logró inaugurar una Muestra Paraguaya de Teatro que se repitió en años posteriores con la par- ticipación de grupos de todo el país y figuras de renombre internacional, tales como Omar Grasso, Enrique Buenaventura, María Escudero, Marcelino Duffau y Hermilho Borba Filho, quienes, sin ningún tipo de exigencias, impartieron seminarios y participaron en mesas de diálogo y reflexión e intercambios de experiencias.

Lamentablemente este movimiento de alcances insospechados se diluyó en el agitado mar de las convulsiones políticas. Integrantes de algunos grupos fueron a parar a la cárcel, al exilio o simplemente abandonaron «por peligrosa», la actividad teatral.

Tiempoovillo partió para una larga gira que se inició en los célebres Festivales de Manizales y Caracas y prosiguió en Centroamérica en dónde el grupo se disolvió, por dispersión de sus componentes, algunos de los cuales se radicaron en diferentes países. Otros, como Raquel Rojas y Antonio Carmona, regresaron a Paraguay y fundaron el célebre grupo Aty $\tilde{N} e e$, al que se incorporó el dramaturgo más representativo del momento, Alcibiades González Delvalle.

Aty Neé se planteó una relación enriquecedora en su trabajo realizando prolongadas pasantías en localidades del interior, con el propósito no solo de llevar teatro desde la capital, sino de nutrirse de la temática y las formas que la tradición popular conservaba celosamente. Así se recuperaron verdaderos tesoros de la cultura popular, como los cuentos picarescos de Perú-Rimá (Pedro de Urdimales), la Velada, como forma conjunta de expresión (poesía, teatro y música) y aspectos de la problemática social y económica de los campesinos, reflejadas en obras como $\mathrm{El} \mathrm{Al-}$ macén y Mandiyity (Algodonal), elaboradas a partir de la relación de los dramaturgos González Delvalle y Antonio Carmona con campesinos con los que convivieron durante el periodo de giras. Estos contactos también se tradujeron en constitución de grupos teatrales locales que expresaban, historias transmitidas generacionalmente o experiencias propias.

Es imposible citar a todos los grupos que en los años 70 surgieron, murieron y se regeneraron. Por ello destacamos a los considerados grupos-madre de los demás y que, en penosas giras por caminos a los que ni siquiera el asfalto había llegado, hicieron posible el arribo del teatro. 
El sueño de un local estable para los independientes se concretó en 1977, cuando Héctor de los Ríos instaló La Farándula en la histórica estación del ferrocarril. También allí tuvo que hacerse todo para que el viejo $y$ abandonado salón del piso superior se asemejara a una sala teatral que durante sus tres años de vida brindó espacio a todos los grupos que lo solicitaron y en muchas de las obras presentadas, cobraron vida personajes de la clase media paraguaya en agudas sátiras de gran repercusión, algunas producto de creación colectiva y otras originales de Alcibiades González Delvalle, Antonio Carmona y Edda de los Ríos.

La Farándula también inició una serie de intercambios con directores y elencos rioplatenses y en sus instalaciones destacaron, el Mes del Teatro Uruguayo, con representaciones de unipersonales a cargo de las actrices Estela Medina y Estela Castro y el elenco del Teatro Circular de Montevideo, La Lección de Anatomía con el célebre grupo argentino dirigido por Carlos Matus y la contratación de Mario Morgan para la puesta de Sara Bernhardt de John Murrel, con actores locales.

A pesar del hostigamiento sistemático por parte de las autoridades policiales, todo parecía andar sobre ruedas cuando las autoridades del ferrocarril recibieron una «orden superior» que concluyó con la vida teatral en sus instalaciones, y aunque La Farándula continuó su labor, al igual que otros grupos, el movimiento independiente fue cambiando de rumbos.

Puede aseverarse que la aparición del Teatro Callejero, en el que destacan hasta la fecha los directores Teresa González Meyer y Miguel Gómez y como indiscutible autor, Moncho Azuaga, cierra con brillo, a principios de los 80, el capítulo que comprende estos 20 años de historia del Teatro Independiente en Paraguay. 


\section{Sonja M. Steckbauer}

Se doctoró en la Universidad de Salzburgo, Austria (1990); estudió en la Universidad Católica del Perú en Lima y trabajó en la Universidad de Guadalajara, México; es profesora honoraria de la Universidad Ricardo Palma de Lima, Perú (1994); actualmente trabaja en la Universidad Católica de Eichstätt, Alemania. Su principal área de investigación es la literatura latinoamericana del siglo veinte. En los últimos años ha publicado varios artículos y reseñas sobre la literatura paraguaya actual y acaba de presentar su trabajo de postdoctorado en alemán sobre el tema: Isla sin mar. Prosa paraguaya de 1980 hasta 2000. Publicaciones más recientes: La novela latinoamericana entre historia y utopía (ed., 1999), Perú: zeducación bilingüe en un pais plurilingüe (2000), Theater in Argentinien (coord., 2002).

\section{RAQUEL SAGUIER: FICCIÓN AUTORREFLEXIVA Y SOCIOCRÍTICA EN BUSCA DEL AMOR}

\author{
SONJA M. STECKBAUER
}

1

Actualmente, Raquel Saguier estó escribiendo una nueva novela que se titulará El amor de mis amores.

2

Sobre la denuncia e ironía en las novelas de Raquel Saguier, véase el artículo de Gabriella Dionisi 2002.
Raquel Saguier: ficción autorreflexiva y sociocrítica en busca del amor SONJA M. STECKBAUER
Raquel Saguier es, sin duda, una de las más innovadoras narradoras paraguayas actuales. Ha publicado hasta ahora cuatro novelas: $L a$ niña que perdi en el circo, 1987, traducida al francés y al portugués; La vera bistoria de $P u$ rificación, 1989; Esta zanja está ocupada, 1994, galardonada con varios premios, entre ellos el Premio Lector; y finalmente La posta del placer (1999), galardonada con el Premio Municipal de Literatura del Paraguay ${ }^{1}$.

A pesar de que estas cuatro novelas se diferencian tanto en lo que se refiere al estilo como al contenido, tienen algunos rasgos en común, siendo el más destacado una fuerte crítica de la sociedad paraguaya, en especial de la perteneciente a la clase media y alta en Asunción. Esta crítica, que en su totalidad llega a ser denuncia ${ }^{2}$, siempre se encuentra en el segundo plano de la narración - que es de una historia personal en dos casos y de un crimen en los otros dos-, y nunca es directa sino irónica y da lugar a la risa $o$, por lo menos, a una cierta sonrisa satisfecha de reencontrarse a sí mismo o a gente conocida. A continuación, se destacarán estos aspectos de la narrativa de Raquel Saguier, poniendo de esta manera mayor énfasis en sus dos últimas novelas, sin dejar de lado las primeras.

\section{ESTA ZANJA ESTÁ OCUPADA (1994)}

En un primer nivel, se trata de una novela policíaca que se concentra en aclarar el asesinato de Onofre Quintreros quien - en la primera página de la novela - se halla muerto en una zanja de la ciudad de Asunción. Al aden- trarse más en la novela, el lector descubre que lo esencial no es encontrar a esa persona, sino que se trata de una denuncia de la sociedad machista de la clase media alta asuncena, en la cual el ser y el parecer difieren completamente el uno del otro. Todas las mujeres que aparecen a lo largo de la novela y que estuvieron en contacto con Onofre lo odiaban lo suficiente como para haberlo matado. Son su esposa Sofía Bernal, que se casó con él para no quedarse solterona; Lumina Santos, que mantuvo con él una relación sexual durante varios años por razones económicas; $y$ finalmente, Leonor, para quien Onofre representó el primer amor y a la vez la máxima decepción. Lo que caracteriza a esta novela es que el lector conocerá a Onofre Quintreros desde varias perspectivas que dan, por tanto, luz a varias facetas tanto de su vida como de la sociedad capitalina. A la vez, esta novela se enfrenta el machismo de manera humorística y a veces cínica.

Con el motivo de la resolución del asesinato, la autora desmitifica paso a paso la vida de este hombre, empezando con su propio pasado: fue criado en un ambiente muy pobre por su madre adoptiva Gumersinda a la que Onofre olvidó inmediatamente después de hacerse una mejor vida en Asunción; vivió en la hacienda del inmigrante alemán Don Walter a cuya hija Leonor violó; por último, se casó con la mujer más rica que pudo alcanzar y la engañó tanto como más tarde a su socio $\mathrm{Re}^{-}$ caredo Anodino Flores. En total, no fue un hombre admirable sino más bien una persona deplorable: 
¿Quién lo hubiera sospechado, no es cierto?, que Onofre Quintreros no fuera en realidad el que todo el mundo creía, sino nada más y nada menos que un cabal almacén de complejos, con varios gramos de cobardias, muchas docenas de miedos, y un estante repleto de las dudas que cada uno prefiera. Por lo tanto, sí señor, un firme candidato a la siquiatría. (Saguier 1994, 45)

Esta descripción del pasado del protagonista lleva a Gabriella Dionisi a la comparación de Onofre con Artemio de La muerte de Artemio Cruz de Carlos Fuentes (cf. Dionisi 2002), aunque habrá que añadir que, a diferencia de este último, aquí la simpatía del lector se va alejando más y más del protagonista hasta llegar a un menosprecio total. Al final de la novela se vuelve al principio, es decir, Onofre termina su vida donde la empezó: en una zanja de un barrio popular de la ciudad, encontrado por un vendedor ambulante días después de su muerte, y olvidado rápidamente y con ganas por todos.

Toda la novela está escrita en tercera persona por un narrador omnisciente. Sin embargo, no solamente la perspectiva sino también el lenguaje de la narración cambian según lo narrado, y dan de esta manera mucha vivacidad al relato. Tal es así que, cuando se narra el acto sexual entre los esposos Sofía y Onofre, se utiliza un lenguaje tan neutro y frío como la personalidad de Sofía; mientras que en las horas amorosas de Onofre con Lumina el lenguaje es vivaz y divertido, tal como es ella, un lenguage salpicado de dichos populares: «[...] porque la que empieza dando un beso acaba por ceder también el queso.» (Saguier 1994, 62)

La siguiente cita, tomada del entierro de Onofre Quintreros, es una prueba más del estilo refinado que domina Raquel Saguier. Se trata de la descripción de Sofía Bernal por un narrador omnisciente impersonal que permite a la vez traslucir la observación por parte de los espectadores y leer los pensamientos de la esposa; después de un salto temporal se llega a la descripción que dará la viuda para explicarle, días después, al comisario su comportamiento en el entierro, y la escena concluye con una aclaración dirigida al lector. Vale la pena citar in extenso para dar una prueba de la riqueza narrativa de Raquel Saguier:

Se armó un ligero barullo a continuación porque ahí estaba nada más y nada menos que la flamante viu- da, Sofía Bernal de Quintreros, dentro de una dignidad severamente enlutada: negro el trajecito de dos piezas, negros los zapatos, negra la cartera, renegrido el peinado, y llorando a lágrima viva todas las infidelidades que le adornaban la testa, $y$ de las que prefiero no hablar, señor comisario, al menos por el momento.

Después, de acuerdo con la discreción que le habían inculcado desde niña, se interrumpió bruscamente, enterrando la cara entre los vapores gálicos de un menudo pañuelito, no para reanudar el llanto, como lo supusieron todos, sino para sofocar en privado su primer grito de independencia. (Saguier 1994, 141)

Esta combinación de diversas técnicas narrativas, en especial el cambio de perspectivas y de tiempos, convierte la solución del crimen en una interesante aventura para el lector en la búsqueda de un culpable - a quien mientras tanto ya no se le echa la culpa sino nomás a la víctima.

El final es tan sorprendente como interesante: Leonor no ha podido olvidar ni superar psíquicamente la violación por parte de Onofre cuando era una niña de 12 años, y vive, como consecuencia, en un manicomio en Asunción. Para ella, la única forma de superar este dolor, es inventar la muerte del usurpador Onofre, aunque sea en ficción. Escribe una novela, la que el lector tiene en sus manos. En las últimas páginas se van intercalando cada vez más realidad ficticia y metarreflexión literaria hasta llegar a confundirse. Leonor se escapa del manicomio, ve a Onofre asesinado en la zanja y no sabe si es ella misma la que lo ha matado o la que lo ha inventado, e incluso llega a dudar de su propia existencia:

Porque entre tantas y tan variadas conjeturas cabe también la de que Onofre no pase de ser pura fabulación mía, [...] que hasta se me quita el sueño pensando que yo no soy yo, sino un horrible simulacro, un mero personaje de ficción vaya a saber por quién inventado y, sobre todo, con qué fin. (Saguier 1994, 187)

La invención y la ficción como necesidad para poder enfrentarse a la vida diaria y a sus obstáculos. Parece ser un camino por el que anda no solamente lá autora - del crimen y de la novela- ficticia Leonor en Esta zanja está
Raquel Saguier: ficción autorreflexiva y sociocrítica en busca del amor SONJA M. STECKBAUER 


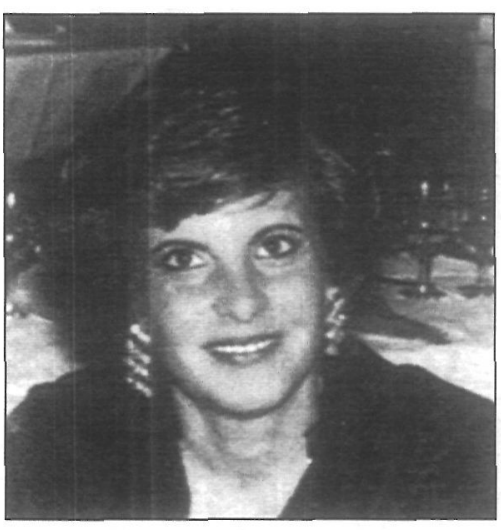

Raquel Saguier. ocupada, sino que toman también las protagonistas de otras novelas de Raquel Saguier, un camino buscado y encontrado en la ficción por la propia novelista. Ésta última admitió en una entrevista realizada en marzo de 2000 en Toulouse, Francia, que pasaba muchas horas en su casa por razones personales, y que su salida era la escritura.

A continuación, se ofrece una retrospectiva hacia las primeras dos novelas de la autora, mucho más autobiográficas y de una técnica literaria más simple, pero no menos elaborada, antes de pasar a la última, La posta del placer, que más bien hace pareja con la que se acaba de presentar.

\section{LA NIÑA QUE PERDÍ EN EL CIRCO (1987)}

La primera novela publicada de Raquel Saguier es marcadamente autobiográfica. Describe los pensamientos de una niña que se mira en un espejo o en una fotografía - la portada de la primera edición muestra una fotografía de la misma autora cuando era joven - y reflexiona sobre su propio pasado. Es una retrospectiva en primera persona y narrada en el lenguaje simple e inocente de esta niña, que deja vislumbrar un pasado triste y solitario. La niña se crió con sus dos tías solteronas, extremadamente conservadoras y conformistas, quienes reaparecerán en la siguiente novela de la autora, La vera bistoria de Purificación y que en algunos aspectos hacen pensar en Doña Ángela de la novela La Babosa de Gabriel Casaccia. La niña hace el camino inverso de su historia personal, regresa paso a paso por los tristes corredores de la casa donde pasó su niñez a fin de llegar al principio $y$, en último lugar, a fin de encontrarse a sí misma. En el último capítulo, logra este objetivo y se produce el reencuentro entre la mujer adulta y la niña, quien es a su vez su propio pasado, puesto que la escritura le ha permitido descubrirse a sí misma. $\mathrm{O}$, en palabras de José Vicente Peiró, se produce el «desdoblamiento» de ambas. (Cf. Peiró 2001, cap. 2.2.3.)

Pero esta vez no nací de mi madre sino de las entrañas de un libro. Su primer libro. Allí encontre [sic] mis raíces, mi alimento, mi pequeña ración de vida. Ella tu- vo que escribirlo, tuvo que abrirse, pujar desde su oscuridad para que yo saliera a la luz. (Saguier 1987, 140)

Tal como en Esta zanja está ocupada, ya en La niña que perdí en el circo la escritura cumple un rol terapeútico. Así como allá Leonor, aquí es Raquel - autora/protagonista/narradora en primera persona - quien necesita escribir en la oscuridad para aclarar las manchas oscuras de su propio pasado. En los dos casos es una terapia fructífera y una fuerte crítica que en La niña que perdí en el circo nunca llega a ser irónica o sarcástica - al orden patriarcal tradicional e impuesto, que principalmente se caracteriza por la educación marcada por la diferencia de sexos que ha recibido esta niña y que siguen recibiendo muchas otras. Ésta también será tema de la siguiente novela de la autora, La vera historia de Purificación, con la diferencia de que la protagonista demostrará una incipiente rebelión.

\section{LA VERA HISTORIA DE PURIFICA- CIÓN (1989)}

Esta novela describe la vida de una mujer joven e infeliz, Purificación, que asume el papel esperado por su esposo y por la sociedad hasta que un día conoce a un joven pianista de quien se enamora. Nuevamente el tema fundamental de la novela es «el duro oficio de ser mujer en una sociedad patriarcal, inficionada de hipocresía y autoritarismo», tal como lo anuncia Osvaldo González Real en el «Prológo» (Saguier 1989, 10). Pero a diferencia de la protagonista de la primera novela de Raquel Saguier anteriormente descrita, en La vera bistoria de Purificación la mujer logra liberarse de las cadenas impuestas por la sociedad mediante el verdadero amor y la música, las dos fuerzas que comparte con su amante Fidel. Mientras que para la niña de La niña que perdí en el circo, el piano representaba el sueño anhelado, para Purificación éste constituye el cumplimiento de sus deseos.

Al final de la novela, la narradora en primera persona no sabe si el acto de amor con Fidel bajo la Novena de Beethoven fue verdad o imaginación, pero no le importa. Lo importante para ella es que por primera vez se siente libre y feliz:

Y si por casualidad alguien insinuara la sospecha de lo que lo mío ha sido un sueño, o acaso menos que
Raquel Saguier: ficción autorreflexiva y sociocrítica en busca del amor SONJA M. STECKBAUER 
eso - [...]-, a ese alguien yo le diría que sí, que es cierto. Es quizá ínfimo lo que de allá traemos, pero a la vez algo precioso. Sobre todo si la cara que soñamos corresponde a la que estamos viendo fuera de sueño. (Saguier 1989, 173s.)

Todas las protagonistas centrales de las novelas de Raquel Saguier hasta aquí tratadas están en busca de ese algo, que podría resumirse con la palabra «amor», y todas se rebelan contra las estructuras sociales existentes en una sociedad patriarcal, con diferente éxito en ambos aspectos. Mientras que la niña de la primera novela de Raquel Saguier ni siquiera recibe el piano - la metáfora para la libertad-, la mujer de la segunda novela aprende a tocarlo y a gozarlo. Mientras que Purificación experimenta el verdadero amor, por lo menos en el sueño, ninguna de las tres mujeres que tienen una relación sexual con Onofre Quintreros - Leonor, Lumina Santos y Sofía Bernal - aman verdaderamente o son amadas. Sin embargo, dos de ellas son capaces de sacar el máximo provecho de su relación con el hombre, ya sea económica o socialmente. La novelística de Raquel Saguier se caracteriza, por tanto, no sólo por la denuncia de la sociedad machista sino más bien por la denuncia de las relaciones amorosas de conveniencia.

Ella [Lumina] responde con valentía al machismo del protagonista, quien la ve como un negocio, pero que se convierte en una empresa frustrada al final porque se revela la superioridad de la mujer sobre el hombre que se complace de su virilidad y desprecia la inteligencia femenina. (Peiró 2000, cap. 2.2.3.)

Lo dicho no implica que las novelas de Raquel Saguier dejen un sabor amargo después de la lectura, sino que más bien al contrario, dan lugar a la esperanza: la liberación de «la niña» es retrospectiva y ficticia, la liberación de la esposa Purificación es onírica y musical, $y$, finalmente, la liberación de las tres mujeres alrededor de Onofre es real y a la vez inventada. En suma, las mujeres logran liberarse de las cadenas impuestas por la sociedad y permiten una visión optimista hacia el futuro.

En la última novela de Raquel Saguier se pone de relieve otra vertiente del amor, el amor pagado, el amor en un prostíbulo, que también tiene su reglamento y pone en tela de juicio al que lo traspasa.

\section{LA POSTA DEL PLACER (1999)}

Nuevamente se trata de una novela policíaca en la que la narración gira alrededor de la resolución de un «crimen», sólo que no es un crimen en el sentido estricto de la palabra: Nicasio Estigarribia suele ir a un burdel y una vez allí, se retira a un cuarto sólo, sin chica, lo único que lleva consigo es un pequeño maletín. Se cuentan seis versiones diferentes del supuesto crimen - «Versión inmediatamente anterior a la versión de la muñeca inflable», "Versión tumultuosa de la muñeca inflable», «Versión del testamento ológrafo», «Versión del autoflagelamiento», «Versión del General Celestino Robles» y finalmente, la «Versión durante la cual se hace un repentino silencio para que ' $\mathrm{La}$ posta del placer' cuente su historia» - a lo largo de las cuales se revela no solamente la vida de Nicasio sino también la de los otros huéspedes de «La posta del placer» $y$, en consecuencia, la de cierta parte de la sociedad asuncena.

Esta novela se puede inscribir en la lista de novelas latinoamericanas donde la narración está ubicada en un prostíbulo, tal como La casa verde de Mario Vargas Llosa o Las muertas de Jorge Ibargüengoitia, para sólo mencionar los dos ejemplos más conocidos. Lo que relaciona la novela de Raquel Saguier con la última mencionada es que en las dos se trata de aclarar un crimen cometido en un prostíbulo - en la novela de Ibargüengoitia se mueren en total seis prostitutas-, pero a diferencia de ésta y otras novelas policíacas, en La posta del placer el crimen sólo existe en la mente de la gente observadora. Es exactamente esa gente hacia donde se dirige la crítica.

El tono de la novela es, en su totalidad, extremadamente irónico, como se nota ya desde las primeras páginas, cuando la dueña del local explica a dos nuevos clientes el reglamento del lugar. Con la misma disciplina de un Pantaleón Pantoja de la novela Pantaleón y las visitadoras de Mario Vargas Llosa, Doña Coca ha impuesto parquímetros sexuales a la entrada de cada cuarto, «[...] creados a la imagen y semejanza de los parquímetros callejeros, la diferencia residía en que los suyos se hallaban enteramente pintados de rojo.» (Saguier 1999,

\section{Raquel Saguier}

La POSTA del PLACER

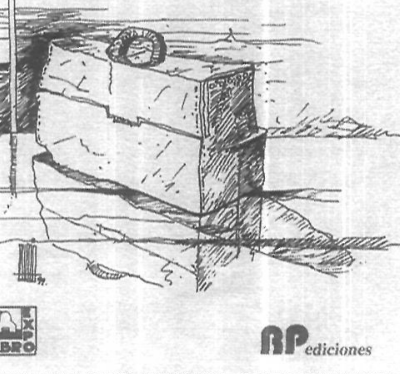

nestes

iif ediciones

del Placer. Portada.
Raquel Saguier: ficción autorreflexiva y sociocrítica en busca del amor SONJA M. STECKBAUER 

en estas dos novelas paraguayas, véase el artículo de María del Carmen Pompa Quiroz 1989.
24) A diferencia de las prostitutas de otras novelas paraguayas, como Salu'i en Hijo de hombre de Augusto Roa Bastos o Cipriana Romero en La llaga de Gabriel Casaccia, las dos mujeres que entran en la prostitución como última forma de supervivencia, Doña Coca no es para nada digna de compasión ${ }^{3}$. Y tampoco se le acusa por el negocio que mantiene sino que más bien se destaca la efectividad con la que atrae a sus futuros clientes:

Luego, [...] armó un sigiloso paquete que con toda discreción hizo llegar a los representantes de ambas Cámaras, a los del Cuerpo Diplomático, al sacrificado Cuerpo de Bomberos, y en general a todos los cuerpos que estuvieron listos a disfrutar 40 celestiales minutos en completo recocijo. (Saguier 1999, 189)

En La posta del placer el verdadero amor no existe; por tanto, el amor que se ofrece en «La posta del placer» es una excelente recompensa. Al final, al esclarecerse la razón de las asiduas visitas de Nicasio - en su cuarto se encuentran algunos poemas escritos por él así como La Divina Comedia -, queda claro que para él la búsqueda del amor lo lleva a su mejor sustitución que es la literatura.

Una vez más en la novelística de Raquel Saguier, el arte - en especial la literatura y la música - le da al hombre lo que no ha encontrado en la vida real: felicidad, amor, libertad. Aquí se halla probablemente el mensaje central de la obra de esta destacada narradora.

Con sus últimas dos novelas Raquel Saguier se presenta como escritora postmoderna que domina perfectamente los parámetros que impone la nueva novelística. Confluyen en ellas heteroglosia con cambio de perspectivas, ironía con parodia, intertextualidad con metareflexión literaria. A pesar de tratarse de obras elaboradas en cuanto a sus técnicas narrativas permiten una lectura fácil y divertida.
No obstante, sea cual sea la trama de la novela, después de la lectura de una de las novelas de Raquel Saguier -y más aún de las cuatro-, se puede reconocer claramente la preocupación principal de la autora: descubrir las esferas oscuras de la sociedad desde el sentimiento. Esta sensibilidad de la autora le da veracidad a su obra.

\section{BIBLIOGRAFÍA}

DIONISI, Gabriella, «Denuncia e ironía en las novelas de Raquel Saguier», HISPANORAMA, 98 (2002). Págs. 27-30.

PEIRÓ, José Vicente, Literatura y sociedad: la narrativa paraguaya actual (1980-1995), Madrid, Universidad Nacional de Educación a Distancia, tesis de doctorado, 2001. En Biblioteca Virtual Miguel de Cervantes (www.cervantesvirtual.com).

POMPA QUIROZ, María del Carmen, «Imagen de la prostituta en dos novelas paraguayas», Revista Enfoques de Mujer, 4 (1989), págs. 14-17.

SAGUIER, Raquel, La niña que perdí en el circo, Asunción, RP ediciones, 1987. [2 $2^{\mathrm{a}} \mathrm{ed}$. 1991; francés: La petite fille que j'ai perdue au cirque, Paris, Éditions du Griot, 1992; portugués: A menina que perdi no circo, Porto Alegre, Mercado Aberto, 1993; 13 reediciones].

SAGUIER, Raquel, La vera historia de Purificación, Asunción, RP ediciones, 1989.

SAGUIER, Raquel, Esta zanja está ocupada, Asunción, RP ediciones, 1994.

SAGUIER, Raquel, La posta del placer, Asunción/Buenos Aires, RP ediciones/Expolibro, 1999.

STECKBAUER, Sonja M., Insel obne Meer. Prosa Paraguays von 1980 bis 2000, Eichstätt, Universidad Católica de Eichstätt, tesis de postdoctorado, 2001. 


\title{
ECOS LORQUIANOS EN LA MEMORIA POÉtica del paraguay: \\ JOSEFINA PLA, AUGUSTO ROA BASTOS Y HÉRIB CAMPOS CERVERA
}

\author{
PACO TOVAR
}

Nunca estuvo Federico García Lorca en Paraguay; sí llegó a orillas del Plata y deslumbró también a ciertos poetas del mediterráneo paraguayo, dejando en la zona un rumor lírico, tantas veces manejado con fuerza épica, moldeado en imágenes sonoras dispuestas a reclamar cómplices, no tahúres de salón amable o canallas desbocados. El reclamo lorquiano, derivado en ocasiones hacia el histrionismo, habría de estimular el sentido mágico de ciertas conciencias rioplatenses, ayudándoles en la aventura poética que apenas se iniciaba en Paraguay, todavía entretenido en balbuceos poéticos forjados en su propio caldo de cultivo.

\section{TILDES ANDALUZAS}

Resulta oportuno evocar la procedencia confesional del quehacer literario emprendido por Lorca, desplazando éste hacia los márgenes. Al mismo autor cuenta, con la ayuda de ilustraciones selectas, que la naturaleza del arte se descubre al compás de las voces, cuando son originales; al ritmo del artificio, cuidadosamente organizado con sinceridad; y sostenido por el duente, pulsado con rigurosa libertad, pero modulado por costumbre en las fronteras de un medio que tiende a recluirlo en atmósferas tabernarias, o emplearlo como objeto de estudio folclórico en laboratorios de iniciados.

No es un secreto que, en parte sustancial, esa dimensión artística descubre en Lorca querencias significativas por el cante jondo, de amplio espectro, perfiles andaluces y rasgos primitivos, apreciando menos, con ese registro, su pariente flamenco, de reciente sabor común, fórmula postiza y talante local. El primero esgrime en su favor trágicos mestizajes de rancia nobleza; el segundo utiliza las claves del anterior para construir nuevos destellos de ingenio en los mercados del compadreo. Aquél, de simple apariencia que no elude ornamentaciones, tañe, con gracia popular, firme emoción y pulso simbólico, los colores del espíritu, guardando memoria de los viejos tiempos; sus postizos armónicos emplean fáciles recursos para dibujar matices y trazar arabescos en piezas que recuerdan escenas costumbristas. Ambos pueden ser gitanos, pero de solera unos y dudoso calibre los demás, quizás porque los últimos sólo alcanzan formas definitivas en el XVIII.

Se da el nombre de cante jondo a un grupo de canciones andaluzas cuyo tiempo genuino y perfecto es la seguirilla gitana, de las que derivan otras canciones aún conservadas por el pueblo, como los polos, martinetes, carceleras y soleares. Las coplas llamadas malagueñas, granadinas, rondeñas, peteneras, etc., no pueden considerarse más que consecuencias de las antes citadas, y por tanto su arquitectura como por su ritmo difieren de las otras. Estas son las llamadas flamencas. ${ }^{1}$

Esta lección de música remite a las apreciaciones de Falla, un maestro para quién los sistemas musicales del cante jondo disponen

\section{Paco Tovar}

Catedrático de Literatura Hispanoamericana en la Úniversidad de Lleida. Es autor de libros sobre Augusto Roa Bastos (1987 y 1993), y de una visión múltiple de autores y problemas de la literatura hispanoamericana del siglo $\mathrm{XX}$ (Contrapunto, 2002). Ha publicado además numerosos artículos sobre vanguardias, Vicente Huidobro, Juan Carlos Onetti, Mario Monteforte, Alejo Carpentier, etc. Es miembro fundador de la Asociación Española de Estudios Literarios Hispanoamericanos y Secretario General de la misma desde 1992 hasta la actualidad.
1 Federico García Lorca, «El cante jondo», Obras Completas, Aguilar, Madrid, 1974, T. I. , pág. 971.
Ecos lorquianos en la memoria poética del Paraguay: Josefina Pla, Augusto Roa Bastos y Hérib Campos Cervera 


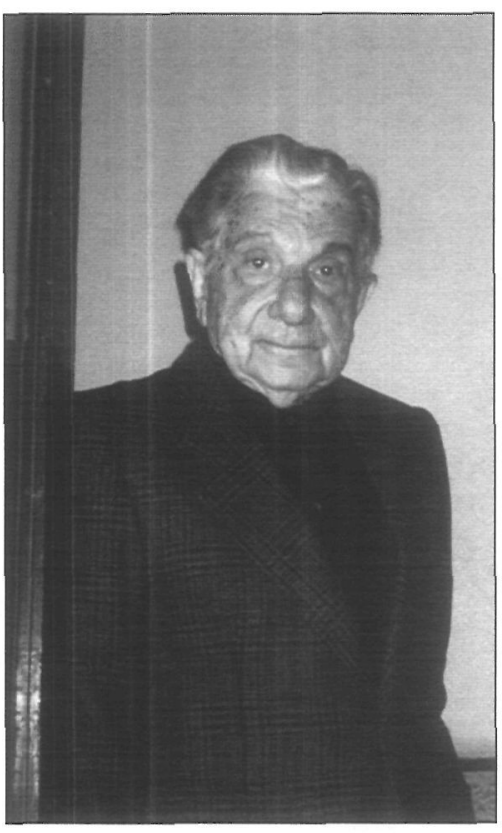

Augusto Roa Bastos (Foto: Mar Langa).

2

«El cante jondo», op. cit., pág. 975.

3

Ibidem, págs. 977 y 982.

4

«El cante jondo», op. cit., pág. 986.

Ecos lorquianos en la memoria poética del Paraguay:

Josefina Pla, Augusto Roa Bastos y Hérib Campos Cervera PACO TOVAR de un sólido pasado con origen en la India, escuchándose siempre con ellos

...una maravillosa ondulación bucal, que rompe las celdas sonoras de nuestra escala atemperada, que no cabe en el pentagrama rígido y frío de nuestra música actual, y abre en mil pétalos las flores herméticas de los semitonos.

El cante flamenco no procede por ondulación, sino por saltos; como en nuestra música tiene un ritmo seguro y nació cuando ya hacía siglos que Guido d'Arezzo había dado nombre a las notas.

[El cante jondo es], pues, un rarísimo ejemplar de canto primitivo, el más viejo de toda Europa, que lleva en sus notas la desnuda y escalofriante emoción de las primeras razas orientales. $^{2}$

Pero esa rancia procedencia del cante jondo no debe confundirse con una forma trasplantada; mejor entenderla como un injerto que permite asomarse a cierta coincidencia de orígenes y obedece a la acumulación de tantos hechos históricos con raíces en la tierra. Rara vez superan, por enharmónicos, la sexta escala, repitiendo con obsesión motivada una misma nota, siendo este un procedimiento acusado en ciertas fórmulas de encantamiento o antiguos recitativos que se identifican con los inicios del lenguaje.

Se puede afirmar definitivamente que el cante jondo, lo mismo que en los cantos del corazón de Asia, la gama musical es consecuencia directa de lo que podríamos llamar gama oral.

Son muchos los autores que llegan a suponer que la palabra y el canto fueron una misma cosa.

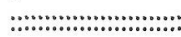

Vean ustedes, señores, la trascendencia que tiene el cante jondo [...]. Es hondo, verdaderamente hondo, más que todos los pozos y todos los mares que rodean el mundo, mucho más hondo que el corazón actual que lo crea y la voz que lo canta, porque es casi infininito. Viene de razas lejanas, atravesando el cementerio de los años y las frondas de los vientos marchitos. Viene del primer llanto y del primer beso. ${ }^{3}$

Reconocer en las palabras una filiación sonora conduce a desvelar la maravilla comprendida en sus poemas, no en los podados con las tijeras del romanticismo y postroman- ticismo, sino en los crecidos en árbol genési$\mathrm{co}$, donde se encuentran las infinitas gradaciones del Dolor y la Pena, puestas al servicio de la expresión pura y exacta. Esas coplas de original factura tienen un fondo común: el Amor y la Muerte..., pero un amor y una muerte vistos a través de la Sibila.

Transmisora potencial de los secretos, secreto ella misma, la hembra misteriosa continúa recibiendo preguntas sobre pregunta, guardando celosamente las soluciones de cualquier enigma; cuando más, los insinúa para vestir cantos que eluden recurrir al medio tono, detalle propio de la honda expersión andaluza, tan profunda y extrema que suele dirigir sus gritos a las estrellas o sembrar sus besos en el polvo rojizo de los caminos. Semejante a los trinos del ruiseñor sin ojos, los murmullos del cante jondo pertenecen a los ciegos, y por eso, tanto sus textos como sus melodias antiquísimas tienen su mejor escenario en la noche. Rodeadas de oscuridad y encerradas en sí mismas, esas formas sonoras son también las flechas de un formidable arquero azul cuya aljaba no se agota jamás. Tremendas visiones nocturnas de aguda punta y certero blanco, no son populares por carecer de autor conocido, restando así suspendidas en el vacío y lejos de la consciencia; pertenecen a las gentes comunes, porque ellas saben adaptarlas a su sensibilidad.

Los poetas que hacen cantares populares enturbian las claras linfas del verdadero corazón; y icómo se nota en las coplas el ritmo seguro y feo del hombre que sabe gramática! Se debe tomar del pueblo nada más que sus últimas esencias y algún que otro ritmo colorista, pero nunca imitar fielmente sus modulaciones inefables, porque no hacemos otra cosa que enturbisrlas. Sencillamente, por educación.

Los verdaderos poemas del cante jondo no son de nadie, están flotando en el viento como vilanos de oro y cada generación los viste de color distinto, para abandonarlos a las futuras.

Los verdaderos poemas del cante jondo están en sustancia sobre una veleta ideal que cambia de dirección con el aire del Tiempo.

Nacen porque sí, son un árbol más en el paisaje, una fuente más en la alameda. ${ }^{4}$

La mirada lorquiana se desplaza ya hacia la mujer, Pena con forma humana y línea definida; reconoce el panteísmo del hondo decir enharmónico, recogido en abanicos temáticos de carácter melancólico; y tiende a escuchar con 
atención las voces sentidas, que se ofrecen a cambio de nada y no admiten comparaciones; tampoco son cantos tratados con justicia...

...y vuelvo a insistir en la infamia que se comete con ellos, relegándolos al olvido o prostituyéndolos con la baja intención sensual o con la caricatura grotesca. Aunque esto ocurre exclusivamente en las ciudades porque afortunadamente para la virgen Poesía, y para los poetas, aún existen marineros que cantan sobre el mar, mujeres que duermen a sus niños a la sombra de las parras, pastores ariscos en las veredas de los montes; y echando leña al fuego, que no se ha apagado del todo, el aire apasionado de la poesía avivará las llamas y seguiran cantando las mujeres bajo las sombras de las parras, los pastores en sus agrias veredas y los marineros sobre el ritmo fecundo del mar. ${ }^{5}$

El gusto de Lorca por los aciertos sonoros del instrumento popular no desprecia la calidad del verdadero artificio poético. Ese imposible acuerdo deja de ser una paradoja cuando se entienden los juegos originales de otro maestro andaluz: Góngora, de superior envergadura y profunda dimensión.

Ángel de luz o espíritu de tinieblas, Góngora forma parte de un debate que pretende marcar las diferencias entre los poetas llamados populares o impropiamente nacionales, y los poetas llamados propiamente cultos o cortesanos, discusión liviana porque carece de motivos, aunque baste revisar la historia literaria española para confirmar el enfrentamiento y las maneras de argumentarlo, discusiones que habrá de resolver Lorca una vez localizado el necesario espacio para situar las coincidencias:

...quiero hacer constar que no creo en la eficacia de esta lucha ni creo en lo de poeta italianizante y poeta castellano. En todos ellos hay, a mi modo de ver, un profundo sentimiento nacional. La indudable influencia extranjera no pesa sobre sus espíritus. El clasificarlos depende de una cuestión de enfoque histórico. ${ }^{6}$

Esa perspectiva conciliadora descubre entre pares a Garcilaso, modelo renacentista en el panorama hispano, y Castillejo, de tendencia medieval en paisajes compartidos. También aproxima el quehacer de Lope y las tareas de Góngora, ambos figuras emblemáticas del barroco nacional, uno más inclinado hacia el desnudo expresivo; mejor embozado el otro. En cualquier caso, la coherencia poética del segundo, teñida de franqueza, es una de sus virtudes, defendida con soledad aristocrática.

Consiguieron arrinconar a Góngora y echar tierra a los ojos nuevos que venían a comprenderlo durante dos largos siglos en los que nos han estado repitiendo... «no acercarse, porque no se entiende...» Y Góngora ha estado solo como un leproso de fría luz de plata, con la rama novisima en las manos esperando las nuevas generaciones que recogieran su herencia objetiva y su sentido de la metáfora.?

Porque la clave de la escritura gongorina se encuentra en los acertados empleos de la metáfora, injertada en cada una de sus obras para comprimir significados y enriquecer los juegos del lenguaje, advirtiendo que estos merecen estudio; se pierden con lecturas rápidas. Góngora, usando sus imágenes, no viene a buscarnos, como otros poetas, para ponernos melancólicos, sino que bay que seguirlo razonablemente. Fue él mismo, desde sus versos, una revolución lírica que supo responder a la nativa necesidad de belleza, y conduce a un original modelado del idioma.

Inventa por primera vez en el castellano un nuevo método para cazar y plasmar las metáforas, y piensa, sin decirlo, que la eternidad de un poema depende de la calidad y trabazón de las imágenes.

Ya no podía crear poemas que supieran al viejo gusto castellano; ya no gustaba la sencillez heroica del romance. Cuando para no trabajar miraba el espectáculo lírico contemporáneo, lo encontraba lleno de defectos, de imperfecciones, de sentimientos vulgares. Todo el polvo de Castilla le llenaba el alma y la sotana de racionero. Sentía que los poemas de los otros eran imperfectos, descuidados, como hechos al desgaire. ${ }^{8}$

La cuestión del método deriva del propio criterio gongorino, de paladar exquisito rehacio al color local y feroz enemigo de mimetizar lecturas, aún las más entrañables entre las clásicas. Se debe a determinadas consideraciones sostenidas por un espíritu escultórico situado en un ambiente extraatmosférico, desvelando en última instancia su incapacidad para sentir a secas una realidad real, siendo por el contrario dueño absoluto de la realidad
5 Ibidem, pág. 989.

6 F. García Lorca, «La imagen poética de don Luis de Góngora», Obras Completas, T.I., op. cit., pág. 1004.

7

Ibidem, pág. 1005.

8 Ibidem, pág. 1006.
Ecos lorquianos en la memoria poética del Paraguay: Josefina Pla, Augusto Roa Bastos y Hérib Campos Cervera 
«La imagen poética de don Luis de Góngora», op. cit., pág. 1008.

10

Ibidem, pág. 1008.

11 Ibidem, págs. 1011 y 1013.

12 «La imagen poética de don Luis de Góngora», op. cit., pág. 1014. poética, en su más amplia dimensión. Se identifica Góngora como profesor en los cinco sentidos corporales, que ordenará rigurosamente: vista, tacto, oído, olfato y gusto, trazando así las pautas del conocer poético, que otra vez entiende de reglas y acuerda con un decir metafórico repleto de alma.

Para que una metáfora tenga vida necesita dos condiciones esenciales: forma y radio de acción. Su núcleo central y una redonda perspectiva en torno de él [...]. La metáfora está siempre regida por la vista (a veces por una vista sublimada), pero es la vista la que la hace limitada y le da su realidad...

El tacto enseña la calidad de sus materias líricas. Su calidad... casi pictórica. Y las imágenes que construyen los demás sentidos están supeditadas a los dos primeros. ${ }^{9}$

Las apreciaciones gongorinas de Lorca se amplían para comprender un sistema de relaciones que se inicia, cómo no, en la naturaleza de esas metáforas, todavía semejante al léxico de los diccionarios, cuando permanece aislada del entorno expresivo; dispuesta para la sintaxis dentro de una composición, sometida a normas, moldeada con bellos perfiles y siempre organizada para unir dos mundos antagónicos por medio de un salto ecuestre que da la imaginación.

La originalidad de don Luis de Góngora, aparte de la puramente gramatical, está en su modo de cazar las imágenes, que estudió utilizando sus dramáticos antagónicos por medio de un salto ecuestre que da el mito. ${ }^{10}$

Ésta es una de las claves dominantes en poesía, y tratada con privilegio en la de Góngora, ya que sus figuras tienden a desvelar la condición simbólica de los objetos líricos, no importa la entidad, el tamaño o la materia.

Góngora trata con la misma medida todas las materias, y así como maneja mares y continentes como un cíclope, analiza frutas y objetos. Es más, se recrea en las cosas pequeñas con más fervor.

Góngora no crea sus imágenes sobre la misma Naturaleza, sino que lleva el objeto, cosa o acto, a la oscura cámara de su cerebro y de allí salen transformados para dar el gran salto sobre el otro mundo con que se funden. Por eso su poesía, como no es directa, es imposible de leer entre los objetos de que habla. ${ }^{11}$
El camino y los aciertos merecen situar el quehacer gongorino entre los más altos, porque enseña un mundo interior, que no puede espiarse fuera, logrando seducir con toda su potencia; también liberar con todas sus fuerzas. Así lo mira Lorca; con parecido acento se atreve a contarlo; y de semejante cuño son las estrategias de cazador nocturno en lejanisimo bosque.

El poeta debe ir a su cacería limpio y sereno, hasta disfrazado. Se mantendrá firme contra los espejismos y acechará cautelosamente las carnes palpitantes y reales que armonicen con el placer del poema que lleva entrevisto [...]. Su fantasía cuenta con sus cinco sentidos corporales [...]. Intuye con claridad que la naturaleza que salió de las manos de Dios no es la naturaleza que debe vivir en poemas, y ordena sus paisajes analizando sus componentes. Podríamos decir que pasa a la naturaleza y sus matices por la disciplina del compás musical.12

Vuelve Lorca a su referente sonoro aplicándolo ahora a su verdad gongorina, modelo de armonía imposible, pero con hondo sentido, tremendamente lúcida, controlada en sus formas, moldeada con inteligencia y repleta de imaginación, que no es un estado sino un espacio aún por vestir del que se vuelve como cuando se regresa de un país extranjero. No es un despropósito entender que Góngora es un clásico empeñado en ofrecer las claves de una revolución transformada en metáforas. El poeta barroco, tan oscuro, sólo narra historias, dibujando apenas su esqueleto y arropándolas en la carne magnífica de las imágenes. Por eso se habla de dos Góngoras:

El Góngora culto y el Góngora llanista. Las literaturas y sus catedráticos lo dicen. Pero una persona con un poco de percepción y sensibilidad podrá notar, analizando su obra, que su imagen siempre es culta. Aún en los romancillos más fáciles construye sus metáforas y sus figuras de dicción con el mismo mecanismo que cumple en su obra genuinamente culta. Pero lo que pasa es que están situadas en una anécdota clara o un sencillo paisaje, y en su obra culta están ligadas a otras a su vez ligadas, y de ahí su aparente dificultad. ${ }^{13}$

El gusto que declara Lorca por las formas cultas del barroco gongorino no mengua su querencia por las expresiones de origen popular, entendiendo así los contrastes de una 
poesía en tensión, digna de estudio, repleta de sensibilidad y capaz de reconocer su duende en todo lo que tiene sonidos negros:

...el misterio, las raíces que se clavan en el limo que todos conocemos, que todos ignoramos, pero de donde nos llega lo que es sustancial en el arte. Sonidos negros dijo el hombre popular de España y coincidión con Goethe, que hace la definición del duende al hablar de Paganini, diciendo: «Poder misterioso que todos sienten y ningún filósofo explica».

Así, pues, el duende es un poder y no un obrar, es un luchar y no un pensar [...]. Es decir, no es cuestión de facultad, sino de verdadero estilo vivo; es decir, de sangre; es decir, de viejísima cultura, de creación en acto. $^{14}$

Afirmaba Nietzsche que las obras de cualquier artista son el resultado de una lucha contra el propio diablo, no la gracia de los ángeles, que sólo iluminan desde lo alto, o la complicidad de las musas, tan caprichosas y tantas veces sordas a los reclamos. Ese enfrentamiento con una figura demoniaca, más próxima a sus antecedentes socráticos o cartesianos; menos identificada con los de perfil religioso y máscaras literarias, sirve para valorar sus consecuencias, despejar tópicos, rechazar geometrías y advertir derrotas, estas últimas posibles al no disponer de planos y estrategias que garanticen el triunfo, descubierto por el iniciado cuando nota que el espíritu vence a la materia pobre; también cuando estimula en el ignorante una auténtica emoción.

Ese juego violento de poder logra desarrollarse con mayor gracia en los campos de la música, la danza y la poesía hablada, artes que necesitan un cuerpo vivo que interprete por qué nacen y mueren de modo perpetuo y alzan sus contornos sobre un presente exacto. De alguna manera, Lorca establece así prioridades, decantándose a favor de la honda complejidad y simple apariencia, sin negarle aprecios esenciales al complicado artificio y exquisita sensibilidad. La sorpresa pulsa las entrañas; la admiración se provoca con inteligentes maneras; ambas son mestizas y pueden llevar la muerte, el amor y la libertad a cuestas, pero una se mantiene con los pies en la tierra y la otra se mueve desde una imaginación construída a propósito. Aquélla es de honda naturaleza; la segunda de creativa fuerza. En cualquier caso, ¿dónde está el duende?, quizás en algún sitio, cuando

...el arco vacío entre un aire mental que sopla con insistencia sobre las cabezas de los muertos, en busca de nuevos paisajes y acentos ignorados; un aire con sabor de saliva de niño, de hierba machacada y velo de medusa que anuncia el cosntante bautizo de las cosas recién creadas. ${ }^{15}$

Tan ambigua en su exacta definición, esa perspectiva permite afirmar que Góngora y el cante hondo son hijos de la misma madre, pero no siameses. Quienes pretenden situarlos en los extremos, tampoco se equivocan, pero ayudan a entender la naturaleza del círculo mágico que representa el poema, fórmula que

...consiste en estar siempre enduendado para bautizar con agua oscura a todos los que miran, porque con duende es más fácil amar, comprender, y es seguro ser amado, ser comprendido, y esta lucha por la expresión y por la comunicación de la expresión adquiere a veces, en poesía, caracteres mortales. ${ }^{16}$

\section{VUELTA (PARÉNTESIS OPORT'UNO)}

Al principio se anotaba que Lorca nunca estuvo en Paraguay; sí en tierras del Plata, injertándose mejor desde entonces en la conciencia de un público y no pocos autores rioplatenses. De hecho, Lorca desembarca en Buenos Aires cumplido el otoño de 1933, insistiendo en aclarar que su arte no es popular, sino con aire aristocrático, aunque reconoce que va impregnado de raza. También es un hecho que, se aleja de Buenos Aires iniciada la primavera de 1934, declarando en esa ocasión que, durante su estancia, ha tenido la suerte de echar raíces porque ha descubierto

....algo vivo y personal; algo lleno de dramático latido, algo inconfundible y original en medio de sus mil razas y atrae al viajero y lo fascina. Para mí ha sido suave y galán, cachador y lindo y he de mover por eso un pañuelo oscuro, de donde salga una paloma de misterosas palabras en el instante de mi despedida. ${ }^{17}$

Por esa época Lorca ya se debajan sentir en América: alguna de sus piezas teatrales se re-
13

Ibidem, pág. 1022.

14

F. García Lorca, «Teoría y juego del duende", en Obras Completas, op. cit. T. I., pág. 1068.

15

«Teoría y juego del duende», op. cit., pág. 1079.

16

Ibidem, pág. 1076.

17

F. García Lorca, «Discurso de despedida de Buenos Aires», Obras Completas, T.I., op. cit. pág. 1166.

Ecos lorquianos en la memoria poética del Paraguay: Josefina Pla, Augusto Roa Bastos y Hérib Campos Cervera PACO TOVAR 
Josefina Pla, «Siete definiciones de la poesía a través de la obra de Federico García Lorca», El País, Asunción, 24 de febrero de 1945. Pág. 10. cibían con interés, celebrándose con éxito; desplegó su don de gentes; e hizo gala de su histrionismo. No es un despropósito entender que todas esas proyecciones, de orden literario, cualidades escénicas y dimensión humana, tuvieron su eco en aquella zona del Plata; también en los cotos de su interior mediterráneo, donde alcanzó a instalarse en la memoria de una vanguardia poética inaugurada por Josefina Pla, Augusto Roa Bastos y Hérib Campos Cervera.

\section{LECTURA Y HOMENAJE}

Uno de los trabajos más lúcidos de Josefina Pla se ocupa de García Lorca, no para ordenar frases laudatorias o efectuar ejercicios gimnásticos de simple carácter alusivo, sino para definir, con talante literario e impresiones de lector, la misma poesía. El texto, publicado en febrero de 1945, da noticias del asunto a tratar en sus párrafos liminares:

Los versos de Lorca -avenida de álamos de platarebrillan inmovilizados en solsticio lozano. Cuando acabamos de leer sus versos tenemos la sensación de haber hallado de nuevo la poesía. Que es como decir que deseamos una nueva definición. Sus poemas tienen acento de presagio, porque todos ellos son voz prestada a lo que fue, y el presagio no es sino un remorder de lo definitivamente olvidado. Vienen de eternidad y van a eternidad, bogando por el río efímero de nuestra sangre.

Así, herederos de sus versos - laberinto entretejido de soles desvelados y lunas y mares por abrir - hemos de componer nosotros mismos la clave para atravesar su recinto metafórico y alcanzar el reducto final, donde la verdad acorralada se da vida y más semejante a uno mismo. ${ }^{18}$

Establecidas las señas, Josefina Pla ordenará sus definiciones, regidas todas por una cifra mágica y cada una de ellas mediante una palabra: cintra, nombre que identifica en arquitectura los puntales de apoyo situados en en los vanos de acceso a las diferentes estancias de una construcción, imposible de sostener $\sin$ la ayuda de ese elemento estructural, compuesto para la ocasión de piezas poéticas extraídas en yacimientos lorquianos: Libro de poemas (1921), Primeras canciones (1922), Romancero gitano (1927) y Poeta en Nueva York (1929-1930). Esos pocos materiales sirven para mantener la estructura de un trabajo que re- mite a sus antecedentes lorquianos y alcanza a definir la poesía.

La primera cimbra remite a "Cantos nuevos», y permite el acceso a las estancias del sentimiento melancólico, esa bilis negra de origen visceral reconocida en el quehacer poético bajo la máscara que le proporciona un término clásico de amable eufonía y diferente explicación: como hecho científico, por ser una secreción del organismo que responde a los estímulos del exterior; como materia de estudios sicológicos, por ser la manifestación de una angustia residual, derivada ésta principalmente, según la escuela freudiana, del impulso sexual, ya escondido en la memoria, y la evocación de la muerte, siempre presentida. En cualquier caso, todos esos registros forman parte de un yo que se debate a solas con sus duendes, tratando de expiar viejas culpas o de recuperar la inocencia primitiva. En este orden de cosas, la literatura no será sino el esfuerzo de la humanidad por olvidar, recordándolo, que está desnuda; la poesía, el intento de un regreso imposible.

«Madrigal de verano» $\mathrm{y}$ «Romance de Thamar y Amnón» sostienen la segunda cimbra, que da entrada al salón del erotismo, más próximo a la sugerencia que a las descripciones minuciosas de la actividad carnal. Plantear ese rasgo diferenciador no es gratuito, porque la versión directa satisface carencias en la especie animal, engañándola con sus farsas; la simbólica formula un rito que exige cómplices entre los miembros de una raza sensualmente satisfecha, pero dispuesta a identificarse frente a los verdaderos artificios. La segunda cumple su función de círculo mágico, encerrando en sí misma el tremendo espectáculo de la vida y de la muerte, ambos enlazados e inagotables también en la poesía, donde todas las formas advierten que no es lo que es, sino lo que está llegando a ser.

Cimbra de entrada al salón de los juegos adolescentes manchados de vejez son «Remanso», «remansillo» y "canción de las siete doncellas». Contemplar esas representaciones permite enfrentarse a la historia, no como testimonio, sino desde su raíz mítica, ya alumbrada por las musas de Hesiodo, el Daimón de Sócrates y los fuegos de Byron, Shelley, Heine, Hölderlin, Schiller y De Vigny. Encontrarse con tan entrañables sombras evita soberbias y ayuda a crear poesía, que se define ahora como becho ontológico de concepción; su sentido 
se bace claro en esa implícita multiplicidad posible de formas.

Es «Palimsesto» cimbra del propio hermetismo, también localizado en «Elegía del silencio», donde todo se encuentra fuera de la realidad y dentro de lo que algunos llaman vicio escenográfico, sin entender que dentro de ese espacio suspendido está la explicación del hecho representado y la claridad de su poesía, sombra que - para seguir el paralelismo con los teoremas de óptica-llega hasta el cuerpo luminoso.

«La canción del mariquita» es cimbra que permite ver qué el color tiene el sonido, saborearlo y recuperar su melodía, ya repleta de aromas intensos y verdaderos ensueños poéticos. Ese proteísmo sensorial es señal de vida por ser visión onírica, "asíntota del sueño", del mismo modo que la palabra es la asintota de la idea.

Situar la cimbra en «Romance del muerto de amor» es reconocer la sala grande ocupada por el Romancero gitano, lugar de cita con toda la poesía lorquiana de ropa popular y profundas metáforas, éstas repletas de perfiles raciales, cuerpos sensuales, manantiales cristalinos, amables rumores, humildes secuencias, rayos de sol, reflejos de musgo..., todos brindando luego con las oscuras etnias, tensos sensualismos, impresiones urbanas y paisaje artificial de Poeta en Nueva York. No basta evocar en ese juego a Walt Whitman; también cuentan, sin agotar la nómina de recuerdos, Fernando de Rojas, Calderón, Moreto, el Arcipreste de Hita, Santa Teresa o Ignacio de Loyola, todos instalados en el sentimiento trágico de una poesía que es la forma más ajustadamente sensible a la muerte.

Última cimbra, la «Oda a Dalí» descubre el gabinete secreto de los estiletes líricos, armas de un escritor que penetran en la porción más múltiple, estriada e inquietante de la lírica; también en la más oscura, no por falta de luz, sino porque se despliega en múltiples formas cromáticas, filtradas, como en la «oda a Walt Whitman», en la sombra arterial de su árbol venoso. Lo que importa es entender que que la poesía es una sola, pero distinta para cada uno, ahí está la verdad de su signo y el espacio de cita con la eternidad. De ahí surgen las siete definiciones de la poesía, sintetizadas en que no tiene ninguna, motivo suficiente para rendir al poeta muerto el único homenaje

cifrado que se le debe, ahora reducido al trozo que la concluye:
Federico García,
Por doce puertas rojas la muerte te quería.
Las abrió como doce
Versos de rojas consonantes.
-Eran la muerte larga que tu verso conoce-
Doce bocas de versos te cantaban, amantes.
La besaste con labios de doce versos rojos.
Ella, amorosa y lenta, se te acostó en los ojos. ${ }^{19}$

\section{APUNTES Y DESPEDIDA}

Seña de identidad paraguaya más profunda es la música, afirma por convicción Augusto Roa Bastos, dispuesto a reconocer que ese rasgo, junto al de la propia tradición oral, puede compartirse con otros pueblos que dispongan de suerte semejante, pero no alcanzarán el acento dominante que modula el Paraguay, porque así, dice Roa,

...traduce nuestro temperamento y revela nuestra sensibilidad en sus tonalidades peculiares, en su color fundamental. La música es como la piel de nuestra vida nacional; una piel tensa y vibrante bajo la cual se perciben los latidos del corazón de nuestro pueblo, se adivinan sus impulsos y se intuyen sus ansias. ${ }^{20}$

Esa característica remite a los primeros tiempos de una historia que surge por los resquicios de la memoria común, articulada en sonidos hondos y modulada voz profunda, ambos al ritmo continuo del sentimiento y al compás de un rito que estimula a sus artistas más primitivos. Firmes contra el espejeamiento de formas y apariencias, cada uno de esos señores confirma

...la prolongación de una gran línea de generación estética que no puede detenerse en él y que debe fluir como una vena irrepresable por el cauce siempre activo de la emoción popular de cuyo hondón surge y al cual torna invariablemente. ${ }^{21}$

Ya logró asombrar el instinto musical paraguayo al español recién llegado, aconsejándole usurpar ese recurso para reducir a sus indígenas, que cantando nacieron y cantando habrán de morir, sin perderse del todo por el camino y dando noticias de su entrañable
19

Josefina Pla, "Federico García Lorca», El País, Asunción, 12 de julio de 1944.

De clara influencia lorquiana son también, entre otras, las piezas: «El poema del creciente» $y$ «Lo casada infiel». La primera, de registro popular, fechada en 1940 e incluída en De la imposible au sente (inédito en vida de la poeta, pero recogido en sus Poesías completas de Josefina Pla, edición de Miguel Ángel Fernández, El Lecior, Asunción, 1996); la segunda, de 1978, en forma de soneto, comprendida en La llama y la arena (Alcándara, Asunción, 1985).

20

Augusto Roa Bastos, «La música y el carácier nacional paraguayo", Suplementos Anthropos. Antologías Temáticas (Augusto Roa Bastos, Presentación y selección de textos: Paco Tovar) n² 25, 1991, pág. 72. El original forma parte de una conferencia del escritor pronunciada en Asunción (Asociación de Músicos del Paraguay, 20 de diciembre de 1946), cuyo resumen se publicaría inicialmente en El País (Asunción, 7, enero, 1947); más tarde en la Revisfa del Afeneo Para guayo ( $n^{\circ}$ 17, febrero-marzo, 1947).

21

«La música y el carácter nacional paraguayo», op. cit., pág. 73.

\footnotetext{
Ecos lorquianos en la memoria poética del Paraguay:

Josefina Pla, Augusto Roa Bastos y Hérib Campos Cervera PACOTOVAR
} 
Ibidem, pág. 73.

23

Ibidem, pág. 75.

24

«La música y el carácter nacional paraguayo», op. cit. pág. 78.

25

A. Roa Bastos, «Sobre el sentido ascético de la poesía nueva», Poesías reunidas, Miguel Ángel Fernández (ed.), El Lector, Asunción, 1995, pág. 261. El original remite a noviembre de 1943 (Revista del Ateneo Paraguayo, año $2, n^{\circ} 8$ ).

26

Ibidem, pág. 263.
Ecos lorquianos en la memoria poética del Paraguay:

Josefina Pla, Augusto Roa Bastos y Hérib Campos Cervera PACO TOVAR fuerza en cualquiera de sus tareas y momentos cotidianos.

Entonces las noches se llenan de bordoneos pueblerinos y de canciones hondas que parecen brotar de los surcos y los ramajes, enredados al chisporroteo hondulante de las luciérnagas.

Hay desgraciadamente muchos paraguayos que no saben leer, pero en compensación hay muchos menos que no saben tocar la guitarra.

Tenemos, pues, entonces, en orimer término, un instinto, una vocación, que es decir casi todo..$^{22}$

Razón de ser y vocaciones de estar configuran así los perfiles de un folklore lúdico y tremendo, dando las pautas de unas relaciones difíciles entre los dos ámbitos de una sola cultura con acento guaraní y rostro castellano, figura esta de un Jano particular empeñado en divertirse y dispuesto a mantener sus formas clásicas.

El pueblo no utiliza ya la música para acompañarse en los momentos de expansión de unos ritmos más o menos vivos, y de unas melodías más o menos pegadizas. Sus fiestas indudablemente se han dignificado. Por sobre los bailes campesinos, sus canciones, sus fogosos zapateos, su rumor alegre y expansivo, flota en la guaranía, en el Kyre /yn o en la misma polca, algo nuevo que llena el alma sencilla del hombre del pueblo de esa satisfacción indefinible que es ya presencia del placer estético logrado por la autenticidad del $\operatorname{arte}^{23}$

Difícil acuerdo mantener islas y construir puentes en tierra con raíces mestizas y tensión permanente, salvo en esa música repleta de matices que se debate, por cuestiones de lengua, entre la armonía oral y los armónicos de la escritura; peor solución cuando el problema se desvía con asuntos de cuño social, debatidos en forjas dominantes, por decreto a golpes, y talleres dominados, condenados al cierre por defunción y silencio. Esas cuestiones también juegan en el tapete literario y la de menor entidad espera una suerte que sólo puede proporcionarle la sedimentación paulatina de la literatura en español, decantada en filtros paraguayos, o la aparición de un talento genial, con registro guaraní, ambos en ejercicio de caballeros, no en lucha excluyente. Bastantes demonios tienen los dos para entretenerse de poder a poder con falsos duendes. Mejor reunirse sumando ángeles oscuros en
Un refugio transparente por el ensueño, un espejo cristalino para el rostro de nuestra alma, un templo para los ritos conmovidos de la emoción y una trinchera para la batalla del hombre con su destino. ${ }^{24}$

Roa no apuesta en ese truco por la tensión estática, sorda en su pulso musical, tímida en sus voces y copiada de rasgos, propia de talantes conservadores, gestos conformistas y talante nostálgico, cuando no sometido. Invita a seguir en trincheras literarias, manejar nuevas armas y vestir uniformes de trabajo, defendiendo el instinto de perpetuación con verdaderos artificios y reales invenciones. Se trata de liberar la historia creándola con palabras; intuyéndola, no pensándola esa nueva poesía que, entre otros, cita en su favor a Neruda, Alberti y, cómo no, a Lorca, todos comprometidos en un hecho literario, tan primitivo como el dolor de hoy, verbo de mañana. Esa expresión estética sentida, de misterioso origen y cuidada forma prefiere su condición ascética, otro modo de entender el estilo barroco no a la manera de Góngora sino cortando a medida los vestidos que cubren la materia del espíritu, no para deshumanizarlo, sino por humanarlo una vez destemporalizado en su más amplia realidad poética.

El objeto de la poesía no es trasuntar la realidad, sino acrecer sus fronteras. No es un espejo. Es una antorcha. La poesía empieza donde lo real termina, y su misión es crear nuevas realidades. Harto se concibe que para el poeta moderno, lo irreal no es lo que no tiene existencia absoluta, sino sencillamente lo que no la tiene todavía. ${ }^{25}$

Velada, la cita de Josefina Pla en una de sus definiciones; también la memoria de Lorca, con sus imágenes; ambas bajo el palio de la metáfora, de nuevo elemento imprescindible como cimbra que ha de sostener la construcción poética, resolviendo un problema de fuerzas contrarias. El decir con metáforas no es una

Oposición de dos entidades afines, sino, inversamente, la superación de esa relación de identidades que hay entre el objeto y su representación. No interesa en la metáfora que lo metaforizado conserve un aire familiar con su objeto, lo que interesa es que la metáfora lleve en sí misma incapsulados objeto y sujeto, es decir, que sea idéntica a sí misma. ${ }^{26}$ 
No olvida Roa que para conseguir ese equilibrio de fuerzas ensimismadas cuenta con el buen uso de los mitos, profunda historia y verdadera fantasía en molde religioso y con valor simbólico, a semejanza de la escritura injertada de esas formas reales que deben ser bien leídas para entender lo que dicen

Esa lectura de la realidad por medio del mito no es, entonces, como muchos creen, una huida al pasado, una regresión a la matriz intemporal de la fábula, el refugio de una inmovilidad fetal. Esta capacidad de una lectura simbólica a todos los niveles de la realidad permiten integrar el pasado, el presente y el futuro en la magnitud de un tiempo viviente en el cual el individuo y la sociedad pueden intuir en un relámpago el secreto de su identidad y plantearse sus interrogantes fundamentales, tal como lo demuestra precisamente la función simbólica del lenguaje. ${ }^{27}$

La correspondencia lenguaje-mito, o la inversa, es una relación misteriosa que se repite entre la verdad y la mentira, la claridad y las sombras, la vieja tradición y la cultura aprendida, el poder y la servidumbre, las formas y el sentido, el amor y la muerte..., todas reunidas en la poesía para para ofrecer el espectáculo de la vida y la muerte cantadas a solas dentro del propio círculo mágico, este repleto de armónicos, murmullos y fantasías extraídas de una conversación abierta con la realidad y sus artificios. En ese espacio cuentan los hondos sonidos de Lorca.

\section{ECOS DE ESCRITURA}

como un mendigo ciego

yo imploraba en secreto tu voz, tus alas rotas, tu vida de soldado destruida, el resplandor visible de tu fuego que en el costado izquierdo de la patria, lejos o cerca de ella, era su antorcha melodiosa, su combatiente estrella y el pulso musical de su destino.

Tu voz canta y solloza en las distancias Y fulguran celestes tus pupilas Sobre el pavés de los jazmines, Sobre las alas de los pájaros, Sobre los labios que te llaman...

Entre los rascacielos te despido
De esta ciudad a orillas del río como mar,

Con su pueblo profundo

En cuyo umbral

Te inclinaste a dormir alucinado

Bajo el cielo del sur.

:.................................:

Mi mano de poeta

Queda clavada aquí, sobre tu cruz,

Por siempre. ${ }^{28}$

Son trozos de una pieza construída por Augusto Roa Bastos para despedir con homenaje a un poeta amigo, muerto en Buenos Aires: Hérib Campos Cervera; también para iniciar un retiro voluntario de la poesía.

Estoy aquí, sin voz y sin presencia;

Limpio de luz con mis duras anclas

Mordiendo las tinieblas de granito

Que duermen en la boca de mis túneles.

Te encuentro en este claro mediodía cavando

Cauces, donde el latido del agua no tenía

Ningún trigo guardado para que diera el surco

Su pan de voz morena, maduro de presente.

Traes un alba de música distinta en la garganta:

Se siente que no quieres llevar la misma luna

Que solicita el zumo vegetal de otras voces.

Por eso: porque vienes sin ley de gratitud

Tu verso tiene tanta cargazón de llamados

Para el Clavel y el Agua y el Viento que manejas.

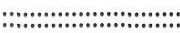

Y que la liberada palabra de los años

Te encuentre siempre al pairo del sol más justiciero,

Para que no haya herrumbre sobre tu nombre claro:

Capitán de esta aurora que no tiene silencios...29

Es parte de la respuesta que el mismo Hérib Campos Cervera, aún vivo, dirige a Roa, en diálogo consigo mismo, y nunca hubiera podido escribir si no rompe, como hizo, las reglas del tiempo y la ley de los muertos, liberando en esas formas su fuerte intuición poética. Los interlocutores, en sus juegos de palabras también disponen de un testigo común en los ecos que les proporcionaría Lorca.

«Responso» es la pieza de Hérib Campos Cervera que más se aproximan a los registros lorquianos, tanto por el semejante empleo de recursos literarios como por descubrir las emociones de su autor ante la muerte. El poema no responde al simple testimonio de
27

A. Roa Bastos, "El buen uso de los mitos», Suplementos Anthropos, op. cit., pág. 79. El original se publicaría en Acción (Asunción, IV, 12, octubre, 1971).

28

A. Roa Bastos, "Adiós a Hérib Campos Cervera», El naranjal ardiente, Diálogo. Libros de la Pirririta, Asunción, 1960.

29

Hérib Campos Cervera, «Capitán de esta aurora», Ceniza Redimida, Editorial Tupá, Buenos Aires, 1950, págs. 57-59.
Ecos lorquianos en la memoria poética del Paraguay: Josefina Pla, Augusto Roa Bastos y Hérib Campos Cervera PACOTOVAR 
30

Hérib Campos Cervera, «Responso", Poesías completas y otros texios, Miguel Ángel Fernández (ed.), El Lecior, Asunción, 1996, págs. 199-200. El editor incluye esta pieza, fechada en 1947, bajo el epígrafe de «Poemas no incluídos en Ceniza redimida».
Ecos lorquianos en la memoria poética del Paraguay: Josefina Pla, Augusto Roa Bastos y Hérib Campos Cervera una experiencia dolorosa, cuidadosamente descrita y capaz de reclamar la atención de curiosos ante un suceso irreparable; logra crear su atmósfera, ofreciendo la visión trágica de un espectáculo donde cuenta tanto la realidad del hecho como su memoria, uno y otra desarrollados en la materia un rito trágico de origen histórico, perfil sentimental, formas adecuadas y condición simbólica.

Precedida de una dedicatoria, donde se identifica la persona que merece el recuerdo del escritor, la naturaleza campesina de ese personaje, el soporte que ha de servir para dibujar los versos y el carácter de oración que se le reconoce a estos últimos, la estructura fragmentada del poema permite seguir los diferentes cuadros de su representación, alternando en ellos las formas de apariencia culta y las de aspecto popular, ambas repletas de metáforas acuñadas en tono trascendente. Así da cuenta en primer lugar de una escenografía, un personaje y unos rasgos de este último, ya situados fuera del tiempo y dentro de las sombras, todo ello de mágicas dimensiones concéntricas y con oportuno vigilante:

En memoria de Juan de Dios Talavera -un «mensui» que conoci en vida y muerte-, escribo en el agua del río inmenso, este Responso.

\section{I}

Lo custodian cien círculos transparentes y un pájaro. Y una desesperada soledad de domingo.

Baja por la corriente, viajero de su muerte,

Llevando sus dos párpados con su noche y su frío.

Cuando labios helados llamaron al desvelo

Y la sangre se fue por su camino:

Dos violetas nocturnas y un clavel sin memoria

Le ajustaron la máscara sobre el rostro dormido.

Manos de obscura ciencia y oficio mercenario

Le buscaron un túmulo de muros imprecisos,

Y hoy navega sin brújula, sin puerto y sin sosiego,

-viajero de su muerte-, por el río.

\section{II}

Manos de jazmín antiguo;

Brazos de intensa madera.

Sombra nocturna del pelo

Bajo la luna bermeja.
Presencia helada de hierro

Que torvamente navega,

Cruzando sobre el silencio

De una guitarra sin cuerdas.

Ay,jmuchacho navegante!

Ay ¡Juan de Dios Talavera!

¡Cómo te nombro y te sueño

frente al alba sin estrellas!

¿Por qué me vienes bajando

llenos los ojos de niebla?

¿Dónde están tu faz de cobre

y esa garganta morena

que moría en las bordonas

cuando cantabas tu queja?

¡Cómo te llevo conmigo,

Juan de Dios de mi tristeza!

¡Cómo arañan mis recuerdos

tus dos manos de azucenas! ${ }^{30}$

En segundo término, se repite el esquema anterior, esta vez para reconocer la escritura como materia representada, encuadrada en tiempo verbal presente y con amplia muestra central en verbo pasado:

\section{III}

Todo aquello que puede nombrar a un ser venido

Por un claro sendero de música y claveles,

Vivía en este dulce paraguayo que baja

Solo y vestido de temprana muerte.

Vivió un juego de magia inaccesible:

Bajo las catedrales del oro y de la fiebre,

Lo cuidaba una imagen sin fatiga y sin párpados,

Velando siempre...

Todavía las muertes juntas custodiaban su vida:

La bota de cien leguas de la lluvia perenne;

El universo azul de las orquídeas

Y el aire poderoso de los infiernos verdes.

(Todo vivía allí, pero ay, amigos,

el tiempo de vivir estaba ausente)

\section{IV}

Hierros de voces opacas

Le salieron al encuentro:

Una guitarra invisible

Puso su nombre en el viento. 
Embrujos de pelo obscuro

Se encendieron a lo lejos

$Y$ un llamado de jazmines

Le amortajó los recuerdos.

Bajo la luz de la frente,

Sollozaba un largo silencio.

Ay!, en el medio del río

Ya el corazón está quieto.

Frente a la tarde impasible

Corre el agua, va corriendo:

Juan de Dios, sigue que sigue,

Solo, sin voz y sin puerto. ${ }^{31}$

Resulta evidente que, por sus paralelismos formales y con tanta semanza de imágenes, logra distanciarse del calco por los detalles que introduce, añadiendo matices de particular esencia paraguaya teñida de muerte, dolor y sangre propios del mediterráneo paraguayo, reducido a unos pocos términos. En última instancia, Hérib Campos Cervera es un poeta de su tierra, reservándole a Lorca un puesto de privilegio en la memoria poéti- ca que le corresponde, vuelta a resumir en trozos de emocionado recuerdo vivo, dirigido en fórmula epistolar a Federico, ya difunto compañero:

Federico: los años han secado tus carnes; En ellas han penetrado gusanos de la tierra;

Pero tu voz remota, poderosa de símbolos, Como el mar, no está muerta...

Entre un vuelo de albatros y un tumulto de estrellas, Se volvió al infinito tu fiesta de canciones.

Cuando pasen mil años, junto a esta misma piedra Que destacó tu estampa sobre el telón atlántico, Aún estaré esperando que otra música análoga Taladre el laberinto de cal de mis oídos. ${ }^{32}$

\section{PENÚLTIMO COMPÁS, Y SUERTE}

Una muy breve conclusión para tanto aparejo: Lorca, se dice, nunca fue a Paraguay... Mentira. Cuando poco, estuvo allí con Josefina Plá, desde Roa Bastos y según Hérib Campos Cervera.
31

«Responso», op. cit., págs. 200201.

32

Hérib Campos Cervera, "Federico», Ceniza redimida, op. cit., págs. 51-52. 


\begin{abstract}
Rubén Bareiro Saguier
Poeta, narrador, ensayista y crítico literario nacido en 1930. Abogado y licenciado en Letras por la Universidad Nacional de Asunción, Bareiro Saguier reside desde hace muchos años en París, donde se desempeñó como catcdrático universitario de literatura hispanoamericana y lengua guaraní. Desde julio de 1994 representa a su país como Embajador del Paraguay en Francia. Crítico y ensayista de renombre, Bareiro Saguier es también uno de los escritores paraguayos más conocidos en el exterior. En 1971 se le concedió el prestigioso premio Casa de las Américas por su colección de cuentos Ojo por diente (1973). En narrativa publicó después El séptimo pétalo del viento (1984), una segunda antología de cuentos; y su labor ensayística incluye, además de numerosos ensayos críticos, los siguientes estudios: Literatura guarani del Paraguay (1980), Augusto Roa Bastos; semana de autor (1986) y Augusto Roa Bastos; caídas y resurrecciones de un pueblo (1989). De su obra poética se destacan los poemarios Biografía de ausente (1964), A lo vibora de la mar (1977) y Estancias, errancias, querencias (1985). Es también co-editor (con Carlos Villagra Marsal) de Poésie Paraguayenne du $X X e$ Siècle, antología bilingüe (espanol-francés) publicada en Suiza en 1990 (Datos del Breve Diccionario de Literatura Paraguaya de Teresa Méndez-Faith).
\end{abstract}

Epílogo

RUBEN BAREIRO SAGUIER

\title{
EPÍLOGo
}

\author{
RUBEN BAREIRO SAGUIER
}

Ko ñane retã sorokuemíme, en nuestro pequeño deshilachado y entrañable Paraguay, además de los esporádicos intentos golpistas y de una - felizmente - decreciente tradición de gobiernos autoritarios, tenemos un producto interior bruto no tan significativo como el de otros países del continente, pero digno de consideración. Sin embargo, nosotros mis mos rara vez incluimos en las microcifras de la riqueza nacional nuestros mejores exponentes culturales: la lengua guaraní, nuestra música, nuestras artes y el preciado bien que es la literatura. Más rica de lo que se suele pensar - sobre todo por parte de los editores-, algunos fuimos una avanzadilla en su estudio, y nos dedicamos, desde el exilio, a difundir las mejores obras y autores $y$, al mismo tiempo, el conocimiento de nuestra lengua ancestral y viva, que nos otorga signo propio como pueblo y, de cierta manera se constituye en América como ejemplo de país que asume una lengua amerindia como oficial, al par de la que España nos legó.

Entonces no teníamos tantos autores como ahora. Ni esa riqueza de tendencias visible en sus creaciones. He manejado la cronología de obras narrativas paraguayas publicadas que, con ahínco ejemplar, ha incluido José Vicente Peiró en su magistral tesis doctoral, y pienso en cuántas hubiéramos analizado allá por 1960/70, si hubiéramos sido capaces de difundir el conocimiento de tantos escritores compatriotas en busca de un lector - parodiando a Pirandello. En Paraguay, ese lapso fue quebrado por el signo del exilio (exterior/interior), reduciendo el empuje de nuestra tarea cultural. Animados por el entusiasmo cordial de un entrañable y fino estudioso precursor, Jean Andreu (profesor en ToulouseLe Mirail), tratamos de consolidar un grupo de investigación de la cultura paraguaya. Se consiguió. Sin ánimo alguno de arrogancia, trabajamos y abrimos una puerta hasta entonces cerrada en la vieja Europa. Los múltiples encuentros, coloquios, mesas redondas, conferencias, asignaturas en la Universidad Le Mirail, quedaron plasmados en un número especial de la revista de ese centro universitario «Caravelle» ( $\mathrm{N}^{\circ}$ 27/1976). Números especiales de publicaciones similares fueron dedicados a la literatura paraguaya y a su cultura: «Europe» (No 494, Paris/1976), «Co-Texte» (No 14/1987) Universidad de Montpellier, dirigido por Christiane Tarroux-Follin.

Nuestros estudios han quedado como una referencia que parece no haberse extinguido, a juzgar por las citas de las bibliografías de los trabajos actuales.

Se siguió trabajando, humildemente, con mucha convicción, pese a no tener ningún apoyo de nuestro propio país, inmerso en la oscuridad de la dictadura. Intentábamos encender la luz que en nuestra propia tierra se había apagado. Puedo asegurar que mi trabajo iniciado en la revista Alcor, fundada en 1954 con Julio César Troche, en Asunción de las tinieblas, prosiguió y dio sus frutos apetecibles, aunque lo pagáramos con la persecución, las cárceles, las vejaciones y luego el exilio. Revisamos multitud de aspectos pocas veces tenidos en cuenta o que eran silenciados por el servilismo, con objetividad y sin miedo, y en Francia pudimos escribir con la libertad que nuestro país no nos ofrecía. Por mi parte, era una manera de estar en mi patria desde la lejanía física.

El tiempo ha pasado. Sólo unas décadas y la dictadura contra la que luchamos agonizó, aunque durante los últimos años hayamos contemplado su fantasma y luego sufrido su 
herencia maligna, puesto que no es tán fácil extinguir hábitos de intolerancia arraigados desde hace tiempo en un pueblo que no ha conocido demasiados períodos de convivencia pacífica. Quizá la difícil transición a la democracia no haya satisfecho todos los anhelos de quienes lucharon por su vigencia en Paraguay. Pero mejor es compartir que aniquilar. Lo han comprendido las generaciones más jóvenes, afortunadamente. Y lo comprederán mejor cuando la reforma de la educación - el proyecto altamente positivo de futuro vigente desde 1994- y en ese marco, la enseñanza bilingüe dé sus frutos patentes.

También pasaron los tiempos en los que con seis o siete nombres cumplíamos la deuda con nuestro país. Estos autores que estudiábamos no han desaparecido, aunque algunos sí lo hayan hecho físicamente. Perviven. Pero no son los únicos. Como tampoco es Francia el único refugio europeo desde el que se estudia la literatura y la cultura de mi entrañable patria en la actualidad.

Cabe hacer, a esta altura, un rápido recuento del interés iniciado en la Universidad de Toulouse, a partir de los trabajos de Jean Andreu - personales, y los encargados a sus discípulos - ya que me vi profundamente implicado en ellos. Al citado se sumaron progresivamente: Christiane Tarroux-Follin (esta brillante investigadora enseña en la Universidad de Montpellier), Claude Castro, autora de una tesis sobre Caballero, la novela de Guido Rodríguez Alcalá; Dominique Bouzigues-Lamoise, quien defendió una tesis, cuyo título es Memoria y raíces: la obra de Rubén Bareiro Saguier y Gerard Gómez, docente de la Universidad de Aix-en-Provence, quien obtuvo un doctorado con un voluminoso trabajo: El bibridismo cultural de la sociedad paraguaya transcrito por Rubén Bareiro Saguier (19581998). Con los arriba citados, a los que se sumaron Iris Jiménez, Carla Fernandes y varios más, se creó la asociación Paraguay Temimbou, que en marzo de 2000 realizó una primera reunión internacional de estudiosos de la literatura y cultura paraguayas en Toulouse, con la participación de los nombrados y de especialistas de otros países europeos.

Por primera vez se contó con la presencia de escritores venidos especialmente de Paraguay para un evento semejante: Raquel Saguier, Renée Ferrer y Guido Rodríguez Alcalá trajeron la voz de la tierra, permitiendo así un diálogo vivo, un intercambio fecundo entre escritores paraguayos e investigadores de sus obras y la realidad cultural de nuestro país. E1 evento se denominó VOCES DEL PARAGUAY y los temas expuestos por los tres participantes venidos del país fueron: 1) Literatura y cultura, 2) En torno al cuento y 3) Democratización y cultura en el Paraguay. Las ponencias fueron ampliamente discutidas. Como representante oficial y escritor de una promoción anterior, me tocó el cometido de presidir las sesiones y de coordinar las intervenciones del público.

Es de mencionar, en un marco particular, a Milagros Ezquerro, quien fue docente en la Universidad de Toulouse, en la que sostuvo una Tesis de Doctorado de Estado sobre la obra de Augusto Roa Bastos, en especial sobre Yo el Supremo. En su tarea profesoral, Milagros siguió interesándose en la obra del citado novelista, sobre la cual dirigió - y sigue dirigiendo- múltiples tesis. Actualmente Ezquerro es profesora en la Universidad de Montpellier, después de enseñar en la de Caen.

Por otro lado fue posible editar, en francés, a varios autores paraguayos: Gabriel Casaccia, Augusto Roa Bastos, Elvio Romero y yo mismo. También fueron publicadas tres autoras: Raquel Saguier, la novela La niña que perdí en el circo, Renée Ferrer: Desde el encendido corazón del monte (cuentos ecológicos) y la novela Los nudos del silencio, Lourdes Espínola, dos poemarios: Encre de Femme y Las palabras del cuerpo (Les mots du corps).

Escritores de nuestro país integran múltiples antologías dedicadas exclusivamente a nuestra poesía elaboradas en coautoría con Carlos Villagra Marsal: Anthologie de la poésie paraguayenne du XXème Siècle (bilingüe, español-francés) y Anthologie de la poésie guarani du Paraguay (trilingüe, guaraní, español - traducciones de los autores citados - y francés). Ambas aparecieron en las Ediciones Patiño, en Ginebra.

A propósito del estudio del guaraní, la universidad francesa ha realizado una ingente tarea, gracias especialmente al maestrazgo del profesor Bernard Pottier, estudioso de las lenguas amerindias.

En el Institut des Hautes Études de l'Amérique Latine, primero, y luego en la Uni-
Epílogo

RUBEN BAREIRO SAGUIER 
versidad de Paris X - Nanterre, Bernard Pottier creó una enseñanza de las mismas en el marco de su cátedra de lingüística. Solicitó mi ayuda; con un asistente, el guaraní se convirtió en la lengua amerindia usada como modelo. La circunstancia me condujo a estudiarla con especial interés; de simple bilingüe, me volví un curioso buceador de mi lengua raigal. $Y$ al poco tiempo, inscribí un tema de tesis: $D e$ la literatura guarani a la literatura paragnaya: un proceso colonial. Con él obtuve posteriormente el título de Doctor de Estado en Letras y Ciencias Humanas.

Cuando se creó el Centro Experimental de Vincennes, en 1969 (Universidad de Paris VIII), bajo la dirección del citado Profesor Bernard Pottier se constituyó la Cátedra de Lenguas Amerindias, en la que se enseñaron: el quechua, el nahuatl, el maya y el guaraní. El Director del Departamento me encargó de la enseñanza de la última. Con modificaciones, el Departamento sigue existiendo; el guaraní continúa enseñándose, bajo la responsabilidad de Michel Dessaint, que fuera mi asistente en Paris VIII.

De esa larga y cordial tarea salieron varias tesis, libros y artículos, que dan cuenta de un país que con su bilingüismo rinde merecido homenaje a la lengua de sus antepasados amerindios. Cabe citarse la excelente tesis de Michel Dessaint: La langue guarani du Paragnay. Esquisse d'une typologie interne du guaraníparaguayen contemporain; la de Silvio Liuzzi: Temps et aspects en guarani; la de Christine Gillard: Le plan d'enseignement bilingue au Paraguay. Incidences sociolinguistiques y la de Delicia Villagra-Batoux: El guaraní paraguayo: de la oralidad a la lengua escrita. Éste es el trabajo más completo y sólido sobre el guaraní paraguayo, desde el período precolonial hasta nuestros días, elaborado con rigor científico por la citada lingüista y filóloga de sólida formación y gran sensibilidad. En todos ellos me tocó el papel de consultor y miembro de jurado.

Mención especial merecen los trabajos de dos antropólogos franceses, Hélène y Pierre Clastres. Éste, además de sus obras sobre la sociedad y el estado de los guaraníes, tradujo al francés el Ayvu rapytá - recogido por don León Cadogan -, la maravillosa cosmogonía de esa cultura, y lo hizo con gran calidad poética y excelentes comentarios exegéticos.
Y paro de contar, inclusive si hay más cosas que decir del interés que, de una u otra manera, nuestra cultura y literatura están presentes en Francia. Ahora que he realizado una apretada síntesis, me doy cuenta de ello.

Pero como decía más arriba, Francia no es el único país que demuestra ese interés. Prueba de ello es la rica antología temática, trabajo ejemplar de Gabriella Dionisi, en Italia. Los excelentes trabajos de Sonja Steckbauer y los del guaraní y su literatura de Wolf Lustig, en Alemania. Y hasta en un escondido país, como Bulgaria, se ha estudiado el cuento paraguayo, de la mano de Reni Marchevska. Ni digamos en Estados Unidos, donde la infatigable y prolífica Teresa Méndez-Faith continúa con su obra proteica, junto a otros calificados profesores como Betsy Partika o Ronald Haladyna. Asimismo, es altamente loable el número especial de la revista Exégesis dedicado a nuestra literatura, que dirigió el profesor Marcos Reyes Dávila, en 1996. O desde nuestros países vecinos, sobre todo Brasil, donde se empeñan en valorar nuestro pasado y nuestro presente con gran rigor, como en el caso del profesor Francisco Doratioto o de Gloria da Cunha Gibbai. Un conjunto de estudiosos que está enriqueciendo nuestra cultura, al que es preciso sumar los esforzados profesores e investigadores de nuestro país, que con tantas dificultades tratan de incorporarse a la tarea, superando esa falta de metodología, de conocimientos y de medios que tradicionalmente hemos padecido. Desde mi país debemos estar orgullosos de que estas tareas puedan ser valoradas desde la inclusión y no desde la exclusión, como se ha venido realizando históricamente. En un mundo donde se presume de que la globalización debe alcanzarse en todos los ámbitos y no sólo en el económico, sería una muy importante propuesta la de crear un vínculo entre todos ellos y una organización que supiera vertebrar su empuje desde factores como la solidaridad y la comunicación entre ellos y nosotros.

La Universidad de Alicante, en España, se ha convertido en un punto de encuentro de los estudiosos paraguayos. Su buque insignia, la Biblioteca Virtual Miguel de Cervantes, ha permitido que nuestras obras existan. No ya que sean conocidas, sino que simplemente vivan y trasciendan las paupérrimas fronteras literarias de nuestro Paraguay. El portal que ha dirigido José Vicente Peiró - en La senda 
abierta por su magistral tesis - ha sabido aglutinar nuestras mejores creaciones (hasta donde los límites legales y la voluntad de los autores y herederos le han permitido). Las editoriales europeas no han sido generosas en los últimos años, pero al menos el espacio electrónico, incomprensible para muchos, nos ha dado carta de existencia. Me consta, además, que está siendo un estímulo para la creación en el país. Y ahora nos llega América sin Nombre. Es un orgullo para nosotros, un país pequeño, que una revista de literatura hispanoamericana nos otorgue un espacio. Que Alicante prosiga a este ritmo y que surjan nuevas «Alicantes».

Me siento partícipe de este esfuerzo. Quizá porque yo padecí y gocé de los terribles su- frimientos del investigador hace unas décadas. En la prehistoria surgió Alcor. Luego pusimos unas raíces en Toulouse, que se expandieron al resto de Francia. Ahora surgen brotes en otros lares. Y me resulta significativo el de España, que casi siempre había circunscrito la literatura paraguaya a un par de nombres, generalmente por su vinculación natal o cervantina. Que me hayan permitido acompañarles en este viaje por la invitación a participar en América sin Nombre, es motivo de orgullo y me ofrece el placer de pensar en que aquellos esfuerzos iniciados en los sesenta se han visto recompensados más lejos incluso de donde yo creía que llegarían a ser apreciados.

No sé si Paraguay lo agradecerá pero los paraguayos sí. 



\section{AMÉRICA SII HOMBPE}

\section{BOLETÍN DE SUSCRIPCIÓN}

Nombre

D.N.I.

Dirección

Código Postal y población

Teléfono

Derechos de suscripción: tres números (ordinarios o extraordinarios) de América sin nombre que le serán remitidos por correo a la dirección arriba detallada.

Precio: $21 €$

Forma de pago:

$\square$ Contra reembolso de cada ejemplar. (8€).

$\square$ Por talón nominativo, dirigido a Dpto. de Filología Española, Universidad de Alicante. Apartado de Correos 99 - E03080, Alicante (España). 
$$
\text { , }
$$ 





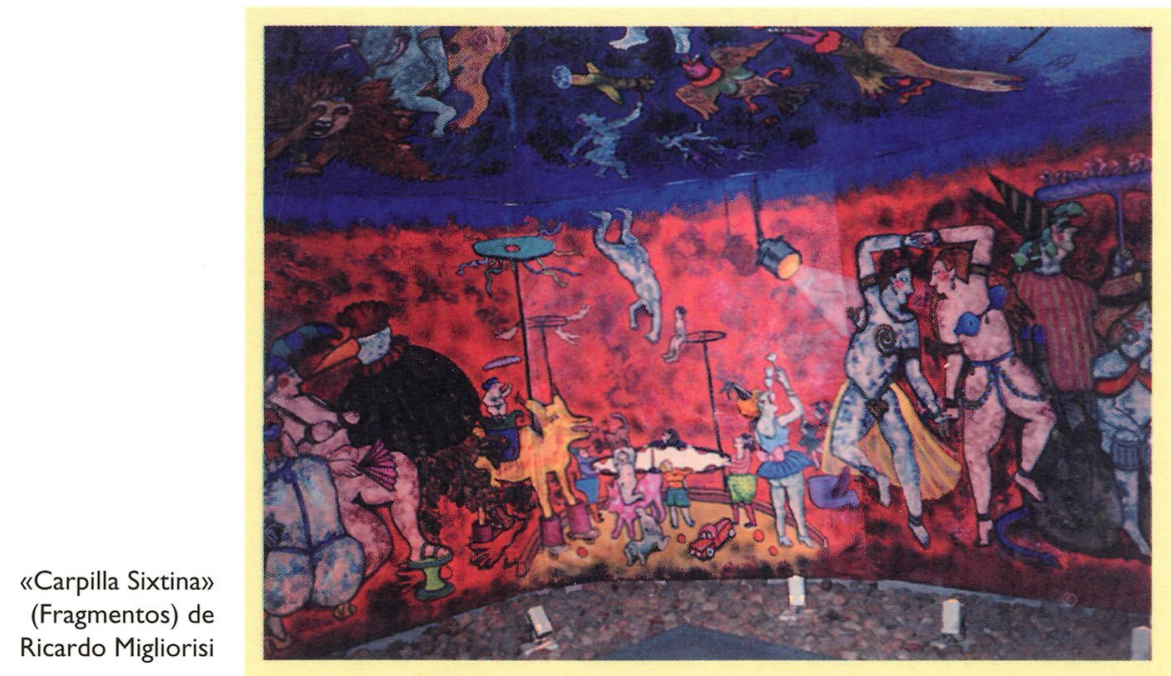

Próximo número (Diciembre 2003): MIRADAS LITERARIAS AL PASADO PREHISPÁNICO Y COLONIAL. 